ORP-56310

Revision 0

\title{
Final Report - Management of High Sulfur HLW, VSL-13R2920-1, Rev. 0, dated 10/31/2013
}

Prepared for the U.S. Department of Energy

Assistant Secretary for Environmental Management

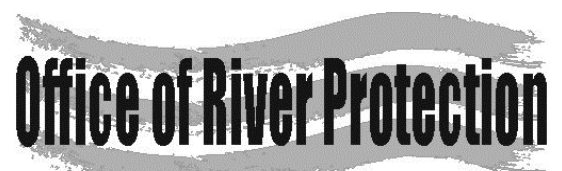

P.O. Box 450

Richland, Washington 99352 
ORP-56310

Revision 0

\section{Final Report - Management of High Sulfur HLW, VSL-13R2920-1, Rev. 0, dated 10/31/2013}

\author{
A. A. Kruger \\ Department of Energy - Office of River Protection \\ H. Gan \\ The Catholic University of America \\ I. L. Pegg \\ The Catholic University of America \\ Z. Feng \\ The Catholic University of America
}

\author{
H. Gan \\ The Catholic University of America \\ I. Joseph \\ The Catholic University of America \\ K. S. Matlack \\ The Catholic University of America
}

Prepared for the U.S. Department of Energy Assistant Secretary for Environmental Management

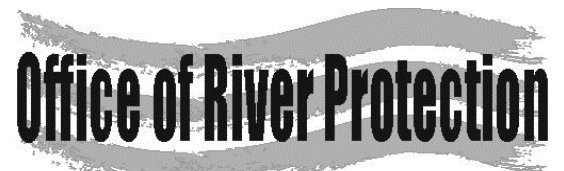

\section{P.O. Box 450}

Richland, Washington 99352

\section{APPROVED}

By Shauna Adams at 1:00 pm, Nov 13, 2013 
ORP-56310

Revision 0

TRADEMARK DISCLAIMER

Reference herein to any specific commercial product, process, or service by tradename, trademark, manufacturer, or otherwise, does not necessarily constitute or imply its endorsement, recommendation, or favoring by the United States Government or any agency thereof or its contractors or subcontractors.

This report has been reproduced from the best available copy.

Printed in the United States of America 
VSL-13R2920-1

\title{
Final Report
}

\section{Management of High Sulfur HLW}

\author{
prepared by
}

Keith S. Matlack, Wing Kot, Hao Gan, Zhijian Feng, and Ian L. Pegg

Vitreous State Laboratory

The Catholic University of America

Washington, DC 20064

$$
\text { and }
$$

Innocent Joseph

EnergySolutions, Federal EPC, Inc.

Columbia, MD 21046

for

Department of Energy

Office of River Protection

Richland, WA

September 30, 2013

Rev. 0, 10/31/13 
Document Title: $\quad$ Management of High Sulfur HLW

Document Number

and Revision: $\quad$ VSL-13R2920-1, Rev. 0

Issue Date: $\quad 10 / 31 / 13$

Performing Organization: Vitreous State Laboratory, The Catholic University of America

Test Plan: $\quad$ Management of High Sulfur HLW, VSL-12T2920-1, Rev. 0

This report describes the results of testing specified by the above Test Plan. The work was performed in compliance with the quality assurance requirements specified in the Test Plan. Results required by the Test Plan are reported. The test results and this report have been reviewed for correctness, technical adequacy, completeness, and accuracy.

I.L. Pegg:

VSL Program Director/Principal Investigator

I. Joseph: $\ln$ ocent tosebb Energy Solutions Sub-Contragt Manager
Date:

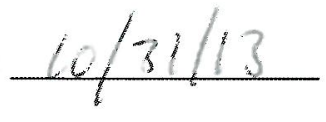

Date: $10 / 31 / 13$ 


\section{TABLE OF CONTENTS}

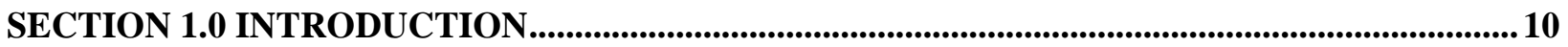

1.1 Summary OF INITIAL PHASE Of TESTING WITH HLW WASTES AND SULFUR .......................... 12

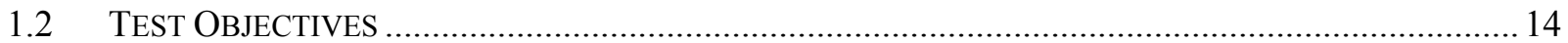

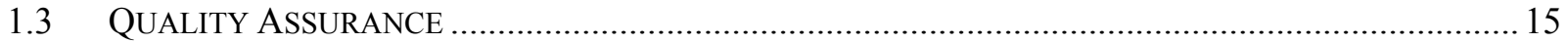

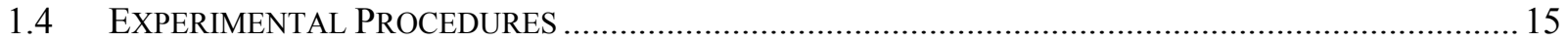

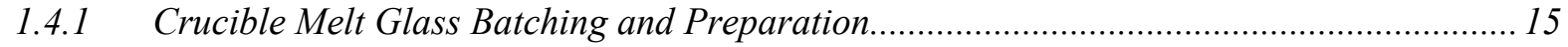

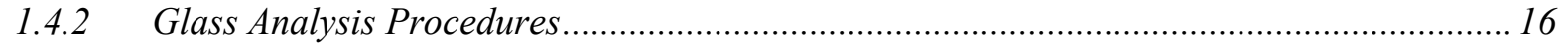

1.5 MEASUREMENTS OF SULFATE SOLUBILITY IN GLASS MELTS................................................. 18

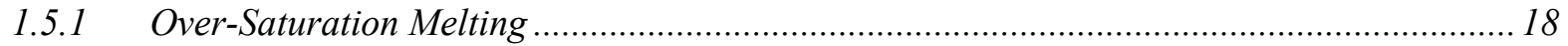

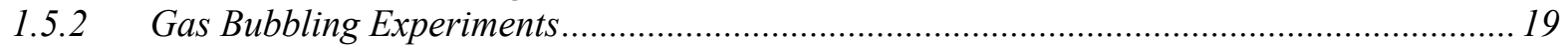

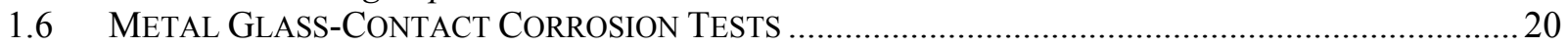

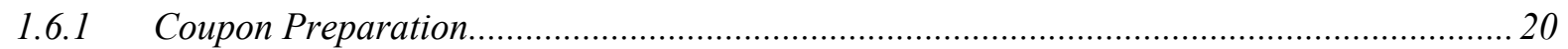

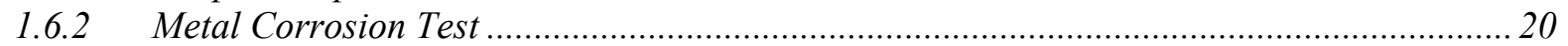

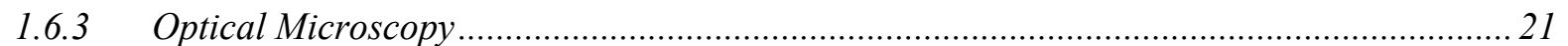

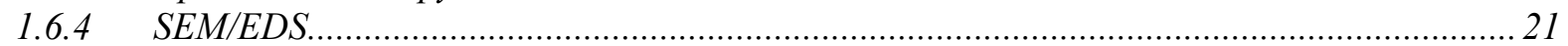

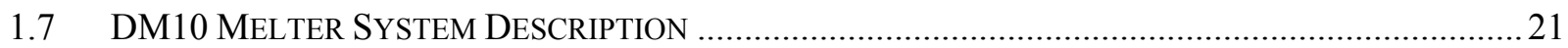

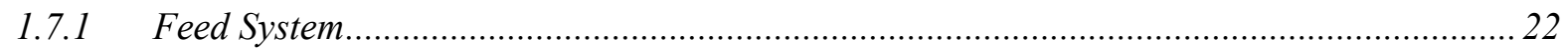

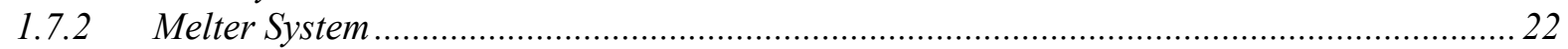

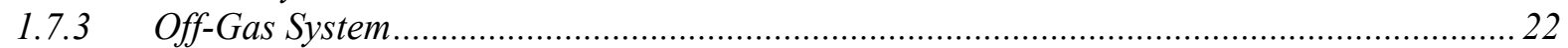

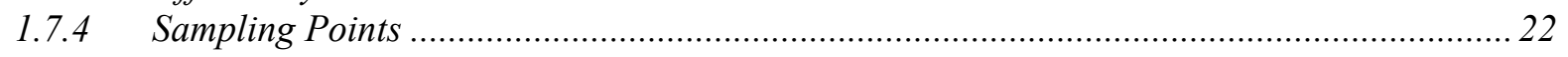

SECTION 2.0 WASTE SIMULANT AND GLASS FORMULATIONS ..............................................24

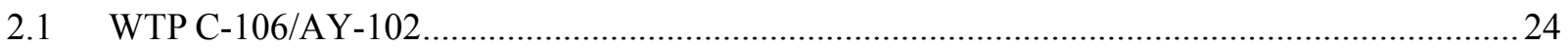

2.1.1 C-106/AY-102 Waste Simulant ........................................................................................ 24

2.1.2 C-106/AY-102 Glass Formulations and Melter Feed Formulations.................................... 25

2.2 Previously TeSted High Sulfur HLW WASte Stream [26] ............................................... 25

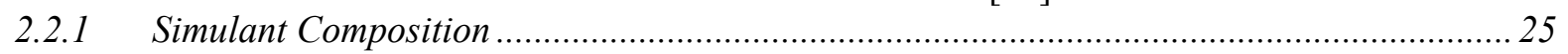

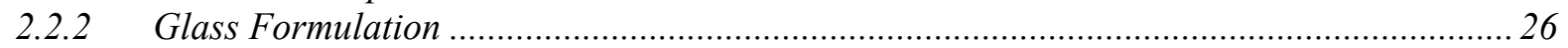

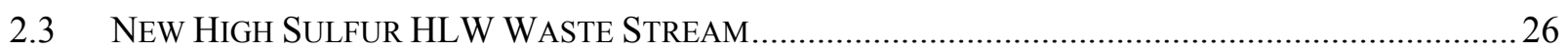

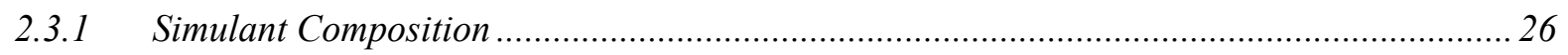

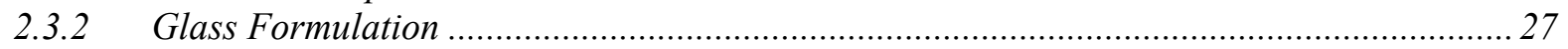

SECTION 3.0 CORROSION OF NI-CR ALLOYS IN SULFATE-BEARING HLW GLASS

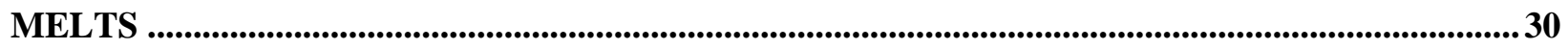

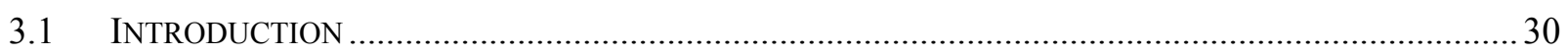

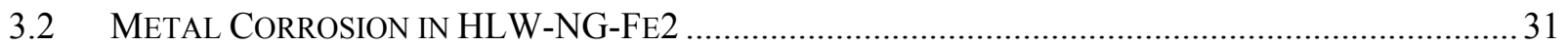

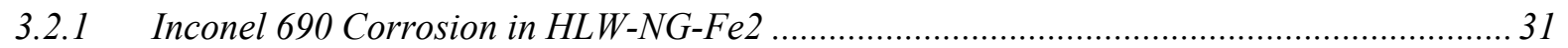

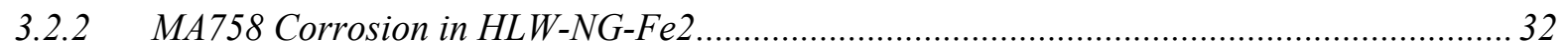

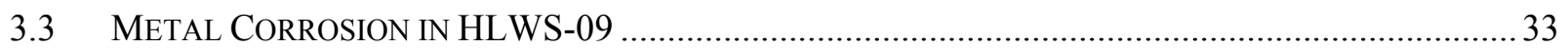

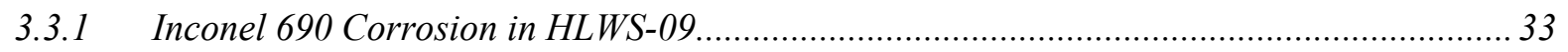

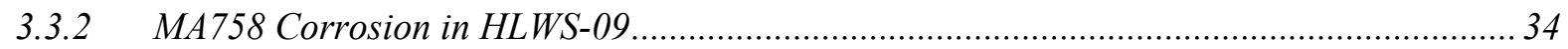

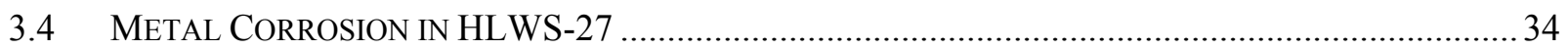

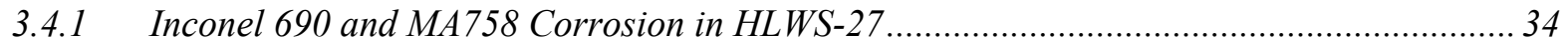

3.5 EVALUATION OF CORROSION OF INCONEL 690 AND MA758 IN S-RICH HLW GLASS .................. 35 
SECTION 4.0 MELTER OPERATIONS …................................................................................................37

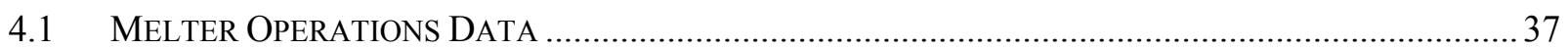

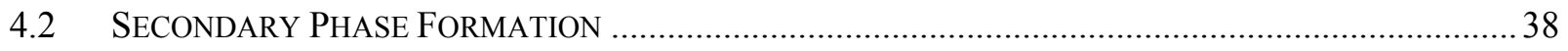

SECTION 5.0 MELTER FEED, GLASS AND EXHAUST ANALYSIS..........................................40

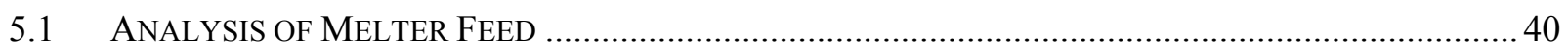

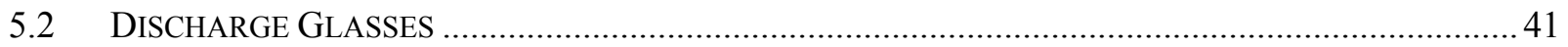

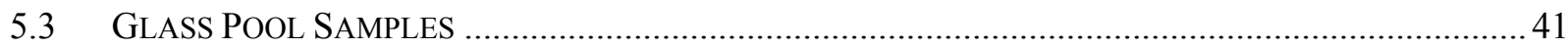

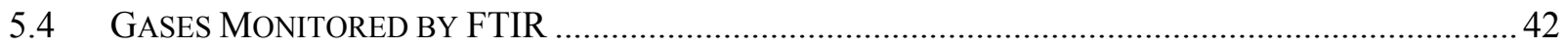

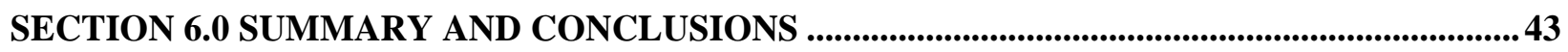

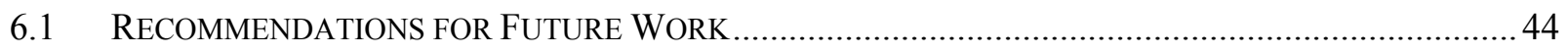

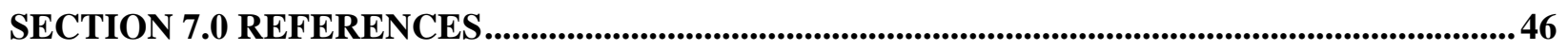




\section{List of Tables}

Table 2.1

Table 2.2

Table 2.3

Table 2.4

Table 2.5

Table 2.6

Table 2.7

Table 2.8

Table 2.9

Table 2.10

Table 2.11

Table 2.12

Table 2.13

Table 3.1

Table 3.2

Table 3.3

Table 3.4

Table 4.1

Table 5.1

Table 5.2

Table 5.3

Table 5.4

Table 5.5

Table 5.6

Table 5.7

Table 5.8

Table 5.9

Table 5.10

Table 5.11
Compositional Summary (wt\% Oxide Basis) of the C-106/AY-102 Actual Waste, AW-101 Cesium-Eluate, Blended Waste, and the High-Iron HLW Simulant.

Compositional Summary of the High-Iron HLW Simulant, Target Glass for Previous Melter Tests, and High Sulfur Glass from Melter Testing $[26,30]$. Composition (Oxide wt\%) of HLW High Sulfur Simulant. Composition of HLW Simulant to Produce $100 \mathrm{~kg}$ of Waste Oxide (21.50 wt $\%$ total solids).

Nominal Target HLWS-09 Composition and XRF Analyzed Composition for Glass Discharged (wt $\%)$. Composition (Oxide wt $\%$ ) of HLW Simulant.

$\underline{\text { Page }}$

T-1

$\mathrm{T}-2$

$\mathrm{T}-3$

$\mathrm{T}-4$

$\mathrm{T}-5$

T-6

Composition of HLW Simulant to Produce $100 \mathrm{~kg}$ of Waste Oxide (21.50 wt \% total solids).

Waste Loadings, Glass-Forming additives, and Target Compositions of High

$\mathrm{T}-7$ Sulfur HLW Glasses.

Compositions of HLWS Glasses (wt \%) Analyzed by XRF.

Characterization Data for the HLWS Series of Glasses.

$\mathrm{T}-11$

$\mathrm{T}-14$

$\mathrm{T}-18$

$\left(\mathrm{T}_{1 \%}\right)$, and the Major Crystalline Phase Near $\mathrm{T}_{1 \%}$ for the HLWS Series of Glasses.

Ranking Definition for Feed Conversion after 30 Minute VGF Test.

$\mathrm{T}-19$

TCLP Results (ppm) for Selected HLWS Glasses.

$\mathrm{T}-19$

Compositions of Three HLW Glasses for Metal Corrosion Tests $\quad$ T-20

Metal Corrosion Test Conditions. $\quad$ T-21

XRF Analysis of Glass Composition after Metal Corrosion Tests. $\quad$ T-22

Summary of Key Observations of Metal Coupons after Corrosion Test. $\quad$ T-23

Summary of DM10 Melter Tests with HLWS-27 Glass Formulation. $\quad$ T-24

$\begin{array}{ll}\text { Characteristics of Feed Samples. } & \text { T-26 }\end{array}$

$\begin{array}{ll}\text { XRF Analyzed Compositions for the Vitrified Melter Feed Samples. } & \text { T-27 }\end{array}$

List of Glass Discharged While Processing HLWS-27 Formulation. T-28

XRF Analyzed Compositions for Glass Discharged While Processing the T-31

HLWS-27 Formulation, Test A (wt\%).

XRF Analyzed Compositions for Glass Discharged While Processing the HLWS-27 Formulation, Test B (wt\%).

XRF Analyzed Compositions for Glass Discharged While Processing the HLWS-27 Formulation, Test C (wt\%).

XRF Analyzed Compositions for Glass Discharged While Processing the HLWS-27 Formulation, Test D (wt\%).

XRF Analyzed Compositions for Glass Discharged While Processing the HLWS-27 Formulation, Test E (wt\%).

$\mathrm{T}-32$

$\mathrm{T}-33$

$\mathrm{T}-34$

$\mathrm{T}-35$

List of Glass Pool Samples Taken While Processing HLWS-27 Formulation. T-36

XRF Analyzed Compositions for the Dip Samples Taken While Processing T-37

the HLWS-27 Formulation.

Concentrations [ppmv] of Selected Species in Off-Gas Measured by FTIR

Spectroscopy while Processing the HLWS-27 Formulation. 


\section{List of Figures}

Figure 1.1 Schematic diagram of a metal coupon showing typical dimensions and line $\quad$ F-1

indicating where the coupon is sectioned after testing.

Figure 1.2 Experimental set up for standard metal corrosion tests. $\quad$ F-2

Figure 1.3 DM10 melter and feed tank; off-gas system is in the background to the left. F-3

$\begin{array}{lll}\text { Figure 1.4 Schematic diagram of DM } 10 \text { vitrification system. } & \text { F-4 }\end{array}$

Figure 2.1 Sulfate solubility (as $\mathrm{wt} \% \mathrm{SO}_{3}$ ) measured by over-saturation melting and $\quad$ F-5

Figure 2.2 Comparison of sulfate solubilities (as $\mathrm{wt} \% \mathrm{SO}_{3}$ ) measured for HLWS glasses $\quad$ F-6

Figure 2.3 Measured sulfate solubilities versus $\left(\mathrm{B}_{2} \mathrm{O}_{3}+\mathrm{CaO}+\mathrm{SrO}\right)$ for current HLWS $\quad$ F-7

Figure 2.4 Scanning electron micrograph of HLWS-27 heat treated at $900^{\circ} \mathrm{C}$ and $70 \quad$ F-8

$\begin{array}{lll}\text { Figure 2.5 } & \text { Images of feed sample of HLWS-27 after vertical gradient furnace tests. } & \text { F-9 }\end{array}$

Figure 3.1(a) Sulfate loss curves from XRF analysis of HLWS-09 glass samples from $\quad$ F-10

Figure 3.1 (b) Sulfate loss curves from XRF analysis of HLW-NG-Fe2 glass samples $\quad$ F-11

Figure 3.2(a) SEM image of Inconel 690 test coupon after 7-day standard metal corrosion $\quad$ F-12 test in $\mathrm{HLW}-\mathrm{NG}-\mathrm{Fe} 2$ glass melt at $1150^{\circ} \mathrm{C}$ showing neck area.

Figure 3.2(b) SEM image of Inconel 690 test coupon after 7-day standard metal corrosion $\quad$ F-13 test in $\mathrm{HLW}-\mathrm{NG}-\mathrm{Fe} 2$ glass melt at $1150^{\circ} \mathrm{C}$ showing half-down area.

Figure 3.2(c) SEM image of Inconel 690 test coupon after 7-day standard metal corrosion $\quad$ F-14 test in $\mathrm{HLW}-\mathrm{NG}-\mathrm{Fe} 2$ glass melt at $1150^{\circ} \mathrm{C}$ showing a close-up view of half-down area.

Figure 3.2(d) SEM image of Inconel 690 test coupon after 7-day standard metal corrosion test in HLW-NG-Fe2 glass melt at $1150^{\circ} \mathrm{C}$ showing the area near the tip of the test coupon.

Figure 3.2(e) SEM image of Inconel 690 test coupon after 7-day standard metal corrosion test in HLW-NG-Fe2 glass melt at $1150^{\circ} \mathrm{C}$ showing detailed view of spinel formation near the tip of the test coupon.

Figure 3.3 Schematic diagram of the cross section of a reacted metal coupon after a typical glass contact corrosion test.

Figure 3.4 Concentration profiles of $\mathrm{Cr}$ in Inconel 690 test coupon by SEM/EDS after 7-day standard metal corrosion test in HLW-NG-Fe2 at $1150^{\circ} \mathrm{C}$.

Figure 3.5(a) SEM image of MA758 test coupon after 7-day standard metal corrosion test in HLW-NG-Fe 2 glass melt at $1150^{\circ} \mathrm{C}$ showing the neck area.

Figure 3.5(b) SEM image of MA758 test coupon after 7-day standard metal corrosion test in

Figure 3.5(c) SEM image of MA758 test coupon after 7-day standard metal corrosion test in $\mathrm{HLW}-\mathrm{NG}-\mathrm{Fe} 2$ glass melt at $1150^{\circ} \mathrm{C}$ showing a close up view of the half-down area.

Figure 3.5(d) SEM images of MA758 test coupon after 7-day standard metal corrosion test in $\mathrm{HLW}-\mathrm{NG}-\mathrm{Fe} 2$ glass melt at $1150^{\circ} \mathrm{C}$ showing the tip of the test coupon.

Figure 3.6 Concentration profiles of $\mathrm{Cr}$ in MA758 test coupon by SEM/EDS after

F-20 7-day standard metal corrosion test in HLW-NG-Fe2 at $1150^{\circ} \mathrm{C}$. 
Figure 3.7(a) SEM image of Inconel 690 test coupon after 7-day standard metal corrosion

F-22

test (open to air) in HLWS-09 at $1150^{\circ} \mathrm{C}$ showing the neck area.

Figure 3.7(b) SEM image of Inconel 690 test coupon after 7-day standard metal corrosion $\quad$ F-22 test (open to air) in HLWS-09 at $1150^{\circ} \mathrm{C}$ showing half-down area.

Figure 3.7(c) SEM image of Inconel 690 test coupon after 7-day standard metal corrosion $\quad$ F-23 test (open to air) in HLWS-09 at $1150^{\circ} \mathrm{C}$ showing close up view of half-down area.

Figure 3.7(d) SEM image of Inconel 690 test coupons after 7-day standard metal corrosion $\quad$ F-23 test (open to air) in HLWS-09 at $1150^{\circ} \mathrm{C}$ showing tip of test coupon.

Figure 3.7(e) SEM image of Inconel 690 test coupon after 7-day standard metal corrosion

F-24 test (open to air) in HLWS-09 at $1150^{\circ} \mathrm{C}$ showing close up view of tip of test coupon.

Figure 3.8(a) SEM image of Inconel 690 after 7-day sealed metal corrosion test in HLWS-09 at $1150^{\circ} \mathrm{C}$ showing neck area (sealed crucible test).

Figure 3.8(b) SEM image of Inconel 690 after 7-day sealed metal corrosion test in HLWS-09 at $1150^{\circ} \mathrm{C}$ showing half-down area (sealed crucible test).

Figure 3.8(c) SEM image of Inconel 690 after 7-day sealed metal corrosion test in HLWS-09 at $1150^{\circ} \mathrm{C}$ showing close up view of I half-down area.

Figure 3.8(d) SEM image of Inconel 690 after 7-day sealed metal corrosion test in HLWS-09 at $1150^{\circ} \mathrm{C}$ showing the tip of the metal coupon (sealed crucible test).

Figure 3.8(e) SEM image of Inconel 690 after 7-day sealed metal corrosion test in HLWS-09 at $1150^{\circ} \mathrm{C}$ showing a close up view of the tip of the metal coupon (sealed crucible test).

Figure 3.9 Concentration profiles of $\mathrm{Cr}$ in Inconel 690 after a 7-day corrosion test in

F-28 HLWS-09 test.

Figure 3.10 SEM/EDS analysis of $\mathrm{Cr}$ in Inconel 690 after 7-day corrosion test in

F-30 HLWS-09 in standard open crucible condition (filled magenta squares) and in sealed crucible condition (filled black triangles).

Figure 3.11(a) SEM image of MA758 after 7-day standard open crucible corrosion test in HLWS-09 at $1150^{\circ} \mathrm{C}$ showing the neck area.

Figure 3.11(b) SEM image of MA758 after 7-day standard open crucible corrosion test in HLWS-09 at $1150^{\circ} \mathrm{C}$ showing a close up view of the neck area.

Figure 3.11(c) SEM image of MA758 after 7-day standard open crucible corrosion test in HLWS-09 at $1150^{\circ} \mathrm{C}$ showing the half-down area.

Figure 3.11(d) SEM image of MA758 after 7-day standard open crucible corrosion test in HLWS-09 at $1150^{\circ} \mathrm{C}$ showing a close up view of the half-down area.

Figure 3.11(e) SEM image of MA758 after 7-day standard open crucible corrosion test in HLWS-09 at $1150^{\circ} \mathrm{C}$ showing the tip of the test coupon.

Figure 3.12(a) SEM image of MA758 after 7-day sealed crucible test in HLWS-09 at $1150^{\circ} \mathrm{C}$ showing the neck area

Figure 3.12(b) SEM image of MA758 after 7-day sealed crucible test in HLWS-09 at $1150^{\circ} \mathrm{C}$ showing the half-down area.

Figure 3.12(c) SEM image of MA758 after 7-day sealed crucible test in HLWS-09 at $1150^{\circ} \mathrm{C}$ showing close up view of the half-down area.

Figure 3.12(d) SEM image of MA758 after 7-day sealed crucible test in HLWS-09 at $1150^{\circ} \mathrm{C}$ showing a detailed view of the half-down area.

Figure 3.12(e) SEM image of MA758 after 7-day sealed crucible test in HLWS-09 at $1150^{\circ} \mathrm{C}$ showing the tip of the test coupon. 
Figure 3.13 SEM/EDS analysis of Cr in MA758 after 7-day test in HLWS-09 at $1150^{\circ} \mathrm{C}$.

Figure 3.14 Comparison of Cr depletion at half-down areas of MA758 after 7-day corrosion tests in HLWS-09 in the standard open crucible (black triangles) and in the sealed crucible (magenta squares).

Figure 3.15 SEM images of Inconel690 after 7-day sealed crucible test at $1150^{\circ} \mathrm{C}$ in HLWS-27.

Figure 3.16 SEM images of MA758 after 7-day sealed crucible corrosion test in $\quad$ F-45

$\begin{array}{ll}\mathrm{HLWS}-27 \text { at } 1150^{\circ} \mathrm{C} \text {. } \\ \text { Figure 3.17 } & \mathrm{SEM} / \mathrm{EDS} \text { analysis of Cr depletion near surface of Inconel } 690 \text { after 7-day }\end{array}$ sealed crucible corrosion test in HLWS-27 at $1150^{\circ} \mathrm{C}$.

Figure 3.18 SEM/EDS analysis of Cr depletion near surface of MA758 after 7-day $\quad$ F-50

Figure 3.19 Comparison of Cr depletion at half-down areas after 7-day corrosion tests $\quad$ F-51 in HLWS-27 in sealed crucibles for MA758 (black triangles) and for Inconel 690 (magenta squares).

Figure 4.1 XRF measured product and target glass sulfur concentrations while processing the HLWS-27 glass formulation.

Figure 5.1 XRF measured product and target glass soda and silica concentrations.

Figure 5.2 XRF measured product and target glass aluminum and manganese oxide concentrations.

Figure 5.3 XRF measured product and target glass calcium and iron oxide $\quad$ F-55 concentrations.

Figure 5.4 XRF measured product and target glass bismuth and nickel oxide $\quad$ F-56 concentrations.

$\begin{array}{lll}\text { Figure 5.5 XRF measured product and target glass phosphorus and strontium oxide } & \text { F-57 }\end{array}$ concentrations.

Figure 5.6(a) Secondary phase observed on dip sample, D-10B-67C, taken after Test 2D. F-58 Figure 5.6(b) Secondary phase observed on dip sample, D-10B-67C, taken after Test 2D. F-59 


\section{List of Abbreviations}

$\begin{array}{ll}\text { ANL-LRM } & \text { Argonne National Laboratory-Low-Activity Waste Reference Material } \\ \text { ASME } & \text { American Society of Mechanical Engineers } \\ \text { BDAT } & \text { Best Demonstrated Available Technology } \\ \text { BNI } & \text { Bechtel National, Inc. } \\ \text { CCC } & \text { Canister Centerline Cooling } \\ \text { CEM } & \text { Continuous Emissions Monitoring } \\ \text { DCP-AES } & \text { Direct Current Plasma - Atomic Emission Spectroscopy } \\ \text { DM } & \text { DuraMelter } \\ \text { DOE } & \text { Department of Energy } \\ \text { DWPF-EA } & \text { Defense Waste Processing Facility-Environmental Assessment } \\ \text { EPA } & \text { Environmental Protection Agency } \\ \text { FTIR } & \text { Fourier Transform Infrared Spectroscopy } \\ \text { HEPA } & \text { High-Efficiency Particulate Air Filter } \\ \text { HLW } & \text { High Level Waste } \\ \text { HTWOS } & \text { Hanford Tank Waste Operations Simulator } \\ \text { IC } & \text { Ion Chromatography } \\ \text { LAW } & \text { Low Activity Waste } \\ \text { NIST } & \text { National Institute of Standards and Technology } \\ \text { NQA } & \text { Nuclear Quality Assurance } \\ \text { ORP } & \text { Office of River Protection } \\ \text { PCT } & \text { Product Consistency Test } \\ \text { PNNL } & \text { Pacific Northwest National Laboratory } \\ \text { PVC } & \text { Polyvinyl Chloride } \\ \text { QARD } & \text { Quality Assurance Requirements and Description } \\ \text { RCRA } & \text { Resource Conservation and Recovery Act } \\ \text { SEM/EDS } & \text { Scanning Electron Microscopy/Energy Dispersive X-ray Spectroscopy } \\ \text { SOP } & \text { Standard Operating Procedure } \\ \text { SRNL } & \text { Savannah River National Laboratory } \\ \text { TCLP } & \text { Toxicity Characteristic Leaching Procedure } \\ \text { TFCOUP } & \text { Tank Farm Contractor Operation and Utilization Plan } \\ \text { UTS } & \text { Universal Treatment Standard } \\ \text { VGF } & \text { Vertical Gradient Furnace } \\ \text { VSL } & \text { Vitreous State Laboratory } \\ \text { WTP } & \text { Waste Treatment and Immobilization Plant } \\ \text { XRF } & \text { X-ray Fluorescence Spectroscopy } \\ & \\ & \end{array}$




\section{SECTION 1.0 INTRODUCTION}

Wastes that are stored in underground tanks at the Hanford site contain significant amounts of sulfate. Treatment of these wastes at the Hanford Tank Waste Treatment and Immobilization Plant (WTP) will involve separation into Low Activity Waste (LAW) and High Level Waste (HLW) fractions followed by vitrification of these streams to produce LAW and HLW glasses. It is expected that much of the sulfate in the tank wastes is water soluble and, therefore, it should report primarily to the LAW stream. The sulfate content in the LAW feeds is projected to be sufficiently high that a separate molten sulfate salt phase may form on top of the glass melt during the vitrification process unless suitable glass formulations are employed and sulfate levels are controlled. Since the formation of the salt phase is undesirable from many perspectives, mitigation approaches had to be developed. Considerable progress has been made and reported by the Vitreous State Laboratory (VSL) in enhancing sulfate incorporation into LAW glass melts and developing strategies to manage and mitigate the risks associated with high-sulfate LAW feeds [1-6].

In contrast, little work has been performed on HLW glasses to investigate the behavior of sulfate during vitrification. HLW glass development for the WTP until recently has assumed low levels of sulfate in the glass $(<0.5 \mathrm{wt} \%)$. At such low levels, secondary sulfate salt formation is generally not a significant issue and, therefore, little effort was directed at improving sulfate loading in HLW glasses. However, pretreatment tests have indicated that sufficient interstitial liquid with high enough sulfate concentration can be carried over to HLW during the HLW/LAW separation process to increase sulfate content in HLW feeds to levels at which secondary sulfate phase formation may become an issue. In addition, the levels of insoluble sulfate compounds, which would be carried over with the HLW solids, are uncertain. Furthermore, the Office of River Protection (ORP) System Plan projections frequently show a large fraction of the HLW batches being limited by sulfate. In addition, recent plans for direct feeding of HLW to the WTP vitrification facility with minimal pretreatment will result in higher sulfate concentrations in the feeds. Preliminary tests on baseline WTP HLW glasses have shown that sulfate loadings need to be kept fairly low (about $0.5 \mathrm{wt} \%$ or less) to avoid sulfate phase formation in these glasses. As with LAW glasses, the molten salt phases that form are highly electrically conductive, have low viscosity and low melting points, are highly corrosive, incorporate various radionuclide and hazardous elements, and are water soluble. Consequently, formation of a secondary sulfate phase can result in many deleterious effects such as increased corrosion of metallic components, reduced melter lifetime, degraded melter performance, product quality issues, etc. The majority of the experience to-date in this area has been with LAW streams since relatively little emphasis has been previously placed on sulfur in HLW streams. For LAW, the impact of high sulfate levels with respect to increased corrosion of metallic components such as bubblers, thermowells, level detectors, etc., has been recognized [710] and addressed through design changes. Thus, WTP LAW bubblers are specifically designed to operate in glass melt environment that is more corrosive [7, 11]. In contrast, the effects of high sulfur HLW melts have not been considered in the design of the HLW bubblers [12]. Because of 
these design differences, with higher levels of sulfate in the HLW feeds a particular concern will be accelerated corrosion of HLW bubblers. Furthermore, sulfate salt phases are easily leachable (much more so than glass) and they typically incorporate high concentrations of components such as $\mathrm{Ba}, \mathrm{Cr}, \mathrm{Cs}$ and Tc $[8,9,11]$. Therefore, the presence of sulfate salts in the HLW product could constitute a significant product quality issue. A substantial amount of work has been completed on Hanford LAW glasses to improve sulfate loading and it is anticipated that many of the same approaches can be used to improve sulfate loading in Hanford HLW glasses.

Based on early Bechtel National, Inc. (BNI) WTP flow-sheet projections, the concentration of sulfate in the feed to the HLW vitrification facility were relatively low in most of the testing program that was performed to support the development of the present WTP HLW baseline. As a result, sulfate was not expected to be a significant component that would limit waste loading. Later process models suggested that sulfate concentrations in HLW glasses could likely exceed the highest concentrations tested in HLW crucible melts, and exceed values tested in scaled melter runs that showed segregated salt layers [13]. This is also reflected in more recent assessments, and particularly those performed for WTP system planning, which show that sulfate could indeed limit waste loadings in a significant fraction of the HLW feeds over the WTP mission. Based on the initial expectations, the concentrations of sulfate tested in both HLW crucible melts and melter tests were low, such that the maximum sulfate concentration in HLW glasses formulated to support melter tests was only $0.13 \mathrm{wt} \%$ (as $\mathrm{SO}_{3}$ in the glass product) [14]. Subsequently, melter tests were performed with an HLW glass formulated to support actual waste testing with a target $\mathrm{SO}_{3}$ concentration of $0.19 \mathrm{wt} \%[15,16]$, whereas HLW matrix glasses, designed to cover a much wider glass compositional region, contain a maximum of only $0.28 \mathrm{wt} \%$ of $\mathrm{SO}_{3}[17]$.

In view of the very limited information on the likely range of sulfate solubilities in typical HLW glass melts, under the BNI WTP test program, twenty HLW glasses were selected to provide representative coverage of the expected compositional range of glasses to be produced at the WTP [18]. All of the selected glasses were previously formulated and characterized to support various tasks including melter testing, actual waste testing, property-composition model development, and support of HLW glass algorithm development. The solubility of sulfate in these glasses was measured by saturation with $\mathrm{SO}_{3}$ by continuous gas bubbling. The measured sulfate solubilities ( $\mathrm{SO}_{3}$ in glass) ranged from $0.53 \mathrm{wt} \%$ to $1.60 \mathrm{wt} \%$, with a median of $0.64 \mathrm{wt} \%$. Two of these HLW glasses were processed on the DM10 melter system at VSL at successively higher sulfate concentrations until secondary phases were observed [19]. In one of those tests, the amount of sulfur contained in the glass upon the formation of secondary phases matched the amount determined in the bubbling experiments, while the other melter test produced a glass with about half the amount of sulfur as compared to the bubbling experiments. This difference indicates that sulfur solubility is not the only factor influencing the amount of sulfur that can be processed without the formation of deleterious secondary phases.

As part of the work performed at VSL for ORP, new glass formulations with waste streams containing variable amounts of sulfur were developed to extend composition spaces beyond those that have been previously investigated for the WTP [20]. The work was performed with four waste compositions specified by ORP [21]; these wastes contain high concentrations of bismuth, chromium, aluminum, and aluminum plus sodium. The tests were designed to identify 
glass formulations that maximize waste loading while meeting all processing and product quality requirements. The high-chromium waste was also high in sulfur, which in turn limited the waste loading to $32.5 \mathrm{wt} \%$ with a sulfur concentration in the product glass of $0.45 \mathrm{wt} \%$ of $\mathrm{SO}_{3}$ [20]. Subsequently, the glass composition for this waste stream was reformulated, allowing the waste loading to be increased to $45 \mathrm{wt} \%$ [22]. Glasses formulated for the high bismuth waste targeted $0.48 \mathrm{wt} \%$ of $\mathrm{SO}_{3}$ at $50 \%$ waste loading and were processed on both the DM100 and DM1200 melter systems without the formation of any secondary sulfur phases [20, 23]. Taken together, these tests show the wide range in potential sulfur concentrations in projected HLW streams, the effect of the waste and glass composition on the formation of secondary sulfur phases, and the potential to mitigate the formation of secondary sulfur phases through manipulation of the glass formulation and glass forming additives.

The present report describes results from a series of small-scale crucible tests to determine the extent of corrosion associated with sulfur containing HLW glasses and to develop a glass composition for a sulfur-rich HLW waste stream, which was then subjected to small-scale melter testing to determine the maximum acceptable sulfate loadings. This work was performed in accordance with a contract with ORP [24] and the Test Plan for this work [25]. This work builds on previous work for ORP to develop and test new glass formulations for projected high sulfur HLW streams [26, 27]. Both of these test series were preceded by a review of previously conducted tests with sulfur as a constituent in WTP HLW and LAW wastes. Sulfur solubility information is compiled in a previous report to WTP for HLW glasses [18] and in a previous report to ORP for LAW glasses [28]. In the present work, a new glass formulation was developed and tested for a projected Hanford HLW composition with sulfate concentrations high enough to limit waste loading. Testing was then performed on the DM10 melter system at successively higher waste loadings to determine the maximum waste loading without the formation of a separate sulfate salt phase. Small scale corrosion testing was also conducted using the glass developed in the present work, the glass developed in the initial phase of this work [26], and a high iron composition, all at maximum sulfur concentrations determined from melter testing, in order to assess the extent of Inconel 690 and MA758 corrosion at elevated sulfate contents.

\subsection{Summary of Initial Phase of Testing with HLW Wastes and Sulfur}

In previous work, tests were conducted at the crucible scale and on the DM10 melter to measure sulfur solubility and maximum feed sulfur concentrations that can be processed without the formation of secondary sulfate phases for a range of HLW glass compositions, as well as the sulfur solubility and maximum waste loading for a projected high sulfur HLW stream [26]. High iron WTP glass compositions for HLW streams from C-106/AY-102 [16, 29, 30], AZ-101 [22, $31]$ and AZ-102 [16, 32], as well as glasses formulated with waste streams containing high concentrations of bismuth, chromium, aluminum, and aluminum plus sodium [20,33, 34] were tested at either the crucible scale or in the DM10 melter. Sulfur solubility in HLW glasses was measured by two different methods at crucible scale (over-batching and gas bubbling) and by processing of HLW feeds at various sulfur contents on the DM10 melter system. 
A glass composition (HLWS-09) was formulated for a projected high sulfur HLW stream with a nominal waste loading of $28 \mathrm{wt} \%$ and a target sulfur concentration of $1.20 \mathrm{wt} \% \mathrm{SO}_{3}$. A variety of additive blends were tested to identify a glass with the highest sulfur solubility while meeting all processing and product quality requirements for WTP HLW glass. Subsequent melter testing showed that this formulation showed no sulfate salt formation even at a waste loading of $38 \mathrm{wt} \%$ or at a target sulfur concentration of $1.91 \mathrm{wt} \% \mathrm{SO}_{3}$.

Glass melts were bubbled with gas mixtures that include sulfur to determine the solubility of sulfur in the glass using a procedure previously used with HLW and LAW glasses [18, 35]. The sulfur solubility was measured for four glasses formulated with Hanford HLW high-iron streams and four glasses formulated with waste streams containing high concentrations of bismuth, chromium, aluminum, and aluminum plus sodium specified by ORP. These results were compared to a variety of other glasses subjected to the same sulfur solubility measurement procedure to discern trends in sulfur solubility with glass composition. Despite the difficulty in detecting trends in multi-element glasses, sulfur solubility does appear to increase with increasing alkaline earth elements and boron concentrations. The association of alkali and sulfur solubility appears to be much weaker in the HLW glasses studied, in contrast to LAW glasses where $\mathrm{Li}_{2} \mathrm{O}$ was beneficial in improving sulfate solubility. The measured sulfur solubility for glasses formulated with both high iron and high aluminum wastes demonstrate that sulfur solubility can be increased through changes in glass formulation while maintaining other properties within acceptable ranges.

Melter tests were conducted with three different HLW simulants and associated glass formulations at various feed sulfur concentrations on the DM10 melter. The highest sulfur feed concentrations and waste loadings that could be processed through the DM10 without the formation of secondary sulfate phases were determined. These tests produced over $360 \mathrm{~kg}$ of glass from over a metric ton of feed formulated for three different HLW streams: a C-106/AY-102 high iron composition, an ORP defined high aluminum composition, and a projected high sulfur stream. In each of the eighteen tests, the bubbling rate was adjusted to achieve a feed rate of $3 \mathrm{~kg} / \mathrm{hr}$ (about $1300 \mathrm{~kg} / \mathrm{m}^{2} /$ day), a near-complete cold cap, and a target plenum temperature of $550-650^{\circ} \mathrm{C}$. Glass samples taken throughout the tests from the melt pool and the air-lift discharge were visually examined for secondary phases and analyzed for chemical composition. Glass samples were taken from the melt pool to detect secondary phases on the melt pool surface. Results for the three glass compositions are summarized as follows:

HWI-Al-19 (high aluminum waste): The sulfur content of the feed was progressively increased to $1.3 \mathrm{wt} \% \mathrm{SO}_{3}$ on a glass basis, and a measured $\mathrm{SO}_{3}$ content of $0.8 \mathrm{wt} \%$ in the glass product, without any observations of secondary sulfur phases. Testing at higher feed and glass sulfur levels resulted in the formation of secondary phases. Therefore the processing limits for sulfur content appears to be 1.3 and $0.8 \mathrm{wt} \% \mathrm{SO}_{3}$ for the feed and glass, respectively, which is significantly less than the $1.25 \mathrm{wt} \% \mathrm{SO}_{3}$ saturation level for glass measured in the crucible-scale bubbling tests.

HLW-NG-Fe2 (high iron waste): The sulfur content of the feed was decreased progressively from 0.7 to $0.6,0.5$, and $0.4 \mathrm{wt} \% \mathrm{SO}_{3}$ on a glass basis with numerous observations of secondary sulfur phases at the two highest sulfur concentrations and little or no observations 
of secondary phase at the lower concentrations. The test results indicate that the limiting feed sulfur concentration is about $0.5 \mathrm{wt} \% \mathrm{SO}_{3}$ and the associated level of sulfur in the glass is about $0.35 \mathrm{wt} \% \mathrm{SO}_{3}$, which is significantly less than the $0.83 \mathrm{wt} \% \mathrm{SO}_{3}$ saturation level measured in the crucible-scale bubbling tests.

HLWS-09 (high sulfur waste): The sulfur content of the feed was adjusted both by increasing the ratio of the sulfur-containing waste to the additives and by adding sulfuric acid to the nominal feed composition. The feed concentration of sulfur was increased to $1.63 \mathrm{wt} \% \mathrm{SO}_{3}$ at $38 \%$ waste loading and $1.91 \mathrm{wt}^{\mathrm{t}} \mathrm{\textrm {SO } _ { 3 }}$ at the nominal waste loading without the formation of secondary sulfate phases. The concentration of sulfur in the glass increased to $1.2 \mathrm{wt} \% \mathrm{SO}_{3}$ at the high waste loading and $1.6 \mathrm{wt} \% \mathrm{SO}_{3}$ at the nominal waste loading. Thus, the limit for sulfur in the glass is greater than $1.6 \mathrm{wt} \% \mathrm{SO}_{3}$, which is consistent with the $1.78 \mathrm{wt} \% \mathrm{SO}_{3}$ saturation level measured in the crucible-scale bubbling tests. This glass composition was also shown to be robust with respect to formation of secondary phases resulting from changes in glass composition due to changes in waste loading. The very high sulfur tolerance of this formulation, which rivals that of the best LAW formulations, is noteworthy, particularly in comparison to the present ORP System Plan 6 limit of $0.5 \mathrm{wt} \% \mathrm{SO}_{3}$ [36] and the WTP limit of $0.44 \mathrm{wt} \% \mathrm{SO}_{3}$ [37] for HLW glass.

\subsection{Test Objectives}

The principal objectives of the present crucible scale and DM10 tests were to measure sulfur solubility and maximum feed sulfur concentrations that can be processed without the formation of secondary sulfate phases for a different projected high sulfur HLW stream. A further objective was to measure Inconel 690 and MA758 corrosion on a high iron WTP glass composition for C-106/AY-102 HLW [26, 30] and on glasses formulated for each of the two high sulfur HLW compositions $[25,26,36]$ that were processed in DM10 melter tests.

Specific objectives of these tests were to:

- Measure the extent of Inconel 690 and MA758 corrosion from glasses formulated with a Hanford HLW high-iron stream and two glasses formulated with waste streams containing high concentrations of sulfur $[25,26,36]$ at the highest sulfur concentration observed not to form secondary sulfur phases.

- Formulate a glass composition for a projected high sulfur HLW stream and investigate the maximum achievable waste loading.

- Determine the maximum waste loading that can be processed on the DM10 without the formation of secondary phases for a projected high sulfur HLW stream.

- Characterize the chemical composition of each glass discharged from the DM10 with particular emphasis on sulfur. 
- Monitor off-gas constituents from the DM10 ( $\left.\mathrm{N}_{2} \mathrm{O}, \mathrm{NO}, \mathrm{NO}_{2}, \mathrm{NH}_{3}, \mathrm{CO}_{2}, \mathrm{CO}, \mathrm{SO}_{2}\right)$ by Fourier Transform Infrared Spectroscopy (FTIR).

To meet these objectives, the following tests were performed:

- Glasses from melter tests [26] underwent corrosion testing with coupons of Inconel 690 and MA758 using a procedure previously used with WTP glasses [8-12];

- Glass compositions were formulated for a projected high sulfur HLW waste stream and characterized; and

- The highest sulfur feed concentrations and waste loadings that can be processed through the DM10 without the formation of secondary sulfate phases was determined.

The DM10 melter system has been used for a range of tests with HLW glass compositions investigating production rate, increases in waste loading, volatile retention, and the tendency to form secondary phases $[19,20,22,26,31,38]$. For the present work, sufficient simulated HLW feed was produced to conduct a total of 80 hours of DM10 testing.

\subsection{Quality Assurance}

Testing was performed according to the existing quality assurance program that is in place at VSL. That program is compliant with applicable criteria of 10 CFR 830.120; Office of Civilian Waste Management DOE/RW-0333P, Quality Assurance Requirements and Description (QARD) Revision 20; the American Society of Mechanical Engineers (ASME) NQA-1, 2004; and DOE Order 414.1 C, Quality Assurance. The requirements of DOE/RW-0333P are applicable to the following specific aspects of this work:

- Crucible melt preparation of HLW glasses

- Analysis of HLW crucible melt glasses

- $\quad$ PCT of HLW glasses

The program is supplemented by a Quality Assurance Project Plan for ORP work [39] that is conducted at VSL. Test and procedure requirements by which the testing activities are planned and controlled are also defined in this plan. The program is supported by VSL standard operating procedures that were used for this work [40].

\subsection{Experimental Procedures}

\subsubsection{Crucible Melt Glass Batching and Preparation}

HLW glasses are fabricated at the crucible scale using reagent grade chemicals in 
accordance with VSL standard operating procedures (SOPs) [40]. The following briefly summarizes the procedural steps.

Glass preparation begins with a batching sheet that provides information on the required starting materials. The information includes the chemicals needed, identification of the chemicals according to the vendors and catalog numbers, the associated purity, together with the quantity required to produce a given amount of glass. The quantities of chemicals required are adjusted based on the reagent purities. Chemicals are weighed and batched according to the batching sheets.

After the starting materials are weighed and batched, a blender is used to mix and homogenize the starting materials before they are loaded into platinum alloy crucibles that are engraved with individual identification numbers. The loaded platinum/gold crucible is placed inside a Deltech DT-28 (or DT-29) furnace, the heating of which is controlled by a Eurotherm 2404 temperature controller. The melting temperature is $1150^{\circ} \mathrm{C}$, at which the melt is kept for 2 hours. Mixing of the melt is accomplished mechanically using a platinum stirrer, beginning 20 minutes after the furnace temperature reaches $1150^{\circ} \mathrm{C}$ and continuing for the next 90 minutes. The molten glass is poured at the end of 120 minutes onto a graphite plate to cool before recovery.

\subsubsection{Glass Analysis Procedures}

\subsubsection{Composition}

With the exception of the lightest elements (i.e., boron and lithium), all glass components including $\mathrm{SO}_{3}$ are measured by X-ray fluorescence spectroscopy (XRF). Test glasses are powdered to give -200 mesh samples before analysis with a PANalytical Axios mAX-Advanced wavelength dispersive XRF spectrometer. The XRF is calibrated over a range of glass compositions using standard reference materials traceable to National Institute of Standards and Technology (NIST) as well as other glasses, including the Argonne National Laboratory-LowActivity Waste Reference Material (ANL-LRM), Defense Waste Processing Facility-Environmental Assessment (DWPF-EA) glass, West Valley Reference 6 glass, and WTP HLW and LAW glasses.

The analysis of sulfate salts is performed with direct current plasma - atomic emission spectroscopy (DCP-AES) and ion chromatography (IC). Samples of the sulfate phases removed from saturated glass samples are subjected to microwave assisted total acid dissolution in Teflon vessels according to VSL standard operating procedures. Twenty milliliters of a 1:5 mixture of concentrated $\mathrm{HF}: \mathrm{HNO}_{3}$ is diluted to $50 \mathrm{ml}$ for use in dissolution. The sample solution is analyzed by DCP-AES. Sulfate in the solution is measured by IC (Dionex DX-120 and IonPac AS14) and reported as $\mathrm{SO}_{3}$. 


\subsubsection{Viscosity}

The viscosity of the glass melt, $\eta$, is measured using a Brookfield viscometer per VSL SOPs [40]. The viscosity is determined from the relation between torque and rotation speed of the spindle in the glass melt. Measurements are normally performed in the temperature range of $950^{\circ} \mathrm{C}$ to $1250^{\circ} \mathrm{C}$ and the data are interpolated to standard temperatures using the Vogel-Fulcher equation:

$$
\ln \eta=\left[A /\left(T-T_{o}\right)\right]+C
$$

where $A, C$, and $T_{o}$ are fitting parameters. The equipment is calibrated at room temperature using standard oils of known viscosity and then checked from $950^{\circ} \mathrm{C}$ to $1250^{\circ} \mathrm{C}$ using a NIST standard reference glass (SRM 711). Both precision and accuracy of the viscosity measurement are estimated to be within \pm 15 relative $\%$.

\subsubsection{Electrical Conductivity}

The electrical conductivity, $\sigma$, is determined, according to VSL SOPs [40], by measuring the impedance of the glass melt as a function of frequency using a calibrated platinum/rhodium probe attached to a Hewlett-Packard model 4194A impedance analyzer. Measurements are performed over temperature ranges similar to those employed for the viscosity measurements $\left(950^{\circ} \mathrm{C}\right.$ to $\left.1250^{\circ} \mathrm{C}\right)$. The resulting frequency dependent impedance data are analyzed in terms of an equivalent circuit to obtain the direct current conductivity. The measured data are then interpolated to standard temperatures using the Vogel-Fulcher equation:

$$
\ln \sigma=\left[A /\left(T-T_{o}\right)\right]+C,
$$

where $A, C$, and $T_{o}$ are fitting parameters. Estimated uncertainties in the conductivity measurements are \pm 20 relative $\%$.

\subsubsection{Product Consistency Test}

The product consistency test (PCT; ASTM C 1285) is used to evaluate the relative chemical durability of glasses by measuring the concentrations of the chemical species released from 100-200 mesh crushed glass $(75-149 \mu \mathrm{m})$ to the test solution (de-ionized water in this case). PCT tests on the HLW glasses are performed at $90^{\circ} \mathrm{C}$, in accordance with the current WTP contract requirement. The ratio of the glass surface area to the solution volume for this test is about $2000 \mathrm{~m}^{-1}$ (typically, $10 \mathrm{~g}$ of 100-200 mesh glass is immersed in $100 \mathrm{ml}$ deionized water). All tests are conducted in triplicate, in 304L stainless steel vessels, and in parallel with a standard glass included in each test set. The internal standard is the ANL-LRM reference glass [41] and/or the DWPF-EA glass, both of which have undergone round-robin testing. The leachates are sampled at predetermined times, the first of which is seven days. One milliliter of sampled leachate is mixed with $20 \mathrm{ml}$ of $1 \mathrm{M} \mathrm{HNO}_{3}$ and the resulting solution is analyzed by DCP-AES; another $3 \mathrm{ml}$ of sampled leachate is used for $\mathrm{pH}$ measurement. 


\subsubsection{Toxicity Characteristic Leaching Procedure (TCLP)}

The TCLP is performed on glass samples per VSL SOPs [40] based on Environmental Protection Agency (EPA) SW-846 Method 1311. The test is used to determine the leach resistance of crushed glass $\left(<3 / 8^{\prime \prime}\right)$ in a sodium acetate buffer solution after 18 hours at $22^{\circ} \mathrm{C}$ with constant end-over-end agitation. A mass of 100 grams of glass is leached in 2 liters of TCLP extraction solution, according to the extraction method for non-volatiles. The surface area to volume ratio for this test is about $20 \mathrm{~m}^{-1}$, which is about two orders of magnitude lower than that in the PCT. The leachate concentrations are measured by DCP-AES. The overall uncertainty associated with this test for glass samples is estimated from evaluation of VSL data to be $\pm 20 \%$.

\subsubsection{Determination of One-Percent Crystal Fraction Temperature $\left(T_{1 \%}\right)$}

One-percent crystal fraction temperature $\left(\mathrm{T}_{\mathbf{1}} \%\right)$ is determined per VSL SOPs [40] as described below. Glass samples (about 5 grams each) are heat-treated in platinum, platinum-gold, or platinum-rhodium crucibles $(5 \mathrm{ml})$ at a pre-melt temperature of $1200^{\circ} \mathrm{C}$ for 1 hour, followed by heat treatment for 70 hours at prescribed temperatures between $800^{\circ} \mathrm{C}$ and $950^{\circ} \mathrm{C}$. At the end of the heat-treatment period, the glass samples are quenched by contacting the crucible with cold water. This quenching freezes in the phase assemblage in equilibrium with the melt at the heat-treatment temperature. The sample is then prepared for Scanning Electron Microscopy/Energy Dispersive X-ray Spectroscopy (SEM/EDS) examination by grinding and sieving (-18 mesh). Microscopic and spectroscopic examination (Model JSM-5910LV, equipped with Oxford Instruments INCAEnergy 300 system) is used to determine the volume fraction of crystalline phases and the identity of the dominant crystalline phases. For each glass, heat treatments are performed to obtain non-zero vol\% crystal data for at least three temperatures in order to reasonably constrain the $\mathrm{T}_{1 \%}$ value.

The $\mathrm{T}_{1 \%}$ value for each glass is obtained by linear regression of the heat-treatment temperature $\left({ }^{\circ} \mathrm{C}\right)$ as the dependent variable versus crystal fraction (vol\%) as the independent variable. The choice of vol\% (which has the larger measurement error) as the independent variable, rather than the temperature (which has the smaller measurement error), is contrary to the selection that would normally be made for regression. However, as discussed in a previous $\mathrm{T}_{1 \%}$ modeling report [42], there are significant advantages to using this "inverse regression" approach in the present application. The differences in the $\mathrm{T}_{1 \%}$ values estimated using either choice of independent variable are small. Based on results from modeling studies, the standard deviation in estimating $\mathrm{T}_{1 \%}$ values is about $27^{\circ} \mathrm{C}$ [42].

\subsection{Measurements of Sulfate Solubility in Glass Melts}

\subsubsection{Over-Saturation Melting}

The sulfate solubility in selected glasses was measured using over-batching with sulfate. The selected HLW glasses were powdered to give -40 mesh $(<425 \mu \mathrm{m})$ samples. About $20 \mathrm{~g}$ of 
the glass powder was thoroughly mixed with reagent grade ammonium sulfate $\left(\left(\mathrm{NH}_{4}\right)_{2} \mathrm{SO}_{4}\right)$. The amount of ammonium sulfate added was equivalent to $5 \mathrm{wt} \%$ of $\mathrm{SO}_{3}$ in glass if all sulfur was retained in the glass. The glass/ammonium sulfate mixture was loaded into a $\mathrm{Pt} / \mathrm{Au}$ crucible $(50-\mathrm{ml})$ with cover and re-melted at $1150^{\circ} \mathrm{C}$ for 1 hour. At the end of 1 hour, the crucible was cooled naturally to room temperature and the glass recovered for examination. Washing of glass chunks to remove salt phases was followed by grinding (-200 mesh) and then washing of the glass powder to ensure removal of all sulfate salts. Analysis of $\mathrm{SO}_{3}$ in the powdered and washed glass sample provided an estimate of sulfate solubility in the HLW glass.

The use of ammonium sulfate instead of other sulfate salts (e.g., $\mathrm{Na}_{2} \mathrm{SO}_{4}$ ) has the advantage of minimizing the effect on the original glass composition since its decomposition results in volatile ammonia. (Thermal decomposition of ammonium sulfate in the presence of zinc and other oxides has been developed as a means of recovering ammonia and sulfate [43]).

\subsubsection{Gas Bubbling Experiments}

The sulfate solubility $\left(1150^{\circ} \mathrm{C}\right)$ in selected HLW glass melts was also determined by analyzing the chemical composition of the glass melt in equilibrium with a molten sulfate phase at the designated test temperature. During the experiment, $\mathrm{SO}_{3}$ is loaded into the glass melt gradually by bubbling a gaseous mixture of $\mathrm{SO}_{2}, \mathrm{O}_{2}$, and $\mathrm{N}_{2}$ through the molten glass. The partial pressure of $\mathrm{SO}_{3}\left(\mathrm{P}_{\mathrm{SO}_{3}}\right)$ is controlled through the chemical reaction between $\mathrm{SO}_{2}$ and $\mathrm{O}_{2}$ at the test temperature in the presence of a catalyst (the platinum bubbling tube). Gases are mixed, and the flow is regulated using a gas proportioner with the flow tubes calibrated for each individual gas stream. The mixed gas is then transported through flexible polyvinyl chloride (PVC) tubing fitted to a Pt bubbling tube, the other end of which is immersed in the molten glass. The flow rate of the mixed gas is $30 \mathrm{ml} / \mathrm{min}$ (at room temperature).

For each of the sulfate saturation experiments by gas bubbling, 100 grams of test glass is placed in a 200-ml Pt crucible and covered by a Pt sheet furnished with a slot for introducing the gas bubbling tube. The crucible is then loaded in the center of the platform of a Del-Tech furnace preheated to $1150^{\circ} \mathrm{C}$. The gas mixture is introduced through the roof of the furnace, passing through preheated $\mathrm{Pt}$ tubes (24 to 36 inches in length). For each prescribed gas mixture of controlled $\mathrm{P}_{\mathrm{SO}_{3}}$, the test glass melt is bubbled continuously for 3.5 hours. At the end of each bubbling period, the setup is removed from the furnace for inspection for the development of a sulfate layer, and sampling ( $\approx 3-5$ grams). A complete bubbling experiment usually involves multiple bubbling cycles, with step-wise increases of $\mathrm{P}_{\mathrm{SO}_{3}}$. Typically, two to three more bubbling cycles would be conducted after the onset of a sulfate layer in order to ensure saturation.

To determine sulfate solubility in silicate glass by means of bulk analysis (e.g., XRF), it is necessary to remove any separated sulfate salt from the glass in order to produce a homogeneous glass sample for analysis. Glasses sampled from gas-bubbled experiments, especially in the oversaturated condition, contain numerous inclusions of sulfate salt that are finely dispersed inside the glass. Consequently, care must be exercised to separate the sulfate inclusions from the bulk glass. The glass samples collected at the end of each bubbling cycle are powdered ( $<75$ micron) and then washed to remove possible inclusions of segregated sulfate salt 
prior to analysis by XRF for chemical composition. The solvents used for washing include dilute $(0.75 \mathrm{wt} \%) \mathrm{HNO}_{3}$ to remove alkali and calcium sulfates. Previous tests have shown that similar washing of homogeneous glass powder without sulfate inclusion does not remove significant amounts of any of the glass components.

\subsection{Metal Glass-Contact Corrosion Tests}

\subsubsection{Coupon Preparation}

Rectangular coupons of Inconel 690 and MA758 were machined from the bulk material and their surfaces polished (Figure 1.1). The dimensions of the coupons are 0.300 by 0.150 inch in cross-section and of sufficient length to be immersed in the molten glass to a depth of 0.9 inch (Figure 1.2). All dimensions of the coupons are measured by micrometer to better than $0.5 \mathrm{mil}$ before the tests. The precision of the parallel surface is better than 0.001 inch.

\subsubsection{Metal Corrosion Test}

Corrosion tests with molten glass were conducted using VSL SOPs [40] with the experimental arrangement shown schematically in Figure 1.2. The standard experimental setup consists of a $50 \mathrm{ml}$ platinum crucible placed into a quartz holder. On the top of the crucible there is a cover with a $5 \mathrm{~mm}$ slot. The coupon is placed through the slot and suspended by a rod that is placed through a hole drilled through one end of the coupon. For each corrosion test, 70 grams of glass is melted at $1150^{\circ} \mathrm{C}$ (nominal) for 30 minutes; this quantity gives an $\mathrm{S} / \mathrm{V}$ ratio for these tests of $0.15 \mathrm{~cm}^{-1}$ and the crucible is filled to $3 / 4$ of its height $(29 \mathrm{~mm})$ with glass. The coupon with the lid is preheated to $800^{\circ} \mathrm{C}$, allowing an oxide layer to form on the coupon, which is then placed into the crucible with the molten glass. The experimental setup is then placed into a furnace that is preheated to the desired test temperature $\left(1150^{\circ} \mathrm{C}\right)$. After the designated period of time, the setup is removed from the furnace, the coupon is extracted from the glass, and the glass melt is poured into a graphite mold for further analyses. The coupon with the glass coating is then embedded in epoxy. Because of the relatively high sulfate contents, the glass melts in direct contact with the metal coupons were replenished two times (after the second and the fourth days) in an attempt to compensate for sulfate volatilization. During glass replenishment, the coupon with lid was removed from the initial crucible, excess glass was allowed to drip off the coupon, and the coupon with lid was placed in a crucible containing fresh glass that had been heated to the test temperature. The glass from the first crucible was poured into a graphite mold and sampled for further analysis. At the end of the 7-day test, the coupon and glass were removed according to the same procedure for further analysis.

The standard metal corrosion test method was further modified, during this work to suppress the rapid volatilization of sulfur from the glass melt in the standard test condition in which the test crucible with metal coupon is open to air. After testing in partially closed and completely closed crucible conditions, it was concluded that the most effective test setup for sulfate retention required the use of a completely closed test vessel that would prevent loss of sulfur from the standard metal corrosion setup of Pt crucible with test metal coupon and glass. In 
the present work, a $100 \mathrm{ml}$ alumina crucible $\left(99 \% \mathrm{Al}_{2} \mathrm{O}_{3}\right)$ with matched lid was used to contain the standard metal corrosion setup that had been prepared by the standard method as described earlier in this section. After loading the test crucible with the metal coupon, the assembly was placed inside the alumina crucible and the lid was added. The lid was sealed completely using a nepheline ceramic paste, which melts to produce a highly viscous sealant at the test temperature. The interior volume within the alumina crucible was further reduced by adding ceramic filler blocks made of Zirmul. The sealed test rig was placed into the test furnace at room temperature, and heated gradually to $1150^{\circ} \mathrm{C}$ at $600^{\circ} \mathrm{C} /$ hour. The setup was removed from the hot furnace after 7 days of testing and cooled to room temperature in a ventilated cooling chamber. The alumina crucible with lid was then cut open to retrieve the standard test setup. The metal coupon was subsequently removed from the softened glass after being reheated to $1150^{\circ} \mathrm{C}$ briefly in open air. The glass melt was poured and collected for XRF analysis.

\subsubsection{Optical Microscopy}

After each corrosion test, the reacted coupons were embedded in resin and then sectioned at the mid-point (Figure 1.1) and polished. Both halves of the sectioned coupons were examined using a microscope for corrosion characteristics (e.g., morphology of new, modified, and original phases, the texture of the reacted alloys, etc.). The thickness of the reacted coupon was measured using a measuring microscope, which has a precision of better than $0.05 \mathrm{mil}(1.27 \mu \mathrm{m})$. Typically, 10 transverse lines were measured perpendicular to the length of the coupon. The overall uncertainty associated with these measurements is about 0.5 mil. The dimensional loss is calculated as half of the difference of the measured widths between the original and reacted coupons near the glass line (or sometimes referred as the neck if such a feature develops) and at the location corresponding to half of the immersed length of the coupon (referred to as the half-down position). The sectioned coupons are further characterized using Scanning Electron Microscopy - Energy Dispersive X-ray Spectroscopy (SEM-EDS).

\subsubsection{SEM/EDS}

Scanning electron microscopy (JEOL JMS 5910LV) with a digital imaging system was used to characterize the microstructure of alloy materials after corrosion. Typical magnifications used range from $25 \times$ to $5,000 \times$. Energy dispersive X-ray spectroscopy (EDS) was used to analyze the chemical composition of the glass, crystalline oxide phases, and the corroded materials. SEM measurements typically provide better results on the structurally damaged zone than does optical microscopy. The elemental profiles were obtained by either EDS line-scanning or point analysis from the glass-metal interface to the center of the coupon.

\subsection{DM10 Melter System Description}

Testing was conducted on one of the two DM10 melter systems installed at the VSL, shown in Figure 1.3. A schematic diagram of the DM10 system is shown in Figure 1.4 and the principal components of the system are described in the following sections. 


\subsubsection{Feed System}

The feed container is mounted on a load cell for weight monitoring and is stirred continuously except for periodic, momentary interruptions during which the weight is recorded. The material in the feed container is constantly recirculated, which provides additional mixing. The recirculation loop extends to the top of the melter where feed is diverted from the recirculation loop into the melter through a Teflon-lined feed line and water-cooled feed tube. The feed rate is regulated by a peristaltic pump that is located between the recirculation loop and the feed tube.

\subsubsection{Melter System}

A DuraMelter 10 (DM10) system was used for this work. The Monofrax K3 ceramic refractory-lined melter includes two Inconel 690 plate electrodes that are used for joule-heating of the glass pool and a bubbler for mixing the melt. The DM10 melter has a melt surface area of $0.02 \mathrm{~m}^{2}$ and glass inventory of about $8 \mathrm{~kg}$. The glass product is removed from the melter by means of an air-lift discharge system.

\subsubsection{Off-Gas System}

For operational simplicity, the DM10 is equipped with a dry off-gas treatment system involving gas filtration operations only. Exhaust gases leave the melter plenum through a film cooler device that minimizes the formation of solid deposits. The film-cooler air has constant flow rate and its temperature is thermostatically controlled. Consequently, the exhaust gases passing through the transition line (between the melter and the first filtration device) can be sampled at constant temperature and air flow rate. The geometry of the transition line conforms to the requirements of the 40-CFR-60 air sampling techniques. Immediately downstream of the transition line are cyclonic filters followed by conventional pre-filters and HEPA filters. The temperature of the cyclonic filters is maintained above $150^{\circ} \mathrm{C}$ while the HEPAs are held above $100^{\circ} \mathrm{C}$ to prevent moisture condensation. The entire train of gas filtration operations is duplicated and each train is used alternately. An induced draft fan completes the system.

\subsubsection{Sampling Points}

The sampling points available on the DM10 system and used in these tests are as follows:

- Melter Feed: Samples of the melter feed taken either from the parent feed batch or the melter feed line to provide confirmation of the feed composition.

- Glass Product: Samples of the glass product taken from glass that is air-lift discharged into steel cans.

- Glass Pool: Glass samples taken directly from the glass pool ("dip" samples). 
- Off-gas: A sampling point located down stream of the HEPA filter was used for continuous emissions monitoring (CEM) by Fourier transform infra-red spectroscopy (FTIR) of a wide variety of gaseous species, including $\mathrm{NO}, \mathrm{NO}_{2}, \mathrm{~N}_{2} \mathrm{O}, \mathrm{CO}$, and $\mathrm{SO}_{2}$. 


\section{SECTION 2.0 \\ WASTE SIMULANT AND GLASS FORMULATIONS}

\subsection{WTP C-106/AY-102}

This high-iron HLW simulant is based on actual waste samples from Hanford C-106/AY-102 waste blend and provided the compositional basis for previous tests on the DM100 [29] and DM1200 [16] melter systems. Analytical data for actual C-106/AY-102 waste samples were previously provided by the WTP Project for developing HLW glass formulations to support vitrification testing of actual C-106/AY-012 waste [13].

\subsubsection{C-106/AY-102 Waste Simulant}

Samples of Hanford C-106/AY-102 actual waste solids were shipped to Savannah River National Laboratory (SRNL) where they were combined and the composite sample analyzed. Washing and caustic leaching were the HLW pretreatments performed before analysis. Table 2.1 lists the analyzed composition of C-106/AY-102 in terms of non-volatile oxides, as provided by the WTP Project [44]. Table 2.1 also lists the cesium eluate from LAW pretreatment of AW-101 waste [45], which was blended with the C-106/AY-102 solids to give the HLW simulant in earlier tests $[16,29]$. The blending of LAW pretreatment products is retained in the current HLW simulant so that test data to be obtained can be compared directly with the baseline data. The blending ratio was determined from the WTP dynamic process flowsheet model (G2), with the mass ratio of $\mathrm{AW}-101$ waste oxides to $\mathrm{C}-106 / \mathrm{AY}-102$ oxides equal to about $5.9 \times 10^{-4}$. The blended composition is given in Table 2.1. As can be seen, the AW-101 cesium ion-exchange eluate is essentially composed of a solution of sodium (nitrate) and boron, together with minor amounts of other alkalis and selected metal ions, including barium, cerium, copper, nickel, and tin. The blended waste composition is very similar to that of the C-106/AY-102 waste, primarily because of the low blending ratio. It should also be noted that the impact of blending on the iron concentration is negligible.

The blended waste in Table 2.1 contains 32 non-volatile components and was modified to give the HLW simulant for the previous and currents tests. The modifications are made to keep the number of components at a manageable level and they include: i) omitting the minor components (i.e., components that make up $<0.05 \mathrm{wt} \%$ in glass, which corresponds to about $0.12 \mathrm{wt} \%$ in waste, on an oxide basis); ii) omitting silver, which was not included in earlier C-106/AY-102 melter tests; and iii) substituting sodium for potassium, lanthanum for gadolinium, and zirconium for uranium (to eliminate the use of radioactive materials). Renormalization after these modifications results in the HLW waste simulant, the composition of which is shown in Table 2.1. It can be seen that iron is by far the most abundant component in the simulant $\left(38.12 \mathrm{wt} \% \mathrm{Fe}_{2} \mathrm{O}_{3}\right.$ ), followed by aluminum and manganese (sodium and silicon are present in higher concentrations but both are part of the glass forming additives for the WTP). 
To complete the formulation of the HLW waste simulant, the volatile components need to be defined. For this purpose, the concentrations of carbonate, nitrate, nitrite, and total organic carbon (TOC) from previous C-106/AY-102 melter tests are adopted [16, 29]. The complete HLW waste simulant is given in Table 2.2.

\subsubsection{C-106/AY-102 Glass Formulations and Melter Feed Formulations}

After definition of the composition of the blended C-106/AY-102 waste, new glass formulations were developed and tested at VSL to support actual waste testing [15]. The glass composition selected as the basis to vitrify C-106/AY-102 waste, HLW04-09, is presented in Table 2.2. The same glass formulation, with minor modifications including those made in defining the simulant described above, was used in previous melter tests [16, 29]. Another more recently developed glass composition that was optimized to increase the glass production rate and waste loading for this waste stream [30] is also provided in Table 2.2.

The base glass HLW04-09 has a nominal waste loading of $37.10 \mathrm{wt} \%$, incorporating $14.03 \mathrm{wt} \%$ of $\mathrm{Fe}_{2} \mathrm{O}_{3}$. This can be compared to the earlier HLW glasses formulated for high-iron wastes for the WTP Project, which are generally designed to demonstrate the capability to comply with the Contract Minimum Component Limits [46] and are limited to about $12.50 \mathrm{wt} \%$ of $\mathrm{Fe}_{2} \mathrm{O}_{3}$ [14]. Waste loadings in high-iron HLW glass formulations are found to be limited typically by the formation of spinel phases. Glass formulation efforts, however, have been successful in increasing the waste loadings $\left(>14 \mathrm{wt} \% \mathrm{Fe}_{2} \mathrm{O}_{3}\right)$ by suppressing spinel formation through the use of various additives [14]. Subsequently, the glass was reformulated as HLW-NG-Fe2, further increasing the waste loading to $42 \mathrm{wt} \%$ and incorporating $16.01 \mathrm{wt} \%$ of $\mathrm{Fe}_{2} \mathrm{O}_{3}[30]$.

\subsection{Previously Tested High Sulfur HLW Waste Stream [26]}

\subsubsection{Simulant Composition}

The composition of the HLW simulant used for previous testing was selected from waste batches whose waste loadings in glass formulation development are limited by the $\mathrm{WTP}_{3}$ constraint [26]. Per the River Protection Project System Plan 6 [36], there are over 800 such waste batches at WTP, with $\mathrm{SO}_{3}$ concentrations ranging from $1.04 \mathrm{wt} \%$ to $4.38 \mathrm{wt} \%$. If the minimum component limit in HLW glass for $\mathrm{SO}_{3}$ of $0.5 \mathrm{wt} \%$ is used [36], the waste loadings in HLW glass products for these wastes range from a high of $48 \mathrm{wt} \%$ down to a low of $11 \mathrm{wt} \%$. The selected waste batch is Number 4028 in System Plan 6 [36]. This waste has a $\mathrm{SO}_{3}$ concentration of $4.15 \mathrm{wt} \%$. This waste contains over 50 component oxides, including radioactive oxides such as $\mathrm{UO}_{3}$. In order to maintain a manageable number of components and to eliminate the use of radioactivity for melter testing, all minor components (i.e., $<0.1 \mathrm{wt} \%$ ) and radioactive oxides are omitted in the definition of the HLW simulant. The resulting HLW composition, which is given in Table 2.3, contains $96.83 \mathrm{wt} \%$ of the original oxides. The HLW simulant composition is obtained by normalization of the oxide composition, which is also given in Table 2.3 . 
The HLW simulant listed in Table 2.3 shows considerable compositional differences (in $\mathrm{wt} \%$ oxide) from other HLW simulants used in earlier melter tests. Most of the previously investigated $\mathrm{HLW}$ simulants are high in $\mathrm{Fe}_{2} \mathrm{O}_{3}$ and/or $\mathrm{Al}_{2} \mathrm{O}_{3}$. By contrast, the predominant component in the current HLW simulant is $\mathrm{Na}_{2} \mathrm{O}(36.12 \mathrm{wt} \%)$, which is known to play a significant role in determining sulfate solubility $[4,5,26]$. There are also relatively high concentrations of $\mathrm{P}_{2} \mathrm{O}_{5}(10.99 \mathrm{wt} \%)$ and $\mathrm{Al}_{2} \mathrm{O}_{3}(10.80 \mathrm{wt} \%)$ in the simulant, followed by $\mathrm{Bi}_{2} \mathrm{O}_{3}$ $(6.98 \mathrm{wt} \%)$ and $\mathrm{Fe}_{2} \mathrm{O}_{3}(6.55 \mathrm{wt} \%)$. Table 2.4 provides a recipe to produce the HLW simulant for $100 \mathrm{~kg}$ of waste oxides. The compositions of volatile components in the HLW are not given by System Plan, therefore the concentrations used in previous melter testing are substituted in deriving the recipe in Table 2.4. The volatiles and their respective concentrations are: carbonate (4.65 g/100 g oxide), nitrate (0.784 g/100 g oxide), nitrite (0.012 g/100 g oxide), and organic carbon $(0.026 \mathrm{~g} / 100 \mathrm{~g}$ oxide).

\subsubsection{Glass Formulation}

The high sulfur waste simulant was produced at VSL from reagent grade chemicals, as shown in Table 2.4. The feed for the HLWS-09 formulation was produced by the addition of kyanite, boric acid, calcium carbonate, vanadium pentoxide, silica, and zircon to the simulant in the calculated proportions for each test. The initial target glass and the analyzed glass composition from melter testing with the highest sulfur content are provided in Table 2.5. The sulfur content of the melter feed was increased using two different methods: one by systematically increasing the proportion of the sulfur-rich waste to the additives in the feed and the other by adding progressively more sulfuric acid. Feeds from the end of two test segments from each composition were sampled and analyzed to determine physical properties and confirm the chemical composition. The melter glass with the highest measured sulfur content of $1.64 \mathrm{wt} \% \mathrm{SO}_{3}$ was used for corrosion testing.

\subsection{New High Sulfur HLW Waste Stream}

\subsubsection{Simulant Composition}

As before [26], the composition of the new HLW simulant for testing is selected from waste batches whose waste loadings in glass formulation development are limited by the WTP $\mathrm{SO}_{3}$ constraint [36]. Based on the Hanford Tank Waste Operations Simulator (HTWOS) model run used to generate the River Protection Project System Plan [36], there are over 800 such waste batches at WTP, with the $\mathrm{SO}_{3}$ concentrations ranging from $1.04 \mathrm{wt} \%$ to $4.38 \mathrm{wt} \%$. If the minimum component limit in HLW glass for $\mathrm{SO}_{3}$ of $0.5 \mathrm{wt} \%$ is used [36], the waste loadings in HLW glass products for these wastes correspond to $48 \%-11 \%$. For the present work, the selected waste batch is Number 1925 in the HTWOS model run. This waste has a $\mathrm{SO}_{3}$ concentration of $1.67 \mathrm{wt} \%$. This waste also has over 50 component oxides, including radioactive oxides such as $\mathrm{UO}_{3}$. In order to maintain a manageable number of components and to eliminate the use of radioactivity in testing, all minor components (i.e., $<0.1 \mathrm{wt} \%$ ) and radioactive oxides are omitted in the definition of the HLW simulant. The resulting HLW composition, which is 
given in Table 2.6, contains $91.15 \mathrm{wt} \%$ of the original oxides. The HLW simulant composition is obtained by normalization of the oxide composition, which is also given in Table 2.6.

The HLW simulant listed in Table 2.6 shows considerable compositional (in wt $\%$ oxide) differences from other HLW simulants found in earlier melter tests. Typical HLW simulants are high in $\mathrm{Fe}_{2} \mathrm{O}_{3}$ and/or $\mathrm{Al}_{2} \mathrm{O}_{3}$. By contrast, the predominant component in the current $\mathrm{HLW}$ simulant is $\mathrm{Na}_{2} \mathrm{O}$ (23.94 $\mathrm{wt} \%$ ), while the concentrations of $\mathrm{CaO}\left(11.24 \mathrm{wt} \%\right.$ ) and $\mathrm{Cr}_{2} \mathrm{O}_{3}$ $(1.81 \mathrm{wt} \%)$ are among the highest in the wastes examined; all of these oxides are known to affect sulfate solubility $[4,5,18,26]$. There is also a relatively high concentration of $\mathrm{MnO}(8.70 \%)$. The concentrations of $\mathrm{Al}_{2} \mathrm{O}_{3}(15.75 \mathrm{wt} \%)$ and $\mathrm{Fe}_{2} \mathrm{O}_{3}(10.40 \mathrm{wt} \%)$ are relatively low for a $\mathrm{HLW}$ stream. Table 2.7 provides a recipe to produce the HLW simulant (for $100 \mathrm{~kg}$ of waste oxides). The compositions of volatile components in the HLW are not given by the HTWOS model run; therefore the concentrations used in previous melter testing are substituted in deriving the recipe in Table 2.7. The volatiles and their respective concentrations are: carbonate $(4.65 \mathrm{~g} / 100 \mathrm{~g}$ oxide), nitrate (0.784), nitrite (0.012), and organic carbon $(0.026)$.

\subsubsection{Glass Formulation}

New HLW glass formulations for the current high sulfur HLW (Table 2.6) were developed and tested to incorporate the highest waste loading while maintaining acceptable processing and durability properties. As discussed above, the HLW simulant composition in Table 2.6 shows considerable difference from other HLW compositions tested previously. Nonetheless, previous glass formulation experience and data, for both Hanford HLW and LAW, were valuable in guiding the present development work. The achievable waste loadings were expected to be limited primarily by sulfate solubility and crystal formation. An approach similar to that used in earlier development of high sulfate HLW glasses was followed: additives including $\mathrm{CaO}, \mathrm{Li}_{2} \mathrm{O}$ and $\mathrm{V}_{2} \mathrm{O}_{5}$ were used to increase sulfate solubility in glass, while glasses prepared were characterized first to determine sulfate solubility and crystal formation. Glass property-composition models were used to estimate other properties such as viscosity and electrical conductivity when applicable before they were experimentally measured for selected glasses.

Table 2.8 summarizes the waste loadings and glass additives for the HLW glass formulations developed and tested. The glasses were labeled HLWS-21 through HLWS-33. With the exception of HLWS-22, all glasses have waste loadings between $50 \mathrm{wt} \%$ and $54 \mathrm{wt} \%$, which correspond to target $\mathrm{SO}_{3}$ loadings in glass of between $0.92 \mathrm{wt} \%$ and $0.99 \mathrm{wt} \%$. These levels are relatively high when compared to the average of $0.70 \mathrm{wt} \%$ from an earlier study of HLW glasses [18] but are lower than the target of $1.29 \mathrm{wt} \%$ for HLWS-09, which was developed for a different HLW simulant in previous work [26]. As discussed below, increased $\mathrm{SO}_{3}$ loadings beyond $0.99 \mathrm{wt} \%$ are achievable for the current HLW simulant but need to be balanced against the formation of various secondary crystalline phases.

Crucible melts for HLWS-21 through -33 were prepared and the compositions of the resulting glasses were analyzed by XRF, which are given in Table 2.9. As frequently observed before, the measured $\mathrm{SO}_{3}$ contents are generally lower than the targets, likely as a result of 
volatilization of sulfur during melting. The solubilities of sulfur in HLW glasses were measured by over-saturation melting and, for selected glasses, gas bubbling. Table 2.10 presents the sulfate solubility data. Figure 2.1 compares the solubilities as measured by over-saturation and gas bubbling experiments. The two procedures produced data that are in good agreement, with the gas bubbling method giving slightly higher solubilities. Figure 2.2 compares the measured solubilities of the HLWS glasses with the target $\mathrm{SO}_{3}$ concentrations as defined by waste loadings. The data for the previously tested HLWS-09 are included for comparison. Figure 2.2 shows that all glasses formulated can incorporate the required target $\mathrm{SO}_{3}$ contents, with considerable margins in several cases. In particular, for HLWS-09, which was selected for a previous melter test as the target glass formulation [26], the measured sulfate solubility (by gas bubbling) of $1.78 \mathrm{wt} \%$ is significantly higher than the target $\mathrm{SO}_{3}$ content of $1.29 \mathrm{wt} \%$ at the nominal waste loading. However, it is important to distinguish the thermodynamic sulfate solubility limit from the amount of sulfate that can be tolerated in the melter feed without leading to the formation of a separate sulfate phase. Due to kinetic and other transient effects arising from the complex environment in melt processing, secondary sulfate phase formation can occur before the sulfate concentration in the glass pool reaches the sulfate solubility limit.

The measured solubilities (by over-saturation) for the test glasses range from $1.04 \mathrm{wt} \%$ to $1.51 \mathrm{wt} \% \mathrm{SO}_{3}(1.01 \mathrm{wt} \%$ to $1.61 \mathrm{wt} \%$ by gas bubbling). The glass formulations with the highest sulfate solubilities with respect to the different waste loadings are HLWS-22 (1.50 wt $\%$ at waste loading of $43 \mathrm{wt} \%)$, -23 (1.51 wt \%, $50 \mathrm{wt} \%)$, -25 (1.49 wt\%, $52 \mathrm{wt} \%)$, -29 (1.11 wt\%, $54 \mathrm{wt} \%)$. The additive $\mathrm{V}_{2} \mathrm{O}_{5}$ was used in each of these formulations to increase sulfate solubility. Increased $\mathrm{CaO}$ concentration is also generally beneficial to improve sulfate solubility in the glasses tested, as has been noted previously [26]. In spite of the relatively high concentration of $\mathrm{CaO}$ in the waste $(11.24 \mathrm{wt} \%), \mathrm{CaO}$ was tested as an additive in five glass formulations; most of these formulations can load more than $1.35 \mathrm{wt} \% \mathrm{SO}_{3}$. The use of $\mathrm{CaO}$ in these glass formulations, however, is limited by the formation of calcium phosphate (apatite), as discussed below.

While $\mathrm{V}_{2} \mathrm{O}_{5}$ and $\mathrm{CaO}$ are used to enhance sulfate solubility, simple correlations between sulfate solubility and glass composition are not easily discernible in HLW glasses. No clear trends can be observed between sulfate solubility and most elements, particularly sodium and total alkali. A previous study noted that sulfate solubility generally increases with the combined concentrations of calcium, strontium, and boron [26]. Figure 2.3 shows that the present data fit well in that relationship, with no obvious outliers from the broad trend.

Another major constraint that limits waste loading during glass formulation for the HLW simulant in Table 2.6 is crystal formation. All glasses prepared were therefore characterized with respect to percent crystallinity and phase identification after heat treatment at various temperatures. The data are shown in Table 2.10. The primary crystalline phases that formed upon heat treatment of the HLWS glasses are calcium phosphate and spinel. Elongated crystals of calcium phosphate with lengths up to $100 \mu \mathrm{m}$ are observed in all glass samples heat treated at $900^{\circ} \mathrm{C}$ or below. Figure 2.4 provides an example of a microscopic image of such a sample. The calcium phosphate crystals, which often incorporate considerable amounts of fluoride, are in general more abundant than spinel crystals at lower heat-treatment temperatures. As the heat-treatment temperature increases, the phosphate crystals dissolve into the glass matrix such that spinel often becomes the only crystalline phase present at $950^{\circ} \mathrm{C}$ and above. Calcium 
phosphate crystals were not observed in any sample at heat temperature above $950^{\circ} \mathrm{C}$. In addition to iron, substantial amounts of chromium, manganese, and nickel are detected in the spinel crystals. The crystallinity data from heat treated glass samples were used to estimate the $T_{1 \%}$ values and the regression results are given in Table 2.11. Plots of volume percent crystals measured by SEM/image analysis versus heat treatment temperature are given in Appendix A. Comparison of results from SEM/image analysis and quantitative X-ray diffraction (XRD) measurements of volume percent crystals showed good agreement between the two methods.

In addition to sulfate solubility and crystallinity, viscosity, electrical conductivity and PCT responses were measured for selected glasses. The measured data are given in Table 2.10. Table 2.10 also includes viscosity and electrical conductivity values calculated at standard temperatures using the Vogel-Fulcher equations fitted to the experimental data.

The melt rate of formulation HLWS-27 was evaluated by crucible scale testing in a vertical gradient furnace (VGF). Details of VGF testing have been provided previously [33]. In these tests, a dried melter feed sample is subjected to a vertical temperature gradient from $600^{\circ} \mathrm{C}$ to $1150^{\circ} \mathrm{C}$ over time periods of 30 minutes and 60 minutes. The degree of feed conversion over the test duration was assessed based on the melting that had occurred and the structure of the reacted feed material assembly. The top view and cross section images of the reacted samples after 30 minute and 60 minute VGF tests are shown in Figure 2.5. The feed samples showed very porous structures, with a thick foam layer that did not collapse, even after 60 minutes of reaction. The rate of conversion from feed to glass was towards the low end of the range relative to many of the fast melting feeds examined previously [33] and therefore further improvement may be possible. The melt rate for the HLWS-27 feed was assigned a ranking of 4 to 5 (see Table 2.12) based on the extent of feed conversion.

Four HLWS glasses (HLWS-24, -27, -28, -32) were characterized with respect to TCLP. Table 2.13 summarizes the TCLP results. All glasses tested easily meet the relevant HLW delisting requirements.

Based on characterization data collected, the glass formulation HLWS-27 was selected for melter testing, which is described in Section 4.0. 


\section{SECTION 3.0 CORROSION OF Ni-Cr ALLOYS IN SULFATE-BEARING HLW GLASS MELTS}

\subsection{Introduction}

As outlined in the Test Plan [25], the metal corrosion tests were aimed at providing data on the corrosion characteristics of the Ni-Cr super alloys Inconel 690 and MA758 in three selected HLW glass melts. The compositions of the glasses are given in Table 3.1. Based on experience in sulfate phase mitigation for the Hanford LAW vitrification program, formation of the detrimental molten sulfate layer can be generally prevented via design of glass and melter feed formulations coupled with effective bubbling implementation during melt processing. The recent glass formulations for sulfate-rich HLW streams contain $\mathrm{SO}_{3}$ at levels comparable to those for LAW glasses, which is much higher than those in the baseline HLW formulations tested previously in melters [26]. In view of the highly corrosive nature of sulfate, both as a separated sulfate layer and as sulfate species in the glass melt, the higher sulfate concentrations in the enhanced HLW formulations could lead to reduced lifetime of metallic components in the HLW melter.

Inconel 690 and MA758 have been identified as the materials of choice for application in the WTP melters. They generally resist the attack by molten glass and to a lesser degree by molten salt, as shown in metal corrosion tests with LAW glasses. Inconel 690 and MA758 react with molten glass rather slowly at typical melter operating temperatures. However, this presents challenges in assessing the corrosion damage to the alloys by a molten glass, particularly if it is judged solely based on the dimensional loss determined in a short term laboratory test. Therefore, the interior structural damage incurred due to corrosion, which can be assessed by electron microscopy, provides valuable additional information and is often more indicative of the corrosion process. The key parameters for assessing the corrosion damage to $\mathrm{Ni}-\mathrm{Cr}$ based super alloys are:

- The dimensional loss of the test coupons;

- Internal structural degradation, as reflected by grain boundary damage, oxidation, or glass melt intrusion;

- Internal compositional alteration, as reflected by dealloying, in particular, the depletion of chromium, which is a critical element in both Inconel 690 and MA758; and

- Oxide scale formation and characteristics.

In order to achieve a reasonable extent of alteration, corrosion tests are typically performed over a one-week duration. Over this extended time at high temperature, the loss of sulfur species from the melt due to volatilization can be significant. The time dependence of the $\mathrm{SO}_{3}$ concentrations were monitored under standard metal-glass corrosion experiment conditions 
for glasses HLW-NG-Fe2 and HLWS-09. As shown in Figure 3.1, during the standard metal corrosion procedure with the glass melt open to air, sulfate concentrations dropped rapidly within hours at $1150^{\circ} \mathrm{C}$, then decreased more slowly in the two test glasses. For example, more than $70 \%$ of sulfate was lost within 12 hours from glass HLWS-09. Over longer test periods, nearly $85 \%$ or $92 \%$ of the $\mathrm{SO}_{3}$ was lost after 24 and 48 hours, respectively. Part of the sulfate loss can be compensated by periodic replenishment of test glass [40]. However, it is not practical to maintain a constant sulfate concentration via frequent glass replacement with such a rapid volatilization rate. As a compromise, in the initial tests of HLWS-09 and HLW-NG-Fe2, the glass was replaced after the second and fourth days of testing. In addition, however, a new method was developed to conduct the metal corrosion experiment in a sealed crucible. As described in Section 1.6.2, the sealed metal corrosion experiments used a larger covered alumina crucible to confine the test Pt-crucible and metal coupon. The lid of the larger alumina crucible was sealed with a nepheline melt that is very viscous at the test temperature, which acts as a sealant to suppress gas exchange in and out of the crucible while still allowing release of gas to prevent pressure build-up at the test temperature.

Table 3.2 summarizes the corrosion tests performed in this work and the corresponding test conditions. HLW-NG-Fe2 was tested only by the standard open crucible method with periodic glass replacement. HLWS-27 was tested only by the sealed crucible method. HLWS-09 with the highest $\mathrm{SO}_{3}$ content was tested by both open and sealed crucible methods. As shown by XRF analysis of $\mathrm{SO}_{3}$ in the glass samples (Table 3.3), the problem of sulfate loss was largely or completely mitigated by the sealed double crucible method for HLWS-09 and HLWS-27. In order to assure that the atmosphere within the sealed crucible had not become overly reducing, the iron redox state was analyzed for the HLWS-27 glass sample after 7-day MA758 corrosion test in a sealed crucible. The results from Mossbauer spectroscopy analysis indicated that virtually all of the iron was in the oxidized ferric state in general agreement with typical iron redox states measured in HLW glasses produced in melter tests.

\subsection{Metal Corrosion in HLW-NG-Fe2}

Standard metal corrosion tests were performed on both Inconel 690 and MA758 in contact with the HLW-NG-Fe2 glass melt at $1150^{\circ} \mathrm{C}$ for seven days (Table 3.2). The test glass was replenished after the second and fourth days to restore the sulfate concentration. The test results for the two Ni-Cr super alloys are reported below.

\subsubsection{Inconel 690 Corrosion in HLW-NG-Fe2}

HLW-NG-Fe2 was developed for the high-iron C-106/AY-102 waste. As listed in Table 3.1, the test glass sample (10W-G-116) is rich in $\mathrm{Fe}_{2} \mathrm{O}_{3}$ with moderate amounts of $\mathrm{Cr}_{2} \mathrm{O}_{3}$ and $\mathrm{NiO}$, but relatively low in $\mathrm{SO}_{3}$. Although sulfate loss could be significant (Table 3.1, Figure 3.1), for a $0.36 \mathrm{wt} \%$ target $\mathrm{SO}_{3}$ concentration and periodic replenishment of glass melt, the overall corrosion damage incurred by the test alloys (both Inconel 690 and MA758) are probably not as strongly influenced by the sulfate loss as would have been the case for the higher-sulfate glasses HLWS-09 and HLWS-27 (1.6 wt $\%$ and $\sim 1 \mathrm{wt} \% \mathrm{SO}_{3}$, respectively). As listed in Table 3.4, the 
dimensional changes of the Inconel 690 coupon are minimal, with 1 mil $(25.4 \mu \mathrm{m})$ loss at the neck region and negligible dimensional loss at the half-down region. Representative SEM images of Inconel 690 after a 7-day corrosion test in HLW-NG-Fe2 are shown in Figure 3.2. A schematic diagram of a typical metal coupon after corrosion testing is provided in Figure 3.3 in which the neck and half-down locations are identified. The assessment of the metal corrosion damage, based on SEM images and EDS analysis, is summarized in Table 3.4 at the neck and half-down locations in the test coupon. The internal oxidation and structural damage of Ni-Cr super alloys are typically reflected in the grain boundary damage and selective depletion of chromium from the interior of the alloy. Grain boundary damage, as revealed by SEM, is generally evident with numerous pitted pockets near the surface and the development of occlusions of oxide phases up to several hundred microns from the remaining surface of the coupon (Figure 3.2). The depletion of chromium from Inconel 690 was identified from the SEM/EDS line scans and point analyses that were collected near the neck and half-down locations perpendicular to the coupon surface. As shown in Figure 3.4 and summarized in Table 3.4 , the Inconel 690 coupon lost 30\% (at neck) to 50\% (at half-down) of the chromium near the surface, with the depleted region extending up to 300 microns deep. The line scan data for $\mathrm{Cr}$ depletion were confirmed by more precise (but more time consuming) SEM/EDS point analysis in the region near the surface (Figure 3.4). The $\mathrm{Cr}$ concentration in $\mathrm{Ni}-\mathrm{Cr}$ alloys is one of the critical parameters for corrosion resistance of the metal under high temperature oxidizing conditions. The metal corrosion rate accelerates significantly once its chromium concentration drops below a critical value $(\sim 20 \mathrm{wt} \%)$, often leading to catastrophic failure of the metal component. As shown in Figure 3.4, Inconel 690 was sensitized with considerable loss of $\mathrm{Cr}$ content up to a depth of 300 microns. The Cr content near the metal surface at the half-down region is about $15 \mathrm{wt} \%$ (as compared to the original $\mathrm{Cr}$ content of $\sim 30 \mathrm{wt} \%$ ) and about $22 \mathrm{wt} \%$ at the neck region.

\subsubsection{MA758 Corrosion in HLW-NG-Fe2}

The MA758 coupon after 7-day corrosion testing displayed no visible dimension loss and considerably less interior structural damage and $\mathrm{Cr}$ depletion than what was observed for the Inconel 690 coupon. Analysis of the interior structure from SEM images (Figure 3.5) and chemical compositions from SEM/EDS (Figure 3.6) are summarized in Table 3.4. In addition to less grain boundary damage at the half-down region, the most notable improvement from Inconel 690 to MA758 is the considerably lower Cr depletion, which ranges from $26-27 \mathrm{wt} \%$ in the neck and half-down regions.

Grain boundary damage from SEM imaging (Figure 3.5) often appears as isolated occlusions of oxide phases within the MA758 coupon, which is in clear contrast to the formation of continuous channels along the grain boundaries inside Inconel 690. This suggests that the grain-boundary strengthened mechanical alloying used in MA758 is effective against glass attack under these test conditions. 


\subsection{Metal Corrosion in HLWS-09}

HLWS-09 glass was formulated for a projected high sulfur HLW stream from HTWOS Model Run (Batch 4028) [26]. At the nominal waste loading of $28 \mathrm{wt} \%$, the formulation has a target sulfate concentration of $1.20 \mathrm{wt} \% \mathrm{SO}_{3}$. However, subsequent melter testing showed that this formulation showed no sulfate salt formation even at a waste loading of $38 \mathrm{wt} \%$. Consequently, the actual test glass samples contain $1.64 \mathrm{wt} \% \mathrm{SO}_{3}$ (Table 3.1) to reflect the highest attainable $\mathrm{SO}_{3}$ concentration for this formulation.

Corrosion of Inconel 690 and MA758 alloys were tested in the HLWS-09 glass melt in two different environments. As listed in Table 3.2, the first set of corrosion tests were conducted per the standard metal corrosion method with periodic glass replenishment, as was done for HLW-NG-Fe2. The second set of corrosion tests were conducted using a modified two-crucible setup as described in Section 1.6.2. The sealed crucible corrosion test was designed to minimize or eliminate the rapid volatilization of sulfur from the HLW glass melt at the test temperature. Overall, the two crucible setup was very effective in retaining $\mathrm{SO}_{3}$ in the glass melt for the duration of the test. The results of two sets of metal corrosion tests allowed the direct comparison of metal corrosion in the same HLW melt at two different sulfate concentrations.

\subsubsection{Inconel 690 Corrosion in HLWS-09}

The major results from the corrosion test of Inconel 690 in the HLWS-09 melt are given in Table 3.4. It is apparent that the periodic glass replacements in an open crucible was not sufficient to maintain adequate sulfate concentration in the glass melt (Table 3.3), which in turn resulted in very different corrosion characteristics.

The dimension loss of the test coupon in the half-down region is negligible for the open crucible test but was $1 \mathrm{mil}(25.4 \mu \mathrm{m})$ from the sealed crucible test. The corresponding losses at the neck region are $6 \mathrm{mil}(152.4 \mu \mathrm{m})$ and 4 mil $(101.6 \mu \mathrm{m})$, respectively. Cr depletion and the accompanying inter-granular damage are greatly accelerated in the sealed crucible test in which the $\mathrm{SO}_{3}$ concentration was maintained (Table 3.3). As shown in Figures 3.7 and 3.8 and Table 3.4 , the grain boundary damage in the Inconel 690 coupon from the sealed crucible test is approximately two times as deep as that in the coupon from the open crucible test at both the neck and half-down regions. The $\mathrm{Cr}$ concentration near the surface of the test coupons decreased from $31 \mathrm{wt} \%$ of the pristine alloy to only $6 \mathrm{wt} \%$ at half-down and $8 \mathrm{wt} \%$ at the neck of the coupon from the sealed crucible test in comparison to $18 \mathrm{wt} \%$ at half-down and $10 \mathrm{wt} \%$ at the neck of the coupon from the open crucible test. The sensitization of the Ni-Cr alloy in response to apparently different $\mathrm{SO}_{3}$ contents is clearly shown in Figures 3.9 and 3.10. Although the depths of Cr-depletion are similar in coupons from both tests, the overall $\mathrm{Cr}$ losses and the resultant concentration gradients are worse for the Inconel 690 coupon from the sealed crucible test. 


\subsubsection{MA758 Corrosion in HLWS-09}

Overall, MA758 displayed considerably less damage than Inconel 690 under both test conditions. The dimensional losses are negligible at the half-down regions of the coupons from both tests. At the neck regions, 1 mil $(25.4 \mu \mathrm{m})$ loss was observed for the coupon from the open crucible test but no loss was measurable for the coupon from the sealed crucible test. The effect of higher sulfate content in the sealed crucible test is most noticeable in the interior grain boundary damage near the half-down region. As shown in Figures 3.11 and 3.12 and Table 3.4, a zone as much as 185 microns deep was observed with internal oxidization along the grain boundaries of the MA758 coupon from the sealed crucible test, while that zone was only a third as deep for the coupon from the open crucible test. On the other hand, the difference in the depth of grain boundary damage did not correlate with SEM/EDS analysis of Cr concentrations in the MA758 test coupons. As shown in Figures 3.13 and 3.14, the concentration profiles of $\mathrm{Cr}$ inside the two metal coupons are virtually identical. It is interesting that both the grain structure and the surface $\mathrm{Cr}$ concentration are considerably better preserved in the neck region in the metal coupon from the sealed crucible test in spite of the higher sulfate concentration of the glass melt.

\subsection{Metal Corrosion in HLWS-27}

HLWS-27 glass was formulated for a projected high sulfur HLW stream from HTWOS Model Run (Batch 1925) [36]. As documented in the Test Plan [25], this sulfate-rich waste stream is also rich in many spinel-prone oxides, including $\mathrm{Cr}, \mathrm{Mn}$, and $\mathrm{Ni}$. In particular, on an oxide basis, equal concentrations of $\mathrm{SO}_{3}$ and $\mathrm{Cr}_{2} \mathrm{O}_{3}$ are present in the product glass. The compositions of the target glass HLWS-27 and its crucible melt (HLWS-27R1) are listed in Table 3.1. The $\mathrm{SO}_{3}$ concentration at saturation is $1.54 \mathrm{wt} \%$ at $1150^{\circ} \mathrm{C}$ as determined by the gas bubbling method. However HLWS-27 was developed at below this sulfate concentration in order to meet all processing and product quality requirements. The practical sulfate loading limit in a scaled melter test was determined to be around $1.1 \mathrm{wt} \% \mathrm{SO}_{3}$. HLWS-27 with a target $\mathrm{SO}_{3}$ concentration of $0.95 \mathrm{wt} \%$ (the target concentration used in crucible melt) was chosen for the metal corrosion tests.

The corrosion of Inconel 690 and MA758 alloys in HLWS-27 glass melt was tested in a modified two crucible setup as described in Section 1.6.2. Corrosion testing in an open crucible was not performed for HLWS-27.

\subsubsection{Inconel 690 and MA758 Corrosion in HLWS-27}

The results of metallurgical examinations of the coupons are similar for Inconel 690 and MA758 after 7-day corrosion experiments in sealed crucibles. As listed in Table 3.4, both alloys experienced negligible dimensional loss and had less than 100 micron deep grain boundary damage at both the neck and half-down regions (Figures 3.15 and 3.16). The degrees of $\mathrm{Cr}$ depletion are also similar for the two alloys, with near surface $\mathrm{Cr}$ concentrations ranging from 22-24 wt\% for Inconel 690 and from 25-27 wt\% for MA758 (Figures 3.17 and 3.18). A detailed comparison of the $\mathrm{Cr}$ concentration profiles of the two alloys at the half-down regions revealed that $\mathrm{Cr}$ depletion in MA758 coupon is noticeably less (Figure 3.19). 
It is instructive to compare the XRF analysis of HLWS-27 glass samples before and after the metal corrosion experiments. Aside from the nearly constant $\mathrm{SO}_{3}$ concentration due to the improved test method, the most remarkable features are the large decreases in $\mathrm{Cr}_{2} \mathrm{O}_{3}$ concentration (more than 50\%) in the two glass samples after 7-day corrosion tests (Table 3.3). Although $\mathrm{Cr}$ is one of the most important components in $\mathrm{Ni}-\mathrm{Cr}$ super alloys, $\mathrm{Cr}_{2} \mathrm{O}_{3}$ concentrations in the test glass samples are normally constant, as was observed for samples of HLW-NG-Fe2 and HLWS-09 glass melts (Table 3.3). One possible explanation for the drop in $\mathrm{Cr}_{2} \mathrm{O}_{3}$ concentration is the presence of crystalline spinel in the starting sample of HLWS-27R1. An XRD powder pattern of a sample of HLWS-27R1 indicates minor amounts of spinel in the starting glass melted at $1150^{\circ} \mathrm{C}$. Therefore, $0.92 \mathrm{wt} \% \mathrm{Cr}_{2} \mathrm{O}_{3}$ as analyzed by $\mathrm{XRF}$ includes the contribution from crystalline spinel. At approximately two times the glass density, $0.5 \mathrm{wt} \%$ $\mathrm{Cr}_{2} \mathrm{O}_{3}$ translates to about $0.3-0.4$ vol\% chromite (including both $\mathrm{FeO}$ and $\mathrm{Cr}_{2} \mathrm{O}_{3}$ ) in the glass. It is conceivable that the suspended spinel crystals may have separated from the main body of the glass melt either via settling to the bottom of the crucible or by adhering to the surface of the reacting metal coupons. Consequently, the $\mathrm{Cr}_{2} \mathrm{O}_{3}$ concentrations $(w t \%)$ from XRF analysis of the glasses after the corrosion tests likely represented the actual glass composition without the crystalline spinel. XRD analysis of these two glass samples after corrosion tests showed only trace amounts of spinel. More importantly, the presence of $\mathrm{Cr}$-rich spinel could have greatly influenced the corrosion of the two Ni-Cr alloys. It is likely that the oxidization and dissolution of the key alloy component $\mathrm{Cr}$ would have been hampered in a test coupon in contact with a glass melt that is already over-saturated with the Cr-rich spinel. It is also likely that part of the $\mathrm{Cr}_{2} \mathrm{O}_{3}$ phase found adhered to the surface of the test metal coupon originated from the Cr-rich spinel suspended in the glass (Figures 3.15 and 3.16). Therefore, the metal corrosion test results with HLWS-27 glass melt are likely influenced by the unusually high $\mathrm{Cr}_{2} \mathrm{O}_{3}$ content in the bulk glass, which could also explain the very similar corrosion test results for MA758 and Inconel 690 for this glass.

\subsection{Evaluation of Corrosion of Inconel 690 and MA758 in S-rich HLW Glass}

As discussed in Section 3.1, while the dimension loss is the most straightforward measure of the potential service life of an alloy, this parameter presents a number of issues and limitations in the interpretation of results from small-scale coupon tests with limited durations. Even in actual service, the dimension loss can be minimal but the internal damage to the alloy can result in such extensive degradation of its native properties as to render it unfit for service (e.g., grain growth and embrittlement and/or chromium loss and loss of passivation). Accordingly, it is important to supplement the simple dimension loss measurements with other information, as was done in the present work.

As shown in Table 3.4, the measured coupon dimension losses near the glass surface (neck) and at the half-down locations are essentially all negligible $(\leq 1 \mathrm{mil}(25.4 \mu \mathrm{m}))$, with the exception of Inconel 690 in sulfate-rich HLWS-09 glass, in which the neck region dimension losses were measured at 6 mil $(152.4 \mu \mathrm{m})$ and 4 mil $(101.6 \mu \mathrm{m})$ for tests in the open and sealed crucibles, respectively. The highest dimension loss value corresponds to about 0.3 inch per year. However, as noted above, this addresses only one aspect of the corrosion process. 
Internal damage to the alloy includes effects due to grain boundary damage and the associated internal oxidation, de-alloying/sensitization and, in particular, the selective depletion of $\mathrm{Cr}$, and scale characteristics such as phase assembly, thickness, scale integrity, etc. As proposed in previous studies of Inconel 690 corrosion $[9,10]$, in addition to dimension loss, the degree of Cr-depletion provides a useful indicator of the glass corrosion damage for the $\mathrm{Ni}-\mathrm{Cr}$ super alloy. The chromium content of the super alloys is a critical contributor to its corrosion resistance and in protecting the alloy from the strongly oxidizing molten glass solvent [47]. Metal corrosion increases as the chromium content falls and accelerates drastically once the chromium content in the alloy falls below about $20 \mathrm{wt} \%$ [47].

As given in Table 3.4, the Cr-depletion depths after the 7-day corrosion tests are around 300 microns at the half-down region for all of the eight corrosion test coupons reported in this work. Similarly, the Cr-depletion depths are around 300 microns at the neck region except for the coupons in HLWS-09, which are about 50 microns deeper. In contrast, the near surface $\mathrm{Cr}$ concentrations varied considerably in spite of the rather similar depths of $\mathrm{Cr}$ depletion. The loss of $\mathrm{Cr}$ would inevitably weaken the resistance of the alloys to molten glass attack and result in more extensive structural damage with time. Considering the critical role of $\mathrm{Cr}$ in resisting the oxidation of Ni-Cr super alloys, the measured near surface $\mathrm{Cr}$ concentrations were therefore used to evaluate the corrosion damage of the two Ni-Cr super alloys. The key observations are summarized below:

- $\quad$ Sulfate Effect: From HLWS-09 corrosion experiments, higher sulfate concentrations in the sealed crucible experiments increased the depletion of $\mathrm{Cr}$ in the Inconel 690 coupon in comparison to that for the open crucible (Figures 3.9 and 3.10). In sharp contrast, MA758 coupons retained its near surface $\mathrm{Cr}$ content in both tests (Figures 3.13 and 3.14)

- Glass Effect: Inconel690 showed the highest Cr loss in the HLWS-09 glass melt (sealed crucible test), followed by HLW-NG-Fe2 and HLWS-09 tested in an open crucible. The spinel-oversaturated HLWS-27 glass melt caused the least damage to Inconel 690. In clear contrast, MA758 showed much less corrosion in all three glass melts.

- Alloy Effect: In all paired tests of the three glasses and two test methods, MA758 alloy consistently outperformed Inconel 690 in resisting $\mathrm{Cr}$ depletion and, in some cases, also in dimension loss (for HLW-NG-Fe2 and HLWS-09 open-crucible test).

- Overall: Corrosion tests with HLWS-09 glass melt in the sealed crucible tests that maintained the high sulfate concentration posed the toughest challenge to both $\mathrm{Ni}-\mathrm{Cr}$ alloys. Inconel 690 coupon lost $80 \%$ of its surface $\mathrm{Cr}$ at the half-down region in addition to 4 mil $(101.6 \mu \mathrm{m})$ neck loss. However, MA758 showed no dimension loss with $\mathrm{Cr}$ depletion of only about $20 \%$ at the half-down region. 


\section{SECTION 4.0 MELTER OPERATIONS}

Melter tests were conducted on the DM10 with the HLW high sulfur Batch 1925 waste simulant and the newly developed HLWS-27 glass formulation at various feed sulfur concentrations between $5 / 29 / 13$ and $6 / 5 / 13$. These tests produced nearly $100 \mathrm{~kg}$ of glass from almost $300 \mathrm{~kg}$ of feed. Feed processed, sulfur concentrations, production rates, and measured melter parameters for the tests are summarized in Table 4.1. The sulfur content of the feed was adjusted by the addition of concentrated sulfuric acid to the nominal feed. The tests were nominally 20 hours in duration and were distinguished by differences in feed sulfur content as follows:

- A: Target $\mathrm{SO}_{3}$ concentration of $0.953 \mathrm{wt} \%$

- B: Target $\mathrm{SO}_{3}$ concentration of $1.3 \mathrm{wt} \%$

- C: Target $\mathrm{SO} 3$ concentration of $1.5 \mathrm{wt} \%$

- D: Target SO3 concentration of $1.78 \mathrm{wt} \%$

- E: Target $\mathrm{SO}_{3}$ concentration of $1.63 \mathrm{wt} \%$.

Attempts were made to replicate the melter configuration and operating conditions used for previous melter tests with HLW simulants [16, 19, 20, 22, 23, 26, 29-35, 38]. These conditions include a near complete cold cap, which is between $80-95 \%$ melt surface coverage for the DM10 since a 100\% cold cap tends to lead to "bridging" in smaller melters. The bubbling rate was adjusted to approximate a feed rate of $3 \mathrm{~kg} / \mathrm{hr}$ (glass production rate of $1100 \mathrm{~kg} / \mathrm{m}^{2} /$ day) and to provide the desired complete cold cap (90-100\% of melt surface covered with feed). Power was supplied to the electrodes to target a glass temperature of $1150^{\circ} \mathrm{C}$ throughout the tests. This approach permitted the direct comparison of results between current and previous tests with respect to the onset of secondary phase formation. The glass pool was sampled a minimum of three times in separate locations at the end of each test segment to detect the presence of secondary phases. If secondary phases were detected, the melt pool was bubbled and sometimes fed water, then sampled again to verify the removal of the secondary phase prior to performing the following test segment or melter shut down.

Throughout the tests, the feed was easily processed without clogs or feeding disruptions. The cold cap was observed through a view port on top of the melter over the duration of the tests. No significant foaming was visible during the tests. Changes in bubbling rate were made in each test in response to observations of the cold cap in order to maintain the desired feed rate.

\subsection{Melter Operations Data}

The test average feed rates ranged between 2.7 and $3.0 \mathrm{~kg} / \mathrm{hr}$, yielding glass production rates between 1000 and $1119 \mathrm{~kg} / \mathrm{m}^{2} /$ day. Glass temperatures 2 and 4 inches from the melt pool 
The Catholic University of America Vitreous State Laboratory

floor averaged within $10^{\circ} \mathrm{C}$ and $15^{\circ} \mathrm{C}$ of the target glass temperatures throughout most of the tests, respectively. The glass temperature 4 inches from the melt floor averaged 10 to $20^{\circ} \mathrm{C}$ lower than the temperature measured 2 inches from the melt floor and varied more with the level of glass in the melter and changes in the cold cap than did the temperatures measured lower in the melt pool. Electrode temperatures were about $100^{\circ} \mathrm{C}$ lower than the temperature of the glass pool. The discharge temperature was maintained above $1000^{\circ} \mathrm{C}$ throughout most of the tests to facilitate glass discharge. Plenum temperature measurements averaged between 500 and $550^{\circ} \mathrm{C}$, indicating a relatively complete cold cap during testing. The exposed and thermowell thermocouple readings were very similar throughout testing with the exposed thermocouple temperature being only up to $15^{\circ} \mathrm{C}$ higher than the temperature in the thermowell. The gas temperature at the film cooler averaged between $284-292^{\circ} \mathrm{C}$, which results from the combined effects of the plenum temperature, the amount of added film cooler air, and the temperature of the added film cooler air. Test average glass pool resistance ranged between 0.187 and 0.201 ohms, which is in the middle of the range measured in recent DM10 tests with HLW glass compositions [26]. Test average bubbling rates ranged from $1.4-1.9 \mathrm{lpm}$, again in the middle of the range measured in recent DM10 tests with HLW glass compositions [26]. A vacuum of about 1 inch of water was maintained on the melter throughout the tests. Test average power supplied to the electrodes ranged between 4.9 and $5.2 \mathrm{~kW}$ throughout testing, consistent with the relatively constant feed rate and feed water content used throughout the tests.

\subsection{Secondary Phase Formation}

The primary objective of these melter tests was to determine the maximum amount of sulfur that could be processed in the feed and retained in the glass product without forming secondary phases for the HLW high sulfur Batch 1925 waste simulant and HLWS-27 glass formulation. The results are summarized in Table 4.1 and displayed in Figure 4.1. The sulfur content of the feed was adjusted for each test segment by the addition of sulfuric acid to the feed. The feed concentration of sulfur was increased progressively over four test segments from 0.953 to $1.3,1.5$, and $1.78 \mathrm{wt} \% \mathrm{SO}_{3}$ on a glass basis until a secondary sulfur phase was observed on the melt pool surface as observed in at least two of three dip samples. The secondary phase was removed from the melt surface by bubbling the melt pool while feeding water. Subsequently, the melter was fed $1.63 \mathrm{wt} \% \mathrm{SO}_{3}$ on a glass basis without the formation of secondary phases. The concentration of sulfur in the glass increased from $0.4 \mathrm{wt} \% \mathrm{SO}_{3}$ at the onset of testing to about $1.25 \mathrm{wt} \% \mathrm{SO}_{3}$ when a secondary phase was observed on the melt pool surface. Once testing was resumed targeting a sulfur content of $1.63 \mathrm{wt} \% \mathrm{SO}_{3}$, the concentration of sulfur in the glass reached a steady state of $1.13 \mathrm{wt} \% \mathrm{SO}_{3}$ without the formation of secondary sulfur phases. The lack of secondary phase during the final test and the secondary phase observed in the second to last test indicate that the limiting feed sulfur concentration is between 1.63 and $1.78 \mathrm{wt} \% \mathrm{SO}_{3}$. The high sulfur tolerance of this formulation, which rivals many LAW formulations, is noteworthy, particularly in comparison to the present WTP limit of $0.44 \mathrm{wt} \% \mathrm{SO}_{3}$ [37] and the ORP System Plan 6 limit of $0.5 \mathrm{wt} \% \mathrm{SO}_{3}$ [36] for HLW glass.

During DM10 melter tests, the maximum level of sulfur in the glass without the formation of secondary phases was $1.13 \mathrm{wt} \% \mathrm{SO}_{3}$, which is significantly less than the 1.43 and 
$1.54 \mathrm{wt} \% \mathrm{SO}_{3}$ levels measured in batch saturation and bubbling tests (see Section 2.3.2). Secondary phase formed at $\mathrm{SO}_{3}$ contents much lower than the equilibrium solubility values for two of three HLW compositions recently tested [26] as well as for some high sulfur LAW feeds. While processing melter feeds with very high sulfate concentrations, a molten sulfate salt phase forms in the cold-cap region during processing. This phase may exist as transient droplets or be sufficiently extensive to produce a separate salt phase that becomes mechanically disengaged from the rest of the cold cap. Once formed, the salt phase is slow to dissolve into the underlying glass melt; consequently, the salt phase typically forms before the underlying glass melt is saturated with sulfate $[1,3,4,48,49,50]$. If the feed rate is sufficiently low (which is clearly undesirable), the equilibrium sulfate saturation concentration in the glass can be approached more closely before a separate salt phase forms. However, in general, as the feed rate is increased, for the same sulfate concentration in the feed, the salt phase appears progressively earlier. Thus, in practice, the formation of a sulfate phase is governed by both thermodynamic and kinetic factors and, therefore, the effects of both must be considered in order to avoid the formation of such phases during operations. While the equilibrium sulfate solubility limit can be measured, the factors that control the kinetics of sulfur incorporation into the glass melt are not well understood. Some glass compositions are able to reach sulfate concentrations close to the equilibrium solubility limits before secondary sulfate phases form, whereas such phases form at much lower concentrations in other compositions. 


\section{SECTION 5.0 \\ MELTER FEED, GLASS AND EXHAUST ANALYSIS}

\subsection{Analysis of Melter Feed}

The high sulfur waste simulant was produced at VSL from reagent grade chemicals. The feed for the HLWS-27 formulation was produced by the addition of boric acid, lithium carbonate, wollastonite, and silica to the simulant (see Table 2.7) in the calculated proportions for each test. Calcium was added to the simulant as calcium carbonate instead of calcium oxide due to the availability of chemicals and sodium was then added to the simulant exclusively as sodium hydroxide, instead of sodium carbonate, to correct the carbonate content. Feed sampled from the stock batch produced for testing and feed remaining from the end of testing was analyzed to determine physical properties and confirm the chemical composition.

Measured properties and analyzed chemical compositions of the feed samples are compared to the targets in Tables 5.1 and 5.2. The measured feed solids contents were all within about three percent of the calculated target value validating the use of target values for calculating feed rates. Measured density, water content, and glass content are relatively similar between the samples illustrating the consistency of the feed over the course of the tests. There is a slight enhancement in solids content in feed sampled from the feed tank at the end of testing suggesting a minor accumulation of solids during testing. Boron and lithium concentrations measured by DCP were within seven and six percent of their respective target values for the melter feed for all three compositions, validating the use of the target values for normalizing the XRF data. In the feed samples taken from the stock batch, all oxides targeted at greater than one weight percent were within ten percent of the target composition except for bismuth and aluminum. Analysis of glass produced from residual feed from testing indicated bismuth, iron, manganese, and sulfur oxides deviated from target by more than ten percent for oxides targeted at greater than one weight percent. For glass discharged from the melter tests, only bismuth and sulfur deviated from target by more than ten percent once the glass pool was fully turned over (see Section 5.2). Collectively, the compositional analysis indicate excess bismuth in the feed of about 0.2 to 0.3 absolute weight percent related to either a higher than reported purity of bismuth used in the simulant or a high analytical bias for bismuth. Similar surpluses of bismuth have previously been observed in feed [26] and are not expected to affect the objectives of the present tests. Deviations of aluminum, iron, and manganese observed in some of the samples can be attributed to sampling and settling out of heavy minerals and therefore do not reflect the actual composition of the feed. Several oxides targeted at low concentrations including $\mathrm{Mg}, \mathrm{Ni}$, and $\mathrm{Zr}$, were observed in the feed sample analysis at higher concentrations due presumably to trace level contamination. Sulfur concentrations are below target in feed samples due to volatilization during crucible melting, as expected. 


\subsection{Discharge Glasses}

Nearly one hundred kilograms of glass was produced in these tests. The glass was discharged from the melter periodically using an airlift system and collected in custom fabricated square carbon steel cans. The discharged product glass was inspected for secondary phases, and sampled by removing sufficient glass from the top of each can for total inorganic analysis. No macroscopic secondary phases were observed on any of the discharge glasses. Listings of product glass masses, sample names, and discharge dates are provided in Table 5.3.

Discharge glass samples were crushed and analyzed directly by XRF. The target values for boron and lithium oxides, which are not determined by XRF, and DCP analyzed concentrations of select glasses were used to calculate boron and lithium concentrations and for normalizing the XRF data to $100 \mathrm{wt} \%$. The XRF analyzed compositions of all discharged glass samples are provided in Tables 5.4 - 5.8. The majority of the XRF analysis results compared favorably to the target values and also corroborated much of the feed sample analysis (see Section 5.1.). Of the oxides with a target concentration of one percent or greater, the XRF values were all within $10 \%$ of the target values except for bismuth and sulfur once the glass pool was fully turned over to the HLWS-27 composition (Test B). The deviations from target during Test A are attributable to the composition of the melt pool at the start of testing being different from the target composition. Minor constituents such as barium, chlorine, potassium, magnesium, titanium, and zinc were over represented in the glass product at about the same frequency and magnitude as in the feed samples (see Section 5.1). Oxides of cadmium, cerium, cesium, lanthanum, neodymium, tin, titanium, and zinc were present in the melt pool at the onset of the test. The discharge glass compositions over the course of testing are illustrated in Figures 5.1 5.5. Most oxides approximate their respective target or analyzed feed values and varied little during testing after the production of $30 \mathrm{~kg}$ of glass. At the beginning of testing, the major oxides of $\mathrm{Al}, \mathrm{Bi}, \mathrm{Ca}, \mathrm{Mn}, \mathrm{P}, \mathrm{Si}$, and $\mathrm{Sr}$ increase in concentration at the expense of $\mathrm{B}, \mathrm{Fe}, \mathrm{Li}, \mathrm{Zn}$, and $\mathrm{Zr}$ as the glass pool transitions to the HLWS-27 formulation. Oxides of cadmium, cerium, cesium, lanthanum, neodymium, and tin present in the melt pool at the onset of the test decrease in concentration over the course of testing to non-detectable concentrations.

\subsection{Glass Pool Samples}

The glass pool samples were obtained by dipping a rod into the glass melt at the end of each test to detect any secondary phases on the glass pool surface, to verify the composition of the glass pool, and to determine the melt level to quantify the amount of glass in the melt pool. A list of all dip samples including sample names, sampling dates, glass pool depth, and secondary phase observations are given in Table 5.9. A minimum of three dip samples at three locations in the melt pool were taken to fully characterize the melt pool surface for secondary phases. Samples were also taken prior to each test and after bubbling periods for removing secondary phases to verify the lack of secondary phases on the melt surface prior to subsequent testing. There was visual evidence of secondary phases in dip samples taken at the end of Test D after processing feed targeting $1.78 \mathrm{wt} \% \mathrm{SO}_{3}$ on a glass basis. Pictorial examples of the secondary phase are given in Figures 5.6(a) and 5.6(b). The secondary phase on the melt pool surface 
adheres to and coats the threaded rod and is subsequently partially coated with glass. The full extent of the secondary phase was observed upon removal of glass, as shown in Figure 5.6(b). Lesser amounts of secondary phase were observed on a single sample prior to Test $\mathrm{D}$ due to the lower temperature idling over the preceding 50 hours. The melt pool temperature was increased to the processing temperature, bubbled, and resampled to demonstrate a lack of secondary phase prior to Test D. No secondary phases were associated with any other tests. The significance of the secondary phase observations with respect to sulfur concentrations and solubility is detailed in Section 4.2. The analysis of the glass pool samples corroborates the composition of the discharge glasses, as shown in Table 5.10. Comparison of the analyzed compositions of dip samples taken prior to and after each test with each glass formulation further demonstrates the changes in composition of the melt pool during each test series.

\subsection{Gases Monitored by FTIR}

Melter emissions were monitored in each test for a variety of gaseous components, most notably $\mathrm{CO}$ and nitrogen species, by Fourier Transform Infra-Red Spectroscopy (FTIR). The off-gas system temperature is maintained well above $100^{\circ} \mathrm{C}$ beyond the sampling port downstream of the HEPA filter to prevent analyte loss due to condensation prior to monitoring. A summary of concentration averages and ranges monitored during each test is provided in Table 5.11. The analytes listed are those that were thought likely to be observed during the test based on previous work; no other species were detected in the off-gas stream by FTIR. Monitored emissions were a function of the nitrogen oxide, organic carbon, and water content in the feed and the feed rate. The feed content of nitrogen oxides and organic carbon is very low in this waste stream and therefore the monitored emissions of nitrogen oxides and byproducts of incomplete combustion are uniformly very low or are below detectable levels. The percent moisture in the exhaust averaged between 1.7 and 2.4. The most abundant nitrogen species monitored was NO, which is consistent with previous tests in which nitrates and nitrites were present in the feed. Off-gas particulate sampling was not conducted for these tests but will be included as part of the off-gas analysis for future scale-up testing on the DM100 or DM1200 melters. 


\section{SECTION 6.0 SUMMARY AND CONCLUSIONS}

Tests were conducted at the crucible scale and on the DM10 melter to measure sulfur solubility and to determine maximum feed sulfur concentrations that can be processed without the formation of secondary sulfate phases for a projected high sulfur HLW stream. A glass formulation for a high sulfur HLW waste stream was developed, evaluated for sulfur solubility by two different methods at crucible scale (over-batching and gas bubbling), and processed at various sulfur contents on the DM10 melter system. In addition, three different HLW glass compositions containing high concentrations of sulfur were tested to determine the extent to which each corrodes two different $\mathrm{Ni}-\mathrm{Cr}$ alloys used to fabricate melter components.

A glass composition (HLWS-27) was developed for a projected high sulfur HLW stream (HTWOS Model Run, Batch 1925) with a waste loading of $52 \mathrm{wt} \%$ and a target sulfur concentration of $0.95 \mathrm{wt} \% \mathrm{SO}_{3}$. A variety of additive blends were tested to identify a glass with high sulfur solubility while meeting all of the processing and product quality requirements for WTP HLW glass. Melter tests were conducted with the high sulfur HLW simulant and the HLWS-27 glass formulation at various feed sulfur concentrations on the DM10 melter. The highest sulfur feed concentrations and waste loadings that could be processed through the DM10 without the formation of secondary sulfate phases were determined. These tests produced nearly $100 \mathrm{~kg}$ of glass from a projected high sulfur stream. In each of the five tests, the bubbling rate was adjusted to achieve a feed rate of $3 \mathrm{~kg} / \mathrm{hr}$ (about $1100 \mathrm{~kg} / \mathrm{m}^{2} /$ day), a complete cold cap, and a plenum temperature of $500-550^{\circ} \mathrm{C}$. Glass samples taken throughout the tests from the melt pool and the air-lift discharge were visually examined for secondary phases and analyzed for chemical composition. Glass samples were taken from the melt pool to detect secondary phases on the melt pool surface. The sulfur content of the feed was progressively increased to $1.63 \mathrm{wt} \% \mathrm{SO}_{3}$ on a glass basis, and a measured $\mathrm{SO}_{3}$ content of $1.13 \mathrm{wt} \%$ in the glass product, without any observations of secondary sulfur phases. Testing at higher feed and glass sulfur levels resulted in the formation of secondary phases. Therefore the processing limits for sulfur content appear to be 1.63 and $1.13 \mathrm{wt} \% \mathrm{SO}_{3}$ for the feed and glass, respectively, which is significantly lower than the $1.54 \mathrm{wt} \% \mathrm{SO}_{3}$ saturation level for glass measured in the crucible-scale bubbling tests.

Inconel 690 and MA758, two high performance, Ni-Cr superalloys were tested in this work for their corrosion characteristics in three sulfur-bearing HLW glasses developed to accommodate the projected high sulfate contents in Hanford HLW. The tests were performed at $1150^{\circ} \mathrm{C}$, which is the nominal melter operating temperature. From a test matrix of three formulations and two test conditions (open vs. sealed crucible), the sulfur-rich HLWS-09 (in both the open and the sealed crucible tests) caused the greatest extent of metal damage, likely due to its considerably higher sulfur content. The detrimental effects are most evident in the severe depletion of $\mathrm{Cr}$ from the $\mathrm{Ni}-\mathrm{Cr}$ alloys resulting in a sensitized surface zone as well as the development of deep oxidation along the grain boundaries. The $\mathrm{Cr}$ depletion near the alloy surface is most evident in the Inconel 690 test coupons in contact with HLWS-09 in open or sealed crucible tests. The considerably deeper $\mathrm{Cr}$ depletion observed in the sealed crucible test is 
attributable to the higher sulfur concentration retained in the HLWS-09 glass melt. In contrast to Inconel 690, mechanical alloy MA758 displayed robust corrosion resistance to these sulfur-rich HLW glass melts at different $\mathrm{SO}_{3}$ concentrations and behavior that is largely comparable to that in typical HLW borosilicate waste glasses [51]. Overall, the test results indicate that MA758 is a better choice than Inconel 690 in applications where the metal is in direct contact with sulfur-rich HLW melts.

It should be noted that the corrosion reactions between the $\mathrm{Ni}-\mathrm{Cr}$ super alloys and $\mathrm{HLW}$ glass melts can be strongly influenced by the concentration of key alloy components in the glass melt. As discussed in Section 3.3, the relatively minor damage observed for the Inconel 690 alloy in the HLWS-27 melt is probably due to the fact that the HLWS-27 glass melt was oversaturated with Cr-rich spinel before the metal corrosion tests. Consequently, the oxidation and dissolution of the key alloy components was limited by the solubility of chromium oxide or chromium-rich spinel in the host solvent. It is likely that the development of a $\mathrm{Cr}_{2} \mathrm{O}_{3}$ layer on the metal surface (substantially thicker than that from the other two glasses) was at least partially facilitated by the Cr-rich spinel phase already present in the glass. The formation of such a coating on the surface of the alloys would effectively shield the metal from further corrosion damage. Although the presence of spinel in glass melt at the melter processing temperature can be problematic with respect to melt discharge or deposition and accumulation on the melter floor, as has been observed previously, at low concentrations, spinel crystals of a few microns diameter may not jeopardize the continuous operation of an adequately agitated (via air bubbling) glass melter. Therefore, it may be worthwhile to explore further the benefits and risks of employing marginally spinel-saturated HLW melts as a means to counter the increased corrosion damage to metal components in high-sulfur HLW melts.

\subsection{Recommendations for Future Work}

The results of the testing presented herein show the range in sulfur solubility in HLW glasses and the potential for increasing the sulfur solubility through glass formulation design. The results also demonstrate that although sulfur solubility in glass defines the equilibrium amount of sulfur that can be retained in glass, solubility is not the only factor determining secondary sulfate phase formation while processing on a continuously fed melter since kinetic factors also play an important role. The test results further demonstrate that it is possible to develop HLW glass formulations that can tolerate significantly higher levels of sulfur than would be allowed by the present ORP System Plan 6 limit of $0.5 \mathrm{wt} \% \mathrm{SO}_{3}$ [36] and the WTP limit of $0.44 \mathrm{wt} \% \mathrm{SO}_{3}[37]$ in HLW glass. This work illustrates the potential for significant reductions in HLW canister count and HLW processing duration for sulfur-limited HLW streams, which are projected to account for some $22 \%$ of the HLW batches in the WTP mission [36]. Further work that is recommended in order to develop and demonstrate this potential for implementation into the WTP is outlined below.

- Increase Sulfur Solubility in Glass through Formulation Enhancements: Glass formulations with higher sulfur solubility, and thus higher waste loading, should be developed for HLW streams that are currently projected to be limited by sulfur solubility. 
This strategy would entail developing an approach with additive blends that can be applied to projected future waste streams with high sulfur contents. A model that relates sulfur solubility to glass composition would be a useful tool for implementing these enhancements into the WTP facility and it is recommended that such a model be developed. Increases in sulfur solubility through glass formulation must be balanced against other benefits of glass formulation enhancements such as glass production rate and compliance with relevant glass processing and product quality requirements for the WTP.

- Identification of Kinetic Factors Contributing to Secondary Sulfate Phase Formation: Testing should be performed to fully understand the factors responsible for secondary phase formation in HLW glasses at sulfur contents significantly below the measured sulfur solubility limit. Operational strategies need to be identified to mitigate such secondary sulfur phase formation. In particular, the interplay between processing rate and sulfate salt formation needs to be investigated.

- Other WTP HLW Feed Types: The testing to date has been based on a limited number of HLW compositions from the Hanford tanks. The work should be extended to address the full range of high-sulfur HLW feeds expected to be processed at the WTP. The HLW compositions evaluated to date also contain very limited amounts of nitrates and organic carbon.

- Scale-Up Testing: Since the formation of secondary sulfur phases is partly related to kinetic factors and can be thus affected by melt surface area, processing rate, and melt pool bubbling, larger scale testing should be performed to confirm the results from the crucible and the DM10 systems. Scale-up testing is also needed to resolve the observed processing rate assessments from the VGF and DM10 melter for the HLWS-09 and HLWS-27 feeds. Such tests could be performed on the DM100 melter system, and if needed, can be supplemented with more limited testing on the DM1200 system.

- Impacts of Increased Metal Corrosion: The test results show that increased Inconel 690 corrosion rates should be expected in HLW melts with increased sulfur contents. This could significantly affect vitrification system availability due to the increased replacement frequency for metallic components, especially bubblers. Furthermore, unlike the LAW bubblers, the HLW bubblers are not specifically designed for high-sulfur melts. Larger scale testing is required to assess the likely impacts on bubbler lifetime and failure modes. Bubbler design changes should be considered and tested, employing lessons learned from the LAW bubbler design. The potential replacement of Inconel 690 by MA758 should also be considered in view of the much superior corrosion resistance demonstrated in the present work. Finally, as suggested by the observed lower corrosion rates in melts that were at near-saturation with respect to spinel, testing should be performed to assess the extent to which the increase corrosion in high-sulfur melts can be mitigated by changes in glass composition. Such an approach has proved highly effective for K-3 refractory corrosion in LAW melts. 


\section{SECTION 7.0}

REFERENCES

[1] "Preliminary Results on Enhanced Sulfate Incorporation During Vitrification of LAW Feeds," I.L Pegg, H. Gan, I.S. Muller, D. A. McKeown, and K.S. Matlack, Interim Report, VSL-00R3630-1, Rev. 1, Vitreous State Laboratory, The Catholic University of America, Washington, DC, April 5, 2000.

[2] "Glass Formulation and Testing with RPP-WTP LAW Simulants," I.S. Muller, A.C. Buechele and I.L Pegg, Final Report, VSL-00R3560-2, Rev. 0, Vitreous State Laboratory, The Catholic University of America, Washington, DC, February 23, 2001.

[3] "Melter Tests with LAW Envelope B Simulants to Support Enhanced Sulfate Incorporation," K.S. Matlack, S.P. Morgan, and I.L. Pegg, Final Report, VSL-00R35011, Rev. 0, Vitreous State Laboratory, The Catholic University of America, Washington, DC, November 27, 2000.

[4] "Melter Tests with LAW Envelope A and C Simulants to Support Enhanced Sulfate Incorporation," K.S. Matlack, S.P. Morgan, and I.L. Pegg, VSL-01R3501-2, Rev. 0, Vitreous State Laboratory, The Catholic University of America, Washington, DC, January $26,2001$.

[5] "Baseline LAW Glass Formulation Testing," I.S. Muller and I.L Pegg, Final Report, VSL-03R3460-1, Rev. 0, Vitreous State Laboratory, The Catholic University of America, Washington, DC, August 5, 2003.

[6] "Proposed Approach for Development of LAW Glass Formulation Correlation," I.S. Muller, G. Diener, I. Joseph and I.L. Pegg, VSL-04L4460-1, Rev. 2, Vitreous State Laboratory, The Catholic University of America, Washington, DC, October 29, 2004.

[7] "RPP-WTP Pilot Melter Bubbler Life Extension Test Results Report," TRR-PLT-061, Rev. 0, Duratek, Inc., Columbia, MD, December 19, 2003.

[8] "Corrosion of K-3 Refractory and Metal Alloys in RPP-WTP LAW Glasses," H. Gan, X. Lu, I. Vidensky, C. Paul and I.L Pegg, Final Report, VSL-01R3540-1, Rev. 0, Vitreous State Laboratory, The Catholic University of America, Washington, DC, March 16, 2001.

[9] "Corrosion Testing of Bubbler Materials for LAW Vitrification," I. Vidensky, H. Gan, R.K. Mohr and I.L Pegg, Final Report, VSL-04R4430-1, Rev. 0, Vitreous State Laboratory, The Catholic University of America, Washington, DC, July 20, 2004. 
[10] "RPP-WTP LAW High Temperature Materials Assessment," I. Vidensky, M. Chaudhuri, H. Gan, G. Diener, L. Andre, R.K. Mohr and I.L Pegg, Final Report, VSL-04R4950-1, Rev. 0, Vitreous State Laboratory, The Catholic University of America, Washington, DC, January 14, 2005.

[11] "Sampling and Analysis of Sulfate Samples from the LAW Pilot Melter," W.K. Kot and I.L Pegg, Letter Report, VSL-04L4440-1, Rev. 0, Vitreous State Laboratory, The Catholic University of America, Washington, DC, July 6, 2004.

[12] "High-Level Waste Melter System Materials of Construction Testing," R.K. Mohr, I. Vidensky, C. Mooers, A.C. Buechele, R. A. Callow, K.S. Matlack and I.L Pegg, Final Report, VSL-04R5730-1, Rev. 0, Vitreous State Laboratory, The Catholic University of America, Washington, DC, June 5, 2006.

[13] "WTP Test Exception, 24590-HLW-TEF-RT-05-00007, J.D. Vienna, River Protection Projection Project, Waste Treatment Plan, Richland, WA, October 12, 2005.

[14] "Glass Formulation to Support Melter Runs with HLW Simulants," W. K. Kot, K. Klatt and I.L Pegg, Final Report, VSL-03R3760-2, Rev. 0, Vitreous State Laboratory, The Catholic University of America, Washington, DC, September 30, 2003.

[15] "HLW Glass Formulation to Support C-106/AY-102 Actual Waste Testing," W. K. Kot and I.L Pegg, Final Report, VSL-04R4770-1, Rev. 0, Vitreous State Laboratory, The Catholic University of America, Washington, DC, August 12, 2004.

[16] "Integrated DM1200 Melter Testing Using AZ-102 and C-106/AY-102 HLW Simulants: HLW Simulant Verification,” K.S. Matlack, W. Gong, T. Bardakci, N. D’Angelo, M. Brandys, W.K. Kot, and I.L. Pegg, Final Report, VSL-05R5800-1, Rev. 0, Vitreous State Laboratory, The Catholic University of America, Washington, DC, June 27, 2005.

[17] "Preparation and Testing ( $\mathrm{T}_{1 \%}$ and PCT) of HLW Matrix Glasses to Support WTP Property-Composition Model Development," W.K. Kot, H. Gan and I.L. Pegg, Final Report, VSL-05R5780-2, Rev. 0, V Vitreous State Laboratory, The Catholic University of America, Washington, DC, October 12, 2005.

[18] "Sulfate Solubility in RPP-WTP HLW Glasses," W.K. Kot, H. Gan, Z. Feng, and I.L. Pegg, Final Report, VSL-06R6780-1, Rev. 0, Vitreous State Laboratory, The Catholic University of America, Washington, DC, June 23, 2006.

[19] “Small Scale Melter Testing of HLW Algorithm Glasses: Matrix 2 Tests," K.S. Matlack, W.K. Kot, W. Gong and I.L. Pegg, Final Report, VSL-08R1220-1, Rev. 0, Vitreous State Laboratory, The Catholic University of America, Washington, DC, June 27, 2008. 
[20] "High Level Waste Vitrification System Improvements," K.S. Matlack, H. Gan, W. Gong, I.L. Pegg, C.C. Chapman, and I. Joseph, Final Report, VSL-07R1010-1, Rev. 0, Vitreous State Laboratory, The Catholic University of America, Washington, DC, April $16,2007$.

[21] "Test and Evaluate High Level Waste (HLW) Vitrification System Improvements," Contract Number DE-AC27-06RV14790, US Department of Energy, Office of River Protection, Richland, WA, April, 2006.

[22] "Next Generation Advanced Joule-Heated Melter Testing," K.S. Matlack, W.K. Kot, I.L. Pegg, and I. Joseph, Final Report, VSL-11R2320-1, Rev. 0, Vitreous State Laboratory, The Catholic University of America, Washington, DC, October 13, 2011.

[23] "Tests with High-Bismuth HLW Glasses," K.S. Matlack, H. Gan, W.K. Kot, M. Chaudhuri, R.K. Mohr, D.A. McKeown, T. Bardakci, W. Gong, A.C. Buechele, I.L. Pegg and I. Joseph, Final Report, VSL-10R1780-1, Rev. 0, Vitreous State Laboratory, The Catholic University of America, Washington, DC, December 13, 2010.

[24] "Development and Testing of High-Level Waste Glass Compositions," Contract Number DE-EM0002103, US Department of Energy, Office of River Protection, Richland, WA.

[25] "Management of High Sulfur HLW," K.S. Matlack, W.K. Kot, I.L. Pegg, and I. Joseph, Test Plan, VSL-12T2920-1, Rev. 0, Vitreous State Laboratory, The Catholic University of America, Washington, DC, December 3, 2012.

[26] "Enhanced Sulfate Management in HLW Glass Formulations," K.S. Matlack, W.K. Kot, H. Gan, I.L. Pegg, and I. Joseph, Final Report, VSL-12R2540-1, Rev. 0, Vitreous State Laboratory, The Catholic University of America, Washington, DC, September 21, 2012.

[27] "HLW Glass Development Testing," Contract Number DE-AC27-07RV14884, US Department of Energy, Office of River Protection, Richland, WA, 2007. Modified July $18,2011$.

[28] "Glass Formulation Development and DM10 Melter Testing with ORP LAW Glasses," K.S. Matlack, I. Joseph, W. Gong, I.S. Muller and I.L Pegg, Final Report, VSL09R1510-2, Rev. 0, Vitreous State Laboratory, The Catholic University of America, Washington, DC, June 12, 2009.

[29] "DuraMelter 100 HLW Simulant Validation Tests with C-106/AY-102 Feeds," K.S. Matlack, W. Gong, and I.L. Pegg, Final Report, VSL-05R5710-1, Rev. 0, Vitreous State Laboratory, The Catholic University of America, Washington, DC, June 2, 2005. 
[30] "Melter Throughput Enhancements for High Iron HLW," K.S. Matlack, H. Gan, M. Chaudhuri, W.K. Kot, I.L. Pegg and I. Joseph Final Report, VSL-12R2490-1, Rev. 0, Vitreous State Laboratory, The Catholic University of America, Washington, DC, May 31, 2012.

[31] "Melter Testing for Technetium Removal Using Goethite Precipitation," K.S. Matlack, W.K. Kot, I.L. Pegg, and I. Joseph, VSL-11R2300-1, Rev. 0, Vitreous State Laboratory, The Catholic University of America, Washington DC, September 22, 2011.

[32] "Integrated DM1200 Melter Testing of HLW AZ-102 Compositions Using Bubblers," K.S. Matlack, W. Gong, T. Bardakci, N. D’Angelo, W. Kot and I.L. Pegg, Final Report, VSL-03R3800-2, Rev. 0, Vitreous State Laboratory, The Catholic University of America, Washington, DC, September 24, 2003.

[33] "Melt Rate Enhancement for High Aluminum HLW Glass Formulations," K.S. Matlack, H. Gan, M. Chaudhuri, W.K. Kot, W. Gong, T. Bardakci, and I.L. Pegg, Final Report, VSL-08R1360-1, Rev. 0, Vitreous State Laboratory, The Catholic University of America, Washington, DC, December 19, 2008.

[34] "DM100 and DM1200 Melter Testing with High Waste Loading Glass Formulations for Hanford High-Aluminum HLW Streams," K.S. Matlack, H. Gan, M. Chaudhuri, W.K. Kot, W. Gong, T. Bardakci, I.L. Pegg and I. Joseph, Final Report, VSL-10R1690-1, Rev. 0, Vitreous State Laboratory, The Catholic University of America, Washington, DC, August 16, 2010.

[35] "Enhanced LAW Glass Formulation Testing," K.S. Matlack, I. Joseph, W. Gong, I.S. Muller, and I.L. Pegg, Final Report, VSL-07R1130-1, Rev. 0, Vitreous State Laboratory, The Catholic University of America, Washington, DC, 10/05/07.

[36] "River Protection Project System Plan," ORP-11242, Revision 6, U.S. Department of Energy, Office of River Protection, Richland, WA, October 2011.

[37] "Preliminary IHLW Formulation Algorithm Description," J.D. Vienna and D. Kim, 24590-HLW-RPT-RT-05-001, Rev. 0, River Protection Project - Waste Treatment Plant, Richland, WA, 2008.

[38] "HLW Enhancement Tests on the DuraMelter"M 10 with Hanford AZ-102 Tank Waste Simulants,” K.S. Matlack, W.K. Kot, H. Gan, R.K. Mohr, W. Gong, and I.L. Pegg, Final Report, VSL-06R5260-1, Rev. 0, Vitreous State Laboratory, The Catholic University of America, Washington, DC, February 28, 2006.

[39] "Quality Assurance Project Plan for ORP/ RPP-WTP Support Activities Conducted by VSL," Vitreous State Laboratory, QAPP-ORP, Rev. 3, Vitreous State Laboratory, The Catholic University of America, Washington, DC, October 22, 2012. 
[40] "Master List of Controlled VSL Manuals and Standard Operating Procedures in Use," QA-MLCP, Rev. 101, Vitreous State Laboratory, The Catholic University of America, Washington, DC, July 12, 2013.

[41] "Round Robin Testing of a Reference Glass for Low-Activity Waste Forms," W.L. Ebert and S.F. Wolf, Department of Energy report ANL-99/22, Argonne National Laboratory, Argonne, IL, 1999.

[42] "Development of Phase 1 IHLW Models for PCT Response and One-Percent Crystal Fraction Temperature $\left(\mathrm{T}_{1 \%}\right)$," W.K. Kot, H. Gan, Z. Feng, F. Perez-Cardenas, I.L. Pegg, S. K. Cooley and G. F. Piepel Final Report, VSL-05R5780-1, Rev. 0, V Vitreous State Laboratory, The Catholic University of America, Washington, DC, April 12, 2005.

[43] "Ammonium Sulfate Decomposition," G.L. Dugger, J.B. Adams, and R. Bart, U.S. Atomic Energy Commission Report, RMO-2036, International Minerals and Chemical Corporation, Chicago, IL, February 28, 1955.

[44] “AY-102/C-106 Actual Waste Sample Glass Formulation Guidance," CCN 067620, RPP-WTP Memorandum, C. Musick, to I.L. Pegg, March 23, 2004.

[45] "Multiple Ion Exchange Column runs for Cesium and Technetium Removal from AW-101 Waste Sample (U)," N.M. Hassan, K. Adu-Wusu, and C.A. Nash, WSRC-TR2003-00098, Rev. 0 (SRT-RPP-2003-00026, Rev. 0), Westinghouse Savannah River Company, Aiken, SC, July 2003.

[46] "Design, Construction, and Commissioning of the Hanford Tank Waste Treatment and Immobilization Plant," Contract Number: DE-AC27-01RV14136, U.S. Department of Energy, Office of River Protection, Richland, WA, August 31, 2000.

[47] "High-Temperature Corrosion of Engineering Alloys," G. Y. Lai, ASM International, 1990.

[48] "Glass Formulation Development and DM10 Melter Testing with ORP LAW Glasses," K.S. Matlack, I. Joseph, W. Gong, I.S. Muller and I.L Pegg, Final Report, VSL09R1510-2, Rev. 0, Vitreous State Laboratory, The Catholic University of America, Washington, DC, June 12, 2009.

[49] "Sulfur Incorporation in Waste Glass Melts of Various Compositions," W.K. Kot, H. Gan, and I.L. Pegg, Ceramic Transactions, Vol. 107, p. 441, Eds. G.T. Chandler and X. Feng, American Ceramic Society, 2000.

[50] "Waste Loading Enhancements for Hanford LAW Glasses," I.S. Muller, K.S. Matlack, H. Gan, I. Joseph and I.L. Pegg, Final Report, VSL-10R1790-1, Rev. 0, Vitreous State Laboratory, The Catholic University of America, Washington, DC, 12/01/10. 
[51] "Inconel 690 Corrosion in WTP HLW Melts Rich in Aluminum, Bismuth, Chromium or Aluminum/Sodium," Z.J. Feng, H. Gan and I.L. Pegg, Final Report, VSL-08R1370-1, Rev. 0, Vitreous State Laboratory, The Catholic University of America, Washington, DC, 9/23/08. 
Table 2.1. Compositional Summary (wt\% Oxide Basis) of the C-106/AY-102 Actual Waste, AW-101 Cesium-Eluate, Blended Waste, and the High-Iron HLW Simulant.

\begin{tabular}{|c|c|c|c|c|}
\hline Oxide & $\begin{array}{c}\text { Analyzed } \\
\text { C-106/AY-102 } \\
\text { Solid }\end{array}$ & $\begin{array}{c}\text { Analyzed } \\
\text { AW-101 } \\
\text { Cesium-Eluate }\end{array}$ & $\begin{array}{c}\text { Blended } \\
\text { C-106/AY-102 } \\
\text { Actual Waste }\end{array}$ & $\begin{array}{c}\text { High-Iron } \\
\text { HLW Simulant }\end{array}$ \\
\hline $\mathrm{Ag}_{2} \mathrm{O}$ & $0.50 \%$ & - & $0.50 \%$ & - \\
\hline $\mathrm{Al}_{2} \mathrm{O}_{3}$ & $13.17 \%$ & - & $13.16 \%$ & $13.29 \%$ \\
\hline $\mathrm{B}_{2} \mathrm{O}_{3}$ & $0.70 \%$ & $33.18 \%$ & $0.73 \%$ & $0.74 \%$ \\
\hline $\mathrm{BaO}$ & $0.20 \%$ & $1.68 \%$ & $0.20 \%$ & $0.20 \%$ \\
\hline $\mathrm{CaO}$ & $1.23 \%$ & - & $1.23 \%$ & $1.24 \%$ \\
\hline $\mathrm{CdO}$ & $0.03 \%$ & $0.38 \%$ & $0.03 \%$ & - \\
\hline $\mathrm{Ce}_{2} \mathrm{O}_{3}$ & $0.27 \%$ & $4.91 \%$ & $0.27 \%$ & $0.27 \%$ \\
\hline $\mathrm{Cr}_{2} \mathrm{O}_{3}$ & $0.60 \%$ & $0.69 \%$ & $0.60 \%$ & $0.61 \%$ \\
\hline $\mathrm{Cs}_{2} \mathrm{O}$ & - & $3.36 \%$ & $0.00 \%$ & $0.00 \%$ \\
\hline $\mathrm{CuO}$ & $0.09 \%$ & $2.57 \%$ & $0.09 \%$ & - \\
\hline $\mathrm{Fe}_{2} \mathrm{O}_{3}$ & $37.78 \%$ & $0.41 \%$ & $37.74 \%$ & $38.12 \%$ \\
\hline $\mathrm{Gd}_{2} \mathrm{O}_{3}$ & $0.02 \%$ & - & $0.02 \%$ & - \\
\hline $\mathrm{K}_{2} \mathrm{O}$ & $0.03 \%$ & - & $0.03 \%$ & - \\
\hline $\mathrm{La}_{2} \mathrm{O}_{3}$ & $0.20 \%$ & $0.85 \%$ & $0.20 \%$ & $0.22 \%$ \\
\hline $\mathrm{Li}_{2} \mathrm{O}$ & $0.11 \%$ & $7.34 \%$ & $0.12 \%$ & $0.12 \%$ \\
\hline $\mathrm{MgO}$ & $0.39 \%$ & - & $0.39 \%$ & $0.39 \%$ \\
\hline $\mathrm{MnO}$ & $7.61 \%$ & - & $7.60 \%$ & $7.68 \%$ \\
\hline $\mathrm{MoO}_{3}$ & $0.09 \%$ & - & $0.09 \%$ & - \\
\hline $\mathrm{Na}_{2} \mathrm{O}$ & $14.48 \%$ & $35.73 \%$ & $14.50 \%$ & $14.68 \%$ \\
\hline $\mathrm{NiO}$ & $1.11 \%$ & $1.36 \%$ & $1.11 \%$ & $1.12 \%$ \\
\hline $\mathrm{P}_{2} \mathrm{O}_{5}$ & $1.51 \%$ & - & $1.51 \%$ & $1.53 \%$ \\
\hline $\mathrm{PbO}$ & $1.46 \%$ & - & $1.46 \%$ & $1.47 \%$ \\
\hline $\mathrm{SO}_{3}$ & $0.51 \%$ & - & $0.51 \%$ & $0.52 \%$ \\
\hline $\mathrm{Sb}_{2} \mathrm{O}_{5}$ & $0.11 \%$ & - & $0.11 \%$ & - \\
\hline $\mathrm{SiO}_{2}$ & $14.28 \%$ & - & $14.27 \%$ & $14.41 \%$ \\
\hline $\mathrm{SnO}_{2}$ & $0.16 \%$ & $6.83 \%$ & $0.17 \%$ & $0.17 \%$ \\
\hline $\mathrm{SrO}$ & $0.46 \%$ & $0.71 \%$ & $0.46 \%$ & $0.46 \%$ \\
\hline $\mathrm{TiO}_{2}$ & $0.09 \%$ & - & $0.09 \%$ & - \\
\hline $\mathrm{U}_{3} \mathrm{O}_{8}$ & $1.40 \%$ & - & $1.40 \%$ & - \\
\hline $\mathrm{V}_{2} \mathrm{O}_{5}$ & $0.04 \%$ & - & $0.04 \%$ & - \\
\hline $\mathrm{ZnO}$ & $0.08 \%$ & - & $0.08 \%$ & $0.08 \%$ \\
\hline $\mathrm{ZrO}_{2}$ & $1.25 \%$ & - & $1.25 \%$ & $2.68 \%$ \\
\hline TOTAL & $100.0 \%$ & $100.0 \%$ & $100.0 \%$ & $100.0 \%$ \\
\hline
\end{tabular}

- Empty data field 
Table 2.2. Compositional Summary of the High-Iron HLW Simulant, Target Glass for Previous Melter Tests, and High Sulfur Glass from Melter Testing [26, 30].

\begin{tabular}{|c|c|c|c|c|}
\hline $\begin{array}{l}\text { Oxide } \\
(\mathbf{w t} \%)\end{array}$ & $\begin{array}{c}\text { High-Iron } \\
\text { HLW Simulant }\end{array}$ & $\begin{array}{l}\text { Target Glass for Previous } \\
\text { Melter Tests based on } \\
\text { HLW04-09 [26, 29] }\end{array}$ & $\begin{array}{c}\text { Target Glass for Previous } \\
\text { Melter Tests with } \\
\text { Enhanced HLW-NG-Fe2 } \\
\text { Formulation [30] }\end{array}$ & $\begin{array}{l}\text { Analyzed Glass from } \\
\text { Melter Testing (Highest } \\
\text { Sulfur Content, 10W-G- } \\
\text { 116A) [26] }\end{array}$ \\
\hline $\mathrm{Al}_{2} \mathrm{O}_{3}$ & $13.29 \%$ & $4.89 \%$ & $5.58 \%$ & $6.05 \%$ \\
\hline $\mathrm{B}_{2} \mathrm{O}_{3}$ & $0.74 \%$ & $10.27 \%$ & $13.81 \%$ & $13.77 \%$ \\
\hline $\mathrm{BaO}$ & $0.20 \%$ & $0.07 \%$ & $0.08 \%$ & $0.11 \%$ \\
\hline $\mathrm{Bi}_{2} \mathrm{O}_{3}$ & - & - & - & $0.01 \%$ \\
\hline $\mathrm{CaO}$ & $1.24 \%$ & $0.46 \%$ & $0.52 \%$ & $0.59 \%$ \\
\hline $\mathrm{CdO}$ & - & - & - & $0.02 \%$ \\
\hline $\mathrm{Ce}_{2} \mathrm{O}_{3}$ & $0.27 \%$ & $0.10 \%$ & $0.10 \%$ & $0.08 \%$ \\
\hline $\mathrm{Cr}_{2} \mathrm{O}_{3}$ & $0.61 \%$ & $0.22 \%$ & $0.26 \%$ & $0.26 \%$ \\
\hline $\mathrm{Fe}_{2} \mathrm{O}_{3}$ & $38.12 \%$ & $14.03 \%$ & $16.01 \%$ & $15.51 \%$ \\
\hline $\mathrm{K}_{2} \mathrm{O}$ & - & - & - & $0.45 \%$ \\
\hline $\mathrm{La}_{2} \mathrm{O}_{3}$ & $0.22 \%$ & $0.08 \%$ & $0.08 \%$ & $0.10 \%$ \\
\hline $\mathrm{Li}_{2} \mathrm{O}$ & $0.12 \%$ & $2.64 \%$ & $1.55 \%$ & $1.55 \%$ \\
\hline $\mathrm{MgO}$ & $0.39 \%$ & $0.14 \%$ & $0.16 \%$ & $0.33 \%$ \\
\hline $\mathrm{MnO}$ & $7.68 \%$ & $2.82 \%$ & $3.23 \%$ & $2.61 \%$ \\
\hline $\mathrm{Na}_{2} \mathrm{O}$ & $14.68 \%$ & $12.55 \%$ & $14.17 \%$ & $13.24 \%$ \\
\hline $\mathrm{NiO}$ & $1.12 \%$ & $0.41 \%$ & $0.47 \%$ & $0.48 \%$ \\
\hline $\mathrm{P}_{2} \mathrm{O}_{5}$ & $1.53 \%$ & $0.56 \%$ & $0.64 \%$ & $0.63 \%$ \\
\hline $\mathrm{PbO}$ & $1.47 \%$ & $0.54 \%$ & $0.62 \%$ & $0.51 \%$ \\
\hline $\mathrm{SO}_{3}$ & $0.52 \%$ & $0.19 \%$ & $0.22 \%$ & $0.36 \%$ \\
\hline $\mathrm{SiO}_{2}$ & $14.41 \%$ & $47.75 \%$ & $41.05 \%$ & $41.92 \%$ \\
\hline $\mathrm{SnO}_{2}$ & $0.17 \%$ & $0.06 \%$ & $0.07 \%$ & $0.09 \%$ \\
\hline $\mathrm{SrO}$ & $0.46 \%$ & $0.17 \%$ & $0.19 \%$ & $0.17 \%$ \\
\hline $\mathrm{TiO}_{2}$ & - & - & - & $0.09 \%$ \\
\hline $\mathrm{ZnO}$ & $0.08 \%$ & $1.03 \%$ & $0.03 \%$ & $0.08 \%$ \\
\hline $\mathrm{ZrO}_{2}$ & $2.68 \%$ & $0.98 \%$ & $1.13 \%$ & $1.00 \%$ \\
\hline TOTAL & $100.0 \%$ & $100.0 \%$ & $100.0 \%$ & $100.0 \%$ \\
\hline Volatiles (g/100 g oxide) & - & - & - & - \\
\hline Carbonate & 4.650 & - & - & - \\
\hline Nitrite & 0.012 & - & - & - \\
\hline Nitrate & 0.784 & - & - & - \\
\hline TOC & 0.026 & - & - & - \\
\hline
\end{tabular}

- Empty data field 
Table 2.3. Composition (Oxide wt\%) of HLW High Sulfur Simulant.

\begin{tabular}{|c|c|c|}
\hline Oxide & $\begin{array}{l}\text { HLW Composition from } \\
\text { HTWOS Model Run } \\
\text { (Batch 4028) }\end{array}$ & $\begin{array}{c}\text { Normalized HLW } \\
\text { Simulant Composition }\end{array}$ \\
\hline $\mathrm{Al}_{2} \mathrm{O}_{3}$ & $10.46 \%$ & $10.80 \%$ \\
\hline $\mathrm{B}_{2} \mathrm{O}_{3}$ & $0.14 \%$ & $0.14 \%$ \\
\hline $\mathrm{Bi}_{2} \mathrm{O}_{3}$ & $6.76 \%$ & $6.98 \%$ \\
\hline $\mathrm{CaO}$ & $1.57 \%$ & $1.62 \%$ \\
\hline $\mathrm{Cr}_{2} \mathrm{O}_{3}$ & $1.10 \%$ & $1.14 \%$ \\
\hline $\mathrm{F}$ & $2.23 \%$ & $2.30 \%$ \\
\hline $\mathrm{Fe}_{2} \mathrm{O}_{3}$ & $6.34 \%$ & $6.55 \%$ \\
\hline $\mathrm{K}_{2} \mathrm{O}$ & $2.34 \%$ & $2.41 \%$ \\
\hline $\mathrm{La}_{2} \mathrm{O}_{3}$ & $1.91 \%$ & $1.98 \%$ \\
\hline $\mathrm{MgO}$ & $0.71 \%$ & $0.73 \%$ \\
\hline $\mathrm{MnO}$ & $3.72 \%$ & $3.84 \%$ \\
\hline $\mathrm{Na}_{2} \mathrm{O}$ & $34.98 \%$ & $36.12 \%$ \\
\hline $\mathrm{NiO}$ & $4.57 \%$ & $4.71 \%$ \\
\hline $\mathrm{P}_{2} \mathrm{O}_{5}$ & $10.64 \%$ & $10.99 \%$ \\
\hline $\mathrm{PbO}$ & $0.32 \%$ & $0.33 \%$ \\
\hline $\mathrm{SO}_{3}$ & $4.15 \%$ & $4.29 \%$ \\
\hline $\mathrm{SiO}_{2}$ & $4.45 \%$ & $4.60 \%$ \\
\hline $\mathrm{TiO}_{2}$ & $0.14 \%$ & $0.14 \%$ \\
\hline $\mathrm{ZrO}_{2}$ & $0.31 \%$ & $0.32 \%$ \\
\hline TOTAL & $96.83 \%$ & $100.0 \%$ \\
\hline
\end{tabular}


Table 2.4. Composition of HLW Simulant to Produce $100 \mathrm{~kg}$ of Waste Oxide (21.50 wt \% total solids).

\begin{tabular}{|c|c|}
\hline Starting Materials & Target Weight (kg)" \\
\hline $\mathrm{Al}(\mathrm{OH})_{3}$ & 17.041 \\
\hline $\mathrm{H}_{3} \mathrm{BO}_{3}$ & 0.260 \\
\hline $\mathrm{Bi}_{2} \mathrm{O}_{3}$ & 7.053 \\
\hline $\mathrm{CaO}$ & 1.650 \\
\hline $\mathrm{Cr}_{2} \mathrm{O}_{3}$ & 1.160 \\
\hline $\mathrm{NaF}$ & 5.112 \\
\hline $\mathrm{Fe}(\mathrm{OH})_{3}(13 \%$ slurry $)$ & 67.379 \\
\hline $\mathrm{K}_{2} \mathrm{CO}_{3}$ & 3.596 \\
\hline $\mathrm{La}_{2} \mathrm{O}_{3}$ & 1.997 \\
\hline $\mathrm{MgO}$ & 0.754 \\
\hline $\mathrm{MnO}$ & 3.876 \\
\hline $\mathrm{NaOH}$ & 14.686 \\
\hline $\mathrm{Ni}(\mathrm{OH})_{2}$ & 6.063 \\
\hline $\mathrm{Na}_{3} \mathrm{PO}_{4}$ & 25.897 \\
\hline $\mathrm{PbO}$ & 0.334 \\
\hline $\mathrm{Na}_{2} \mathrm{SO}_{4}$ & 7.692 \\
\hline $\mathrm{SiO}_{2}$ & 4.646 \\
\hline $\mathrm{TiO}_{2}$ & 0.146 \\
\hline $\mathrm{Zr}(\mathrm{OH})_{4} \cdot x \mathrm{H}_{2} \mathrm{O}(50 \%)$ & 0.836 \\
\hline $\mathrm{Na}_{2} \mathrm{CO}_{3}$ & 5.526 \\
\hline $\mathrm{NaNO}_{2}$ & 0.019 \\
\hline $\mathrm{NaNO}_{3}$ & 1.080 \\
\hline $\mathrm{H}_{2} \mathrm{C}_{2} \mathrm{O}_{4} \cdot 2 \mathrm{H}_{2} \mathrm{O}$ & 0.138 \\
\hline Water & 371.200 \\
\hline TOTAL & 548.14 \\
\hline
\end{tabular}

${ }^{*}$ Target weights adjusted for assay information of starting materials 
Table 2.5. Nominal Target HLWS-09 Composition and XRF Analyzed Composition for Glass Discharged (wt\%).

\begin{tabular}{|c|c|c|}
\hline Oxide & $\begin{array}{c}\text { Nominal Target } \\
\text { Composition }\end{array}$ & $\begin{array}{c}\text { Analyzed Glass from } \\
\text { Melter Testing* } \\
\text { (Highest Sulfur Content, } \\
\text { 10Y-G-63A) [26] }\end{array}$ \\
\hline $\mathrm{Al}_{2} \mathrm{O}_{3}$ & 8.03 & 7.50 \\
\hline $\mathrm{B}_{2} \mathrm{O}_{3}{ }^{*}$ & 8.54 & 8.47 \\
\hline $\mathrm{Bi}_{2} \mathrm{O}_{3}$ & 1.95 & 2.10 \\
\hline $\mathrm{CaO}$ & 8.45 & 8.45 \\
\hline $\mathrm{Cl}$ & $\S$ & 0.01 \\
\hline $\mathrm{Cr}_{2} \mathrm{O}_{3}$ & 0.32 & 0.44 \\
\hline $\mathrm{F}$ & 0.64 & 0.44 \\
\hline $\mathrm{Fe}_{2} \mathrm{O}_{3}$ & 1.83 & 2.06 \\
\hline $\mathrm{K}_{2} \mathrm{O}$ & 0.68 & 0.62 \\
\hline $\mathrm{La}_{2} \mathrm{O}_{3}$ & 0.55 & 0.71 \\
\hline $\mathrm{Li}_{2} \mathrm{O}^{*}$ & 5.00 & 4.96 \\
\hline $\mathrm{MgO}_{\mathrm{MnO}}$ & 0.20 & 0.23 \\
\hline $\mathrm{Na}_{2} \mathrm{O}$ & 1.07 & 0.81 \\
\hline $\mathrm{NiO}_{2}$ & 10.11 & 9.92 \\
\hline $\mathrm{P}_{2} \mathrm{O}_{5}$ & 1.32 & 1.51 \\
\hline $\mathrm{PbO}_{\mathrm{SbO}}$ & 3.08 & 3.17 \\
\hline $\mathrm{SiO}_{2}$ & 0.09 & 0.10 \\
\hline $\mathrm{SO}_{3}$ & 41.29 & 41.50 \\
\hline $\mathrm{SrO}_{\mathrm{TiO}}$ & $\S$ & 1.64 \\
\hline $\mathrm{V}_{2} \mathrm{O}_{3}$ & 20 & 0.01 \\
\hline $\mathrm{ZnO}_{\mathrm{ZrO}}$ & $\S .04$ & 0.17 \\
\hline $\mathrm{Sum}_{2}$ & 100.00 & 1.94 \\
\hline
\end{tabular}

* Values calculated from $\mathrm{B}_{2} \mathrm{O}_{3}$ and $\mathrm{Li}_{2} \mathrm{O}$ analysis by DCP-AES on the first discharged glass and target concentrations using a simple well stirred tank model.

$\S$ - Not a target constituent 
Table 2.6. Composition (Oxide wt\%) of HLW Simulant.

\begin{tabular}{|c|c|c|}
\hline Oxide & $\begin{array}{l}\text { HLW Composition from } \\
\text { HTWOS Model Run } \\
\text { (Batch 1925) }\end{array}$ & $\begin{array}{c}\text { Normalized HLW } \\
\text { Simulant Composition }\end{array}$ \\
\hline $\mathrm{Al}_{2} \mathrm{O}_{3}$ & $14.36 \%$ & $15.75 \%$ \\
\hline $\mathrm{B}_{2} \mathrm{O}_{3}$ & $0.35 \%$ & $0.39 \%$ \\
\hline $\mathrm{Bi}_{2} \mathrm{O}_{3}$ & $2.21 \%$ & $2.43 \%$ \\
\hline $\mathrm{CaO}$ & $10.24 \%$ & $11.24 \%$ \\
\hline $\mathrm{Cr}_{2} \mathrm{O}_{3}$ & $1.65 \%$ & $1.81 \%$ \\
\hline $\mathrm{F}$ & $1.27 \%$ & $1.39 \%$ \\
\hline $\mathrm{Fe}_{2} \mathrm{O}_{3}$ & $9.48 \%$ & $10.40 \%$ \\
\hline $\mathrm{K}_{2} \mathrm{O}$ & $0.49 \%$ & $0.54 \%$ \\
\hline $\mathrm{MgO}$ & $0.23 \%$ & $0.25 \%$ \\
\hline $\mathrm{MnO}$ & $7.93 \%$ & $8.70 \%$ \\
\hline $\mathrm{Na}_{2} \mathrm{O}$ & $21.82 \%$ & $23.94 \%$ \\
\hline $\mathrm{NiO}$ & $1.52 \%$ & $1.67 \%$ \\
\hline $\mathrm{P}_{2} \mathrm{O}_{5}$ & $2.73 \%$ & $3.00 \%$ \\
\hline $\mathrm{PbO}$ & $0.33 \%$ & $0.36 \%$ \\
\hline $\mathrm{SO}_{3}$ & $1.67 \%$ & $1.83 \%$ \\
\hline $\mathrm{SiO}_{2}$ & $12.95 \%$ & $14.20 \%$ \\
\hline $\mathrm{SrO}$ & $1.80 \%$ & $1.98 \%$ \\
\hline $\mathrm{ZrO}_{2}$ & $0.12 \%$ & $0.14 \%$ \\
\hline TOTAL & $91.15 \%$ & $100.0 \%$ \\
\hline
\end{tabular}


Table 2.7. Composition of HLW Simulant to Produce $100 \mathrm{~kg}$ of Waste Oxide (21.50 wt \% total solids).

\begin{tabular}{|c|c|}
\hline Starting Materials & Target Weight (kg)" \\
\hline $\mathrm{Al}(\mathrm{OH})_{3}$ & 15.913 \\
\hline $\mathrm{H}_{3} \mathrm{BO}_{3}$ & 0.691 \\
\hline $\mathrm{Bi}_{2} \mathrm{O}_{3}$ & 2.451 \\
\hline $\mathrm{CaO}$ & 11.465 \\
\hline $\mathrm{Cr}_{2} \mathrm{O}_{3}$ & 1.846 \\
\hline $\mathrm{NaF}$ & 3.090 \\
\hline $\mathrm{Fe}(\mathrm{OH})_{3}(13 \%$ slurry $)$ & 107.018 \\
\hline $\mathrm{K}_{2} \mathrm{CO}_{3}$ & 0.808 \\
\hline $\mathrm{MgO}$ & 0.256 \\
\hline $\mathrm{MnO}$ & 8.784 \\
\hline $\mathrm{NaOH}$ & 15.270 \\
\hline $\mathrm{Ni}(\mathrm{OH})_{2}$ & 2.143 \\
\hline $\mathrm{Na}_{3} \mathrm{PO}_{4}$ & 7.069 \\
\hline $\mathrm{PbO}$ & 0.368 \\
\hline $\mathrm{Na}_{2} \mathrm{SO}_{4}$ & 3.286 \\
\hline $\mathrm{SiO}_{2}$ & 14.348 \\
\hline $\mathrm{SrCO}_{3}$ & 2.886 \\
\hline $\mathrm{Zr}(\mathrm{OH})_{4} \cdot x \mathrm{H}_{2} \mathrm{O}(50 \%)$ & 0.352 \\
\hline $\mathrm{Na}_{2} \mathrm{CO}_{3}$ & 7.643 \\
\hline $\mathrm{NaNO}_{2}$ & 0.019 \\
\hline $\mathrm{NaNO}_{3}$ & 1.080 \\
\hline $\mathrm{H}_{2} \mathrm{C}_{2} \mathrm{O}_{4} \cdot 2 \mathrm{H}_{2} \mathrm{O}$ & 0.138 \\
\hline Water & 321.454 \\
\hline TOTAL & 528.376 \\
\hline
\end{tabular}

${ }^{*}$ Target weights adjusted for assay information of starting materials 
ORP-56310 Rev. 0

The Catholic University of America

Vitreous State Laboratory
Management of High Sulfur HLW

Final Report, VSL-13R2920-1, Rev. 0

Table 2.8. Waste Loadings, Glass-Forming additives, and Target Compositions of High Sulfur HLW Glasses.

\begin{tabular}{|c|c|c|c|c|c|}
\hline & HLWS-21 & HLWS-22 & HLWS-23 & HLWS-24 & HLWS-25 \\
\hline Waste Loading & $50.00 \%$ & $43.00 \%$ & $50.00 \%$ & $52.00 \%$ & $52.00 \%$ \\
\hline $\mathbf{B}_{2} \mathbf{O}_{3}$ & $8.50 \%$ & $8.50 \%$ & $8.50 \%$ & $8.50 \%$ & $7.50 \%$ \\
\hline $\mathrm{CaO}$ & $0.00 \%$ & $2.50 \%$ & $0.00 \%$ & $0.00 \%$ & $2.50 \%$ \\
\hline $\mathrm{Li}_{2} \mathbf{O}$ & $3.50 \%$ & $4.00 \%$ & $4.00 \%$ & $3.00 \%$ & $2.50 \%$ \\
\hline $\mathrm{SiO}_{2}$ & $35.50 \%$ & $37.00 \%$ & $35.50 \%$ & $34.50 \%$ & $33.50 \%$ \\
\hline $\mathrm{V}_{2} \mathrm{O}_{5}$ & $0.00 \%$ & $2.00 \%$ & $2.00 \%$ & $2.00 \%$ & $2.00 \%$ \\
\hline $\mathrm{ZrO}_{2}$ & $2.50 \%$ & $3.00 \%$ & $0.00 \%$ & $0.00 \%$ & $0.00 \%$ \\
\hline $\begin{array}{c}\text { Glass ID } \\
\text { Composition }\end{array}$ & HLWS-21 & HLWS-22 & HLWS-23 & HLWS-24 & HLWS-25 \\
\hline $\mathrm{Al}_{2} \mathrm{O}_{3}$ & $7.877 \%$ & $6.774 \%$ & $7.877 \%$ & $8.192 \%$ & $8.192 \%$ \\
\hline $\mathbf{B}_{2} \mathbf{O}_{3}$ & $8.693 \%$ & $8.666 \%$ & $8.693 \%$ & $8.700 \%$ & $7.700 \%$ \\
\hline $\mathrm{Bi}_{2} \mathbf{O}_{3}$ & $1.213 \%$ & $1.043 \%$ & $1.213 \%$ & $1.262 \%$ & $1.262 \%$ \\
\hline $\mathrm{CaO}$ & $5.618 \%$ & $7.331 \%$ & $5.618 \%$ & $5.843 \%$ & $8.343 \%$ \\
\hline $\mathrm{Cr}_{2} \mathrm{O}_{3}$ & $0.904 \%$ & $0.778 \%$ & $0.904 \%$ & $0.941 \%$ & $0.941 \%$ \\
\hline $\mathbf{F}$ & $0.695 \%$ & $0.598 \%$ & $0.695 \%$ & $0.723 \%$ & $0.723 \%$ \\
\hline $\mathrm{Fe}_{2} \mathrm{O}_{3}$ & $5.198 \%$ & $4.470 \%$ & $5.198 \%$ & $5.406 \%$ & $5.406 \%$ \\
\hline $\mathbf{K}_{2} \mathrm{O}$ & $0.271 \%$ & $0.233 \%$ & $0.271 \%$ & $0.282 \%$ & $0.282 \%$ \\
\hline $\mathbf{L i}_{2} \mathbf{O}$ & $3.500 \%$ & $4.000 \%$ & $4.000 \%$ & $3.000 \%$ & $2.500 \%$ \\
\hline MgO & $0.124 \%$ & $0.107 \%$ & $0.124 \%$ & $0.129 \%$ & $0.129 \%$ \\
\hline MnO & $4.348 \%$ & $3.739 \%$ & $4.348 \%$ & $4.522 \%$ & $4.522 \%$ \\
\hline $\mathrm{Na}_{2} \mathrm{O}$ & $11.970 \%$ & $10.294 \%$ & $11.970 \%$ & $12.448 \%$ & $12.448 \%$ \\
\hline NiO & $0.833 \%$ & $0.717 \%$ & $0.833 \%$ & $0.867 \%$ & $0.867 \%$ \\
\hline $\mathbf{P}_{2} \mathbf{O}_{5}$ & $1.500 \%$ & $1.290 \%$ & $1.500 \%$ & $1.560 \%$ & $1.560 \%$ \\
\hline PbO & $0.182 \%$ & $0.157 \%$ & $0.182 \%$ & $0.190 \%$ & $0.190 \%$ \\
\hline $\mathrm{SO}_{3}$ & $0.916 \%$ & $0.788 \%$ & $0.916 \%$ & $0.953 \%$ & $0.953 \%$ \\
\hline $\mathrm{SiO}_{2}$ & $42.602 \%$ & $43.108 \%$ & $42.602 \%$ & $41.886 \%$ & $40.886 \%$ \\
\hline SrO & $0.988 \%$ & $0.849 \%$ & $0.988 \%$ & $1.027 \%$ & $1.027 \%$ \\
\hline $\mathrm{V}_{2} \mathrm{O}_{5}$ & $-^{(1)}$ & $2.000 \%$ & $2.000 \%$ & $2.000 \%$ & $2.000 \%$ \\
\hline $\mathrm{ZrO}_{2}$ & $2.568 \%$ & $3.059 \%$ & $0.068 \%$ & $0.071 \%$ & $0.071 \%$ \\
\hline TOTAL & $100.00 \%$ & $100.00 \%$ & $100.00 \%$ & $100.00 \%$ & $100.00 \%$ \\
\hline
\end{tabular}

(1) — Empty data field (components not present in glass). 
Table 2.8. Waste Loadings, Glass-Forming additives, and Target Compositions of High Sulfur HLW Glasses (continued).

\begin{tabular}{|c|c|c|c|c|}
\hline & HLWS-26 & HLWS-27 & HLWS-28 & HLWS-29 \\
\hline Waste Loading & $52.00 \%$ & $52.00 \%$ & $54.00 \%$ & $54.00 \%$ \\
\hline $\mathrm{B}_{2} \mathrm{O}_{3}$ & $7.80 \%$ & $9.50 \%$ & $6.00 \%$ & $6.00 \%$ \\
\hline $\mathrm{CaO}$ & $2.60 \%$ & $2.50 \%$ & $0.00 \%$ & $0.00 \%$ \\
\hline $\mathbf{L i}_{2} \mathbf{O}$ & $2.60 \%$ & $2.50 \%$ & $3.00 \%$ & $3.00 \%$ \\
\hline $\mathrm{SiO}_{2}$ & $35.00 \%$ & $33.50 \%$ & $35.00 \%$ & $33.00 \%$ \\
\hline $\mathbf{V}_{2} \mathbf{O}_{5}$ & $0.00 \%$ & $0.00 \%$ & $0.00 \%$ & $2.00 \%$ \\
\hline $\mathrm{ZrO}_{2}$ & $0.00 \%$ & $0.00 \%$ & $2.00 \%$ & $2.00 \%$ \\
\hline $\begin{array}{l}\text { Glass ID } \\
\text { Composition }\end{array}$ & HLWS-26 & HLWS-27 & HLWS-28 & HLWS-29 \\
\hline \begin{tabular}{|c|}
$\mathrm{Al}_{2} \mathbf{O}_{3}$ \\
\end{tabular} & $8.192 \%$ & $8.192 \%$ & $8.507 \%$ & $8.507 \%$ \\
\hline $\mathrm{B}_{2} \mathbf{O}_{3}$ & $8.000 \%$ & $9.700 \%$ & $6.208 \%$ & $6.208 \%$ \\
\hline $\mathbf{B i}_{2} \mathbf{O}_{3}$ & $1.262 \%$ & $1.262 \%$ & $1.310 \%$ & $1.310 \%$ \\
\hline $\mathrm{CaO}$ & $8.443 \%$ & $8.343 \%$ & $6.067 \%$ & $6.067 \%$ \\
\hline $\mathrm{Cr}_{2} \mathrm{O}_{3}$ & $0.941 \%$ & $0.941 \%$ & $0.977 \%$ & $0.977 \%$ \\
\hline $\mathbf{F}$ & $0.723 \%$ & $0.723 \%$ & $0.751 \%$ & $0.751 \%$ \\
\hline $\mathrm{Fe}_{2} \mathrm{O}_{3}$ & $5.406 \%$ & $5.406 \%$ & $5.614 \%$ & $5.614 \%$ \\
\hline $\mathrm{K}_{2} \mathrm{O}$ & $0.282 \%$ & $0.282 \%$ & $0.293 \%$ & $0.293 \%$ \\
\hline $\mathbf{L i}_{2} \mathbf{O}$ & $2.600 \%$ & $2.500 \%$ & $3.000 \%$ & $3.000 \%$ \\
\hline MgO & $0.129 \%$ & $0.129 \%$ & $0.134 \%$ & $0.134 \%$ \\
\hline MnO & $4.522 \%$ & $4.522 \%$ & $4.696 \%$ & $4.696 \%$ \\
\hline $\mathrm{Na}_{2} \mathrm{O}$ & $12.448 \%$ & $12.448 \%$ & $12.927 \%$ & $12.927 \%$ \\
\hline $\mathrm{NiO}$ & $0.867 \%$ & $0.867 \%$ & $0.900 \%$ & $0.900 \%$ \\
\hline $\mathbf{P}_{2} \mathbf{O}_{5}$ & $1.560 \%$ & $1.560 \%$ & $1.620 \%$ & $1.620 \%$ \\
\hline PbO & $0.190 \%$ & $0.190 \%$ & $0.197 \%$ & $0.197 \%$ \\
\hline $\mathrm{SO}_{3}$ & $0.953 \%$ & $0.953 \%$ & $0.989 \%$ & $0.989 \%$ \\
\hline $\mathrm{SiO}_{2}$ & $42.386 \%$ & $40.886 \%$ & $42.670 \%$ & $40.670 \%$ \\
\hline $\mathrm{SrO}$ & $1.027 \%$ & $1.027 \%$ & $1.067 \%$ & $1.067 \%$ \\
\hline $\mathbf{V}_{2} \mathbf{O}_{5}$ & - $^{(1)}$ & - & - & $2.000 \%$ \\
\hline $\mathrm{ZrO}_{2}$ & $0.071 \%$ & $0.071 \%$ & $2.074 \%$ & $2.074 \%$ \\
\hline TOTAL & $100.00 \%$ & $100.00 \%$ & $100.00 \%$ & $100.00 \%$ \\
\hline
\end{tabular}

(1) — Empty data field (components not present in glass). 
Table 2.8. Waste Loadings, Glass-Forming additives, and Target Compositions of High Sulfur HLW Glasses (continued).

\begin{tabular}{|c|c|c|c|c|}
\hline & HLWS-30 & HLWS-31 & HLWS-32 & HLWS-33 \\
\hline Waste Loading & $52.00 \%$ & $52.00 \%$ & $54.00 \%$ & $52.00 \%$ \\
\hline $\mathrm{B}_{2} \mathrm{O}_{3}$ & $7.50 \%$ & $5.00 \%$ & $5.00 \%$ & $8.00 \%$ \\
\hline $\mathrm{CaO}$ & $0.00 \%$ & $0.00 \%$ & $0.00 \%$ & $1.00 \%$ \\
\hline $\mathbf{L i}_{2} \mathbf{O}$ & $3.00 \%$ & $3.50 \%$ & $3.00 \%$ & $2.50 \%$ \\
\hline $\mathrm{SiO}_{2}$ & $35.50 \%$ & $37.00 \%$ & $36.00 \%$ & $34.50 \%$ \\
\hline $\mathrm{V}_{2} \mathrm{O}_{5}$ & $0.00 \%$ & $0.00 \%$ & $0.00 \%$ & $0.00 \%$ \\
\hline $\mathrm{ZrO}_{2}$ & $2.00 \%$ & $2.50 \%$ & $2.00 \%$ & $2.00 \%$ \\
\hline OComposition & HLWS-30 & HLWS-31 & HLWS-32 & HLWS-33 \\
\hline \begin{tabular}{|c|}
$\mathbf{A l}_{2} \mathbf{O}_{3}$ \\
\end{tabular} & $8.192 \%$ & $8.192 \%$ & $8.507 \%$ & $8.192 \%$ \\
\hline $\mathbf{B}_{2} \mathbf{O}_{3}$ & $7.700 \%$ & $5.200 \%$ & $5.208 \%$ & $8.200 \%$ \\
\hline $\mathbf{B i}_{2} \mathbf{O}_{3}$ & $1.262 \%$ & $1.262 \%$ & $1.310 \%$ & $1.262 \%$ \\
\hline $\mathrm{CaO}$ & $5.843 \%$ & $5.843 \%$ & $6.067 \%$ & $6.843 \%$ \\
\hline $\mathrm{Cr}_{2} \mathrm{O}_{3}$ & $0.941 \%$ & $0.941 \%$ & $0.977 \%$ & $0.941 \%$ \\
\hline $\mathbf{F}$ & $0.723 \%$ & $0.723 \%$ & $0.751 \%$ & $0.723 \%$ \\
\hline $\mathrm{Fe}_{2} \mathrm{O}_{3}$ & $5.406 \%$ & $5.406 \%$ & $5.614 \%$ & $5.406 \%$ \\
\hline $\mathrm{K}_{2} \mathrm{O}$ & $0.282 \%$ & $0.282 \%$ & $0.293 \%$ & $0.282 \%$ \\
\hline $\mathbf{L i}_{2} \mathbf{O}$ & $3.000 \%$ & $3.500 \%$ & $3.000 \%$ & $2.500 \%$ \\
\hline MgO & $0.129 \%$ & $0.129 \%$ & $0.134 \%$ & $0.129 \%$ \\
\hline MnO & $4.522 \%$ & $4.522 \%$ & $4.696 \%$ & $4.522 \%$ \\
\hline $\mathrm{Na}_{2} \mathrm{O}$ & $12.448 \%$ & $12.448 \%$ & $12.927 \%$ & $12.448 \%$ \\
\hline NiO & $0.867 \%$ & $0.867 \%$ & $0.900 \%$ & $0.867 \%$ \\
\hline $\mathbf{P}_{2} \mathbf{O}_{5}$ & $1.560 \%$ & $1.560 \%$ & $1.620 \%$ & $1.560 \%$ \\
\hline PbO & $0.190 \%$ & $0.190 \%$ & $0.197 \%$ & $0.190 \%$ \\
\hline $\mathrm{SO}_{3}$ & $0.953 \%$ & $0.953 \%$ & $0.989 \%$ & $0.953 \%$ \\
\hline $\mathrm{SiO}_{2}$ & $42.886 \%$ & $44.386 \%$ & $43.670 \%$ & $41.886 \%$ \\
\hline $\mathrm{SrO}$ & $1.027 \%$ & $1.027 \%$ & $1.067 \%$ & $1.027 \%$ \\
\hline $\mathrm{V}_{2} \mathrm{O}_{5}$ & $-^{(1)}$ & - & - & - \\
\hline $\mathrm{ZrO}_{2}$ & $2.071 \%$ & $2.571 \%$ & $2.074 \%$ & $2.071 \%$ \\
\hline TOTAL & $100.00 \%$ & $100.00 \%$ & $100.00 \%$ & $100.00 \%$ \\
\hline
\end{tabular}

(1) — Empty data field (components not present in glass). 
Table 2.9. Compositions of HLWS Glasses (wt\%) Analyzed by XRF.

\begin{tabular}{|c|c|c|c|c|c|}
\hline Oxide & HLWS-21 & HLWS-22 & HLWS-23 & HLWS-24 & HLWS-25 \\
\hline $\mathrm{Al}_{2} \mathbf{O}_{3}$ & $7.36 \%$ & $6.44 \%$ & $7.41 \%$ & $7.66 \%$ & $7.73 \%$ \\
\hline $\mathbf{B}_{2} \mathbf{O}_{3}{ }^{(1)}$ & $8.69 \%$ & $8.67 \%$ & $8.69 \%$ & $8.70 \%$ & $7.70 \%$ \\
\hline $\mathbf{B i}_{2} \mathbf{O}_{3}$ & $1.30 \%$ & $1.14 \%$ & $1.36 \%$ & $1.38 \%$ & $1.42 \%$ \\
\hline $\mathrm{CaO}$ & $5.77 \%$ & $7.47 \%$ & $5.84 \%$ & $6.07 \%$ & $8.73 \%$ \\
\hline $\mathrm{Cr}_{2} \mathrm{O}_{3}$ & $0.87 \%$ & $0.82 \%$ & $0.98 \%$ & $1.00 \%$ & $1.00 \%$ \\
\hline $\mathbf{F}^{(1)}$ & $0.70 \%$ & $0.60 \%$ & $0.70 \%$ & $0.72 \%$ & $0.72 \%$ \\
\hline $\mathrm{Fe}_{2} \mathrm{O}_{3}$ & $5.13 \%$ & $4.40 \%$ & $5.26 \%$ & $5.44 \%$ & $5.40 \%$ \\
\hline $\mathbf{K}_{2} \mathbf{O}$ & $0.31 \%$ & $0.28 \%$ & $0.34 \%$ & $0.33 \%$ & $0.34 \%$ \\
\hline $\mathbf{L i}_{2} \mathbf{O}^{(1)}$ & $3.50 \%$ & $4.00 \%$ & $4.00 \%$ & $3.00 \%$ & $2.50 \%$ \\
\hline MgO & $0.10 \%$ & $0.11 \%$ & $0.12 \%$ & $0.11 \%$ & $0.12 \%$ \\
\hline MnO & $4.28 \%$ & $3.60 \%$ & $4.23 \%$ & $4.45 \%$ & $4.44 \%$ \\
\hline $\mathrm{Na}_{2} \mathrm{O}$ & $12.01 \%$ & $10.58 \%$ & $11.94 \%$ & $12.25 \%$ & $12.08 \%$ \\
\hline $\mathrm{NiO}$ & $0.91 \%$ & $0.71 \%$ & $0.89 \%$ & $0.95 \%$ & $0.99 \%$ \\
\hline $\mathbf{P}_{2} \mathbf{O}_{5}$ & $1.80 \%$ & $1.50 \%$ & $1.72 \%$ & $1.84 \%$ & $1.83 \%$ \\
\hline PbO & $0.20 \%$ & $0.16 \%$ & $0.18 \%$ & $0.20 \%$ & $0.21 \%$ \\
\hline $\mathrm{SO}_{3}$ & $0.84 \%$ & $0.72 \%$ & $0.89 \%$ & $0.88 \%$ & $0.90 \%$ \\
\hline $\mathrm{SiO}_{2}$ & $42.59 \%$ & $43.07 \%$ & $42.26 \%$ & $41.71 \%$ & $40.56 \%$ \\
\hline SrO & $0.95 \%$ & $0.79 \%$ & $0.97 \%$ & $1.00 \%$ & $1.01 \%$ \\
\hline $\mathbf{V}_{2} \mathbf{O}_{5}$ & $-^{(2)}$ & $1.88 \%$ & $1.97 \%$ & $1.97 \%$ & $2.01 \%$ \\
\hline $\mathrm{ZrO}_{2}$ & $2.58 \%$ & $2.98 \%$ & $0.24 \%$ & $0.26 \%$ & $0.27 \%$ \\
\hline TOTAL & $99.9 \%$ & $99.9 \%$ & $100.0 \%$ & $99.9 \%$ & $100.0 \%$ \\
\hline
\end{tabular}

(1) $\mathrm{B}_{2} \mathrm{O}_{3}, \mathrm{~F}$, and $\mathrm{Li}_{2} \mathrm{O}$ are not analyzed by XRF; target values (boldface) are used.

(2) _ Empty data field (components not present in glass). 
Table 2.9. Compositions of HLWS Glasses (wt\%) Analyzed by XRF (continued).

\begin{tabular}{|c|c|c|c|c|}
\hline Oxide & HLWS-26 & HLWS-27 & HLWS-28 & HLWS-29 \\
\hline $\mathbf{A l}_{2} \mathbf{O}_{3}$ & $7.73 \%$ & $7.58 \%$ & $8.39 \%$ & $8.34 \%$ \\
\hline $\mathbf{B}_{2} \mathbf{O}_{3}^{(1)}$ & $8.00 \%$ & $9.70 \%$ & $6.21 \%$ & $6.21 \%$ \\
\hline $\mathrm{Bi}_{2} \mathbf{O}_{3}$ & $1.42 \%$ & $1.42 \%$ & $1.45 \%$ & $1.40 \%$ \\
\hline $\mathrm{CaO}$ & $8.80 \%$ & $8.77 \%$ & $6.38 \%$ & $6.19 \%$ \\
\hline $\mathrm{Cr}_{2} \mathrm{O}_{3}$ & $0.89 \%$ & $0.93 \%$ & $0.96 \%$ & $0.99 \%$ \\
\hline$F^{(1)}$ & $0.72 \%$ & $0.72 \%$ & $0.75 \%$ & $0.75 \%$ \\
\hline $\mathrm{Fe}_{2} \mathrm{O}_{3}$ & $5.40 \%$ & $5.56 \%$ & $5.42 \%$ & $5.35 \%$ \\
\hline $\mathrm{K}_{2} \mathrm{O}$ & $0.37 \%$ & $0.35 \%$ & $0.32 \%$ & $0.33 \%$ \\
\hline $\mathbf{L i}_{2} \mathbf{O}^{(1)}$ & $2.60 \%$ & $2.50 \%$ & $3.00 \%$ & $3.00 \%$ \\
\hline MgO & $0.13 \%$ & $0.12 \%$ & $0.11 \%$ & $0.13 \%$ \\
\hline MnO & $4.53 \%$ & $4.52 \%$ & $4.75 \%$ & $4.66 \%$ \\
\hline $\mathrm{Na}_{2} \mathrm{O}$ & $12.28 \%$ & $12.18 \%$ & $12.81 \%$ & $13.16 \%$ \\
\hline $\mathrm{NiO}$ & $0.94 \%$ & $1.01 \%$ & $1.00 \%$ & $0.99 \%$ \\
\hline $\mathbf{P}_{2} \mathbf{O}_{5}$ & $1.83 \%$ & $1.79 \%$ & $1.66 \%$ & $1.60 \%$ \\
\hline $\mathbf{P b O}$ & $0.21 \%$ & $0.22 \%$ & $0.19 \%$ & $0.18 \%$ \\
\hline $\mathrm{SO}_{3}$ & $0.93 \%$ & $0.86 \%$ & $0.90 \%$ & $0.94 \%$ \\
\hline $\mathrm{SiO}_{2}$ & $41.91 \%$ & $40.47 \%$ & $42.45 \%$ & $40.68 \%$ \\
\hline $\mathrm{SrO}$ & $1.02 \%$ & $1.02 \%$ & $1.04 \%$ & $1.02 \%$ \\
\hline $\mathrm{V}_{2} \mathbf{O}_{5}$ & — $^{(2)}$ & - & - & $1.94 \%$ \\
\hline $\mathrm{ZrO}_{2}$ & $0.26 \%$ & $0.26 \%$ & $2.14 \%$ & $2.08 \%$ \\
\hline TOTAL & $100.0 \%$ & $100.0 \%$ & $99.9 \%$ & $100.0 \%$ \\
\hline
\end{tabular}

(1) $\mathrm{B}_{2} \mathrm{O}_{3}, \mathrm{~F}$, and $\mathrm{Li}_{2} \mathrm{O}$ are not analyzed by XRF; target values (boldface) are used.

(2) - Empty data field (components not present in glass). 
Table 2.9. Compositions of HLWS Glasses (wt\%) Analyzed by XRF (continued).

\begin{tabular}{|c|c|c|c|c|}
\hline Oxide & HLWS-30 & HLWS-31 & HLWS-32 & HLWS-33 \\
\hline $\mathrm{Al}_{2} \mathrm{O}_{3}$ & $7.94 \%$ & $7.99 \%$ & $8.50 \%$ & $8.03 \%$ \\
\hline $\mathbf{B}_{2} \mathbf{O}_{3}{ }^{(1)}$ & $7.70 \%$ & $5.20 \%$ & $5.21 \%$ & $8.20 \%$ \\
\hline $\mathrm{Bi}_{2} \mathbf{O}_{3}$ & $1.41 \%$ & $1.37 \%$ & $1.42 \%$ & $1.38 \%$ \\
\hline $\mathrm{CaO}$ & $6.07 \%$ & $6.00 \%$ & $6.27 \%$ & $7.10 \%$ \\
\hline $\mathrm{Cr}_{2} \mathrm{O}_{3}$ & $0.91 \%$ & $0.93 \%$ & $0.99 \%$ & $0.95 \%$ \\
\hline $\mathbf{F}^{(\mathbf{1})}$ & $0.72 \%$ & $0.72 \%$ & $0.75 \%$ & $0.72 \%$ \\
\hline $\mathrm{Fe}_{2} \mathrm{O}_{3}$ & $5.30 \%$ & $5.13 \%$ & $5.40 \%$ & $5.18 \%$ \\
\hline $\mathbf{K}_{2} \mathbf{O}$ & $0.31 \%$ & $0.31 \%$ & $0.31 \%$ & $0.32 \%$ \\
\hline $\mathbf{L i}_{2} \mathbf{O}^{(\mathbf{1})}$ & $3.00 \%$ & $3.50 \%$ & $3.00 \%$ & $2.50 \%$ \\
\hline MgO & $0.12 \%$ & $0.13 \%$ & $0.11 \%$ & $0.11 \%$ \\
\hline MnO & $4.71 \%$ & $4.44 \%$ & $4.68 \%$ & $4.65 \%$ \\
\hline $\mathrm{Na}_{2} \mathrm{O}$ & $12.58 \%$ & $12.73 \%$ & $13.10 \%$ & $12.25 \%$ \\
\hline $\mathrm{NiO}$ & $0.97 \%$ & $0.94 \%$ & $0.98 \%$ & $1.00 \%$ \\
\hline $\mathbf{P}_{2} \mathbf{O}_{5}$ & $1.57 \%$ & $1.59 \%$ & $1.71 \%$ & $1.54 \%$ \\
\hline PbO & $0.18 \%$ & $0.18 \%$ & $0.17 \%$ & $0.18 \%$ \\
\hline $\mathrm{SO}_{3}$ & $0.88 \%$ & $1.17 \%$ & $0.96 \%$ & $1.13 \%$ \\
\hline $\mathrm{SiO}_{2}$ & $42.28 \%$ & $44.00 \%$ & $43.20 \%$ & $41.58 \%$ \\
\hline SrO & $1.04 \%$ & $0.98 \%$ & $1.04 \%$ & $1.00 \%$ \\
\hline $\mathrm{V}_{2} \mathrm{O}_{5}$ & $-^{(2)}$ & - & - & - \\
\hline $\mathrm{ZrO}_{2}$ & $2.21 \%$ & $2.59 \%$ & $2.13 \%$ & $2.13 \%$ \\
\hline TOTAL & $99.9 \%$ & $99.9 \%$ & $99.9 \%$ & $99.9 \%$ \\
\hline
\end{tabular}

(1) $\mathrm{B}_{2} \mathrm{O}_{3}, \mathrm{~F}$, and $\mathrm{Li}_{2} \mathrm{O}$ are not analyzed by XRF; target values (boldface) are used.

(2) - Empty data field (components not present in glass). 
Table 2.10. Characterization Data for the HLWS Series of Glasses.

\begin{tabular}{|c|c|c|c|c|c|c|}
\hline \multicolumn{3}{|c|}{ Property } & HLWS-21 & HLWS-22 & HLWS-23 & HLWS-24 \\
\hline \multirow{5}{*}{\multicolumn{2}{|c|}{ 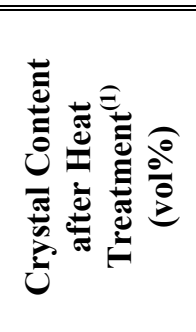 }} & $800^{\circ} \mathrm{C}$ & $\begin{array}{c}2.43(\mathrm{CaP}), \\
1.58(\mathrm{Sp})\end{array}$ & $\begin{array}{c}1.56(\mathrm{CaP}), \\
0.98(\mathrm{Sp})\end{array}$ & $\begin{array}{c}2.42(\mathrm{CaP}), \\
1.34(\mathrm{Sp})\end{array}$ & $\begin{array}{c}2.60(\mathrm{CaP}), \\
2.01(\mathrm{Sp})\end{array}$ \\
\hline & & $850^{\circ} \mathrm{C}$ & $\begin{array}{c}2.61(\mathrm{CaP}), 1.25 \\
(\mathrm{Sp})\end{array}$ & $\begin{array}{c}2.61(\mathrm{CaP}), 0.88 \\
(\mathrm{Sp})^{(1)}\end{array}$ & $\begin{array}{c}2.44(\mathrm{CaP}), 1.10 \\
(\mathrm{Sp})\end{array}$ & $\begin{array}{c}.07(\mathrm{CaP}), \\
1.24(\mathrm{Sp}) \\
\end{array}$ \\
\hline & & $900^{\circ} \mathrm{C}$ & $\begin{array}{c}1.02(\mathrm{Sp}), \\
0.56(\mathrm{CaP}) \\
\end{array}$ & $\begin{array}{c}0.68(\mathrm{Sp}) \\
0.14(\mathrm{CaP}) \\
\end{array}$ & $0.83(\mathrm{Sp})$ & $\begin{array}{c}1.14(\mathrm{CaP}), \\
1.06(\mathrm{Sp}) \\
\end{array}$ \\
\hline & & $950^{\circ} \mathrm{C}$ & $0.53(\mathrm{Sp})$ & $0.54(\mathrm{Sp})$ & $0.95(\mathrm{Sp})$ & $1.13(\mathrm{Sp})$ \\
\hline & & $1000^{\circ} \mathrm{C}$ & $0.48(\mathrm{Sp})$ & $0.13(\mathrm{Sp})$ & $0.22(\mathrm{Sp})$ & $0.22(\mathrm{Sp})$ \\
\hline \multirow{7}{*}{ 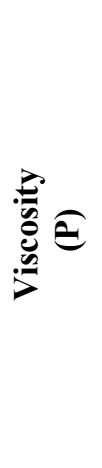 } & \multirow{4}{*}{ 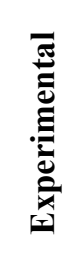 } & Temperature 1 & $265.99\left(953^{\circ} \mathrm{C}\right)$ & - $^{(2)}$ & - & - \\
\hline & & Temperature 2 & $75.63\left(1052^{\circ} \mathrm{C}\right)$ & - & - & - \\
\hline & & Temperature 3 & $28.72\left(1152^{\circ} \mathrm{C}\right)$ & - & - & - \\
\hline & & Temperature 4 & $13.43\left(1252^{\circ} \mathrm{C}\right)$ & - & - & - \\
\hline & \multirow{3}{*}{$\underbrace{0}_{i=1}$} & $1050^{\circ} \mathrm{C}$ & 77.26 & - & - & - \\
\hline & & $1150^{\circ} \mathrm{C}$ & 29.22 & - & - & - \\
\hline & & $1250^{\circ} \mathrm{C}$ & 13.62 & - & - & - \\
\hline \multirow{7}{*}{ 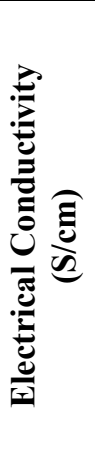 } & \multirow{4}{*}{ } & Temperature 1 & $0.144\left(965^{\circ} \mathrm{C}\right)$ & - & - & - \\
\hline & & Temperature 2 & $0.217\left(1061^{\circ} \mathrm{C}\right)$ & - & - & - \\
\hline & & Temperature 3 & $0.321\left(1158^{\circ} \mathrm{C}\right)$ & - & - & - \\
\hline & & Temperature 4 & $0.443\left(1253^{\circ} \mathrm{C}\right)$ & - & - & - \\
\hline & \multirow{3}{*}{$\underbrace{0}_{i=1}$} & $1050^{\circ} \mathrm{C}$ & 0.210 & - & - & - \\
\hline & & $1150^{\circ} \mathrm{C}$ & 0.311 & - & - & - \\
\hline & & $1250^{\circ} \mathrm{C}$ & 0.437 & - & - & - \\
\hline \multirow{3}{*}{\multicolumn{2}{|c|}{ 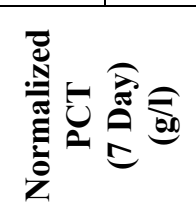 }} & $\mathrm{B}$ & $-^{(2)}$ & - & 0.486 & - \\
\hline & & $\mathrm{Li}$ & - & - & 0.603 & - \\
\hline & & $\mathrm{Na}$ & - & - & 0.634 & - \\
\hline \multirow{3}{*}{\multicolumn{2}{|c|}{ 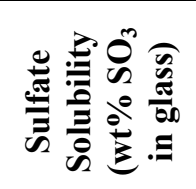 }} & Target $^{(4)}$ & $0.92 \%$ & $0.79 \%$ & $0.92 \%$ & $0.95 \%$ \\
\hline & & Over-Saturation & $1.26 \%$ & $1.50 \%$ & $1.51 \%$ & $1.30 \%$ \\
\hline & & Gas Bubbling & $1.19 \%$ & - & $1.61 \%$ & - \\
\hline
\end{tabular}

$\mathrm{Sp}=$ Spinel, $\mathrm{CaP}=$ Calcium Phosphate.

(1) Data point not used in estimate of $\mathrm{T}_{1 \%}$.

(2) - Empty data field (not analyzed).

(3) Calculated from fit of Vogel-Fulcher equation to the experimental data.

(4) Target $\mathrm{SO}_{3}$ concentration in the nominal glass composition. 
Table 2.10. Characterization Data for the HLWS Series of Glasses (continued).

\begin{tabular}{|c|c|c|c|c|c|c|}
\hline \multicolumn{3}{|c|}{ Property } & HLWS-25 & HLWS-26 & HLWS-27 & HLWS-28 \\
\hline \multirow{5}{*}{\multicolumn{2}{|c|}{ 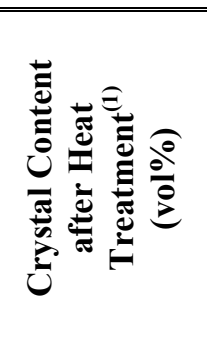 }} & $800^{\circ} \mathrm{C}$ & $\begin{array}{c}3.25(\mathrm{CaP}) \\
2.27(\mathrm{Sp})\end{array}$ & $\begin{array}{l}2.23(\mathrm{CaP}) \\
1.74(\mathrm{Sp})^{(1)}\end{array}$ & $\begin{array}{c}2.66(\mathrm{CaP}) \\
2.22(\mathrm{Sp})\end{array}$ & $\begin{array}{c}2.88(\mathrm{CaP}) \\
2.21(\mathrm{Sp})\end{array}$ \\
\hline & & $850^{\circ} \mathrm{C}$ & $\begin{array}{c}3.93(\mathrm{CaP}), \\
1.31(\mathrm{Sp})\end{array}$ & $\begin{array}{c}3.29(\mathrm{CaP}) \\
1.26(\mathrm{Sp})\end{array}$ & $\begin{array}{c}3.46(\mathrm{CaP}) \\
1.59(\mathrm{Sp})\end{array}$ & $\begin{array}{c}2.39(\mathrm{CaP}) \\
2.38(\mathrm{Sp})\end{array}$ \\
\hline & & $900^{\circ} \mathrm{C}$ & $\begin{array}{c}1.47(\mathrm{CaP}) \\
1.07(\mathrm{Sp})\end{array}$ & $\begin{array}{c}1.39(\mathrm{CaP}) \\
1.00(\mathrm{Sp})\end{array}$ & $\begin{array}{c}2.13(\mathrm{CaP}) \\
1.01(\mathrm{Sp})\end{array}$ & $\begin{array}{c}1.55(\mathrm{CaP}) \\
1.45(\mathrm{Sp})\end{array}$ \\
\hline & & $950^{\circ} \mathrm{C}$ & $\begin{array}{c}0.84(\mathrm{CaP}), \\
0.75 \mathrm{Sp}) \\
\end{array}$ & $\begin{array}{c}0.68(\mathrm{Sp}), \\
0.52(\mathrm{CaP}) \\
\end{array}$ & $\begin{array}{c}0.71(\mathrm{Sp}), \\
0.20(\mathrm{CaP}) \\
\end{array}$ & $1.17(\mathrm{Sp})$ \\
\hline & & $1000^{\circ} \mathrm{C}$ & $0.49(\mathrm{Sp})$ & $0.49(\mathrm{Sp})$ & $0.47(\mathrm{Sp})$ & $0.82(\mathrm{Sp})$ \\
\hline \multirow{7}{*}{ 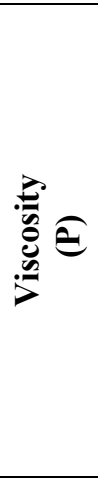 } & \multirow{4}{*}{ } & Temperature 1 & $206.01\left(951^{\circ} \mathrm{C}\right)$ & $-^{(2)}$ & $178.77\left(958^{\circ} \mathrm{C}\right)$ & - \\
\hline & & Temperature 2 & $61.01\left(1051^{\circ} \mathrm{C}\right)$ & - & $53.07\left(1056^{\circ} \mathrm{C}\right)$ & - \\
\hline & & Temperature 3 & $23.75\left(1152^{\circ} \mathrm{C}\right)$ & - & $21.09\left(1156^{\circ} \mathrm{C}\right)$ & - \\
\hline & & Temperature 4 & $11.36\left(1253^{\circ} \mathrm{C}\right)$ & - & $10.23\left(1255^{\circ} \mathrm{C}\right)$ & - \\
\hline & \multirow{3}{*}{ 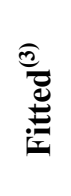 } & $1050^{\circ} \mathrm{C}$ & 61.58 & - & 56.77 & - \\
\hline & & $1150^{\circ} \mathrm{C}$ & 24.19 & - & 22.06 & - \\
\hline & & $1250^{\circ} \mathrm{C}$ & 11.57 & - & 10.59 & - \\
\hline \multirow{7}{*}{ 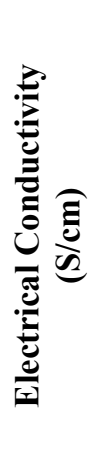 } & \multirow{4}{*}{ } & Temperature 1 & $0.136\left(963^{\circ} \mathrm{C}\right)$ & - & $0.136\left(960^{\circ} \mathrm{C}\right)$ & - \\
\hline & & Temperature 2 & $0.211\left(1058^{\circ} \mathrm{C}\right)$ & - & $0.217\left(1056^{\circ} \mathrm{C}\right)$ & - \\
\hline & & Temperature 3 & $0.312\left(1155^{\circ} \mathrm{C}\right)$ & - & $0.320\left(1154^{\circ} \mathrm{C}\right)$ & - \\
\hline & & Temperature 4 & $0.428\left(1251^{\circ} \mathrm{C}\right)$ & - & $0.452\left(1250^{\circ} \mathrm{C}\right)$ & - \\
\hline & \multirow{3}{*}{ 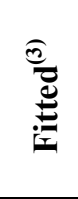 } & $1050^{\circ} \mathrm{C}$ & 0.205 & - & 0.210 & - \\
\hline & & $1150^{\circ} \mathrm{C}$ & 0.305 & - & 0.317 & - \\
\hline & & $1250^{\circ} \mathrm{C}$ & 0.428 & - & 0.451 & - \\
\hline \multirow{3}{*}{\multicolumn{2}{|c|}{ 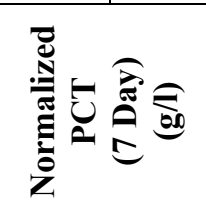 }} & $\mathrm{B}$ & 0.359 & - & 0.345 & - \\
\hline & & $\mathrm{Li}$ & 0.508 & - & 0.462 & - \\
\hline & & $\mathrm{Na}$ & 0.559 & - & 0.522 & - \\
\hline \multirow{3}{*}{\multicolumn{2}{|c|}{ 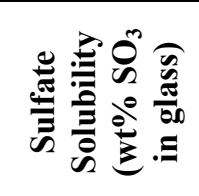 }} & Target $^{(4)}$ & $0.95 \%$ & $0.95 \%$ & $0.95 \%$ & $0.99 \%$ \\
\hline & & Over-Saturation & $1.49 \%$ & $1.39 \%$ & $1.43 \%$ & $1.04 \%$ \\
\hline & & Gas Bubbling & $1.57 \%$ & - & $1.54 \%$ & - \\
\hline
\end{tabular}

$\mathrm{Sp}=$ Spinel, $\mathrm{CaP}=$ Calcium Phosphate.

\footnotetext{
${ }^{(1)}$ Data point not used in estimate of $\mathrm{T}_{1 \%}$.

(2) - Empty data field (not analyzed).

(3) Calculated from fit of Vogel-Fulcher equation to the experimental data.

(4) Target $\mathrm{SO}_{3}$ concentration in the nominal glass composition.
} 
Table 2.10. Characterization Data for the HLWS Series of Glasses (continued).

\begin{tabular}{|c|c|c|c|c|c|c|}
\hline & & perty & HLWS-29 & HLWS-30 & HLWS-31 & HLWS-32 \\
\hline & & $800^{\circ} \mathrm{C}$ & $\begin{array}{c}.18(\mathrm{CaP}), \\
2.23(\mathrm{Sp}) \\
\end{array}$ & $\begin{array}{c}2.64(\mathrm{CaP}), \\
1.82(\mathrm{Sp}) \\
\end{array}$ & $\begin{array}{c}2.28(\mathrm{Sp}), \\
1.86(\mathrm{CaP})^{(1)} \\
\end{array}$ & $\begin{array}{c}2.38(\mathrm{CaP}), \\
2.29(\mathrm{Sp}) \\
\end{array}$ \\
\hline$\stackrel{\bar{\Xi}}{\Xi}$ & & $850^{\circ} \mathrm{C}$ & $\begin{array}{c}2.69(\mathrm{CaP}) \\
1.98(\mathrm{Sp})\end{array}$ & $\begin{array}{c}2.35(\mathrm{CaP}) \\
1.71(\mathrm{Sp})\end{array}$ & $\begin{array}{l}2.61(\mathrm{CaP}) \\
1.72(\mathrm{Sp})^{(1)}\end{array}$ & $\begin{array}{c}3.30(\mathrm{CaP}) \\
1.54(\mathrm{Sp})\end{array}$ \\
\hline$\underbrace{0}_{\pi}$ & $\frac{e^{0}}{0}$ & $900^{\circ} \mathrm{C}$ & $\begin{array}{c}1.44(\mathrm{CaP}) \\
1.42(\mathrm{Sp})\end{array}$ & $\begin{array}{c}1.52(\mathrm{CaP}) \\
0.98(\mathrm{Sp})\end{array}$ & $1.32(\mathrm{Sp})$ & $\begin{array}{c}1.72(\mathrm{CaP}) \\
1.60(\mathrm{Sp})\end{array}$ \\
\hline 茪 & & $950^{\circ} \mathrm{C}$ & $1.00(\mathrm{Sp})$ & $0.89(\mathrm{Sp})$ & $0.86(\mathrm{Sp})$ & $0.98(\mathrm{Sp})$ \\
\hline & & $1000^{\circ} \mathrm{C}$ & $0.94(\mathrm{Sp})$ & $0.54(\mathrm{Sp})$ & $0.61(\mathrm{Sp})$ & $0.60(\mathrm{Sp})$ \\
\hline & $\bar{J}$ & Temperature 1 & $282.37\left(952^{\circ} \mathrm{C}\right)$ & $352.20\left(952^{\circ} \mathrm{C}\right)$ & $471.80\left(953^{\circ} \mathrm{C}\right)$ & - $^{(2)}$ \\
\hline & $\Xi$ & Temperature 2 & $79.32\left(1051^{\circ} \mathrm{C}\right)$ & $94.98\left(1052^{\circ} \mathrm{C}\right)$ & $126.73\left(1052^{\circ} \mathrm{C}\right)$ & - \\
\hline & : & Temperature 3 & $29.99\left(1150^{\circ} \mathrm{C}\right)$ & $35.49\left(1153^{\circ} \mathrm{C}\right)$ & $44.30\left(1152^{\circ} \mathrm{C}\right)$ & - \\
\hline$\overline{0}$ & I & Temperature 4 & $13.64\left(1250^{\circ} \mathrm{C}\right)$ & $15.71\left(1254^{\circ} \mathrm{C}\right)$ & $20.17\left(1252^{\circ} \mathrm{C}\right)$ & - \\
\hline & & $1050^{\circ} \mathrm{C}$ & 80.44 & 97.36 & 128.24 & - \\
\hline & 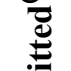 & $1150^{\circ} \mathrm{C}$ & 29.92 & 36.31 & 45.77 & - \\
\hline & I & $1250^{\circ} \mathrm{C}$ & 13.65 & 16.20 & 20.34 & - \\
\hline & $\bar{\pi}$ & Temperature 1 & $0.166\left(962^{\circ} \mathrm{C}\right)$ & $0.151\left(963^{\circ} \mathrm{C}\right)$ & $0.166\left(966^{\circ} \mathrm{C}\right)$ & - \\
\hline & 离 & Temperature 2 & $0.279\left(1059^{\circ} \mathrm{C}\right)$ & $0.252\left(1061^{\circ} \mathrm{C}\right)$ & $0.267\left(1062^{\circ} \mathrm{C}\right)$ & - \\
\hline$\stackrel{E}{E}_{0}$ & 苞 & Temperature 3 & $0.405\left(1154^{\circ} \mathrm{C}\right)$ & $0.323\left(1156^{\circ} \mathrm{C}\right)$ & $0.381\left(1156^{\circ} \mathrm{C}\right)$ & - \\
\hline Uू & 齐 & Temperature 4 & $0.546\left(1250^{\circ} \mathrm{C}\right)$ & $0.443\left(1253^{\circ} \mathrm{C}\right)$ & $0.497\left(1252^{\circ} \mathrm{C}\right)$ & - \\
\hline . & $\widehat{0}$ & $1050^{\circ} \mathrm{C}$ & 0.267 & 0.234 & 0.255 & - \\
\hline$\frac{\bar{e}}{x}$ & E्ञ & $1150^{\circ} \mathrm{C}$ & 0.400 & 0.332 & 0.372 & - \\
\hline & & $1250^{\circ} \mathrm{C}$ & 0.545 & 0.431 & 0.495 & - \\
\hline & & $\mathrm{B}$ & 0.463 & - & - & 0.359 \\
\hline 穿 苞 & & $\mathrm{Li}$ & 0.587 & - & - & 0.519 \\
\hline$\ddot{z}$ & & $\mathrm{Na}$ & 0.640 & - & - & 0.589 \\
\hline & & Target $^{(4)}$ & $0.99 \%$ & $0.95 \%$ & $0.95 \%$ & $0.99 \%$ \\
\hline 焉 & & Over-Saturation & $1.11 \%$ & $1.09 \%$ & $1.05 \%$ & $1.04 \%$ \\
\hline & & Gas Bubbling & $1.24 \%$ & $1.07 \%$ & $1.01 \%$ & - \\
\hline
\end{tabular}

$\mathrm{Sp}=$ Spinel, $\mathrm{CaP}=$ Calcium Phosphate.

\footnotetext{
(1) Data point not used in estimate of $\mathrm{T}_{1 \%}$.

(2) - Empty data field (not analyzed).

(3) Calculated from fit of Vogel-Fulcher equation to the experimental data.

(4) Target $\mathrm{SO}_{3}$ concentration in the nominal glass composition.
} 
Table 2.10. Characterization Data for the HLWS Series of Glasses (continued).

\begin{tabular}{|c|c|c|c|}
\hline \multicolumn{3}{|c|}{ Property } & HLWS-33 \\
\hline \multirow{5}{*}{\multicolumn{2}{|c|}{ 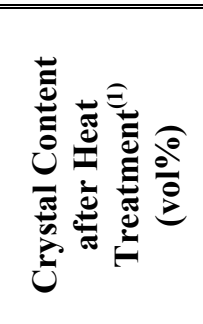 }} & $800^{\circ} \mathrm{C}$ & $\begin{array}{c}2.68(\mathrm{CaP}) \\
1.79(\mathrm{Sp}) \\
\end{array}$ \\
\hline & & $850^{\circ} \mathrm{C}$ & $\begin{array}{c}3.15(\mathrm{CaP}), \\
1.35(\mathrm{Sp})\end{array}$ \\
\hline & & $900^{\circ} \mathrm{C}$ & $\begin{array}{c}2.05(\mathrm{CaP}) \\
1.24(\mathrm{Sp}) \\
\end{array}$ \\
\hline & & $950^{\circ} \mathrm{C}$ & $\begin{array}{r}0.88(\mathrm{Sp}) \\
0.75(\mathrm{CaP}) \\
\end{array}$ \\
\hline & & $1000^{\circ} \mathrm{C}$ & $-^{(1)}$ \\
\hline \multirow{7}{*}{ 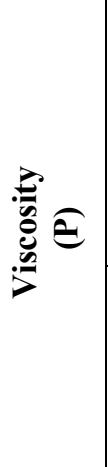 } & \multirow{4}{*}{ 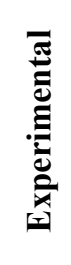 } & Temperature 1 & - \\
\hline & & Temperature 2 & - \\
\hline & & Temperature 3 & - \\
\hline & & Temperature 4 & - \\
\hline & \multirow{3}{*}{ 跑 } & $1050^{\circ} \mathrm{C}$ & - \\
\hline & & $1150^{\circ} \mathrm{C}$ & - \\
\hline & & $1250^{\circ} \mathrm{C}$ & - \\
\hline \multirow{7}{*}{ 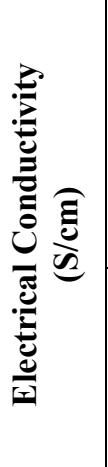 } & \multirow{4}{*}{ 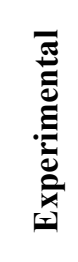 } & Temperature 1 & - \\
\hline & & Temperature 2 & - \\
\hline & & Temperature 3 & - \\
\hline & & Temperature 4 & - \\
\hline & \multirow{3}{*}{ 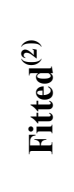 } & $1050^{\circ} \mathrm{C}$ & - \\
\hline & & $1150^{\circ} \mathrm{C}$ & - \\
\hline & & $1250^{\circ} \mathrm{C}$ & - \\
\hline \multirow{3}{*}{\multicolumn{2}{|c|}{ 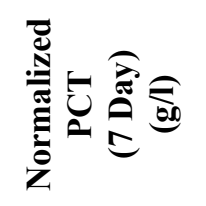 }} & B & - \\
\hline & & $\mathrm{Li}$ & - \\
\hline & & $\mathrm{Na}$ & - \\
\hline \multirow{3}{*}{\multicolumn{2}{|c|}{ 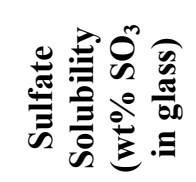 }} & Target ${ }^{(3)}$ & $0.95 \%$ \\
\hline & & Over-Saturation & $1.12 \%$ \\
\hline & & Gas Bubbling & - \\
\hline
\end{tabular}


Table 2.11. Regression Results ${ }^{(1)}$, Estimated One-Percent Crystal Fraction Temperature $\left(T_{1 \%}\right)$, and the Major Crystalline Phase Near $T_{1 \%}$ for the HLWS Series of Glasses.

\begin{tabular}{|c|c|c|c|c|}
\hline Glass & Intercept & Slope & $\mathbf{T}_{\mathbf{1} \%}\left({ }^{\circ} \mathbf{C}\right)$ & $\begin{array}{c}\text { Primary Crystalline } \\
\text { Phase }\end{array}$ \\
\hline \hline HLWS-21 & 989.78 & -42.92 & 946.86 & Spinel \\
\hline HLWS-22 & 991.30 & -78.02 & 913.28 & Spinel/Calcium Phosphate \\
\hline HLWS-23 & 981.67 & -43.91 & 937.76 & Spinel \\
\hline HLWS-24 & 1004.76 & -41.34 & 963.42 & Spinel \\
\hline HLWS-25 & 1006.20 & -34.50 & 971.70 & Spinel \\
\hline HLWS-26 & 1001.11 & -35.28 & 965.83 & Spinel/Calcium Phosphate \\
\hline HLWS-27 & 1001.21 & -35.05 & 966.17 & Spinel/Calcium Phosphate \\
\hline HLWS-28 & 1015.65 & -38.91 & 976.74 & Spinel \\
\hline HLWS-29 & 1011.38 & -37.45 & 973.93 & Spinel \\
\hline HLWS-30 & 1007.89 & -43.33 & 964.56 & Spinel \\
\hline HLWS-31 & 1077.27 & -136.85 & 940.42 & Spinel \\
\hline HLWS-32 & 1007.74 & -37.41 & 970.33 & Spinel \\
\hline HLWS-33 & 1029.17 & -44.40 & 984.77 & \\
\hline (1) Regression results are rounded to 2 decimal places. & & & Spinel/Calcium Phosphate \\
\hline
\end{tabular}


Table 2.12. Ranking Definition for Feed Conversion after 30 Minute VGF Test.

\begin{tabular}{|l|l|}
\hline 1 & Very Fast, all feed converted \\
\hline 2 & Fast with minor residue on side wall \\
\hline 3 & Moderate with foamy residue on side wall \\
\hline 4 & Slow with thick foam layer \\
\hline 5 & Slow with partially collapsed dome \\
\hline 6 & Very slow with fully developed dome \\
\hline
\end{tabular}

Table 2.13. TCLP Results (ppm) for Selected HLWS Glasses.

\begin{tabular}{|c|c|c|c|c|c|c|}
\hline Element & HLWS-24 & HLWS-27 & HLWS-28 & HLWS-32 & $\begin{array}{c}\text { Universal } \\
\text { Treatment } \\
\text { Standard } \\
\text { Limit }\end{array}$ & $\begin{array}{c}\text { Delisting } \\
\text { Limit }\end{array}$ \\
\hline \hline $\mathrm{Ba}$ & 0.01 & 0.02 & 0.05 & 0.03 & 21 & 100 \\
\hline $\mathrm{Cr}$ & 0.09 & 0.10 & 2.66 & 1.17 & 0.6 & 4.95 \\
\hline $\mathrm{Ni}$ & 0.31 & 0.42 & 0.39 & 0.29 & 11 & 22.6 \\
\hline $\mathrm{Pb}$ & $<0.1$ & $<0.1$ & $<0.1$ & $<0.1$ & 0.75 & 5 \\
\hline
\end{tabular}

(1) Not applicable to HLW glass because vitrification is the US Environmental Protection Agency Best Demonstrated Available Technology (BDAT). For comparison only. 
Table 3.1. Compositions of Three HLW Glasses for Metal Corrosion Tests (note that $\mathrm{B}_{2} \mathrm{O}_{3}$, $\mathrm{Li}_{2} \mathrm{O}$ and $\mathrm{F}$ were not analyzed by $\mathrm{XRF}$, target values are used).

\begin{tabular}{|c|c|c|c|c|c|}
\hline Glass Name & \multicolumn{2}{|c|}{ HLWS-09 } & HLW-NG-Fe2 & \multirow{2}{*}{\multicolumn{2}{|c|}{$\begin{array}{c}\text { HLWS-27 } \\
\text { HLWS-27R1 }\end{array}$}} \\
\hline $\begin{array}{c}\text { Glass Sample } \\
\text { ID }\end{array}$ & $10 Y-G-63 A$ & $\begin{array}{l}10 \mathrm{Y}-\mathrm{G}- \\
59 \mathrm{C}\end{array}$ & $10 \mathrm{~W}-\mathrm{G}-116$ & & \\
\hline Sample Origin & Melter & Melter & Melter & \multicolumn{2}{|c|}{ Crucible } \\
\hline Data Type & $\mathrm{XRF}$ & XRF & $\mathrm{XRF}$ & TARGET & XRF \\
\hline $\mathrm{Al}_{2} \mathrm{O}_{3}$ & 7.50 & 7.39 & 6.05 & 8.19 & 7.96 \\
\hline $\mathrm{B}_{2} \mathrm{O}_{3}$ & 8.47 & 8.47 & 13.77 & 9.70 & 9.70 \\
\hline $\mathrm{BaO}$ & 0.00 & 0.00 & 0.11 & 0.00 & 0.00 \\
\hline $\mathbf{B i}_{2} \mathbf{O}_{3}$ & 2.10 & 2.19 & 0.01 & 1.26 & 1.32 \\
\hline $\mathrm{CaO}$ & 8.45 & 8.49 & 0.59 & 8.34 & 8.61 \\
\hline $\mathrm{CeO}_{2}$ & 0.00 & 0.00 & 0.08 & 0.00 & 0.00 \\
\hline $\mathrm{Cr}_{2} \mathrm{O}_{3}$ & 0.44 & 0.48 & 0.26 & 0.94 & 0.92 \\
\hline $\mathbf{F}$ & 0.44 & 0.43 & 0.00 & 0.72 & 0.72 \\
\hline $\mathrm{Fe}_{2} \mathrm{O}_{3}$ & 2.06 & 2.06 & 15.51 & 5.41 & 5.16 \\
\hline $\mathrm{K}_{2} \mathrm{O}$ & 0.62 & 0.64 & 0.45 & 0.28 & 0.30 \\
\hline $\mathrm{La}_{2} \mathrm{O}_{3}$ & 0.71 & 0.61 & 0.10 & 0.00 & 0.00 \\
\hline $\mathbf{L i}_{2} \mathbf{O}$ & 4.96 & 4.96 & 1.55 & 2.50 & 2.50 \\
\hline MgO & 0.23 & 0.24 & 0.33 & 0.13 & 0.11 \\
\hline MnO & 0.81 & 1.07 & 2.61 & 4.52 & 4.50 \\
\hline $\mathrm{Na}_{2} \mathrm{O}$ & 9.92 & 9.70 & 13.24 & 12.45 & 12.48 \\
\hline $\mathrm{NiO}$ & 1.51 & 1.50 & 0.48 & 0.87 & 0.94 \\
\hline $\mathbf{P}_{2} \mathbf{O}_{5}$ & 3.17 & 3.44 & 0.63 & 1.56 & 1.58 \\
\hline PbO & 0.10 & 0.09 & 0.51 & 0.19 & 0.18 \\
\hline $\mathrm{SO}_{3}$ & 1.64 & 1.60 & 0.36 & 0.95 & 0.94 \\
\hline $\mathrm{SiO}_{2}$ & 41.50 & 41.07 & 41.92 & 40.89 & 40.80 \\
\hline $\mathrm{SnO}_{2}$ & 0.00 & 0.00 & 0.09 & 0.00 & 0.00 \\
\hline SrO & 0.01 & 0.01 & 0.17 & 1.03 & 0.98 \\
\hline $\mathrm{TiO}_{2}$ & 0.17 & 0.18 & 0.09 & 0.00 & 0.02 \\
\hline $\mathrm{V}_{2} \mathrm{O}_{5}$ & 1.94 & 1.96 & 0.00 & 0.00 & 0.00 \\
\hline $\mathrm{ZnO}$ & 0.02 & 0.02 & $0 . .08$ & 0.00 & 0.01 \\
\hline $\mathrm{ZrO}_{2}$ & 3.22 & 3.36 & 1.00 & 0.07 & 0.25 \\
\hline Sum & 99.99 & 99.96 & 99.91 & 100.00 & 99.98 \\
\hline
\end{tabular}


Table 3.2. Metal Corrosion Test Conditions.

\begin{tabular}{|c|c|c|c|c|c|c|}
\hline Alloy Type & Glass Type & Glass Sample ID & Test Condition & $\begin{array}{c}\text { Starting } \mathrm{SO}_{3}, \\
\text { wt } \%\end{array}$ & $\begin{array}{c}\text { Finishing } \mathrm{SO}_{3} \mathrm{wt}^{\circ} \\
\left(\text { duration }^{* 3}\right)\end{array}$ & $\begin{array}{c}\text { Metal Sample } \\
\text { ID } \\
\end{array}$ \\
\hline \multirow{4}{*}{ Inconel 690} & HLW-NG-Fe2 & $10 \mathrm{~W}-\mathrm{G}-116 \mathrm{~A}$ & 7 Day Standard ${ }^{* 1}$ & 0.36 & $0.06(2 \mathrm{~d}), 0.07(2 \mathrm{~d}), 0.04(3 \mathrm{~d})$ & INC690-02 \\
\hline & \multirow{2}{*}{ HLWS-09 } & 10Y-G-63A & 7 Day Standard & 1.64 & $0.21(2 \mathrm{~d}), 0.15(2 \mathrm{~d}), 0.09(3 \mathrm{~d})$ & INC690-01 \\
\hline & & $10 \mathrm{Y}-\mathrm{G}-59 \mathrm{C}$ & 7 Day Sealed $^{* 2}$ & 1.60 & $0.79(7 \mathrm{~d})$ & INC690-05 \\
\hline & HLWS-27 & HLWS-27R1 & 7 Day Sealed & 0.95 & $0.92(7 d)$ & INC690-07 \\
\hline \multirow{4}{*}{ MA 758} & HLW-NG-Fe2 & $10 \mathrm{~W}-\mathrm{G}-116 \mathrm{~A}$ & 7 Day Standard & 0.36 & $0.04(2 \mathrm{~d}), 0.05(2 \mathrm{~d}), 0.02(3 \mathrm{~d})$ & MA758-4 \\
\hline & \multirow{2}{*}{ HLWS-09 } & 10Y-G-63A & 7 Day Standard & 1.64 & $0.15(2 \mathrm{~d}), 0.17(2 \mathrm{~d}), 0.08(3 \mathrm{~d})$ & MA758-3 \\
\hline & & 10Y-G-59C & 7 Day Sealed & 1.60 & $1.40(7 \mathrm{~d})$ & MA758-6 \\
\hline & HLWS-27 & HLWS-27R1 & 7 Day Sealed & 0.95 & $0.95(7 d)$ & MA758-8 \\
\hline
\end{tabular}

*1: Standard 7-day metal corrosion tests with glass melt replacement after the second and fourth days from the starting time.

*2: Modified 7-day metal corrosion tests in a sealed crucible.

*3: $\mathrm{SO}_{3} \mathrm{wt} \%$ by XRF. (\#d) stands for the total duration (number of days) for a continuous metal corrosion test. Note that 7-day standard corrosion tests involved replacement of glass melts after the second and fourth days from the starting point. 
Table 3.3. XRF Analysis of Glass Composition after Metal Corrosion Tests.

\begin{tabular}{|c|c|c|c|c|c|c|c|c|c|c|c|c|c|c|c|c|c|c|c|}
\hline Glass Type & $\begin{array}{c}\text { HLWS- } \\
09\end{array}$ & $\begin{array}{c}\text { HLWS- } \\
09\end{array}$ & $\begin{array}{c}\text { HLWS- } \\
09\end{array}$ & $\begin{array}{c}\text { HLWS- } \\
09\end{array}$ & $\begin{array}{c}\text { HLWS- } \\
09\end{array}$ & $\begin{array}{c}\text { HLWS- } \\
09\end{array}$ & $\begin{array}{c}\text { HLWS- } \\
09\end{array}$ & $\begin{array}{c}\text { HLWS- } \\
09\end{array}$ & $\begin{array}{c}\text { HLWS- } \\
09\end{array}$ & $\begin{array}{l}\text { HLW- } \\
\text { NG- } \\
\mathrm{Fe} 2 \\
\end{array}$ & $\begin{array}{l}\text { HLW- } \\
\text { NG- } \\
\mathrm{Fe} 2 \\
\end{array}$ & $\begin{array}{l}\text { HLW- } \\
\text { NG- } \\
\text { Fe2 } \\
\end{array}$ & $\begin{array}{c}\text { HLW- } \\
\text { NG-Fe2 }\end{array}$ & $\begin{array}{l}\text { HLW- } \\
\text { NG-Fe2 }\end{array}$ & $\begin{array}{l}\text { HLW- } \\
\text { NG-Fe2 }\end{array}$ & $\begin{array}{c}\text { HLW- } \\
\text { NG-Fe2 }\end{array}$ & $\begin{array}{c}\text { HLWS- } \\
27\end{array}$ & $\begin{array}{c}\text { HLWS- } \\
27\end{array}$ & $\begin{array}{c}\text { HLWS- } \\
27\end{array}$ \\
\hline Sample ID & $\begin{array}{c}10 \mathrm{Y}-\mathrm{G}- \\
63 \mathrm{~A}\end{array}$ & $\begin{array}{c}\text { HLWS- } \\
09-11\end{array}$ & $\begin{array}{c}\text { HLWS- } \\
09-12\end{array}$ & $\begin{array}{c}\text { HLWS- } \\
09-13\end{array}$ & $\begin{array}{c}\text { HLWS- } \\
09-14\end{array}$ & $\begin{array}{c}\text { HLWS- } \\
09-15\end{array}$ & $\begin{array}{c}\text { HLWS- } \\
09-16\end{array}$ & $\begin{array}{c}\text { HLWS- } \\
09-18\end{array}$ & $\begin{array}{c}\text { HLWS- } \\
09-19\end{array}$ & $\begin{array}{c}10 \mathrm{~W}- \\
\mathrm{G}- \\
116 \mathrm{~A}\end{array}$ & $\begin{array}{l}\text { HLW- } \\
\text { NG- } \\
\text { FE2-11 }\end{array}$ & $\begin{array}{l}\text { HLW- } \\
\text { NG- } \\
\text { FE2-12 }\end{array}$ & $\begin{array}{l}\text { HLW- } \\
\text { NG- } \\
\text { FE2-13 }\end{array}$ & $\begin{array}{l}\text { HLW- } \\
\text { NG- } \\
\text { FE2-14 }\end{array}$ & $\begin{array}{l}\text { HLW- } \\
\text { NG- } \\
\text { FE2-15 }\end{array}$ & $\begin{array}{l}\text { HLW- } \\
\text { NG- } \\
\text { FE2-16 }\end{array}$ & $\begin{array}{l}\text { HLWS- } \\
\text { 27R1 }\end{array}$ & $\begin{array}{c}\text { HLWS- } \\
27-1\end{array}$ & $\begin{array}{c}\text { HLWS- } \\
27-2\end{array}$ \\
\hline Experiment & $\begin{array}{c}\text { Starting } \\
\text { Glass }\end{array}$ & \multicolumn{3}{|c|}{ Standard Corrosion } & \multicolumn{3}{|c|}{ Standard Corrosion } & $\begin{array}{c}\text { Sealed } \\
\text { Corrosion }\end{array}$ & $\begin{array}{c}\text { Sealed } \\
\text { Corrosion }\end{array}$ & $\begin{array}{c}\text { Starting } \\
\text { Glass }\end{array}$ & \multicolumn{3}{|c|}{ Standard Corrosion } & \multicolumn{3}{|c|}{ Standard Corrosion } & $\begin{array}{c}\text { Starting } \\
\text { Glass }\end{array}$ & $\begin{array}{c}\text { Sealed } \\
\text { Corrosion }\end{array}$ & $\begin{array}{c}\text { Sealed } \\
\text { Corrosion }\end{array}$ \\
\hline $\begin{array}{c}\text { Alloy } \\
\text { Tested }\end{array}$ & - & \multicolumn{3}{|c|}{ Inconel 690} & \multicolumn{3}{|c|}{ MA758 } & $\begin{array}{c}\text { Inconel } \\
690\end{array}$ & MA758 & - & \multicolumn{3}{|c|}{ Inconel 690} & \multicolumn{3}{|c|}{ MA758 } & - & $\begin{array}{c}\text { Inconel } \\
690\end{array}$ & MA758 \\
\hline $\begin{array}{c}\text { Duration } \\
\text { (a) } 1150^{\circ} \mathrm{C}\end{array}$ & - & 2 days & $\begin{array}{c}\text { 2nd } \\
\text { 2days }\end{array}$ & 3 days & 2 days & $\begin{array}{c}2 \text { 2nd } 2 \\
\text { days }\end{array}$ & 3 days & 7 days & 7 days & - & 2 days & $\begin{array}{c}\text { 2nd } \\
2 \text { days }\end{array}$ & 3 days & 2 days & $\begin{array}{c}\text { 2nd } \\
\text { 2days }\end{array}$ & 3 days & - & 7 days & 7 days \\
\hline $\begin{array}{c}\text { Starting } \\
\text { Materials } \\
(\mathrm{g})\end{array}$ & - & 70.12 & 70.20 & 70.03 & 70.08 & 70.18 & 70.01 & 70.08 & 69.98 & - & 70.03 & 70.15 & 70.08 & 70.12 & 70.10 & 70.03 & - & 70.10 & 70.02 \\
\hline $\mathrm{Al}_{2} \mathrm{O}_{3}$ & 7.50 & 7.46 & 7.57 & 7.58 & 7.64 & 7.50 & 7.61 & 7.83 & 7.46 & 6.05 & 6.29 & 6.35 & 6.36 & 6.27 & 6.41 & 6.34 & 8.19 & 8.41 & 8.47 \\
\hline $\mathrm{B}_{2} \mathrm{O}_{3}$ & 8.47 & 8.47 & 8.47 & 8.47 & 8.47 & 8.47 & 8.47 & 8.47 & 8.47 & 13.77 & 13.77 & 13.77 & 13.77 & 13.77 & 13.77 & 13.77 & 9.70 & 9.70 & 9.70 \\
\hline $\mathrm{BaO}$ & & & & & & & & & & 0.11 & 0.11 & 0.11 & 0.13 & 0.10 & 0.09 & 0.11 & - & - & - \\
\hline $\mathrm{Bi}_{2} \mathrm{O}_{3}$ & 2.10 & 2.20 & 2.16 & 2.18 & 2.14 & 2.16 & 2.16 & 2.10 & 2.15 & 0.01 & 0.02 & 0.02 & 0.01 & 0.01 & 0.02 & & 1.26 & 1.40 & 1.41 \\
\hline $\mathrm{CaO}$ & 8.45 & 8.77 & 8.55 & 8.55 & 8.45 & 8.64 & 8.47 & 8.33 & 8.53 & 0.59 & 0.72 & 0.69 & 0.63 & 0.64 & 0.67 & 0.63 & 8.34 & 8.73 & 8.83 \\
\hline $\mathrm{CdO}$ & 0.00 & - & - & - & - & - & - & - & - & 0.02 & 0.02 & 0.02 & 0.02 & 0.02 & 0.02 & 0.02 & - & - & - \\
\hline $\mathrm{CeO}_{2}$ & - & - & - & - & - & - & - & - & - & 0.08 & 0.09 & 0.11 & 0.12 & 0.14 & 0.10 & 0.12 & - & - & - \\
\hline $\mathrm{Cl}$ & 0.01 & - & - & - & 0.01 & - & - & - & 0.01 & - & 0.01 & - & - & - & 0.01 & - & - & - & 0.01 \\
\hline $\mathrm{Cr}_{2} \mathrm{O}_{3}$ & 0.44 & 0.52 & 0.52 & 0.53 & 0.48 & 0.55 & 0.54 & 0.63 & 0.56 & 0.26 & 0.24 & 0.23 & 0.25 & 0.25 & 0.25 & 0.26 & 0.94 & 0.39 & 0.35 \\
\hline $\mathrm{F}$ & 0.44 & - & - & - & - & - & - & 0.00 & 0.00 & - & - & - & - & - & - & - & 0.72 & 0.72 & 0.72 \\
\hline $\mathrm{Fe}_{2} \mathrm{O}_{3}$ & 2.06 & 2.06 & 2.22 & 2.22 & 2.15 & 2.15 & 2.02 & 1.98 & 2.09 & 15.51 & 15.04 & 14.62 & 14.84 & 14.57 & 15.14 & 14.93 & 5.41 & 5.09 & 5.18 \\
\hline $\mathrm{HfO}_{2}$ & - & 0.06 & 0.06 & 0.07 & 0.06 & 0.06 & 0.06 & 0.06 & 0.07 & - & 0.01 & 0.01 & 0.03 & 0.02 & 0.02 & 0.02 & - & - & - \\
\hline $\mathrm{K}_{2} \mathrm{O}$ & 0.62 & 0.60 & 0.56 & 0.58 & 0.56 & 0.57 & 0.54 & 0.52 & 0.50 & 0.45 & 0.29 & 0.35 & 0.32 & 0.35 & 0.33 & 0.35 & 0.28 & 0.26 & 0.28 \\
\hline $\mathrm{La}_{2} \mathrm{O}_{3}$ & 0.71 & 0.43 & 0.46 & 0.44 & 0.41 & 0.43 & 0.37 & 0.45 & 0.39 & 0.10 & 0.07 & 0.06 & 0.07 & 0.07 & 0.05 & 0.06 & 0.00 & - & - \\
\hline $\mathrm{Li}_{2} \mathrm{O}$ & 4.96 & 4.96 & 4.96 & 4.96 & 4.96 & 4.96 & 4.96 & 4.96 & 4.96 & 1.55 & 1.55 & 1.55 & 1.55 & 1.55 & 1.55 & 1.55 & 2.50 & 2.50 & 2.50 \\
\hline $\mathrm{MgO}$ & 0.23 & 0.26 & 0.25 & 0.30 & 0.26 & 0.25 & 0.30 & 0.28 & 0.28 & 0.33 & 0.35 & 0.38 & 0.33 & 0.35 & 0.35 & 0.37 & 0.13 & 0.11 & 0.11 \\
\hline $\mathrm{MnO}$ & 0.81 & 0.93 & 0.87 & 0.90 & 0.86 & 0.89 & 0.86 & 1.12 & 1.12 & 2.61 & 2.67 & 2.65 & 2.61 & 2.56 & 2.66 & 2.69 & 4.52 & 4.54 & 4.37 \\
\hline $\mathrm{Na}_{2} \mathrm{O}$ & 9.92 & 9.96 & 10.11 & 10.01 & 10.17 & 10.13 & 10.46 & 9.27 & 9.18 & 13.24 & 12.43 & 13.02 & 12.66 & 12.65 & 12.40 & 12.39 & 12.45 & 11.79 & 11.64 \\
\hline $\mathrm{NiO}$ & 1.51 & 1.52 & 1.53 & 1.52 & 1.48 & 1.50 & 1.54 & 1.56 & 1.54 & 0.48 & 0.49 & 0.48 & 0.50 & 0.47 & 0.48 & 0.47 & 0.87 & 0.88 & 0.84 \\
\hline $\mathrm{P}_{2} \mathrm{O}_{5}$ & 3.17 & 2.80 & 2.72 & 2.74 & 2.78 & 2.74 & 2.74 & 3.14 & 3.02 & 0.63 & 0.57 & 0.59 & 0.56 & 0.58 & 0.58 & 0.58 & 1.56 & 1.61 & 1.58 \\
\hline $\mathrm{PbO}$ & 0.10 & 0.10 & 0.11 & 0.10 & 0.10 & 0.09 & 0.09 & 0.09 & 0.09 & 0.51 & 0.46 & 0.44 & 0.43 & 0.43 & 0.45 & 0.43 & 0.19 & 0.19 & 0.18 \\
\hline $\mathrm{Rb}_{2} \mathrm{O}$ & - & - & - & - & 0.04 & 0.04 & 0.05 & 0.00 & - & - & - & - & - & - & - & - & - & - & - \\
\hline $\mathrm{SO}_{3}$ & 1.64 & 0.21 & 0.15 & $\begin{array}{l}0.09 \\
\end{array}$ & 0.15 & 0.17 & 0.08 & $\begin{array}{l}0.79 \\
\end{array}$ & 1.40 & 0.36 & 0.06 & 0.07 & 0.04 & 0.04 & 0.05 & 0.02 & 0.95 & 0.92 & 0.95 \\
\hline $\mathrm{SiO}_{2}$ & 41.50 & 42.92 & 43.14 & 43.19 & 43.35 & 43.17 & 43.10 & 42.95 & 42.52 & 41.92 & 43.26 & 43.07 & 43.37 & 43.76 & 43.15 & 43.48 & 40.89 & 41.46 & 41.60 \\
\hline $\mathrm{SnO}_{2}$ & - & - & - & - & - & - & - & - & - & 0.09 & 0.09 & 0.09 & 0.08 & $\begin{array}{l}0.09 \\
\end{array}$ & 0.09 & 0.09 & - & - & - \\
\hline SrO & 0.01 & 0.01 & 0.01 & 0.01 & 0.01 & 0.01 & 0.00 & 0.01 & 0.01 & 0.17 & 0.17 & 0.17 & 0.17 & 0.17 & 0.17 & 0.18 & 1.03 & 1.02 & $\begin{array}{l}1.01 \\
\end{array}$ \\
\hline $\mathrm{TiO}_{2}$ & 0.17 & 0.17 & 0.17 & 0.16 & 0.16 & 0.18 & 0.17 & 0.18 & 0.19 & 0.09 & 0.10 & 0.09 & 0.10 & 0.09 & 0.09 & 0.08 & - & 0.03 & 0.03 \\
\hline $\mathrm{V}_{2} \mathrm{O}_{5}$ & 1.94 & 2.11 & 2.05 & 2.07 & 2.02 & 2.00 & 2.06 & 1.98 & 2.01 & - & - & - & - & - & - & - & - & - & - \\
\hline $\mathrm{Y}_{2} \mathrm{O}_{3}$ & - & - & - & - & 0.01 & 0.01 & 0.01 & 0.00 & 0.09 & - & - & - & - & - & - & - & - & - & - \\
\hline $\mathrm{ZnO}$ & 0.02 & 0.02 & 0.02 & 0.02 & 0.02 & 0.02 & 0.02 & 0.02 & 0.02 & $0 . .08$ & 0.08 & 0.09 & 0.08 & 0.08 & 0.10 & 0.07 & - & 0.01 & 0.00 \\
\hline $\mathrm{ZrO}_{2}$ & 3.22 & 3.45 & 3.30 & 3.32 & 3.28 & 3.32 & 3.32 & 3.28 & 3.36 & 1.00 & 1.04 & 0.99 & 1.00 & 0.97 & 1.01 & 0.99 & 0.07 & 0.26 & 0.26 \\
\hline sum & 100.00 & 999.99 & 99.93 & 100.00 & 100.00 & 100.00 & 100.00 & 100.00 & 999.99 & 99.93 & 99.99 & 99.99 & 100.00 & 100.00 & 100.00 & 100.00 & 100.00 & 100.00 & 100.00 \\
\hline
\end{tabular}


Table 3.4. Summary of Key Observations of Metal Coupons after Corrosion Test.

\begin{tabular}{|c|c|c|c|c|c|c|c|c|c|}
\hline \multirow{4}{*}{ 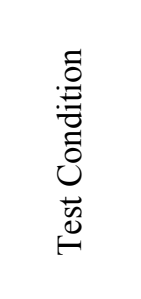 } & Alloy Type & $\begin{array}{c}\text { INCONEL } \\
690\end{array}$ & MA758 & $\begin{array}{c}\text { INCONEL } \\
690\end{array}$ & MA758 & $\begin{array}{c}\text { INCONEL } \\
690\end{array}$ & MA758 & $\begin{array}{c}\text { INCONEL } \\
690\end{array}$ & MA758 \\
\hline & Metal Coupon ID & INC690-01 & MA758-3 & INC690-02 & MA758-4 & INC690-05 & MA758-6 & INC690-07 & MA758-8 \\
\hline & Test Method & \multicolumn{4}{|c|}{ Standard } & \multicolumn{4}{|c|}{ Sealed Crucible } \\
\hline & Glass Type & \multicolumn{2}{|c|}{ HLWS-09 } & \multicolumn{2}{|c|}{ HLW-NG-Fe2 } & \multicolumn{2}{|c|}{ HLWS-09 } & \multicolumn{2}{|c|}{ HLWS-27 } \\
\hline \multirow{2}{*}{$\begin{array}{l}\infty \\
\infty \\
0 \\
0\end{array}$} & Neck loss (mil)* & 6 & 1 & 1 & 0 & 4 & 0 & $<1$ & $<1$ \\
\hline & Half-down loss (mil) & 0 & 0 & 0 & 0 & 1 & 0 & 0 & 0 \\
\hline \multirow{3}{*}{ 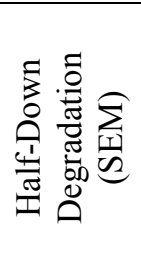 } & $\mathrm{Cr} \%$ near surface & $18 \%$ & $27 \%$ & $15 \%$ & $26 \%$ & $6 \%$ & $26 \%$ & $24 \%$ & $27 \%$ \\
\hline & $\begin{array}{l}\text { Internal damage depth } \\
(\mu \mathrm{m})\end{array}$ & 70 & 65 & 140 & 85 & 130 & 185 & 60 & 90 \\
\hline & $\begin{array}{c}\text { Cr depletion depth } \\
(\mu \mathrm{m})\end{array}$ & 300 & 300 & 300 & 300 & 300 & 300 & 300 & 300 \\
\hline \multirow{3}{*}{ 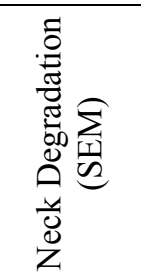 } & $\mathrm{Cr} \%$ near surface & $10 \%$ & $10 \%$ & $22 \%$ & $27 \%$ & $8 \%$ & $25 \%$ & $22 \%$ & $25 \%$ \\
\hline & $\begin{array}{l}\text { Internal damage depth } \\
\qquad(\mu \mathrm{m})\end{array}$ & 160 & 320 & 140 & 130 & 320 & 140 & 70 & 70 \\
\hline & $\begin{array}{l}\text { Cr depletion depth } \\
(\mu \mathrm{m})\end{array}$ & 350 & 350 & 300 & 300 & 350 & 350 & 300 & 300 \\
\hline
\end{tabular}


ORP-56310 Rev. 0

The Catholic University of America

Management of High Sulfur HLW

Vitreous State Laboratory

Final Report, VSL-13R2920-1, Rev. 0

Table 4.1. Summary of DM10 Melter Tests with HLWS-27 Glass Formulation.

\begin{tabular}{|c|c|c|c|c|}
\hline \multicolumn{2}{|r|}{ Test } & $\mathbf{A}$ & B & C \\
\hline & Feeding Interval & $\begin{array}{c}5 / 29 / 139: 30- \\
5 / 30 / 135: 30\end{array}$ & $\begin{array}{c}5 / 30 / 139: 00- \\
5 / 31 / 135: 30\end{array}$ & $\begin{array}{c}5 / 31 / 137: 00- \\
6 / 1 / 133: 30\end{array}$ \\
\hline & Interruptions & 0 & 14 minutes & 0 \\
\hline & Total & $20.0 \mathrm{hr}$ & $20.5 \mathrm{hr}$ & $20.5 \mathrm{hr}$ \\
\hline \multirow{3}{*}{ Feed } & Target $\mathrm{SO}_{3}$ Conc. (wt $\%$ ) & 0.953 & 1.3 & 1.5 \\
\hline & Processed $(\mathrm{kg})$ & 58.60 & 59.11 & 54.33 \\
\hline & Processing rate $(\mathrm{kg} / \mathrm{hr})$ & 2.9 & 2.9 & 2.7 \\
\hline \multirow{5}{*}{ Glass } & Produced from feed $(\mathrm{kg})$ & 19.34 & 19.50 & 17.93 \\
\hline & Discharged $(\mathrm{kg})$ & 18.54 & 18.10 & 18.58 \\
\hline & $\begin{array}{l}\text { Test Average Production } \\
\text { Rate }\left(\mathrm{kg} / \mathrm{m}^{2} / \text { day }\right)^{*}\end{array}$ & 1105 & 1087 & 1000 \\
\hline & Measured $\mathrm{SO}_{3}$ Conc. (wt\%) & 0.71 & 0.94 & 1.04 \\
\hline & $\begin{array}{l}\text { Secondary sulfate phase on } \\
\text { glass pool samples }\end{array}$ & 0 of $3^{\#}$ & 0 of $3^{\#}$ & 0 of $3^{\#}$ \\
\hline \multirow{2}{*}{$\begin{array}{l}\text { Test Average Glass } \\
\text { Temperature }\left({ }^{\circ} \mathrm{C}\right)\end{array}$} & 2" from floor & 1154 & 1155 & 1156 \\
\hline & 4" from floor & 1141 & 1137 & 1136 \\
\hline \multirow{2}{*}{$\begin{array}{l}\text { Test Average Plenum } \\
\text { Temperature }\left({ }^{\circ} \mathrm{C}\right) \\
\end{array}$} & Exposed & 501 & 542 & 527 \\
\hline & Thermowell & 501 & 535 & 518 \\
\hline \multicolumn{2}{|c|}{ Test Average Electrode Temperature $\left({ }^{\circ} \mathrm{C}\right)$} & 1061 & 1061 & 1055 \\
\hline \multicolumn{2}{|c|}{ Test Average Discharge Chamber Temperature $\left({ }^{\circ} \mathrm{C}\right)$} & 1044 & 1057 & 1060 \\
\hline \multicolumn{2}{|c|}{$\begin{array}{l}\text { Test Average Film Cooler Exhaust Outlet Temperature } \\
\qquad\left({ }^{\circ} \mathrm{C}\right)\end{array}$} & 288 & 292 & 289 \\
\hline \multicolumn{2}{|c|}{ Test Average Melter Pressure (inches water) } & -0.9 & -1.0 & -1.0 \\
\hline \multicolumn{2}{|c|}{ Test Average Melt Pool Bubbling (lpm) } & 1.9 & 1.4 & 1.5 \\
\hline \multirow{4}{*}{$\begin{array}{c}\text { Test Average } \\
\text { Electrical Properties }\end{array}$} & Voltage (volts) & 30.4 & 32.0 & 32.1 \\
\hline & Current (amps) & 163 & 159 & 161 \\
\hline & Power $(\mathrm{kW})$ & 5.0 & 5.1 & 5.2 \\
\hline & Glass Pool Resistance (ohms) & 0.187 & 0.201 & 0.199 \\
\hline
\end{tabular}

* - Calculated from total feed processed

NA - Not Applicable

\# - Refers to number of dip samples with secondary phase 
Table 4.1. Summary of DM10 Melter Tests with HLWS-27 Glass Formulation (continued).

\begin{tabular}{|c|c|c|c|}
\hline \multicolumn{2}{|r|}{ Test } & D & $\mathbf{E}$ \\
\hline & Feeding Interval & $\begin{array}{c}6 / 3 / 139: 40- \\
6 / 4 / 136: 00\end{array}$ & $\begin{array}{c}6 / 4 / 1312: 45- \\
6 / 5 / 1311: 00\end{array}$ \\
\hline & Interruptions & 0 & 0 \\
\hline & Total & $20.3 \mathrm{hr}$ & $22.3 \mathrm{hr}$ \\
\hline \multirow{3}{*}{ Feed } & Target $\mathrm{SO}_{3}$ Conc. (wt\%) & 1.78 & 1.63 \\
\hline & Processed $(\mathrm{kg})$ & 60.35 & 62.16 \\
\hline & Processing rate $(\mathrm{kg} / \mathrm{hr})$ & 3.0 & 2.8 \\
\hline \multirow{5}{*}{ Glass } & Produced from feed $(\mathrm{kg})$ & 19.91 & 20.51 .1 \\
\hline & Discharged $(\mathrm{kg})$ & 18.06 & 19.30 \\
\hline & $\begin{array}{l}\text { Test Average Production } \\
\text { Rate }\left(\mathrm{kg} / \mathrm{m}^{2} / \text { day }\right)^{*} \\
\end{array}$ & 1119 & 1054 \\
\hline & Measured $\mathrm{SO}_{3}$ Conc. $(\mathrm{wt} \%)$ & 1.23 & 1.13 \\
\hline & $\begin{array}{l}\text { Secondary sulfate phase on } \\
\text { glass pool samples }\end{array}$ & 2 of $3^{\#}$ & 0 of $3^{\#}$ \\
\hline \multirow{2}{*}{$\begin{array}{l}\text { Test Average Glass } \\
\text { Temperature }\left({ }^{\circ} \mathrm{C}\right)\end{array}$} & 2" from floor & 1156 & 1156 \\
\hline & 4" from floor & 1141 & 1139 \\
\hline \multirow{2}{*}{$\begin{array}{l}\text { Test Average Plenum } \\
\text { Temperature }\left({ }^{\circ} \mathrm{C}\right) \\
\end{array}$} & Exposed & 536 & 544 \\
\hline & Thermowell & 529 & 530 \\
\hline \multicolumn{2}{|c|}{ Test Average Electrode Temperature $\left({ }^{\circ} \mathrm{C}\right)$} & 1024 & 1030 \\
\hline \multicolumn{2}{|c|}{ Test Average Discharge Chamber Temperature $\left({ }^{\circ} \mathrm{C}\right)$} & 1039 & 1056 \\
\hline \multicolumn{2}{|c|}{$\begin{array}{l}\text { Test Average Film Cooler Exhaust Outlet Temperature } \\
\qquad\left({ }^{\circ} \mathrm{C}\right)\end{array}$} & 284 & 284 \\
\hline \multicolumn{2}{|c|}{ Test Average Melter Pressure (inches water) } & -1.0 & -1.0 \\
\hline \multicolumn{2}{|c|}{ Test Average Melt Pool Bubbling (lpm) } & 1.6 & 1.9 \\
\hline \multirow{4}{*}{$\begin{array}{c}\text { Test Average } \\
\text { Electrical Properties }\end{array}$} & Voltage (volts) & 30.3 & 31.5 \\
\hline & Current (amps) & 161 & 164 \\
\hline & Power $(\mathrm{kW})$ & 4.9 & 5.2 \\
\hline & Glass Pool Resistance (ohms) & 0.188 & 0.192 \\
\hline
\end{tabular}

* - Calculated from total feed processed

NA - Not Applicable

\# - Refers to number of dip samples with secondary phase 
The Catholic University of America

Table 5.1. Characteristics of Feed Samples.

\begin{tabular}{|c|c|c|c|c|c|c|c|c|c|}
\hline \multirow{3}{*}{ Source } & \multirow{3}{*}{ Date } & \multirow{3}{*}{ Name } & \multirow{3}{*}{$\%$ Water } & \multirow{3}{*}{ pH } & \multirow{3}{*}{$\begin{array}{c}\text { Density } \\
(\mathrm{g} / \mathrm{ml})\end{array}$} & \multicolumn{4}{|c|}{ Glass Yield } \\
\hline & & & & & & \multirow{2}{*}{$(g / l)$} & Measured & Target & \multirow{2}{*}{ \%Dev. } \\
\hline & & & & & & & (kg/kg) & $(\mathrm{kg} / \mathbf{k g})$ & \\
\hline \multirow{2}{*}{$\begin{array}{c}\text { Stock } \\
\text { Feed }\end{array}$} & $5 / 21 / 13$ & F-10A-145C & 60.88 & 11.43 & 1.34 & 437 & 0.33 & 0.33 & -1.27 \\
\hline & $5 / 23 / 13$ & F-10A-145D & 60.93 & NA & NA & $\mathrm{NC}$ & 0.33 & 0.33 & -0.85 \\
\hline $\begin{array}{l}\text { Residual } \\
\text { Feed } \\
\text { from } \\
\text { Test } 2 \mathrm{E}\end{array}$ & $6 / 5 / 13$ & F-10B-81A & 59.04 & 11.19 & 1.33 & 452 & 0.34 & 0.33 & 3.03 \\
\hline
\end{tabular}

NA: Not analyzed

NC: Not calculated 
ORP-56310 Rev. 0

The Catholic University of America

Management of High Sulfur HLW

Vitreous State Laboratory

Final Report, VSL-13R2920-1, Rev. 0

Table 5.2. XRF Analyzed Compositions for the Vitrified Melter Feed Samples.

\begin{tabular}{|c|c|c|c|c|c|c|c|c|}
\hline \multirow[b]{2}{*}{ Constituents } & \multirow[b]{2}{*}{ Target } & \multicolumn{4}{|c|}{ Stock Feed Batch } & \multicolumn{3}{|c|}{ Residual feed from Test $\mathrm{E}$} \\
\hline & & $\begin{array}{l}\text { F-10A- } \\
145 \mathrm{C}-\mathrm{G}\end{array}$ & $\begin{array}{l}\text { F-10A- } \\
\text { 145D-G }\end{array}$ & Average & \% Dev. & Target & $\begin{array}{l}\text { F-10B- } \\
81 \mathrm{~A}-\mathrm{G}\end{array}$ & $\%$ Dev. \\
\hline $\mathrm{Al}_{2} \mathrm{O}_{3}$ & 8.19 & 6.52 & 6.53 & 6.52 & -20.35 & 8.14 & 7.86 & -3.44 \\
\hline $\mathrm{B}_{2} \mathrm{O}_{3} *$ & 9.70 & 10.05 & 10.03 & 10.04 & 3.51 & 9.63 & 10.30 & 6.92 \\
\hline $\mathrm{Bi}_{2} \mathrm{O}_{3}$ & 1.26 & 1.46 & 1.47 & 1.47 & 16.21 & 1.25 & 1.56 & 24.35 \\
\hline $\mathrm{CaO}$ & 8.34 & 8.87 & 8.72 & 8.80 & 5.43 & 8.29 & 8.83 & 6.61 \\
\hline $\mathrm{Cr}_{2} \mathrm{O}_{3}$ & 0.94 & 0.99 & 0.94 & 0.97 & $\mathrm{NC}$ & 0.93 & 1.02 & $\mathrm{NC}$ \\
\hline $\mathrm{F}^{\&}$ & 0.72 & 0.36 & 0.36 & $\mathrm{NC}$ & $\mathrm{NC}$ & 0.72 & 0.36 & $\mathrm{NC}$ \\
\hline $\mathrm{Fe}_{2} \mathrm{O}_{3}$ & 5.41 & 5.79 & 5.67 & 5.73 & 6.01 & 5.37 & 6.12 & 13.98 \\
\hline $\mathrm{K}_{2} \mathrm{O}$ & 0.28 & 0.28 & 0.28 & 0.28 & $\mathrm{NC}$ & 0.28 & 0.29 & $\mathrm{NC}$ \\
\hline $\mathrm{Li}_{2} \mathrm{O}^{*}$ & 2.50 & 2.60 & 2.66 & 2.63 & 5.20 & 2.48 & 2.59 & 4.31 \\
\hline $\mathrm{MgO}$ & 0.13 & 0.18 & 0.17 & 0.18 & $\mathrm{NC}$ & 0.13 & 0.17 & $\mathrm{NC}$ \\
\hline $\mathrm{MnO}$ & 4.52 & 4.08 & 4.10 & 4.09 & -9.48 & 4.49 & 3.59 & -20.01 \\
\hline $\mathrm{Na}_{2} \mathrm{O}$ & 12.45 & 12.53 & 12.55 & 12.54 & 0.75 & 12.36 & 11.95 & -3.36 \\
\hline $\mathrm{NiO}$ & 0.87 & 1.03 & 1.01 & 1.02 & $\mathrm{NC}$ & 0.86 & 1.04 & $\mathrm{NC}$ \\
\hline $\mathrm{P}_{2} \mathrm{O}_{5}$ & 1.56 & 1.60 & 1.55 & 1.57 & 0.77 & 1.55 & 1.52 & -2.14 \\
\hline $\mathrm{PbO}$ & 0.19 & 0.18 & 0.18 & 0.18 & $\mathrm{NC}$ & 0.19 & 0.20 & $\mathrm{NC}$ \\
\hline $\mathrm{SO}_{3}$ & 0.95 & 0.69 & 0.64 & 0.66 & $\mathrm{NC}$ & 1.63 & 0.94 & -42.25 \\
\hline $\mathrm{SiO}_{2}$ & 40.89 & 41.66 & 42.00 & 41.83 & 2.31 & 40.61 & 40.50 & -0.26 \\
\hline $\mathrm{SrO}$ & 1.03 & 1.04 & 1.03 & 1.04 & 1.11 & 1.02 & 1.07 & 4.68 \\
\hline $\mathrm{ZrO}_{2}$ & 0.07 & 0.09 & 0.09 & 0.09 & $\mathrm{NC}$ & 0.07 & 0.10 & $\mathrm{NC}$ \\
\hline Total & 100.00 & 100.00 & 100.00 & 100.00 & $\mathrm{NC}$ & 100.00 & 100.00 & $\mathrm{NC}$ \\
\hline
\end{tabular}

* - DCP-AES measured values

\& - Estimated as half target value; not analyzed by XRF

$\mathrm{NC}$ - Not calculated 
Table 5.3. List of Glass Discharged While Processing HLWS-27 Formulation.

\begin{tabular}{|c|c|c|c|c|}
\hline Test & Date & Name & Mass (kg) & $\begin{array}{c}\text { Cumulative Mass } \\
(\mathrm{kg})\end{array}$ \\
\hline \multirow{12}{*}{ A } & \multirow{9}{*}{$5 / 29 / 13$} & G-10B-22A & \multirow{2}{*}{2.62} & \multirow{2}{*}{2.62} \\
\hline & & G-10B-22B & & \\
\hline & & G-10B-22C & \multirow{2}{*}{2.74} & \multirow{2}{*}{5.36} \\
\hline & & G-10B-27A & & \\
\hline & & G-10B-27B & \multirow{2}{*}{3.44} & \multirow{2}{*}{8.80} \\
\hline & & G-10B-27C & & \\
\hline & & G-10B-28A & \multirow{2}{*}{3.06} & \multirow{2}{*}{11.86} \\
\hline & & G-10B-28B & & \\
\hline & & G-10B-28C & \multirow{2}{*}{3.40} & \multirow{2}{*}{15.26} \\
\hline & \multirow{11}{*}{$5 / 30 / 13$} & G-10B-29A & & \\
\hline & & G-10B-29B & \multirow{2}{*}{3.28} & \multirow{2}{*}{18.54} \\
\hline & & G-10B-29C & & \\
\hline \multirow{14}{*}{ B } & & G-10B-33A & \multirow{2}{*}{2.94} & \multirow{2}{*}{21.48} \\
\hline & & G-10B-33B & & \\
\hline & & G-10B-33C & \multirow{2}{*}{3.20} & \multirow{2}{*}{24.68} \\
\hline & & G-10B-37A & & \\
\hline & & G-10B-37B & \multirow{2}{*}{3.98} & \multirow{2}{*}{28.66} \\
\hline & & G-10B-40A & & \\
\hline & & G-10B-40B & \multirow{4}{*}{4.06} & \multirow{4}{*}{32.72} \\
\hline & & G-10B-40C & & \\
\hline & & G-10B-40D & & \\
\hline & & G-10B-40E & & \\
\hline & & G-10B-40F & \multirow{4}{*}{3.92} & \multirow{4}{*}{36.64} \\
\hline & & G-10B-41A & & \\
\hline & & G-10B-41B & & \\
\hline & & G-10B-41C & & \\
\hline \multirow{8}{*}{$\mathrm{C}$} & $5 / 2111$ & G-10B-46A & \multirow{4}{*}{3.48} & \multirow{4}{*}{40.12} \\
\hline & $5 / 31 / 13$ & G-10B-46B & & \\
\hline & & G-10B-46C & & \\
\hline & & G-10B-46D & & \\
\hline & & G-10B-46E & & \\
\hline & & G-10B-46F & 4.18 & 4430 \\
\hline & & G-10B-46G & 4.18 & \\
\hline & & G-10B-46H & & \\
\hline
\end{tabular}


ORP-56310 Rev. 0

The Catholic University of America

Management of High Sulfur HLW

Vitreous State Laboratory

Final Report, VSL-13R2920-1, Rev. 0

Table 5.3. List of Glass Discharged While Processing HLWS-27 Formulation (continued).

\begin{tabular}{|c|c|c|c|c|}
\hline Test & Date & Name & Mass (kg) & $\begin{array}{c}\text { Cumulative Mass } \\
\text { (kg) }\end{array}$ \\
\hline \multirow{12}{*}{$\mathrm{C}$} & \multirow{8}{*}{$5 / 31 / 13$} & G-10B-47A & \multirow{4}{*}{3.36} & \multirow{4}{*}{47.66} \\
\hline & & G-10B-47B & & \\
\hline & & G-10B-47C & & \\
\hline & & G-10B-47D & & \\
\hline & & G-10B-50A & \multirow{4}{*}{4.40} & \multirow{4}{*}{52.06} \\
\hline & & G-10B-50B & & \\
\hline & & G-10B-50C & & \\
\hline & & G-10B-50D & & \\
\hline & \multirow{4}{*}{$6 / 1 / 13$} & G-10B-50E & \multirow{4}{*}{3.16} & \multirow{4}{*}{55.22} \\
\hline & & G-10B-50F & & \\
\hline & & G-10B-50G & & \\
\hline & & G-10B-50H & & \\
\hline \multirow{17}{*}{$\mathrm{D}$} & \multirow{10}{*}{$6 / 3 / 13$} & G-10B-64A & \multirow{3}{*}{3.50} & \multirow{3}{*}{58.72} \\
\hline & & G-10B-64B & & \\
\hline & & G-10B-65A & & \\
\hline & & G-10B-65B & \multirow{3}{*}{2.44} & \multirow{3}{*}{61.16} \\
\hline & & G-10B-65C & & \\
\hline & & G-10B-65D & & \\
\hline & & G-10B-66A & \multirow{3}{*}{4.24} & \multirow{3}{*}{65.40} \\
\hline & & G-10B-66B & & \\
\hline & & G-10B-66C & & \\
\hline & & G-10B-66D & \multirow{3}{*}{2.84} & \multirow{3}{*}{68.24} \\
\hline & \multirow{11}{*}{$6 / 4 / 13$} & G-10B-67A & & \\
\hline & & G-10B-67B & & \\
\hline & & G-10B-67C & \multirow{4}{*}{4.18} & \multirow{4}{*}{72.42} \\
\hline & & G-10B-67D & & \\
\hline & & G-10B-67E & & \\
\hline & & G-10B-67F & & \\
\hline & & G-10B-72A & 0.86 & 73.28 \\
\hline \multirow{4}{*}{$\mathrm{E}$} & & G-10B-72B & \multirow{4}{*}{4.98} & \multirow{4}{*}{78.26} \\
\hline & & G-10B-73A & & \\
\hline & & G-10B-73B & & \\
\hline & & G-10B-73C & & \\
\hline
\end{tabular}


Table 5.3. List of Glass Discharged While Processing HLWS-27 Formulation (continued).

\begin{tabular}{|c|c|c|c|c|}
\hline Test & Date & Name & Mass (kg) & $\begin{array}{c}\text { Cumulative } \\
\text { Mass (kg) }\end{array}$ \\
\hline \multirow{11}{*}{$\mathrm{E}$} & \multirow{3}{*}{$6 / 4 / 13$} & G-10B-73D & \multirow{3}{*}{4.20} & \multirow{3}{*}{82.46} \\
\hline & & G-10B-73E & & \\
\hline & & G-10B-73F & & \\
\hline & \multirow{8}{*}{$6 / 5 / 13$} & G-10B-76A & \multirow{3}{*}{3.46} & \multirow{3}{*}{85.92} \\
\hline & & G-10B-76B & & \\
\hline & & G-10B-76C & & \\
\hline & & G-10B-76D & \multirow{3}{*}{3.68} & \multirow{3}{*}{89.60} \\
\hline & & G-10B-76E & & \\
\hline & & G-10B-76F & & \\
\hline & & G-10B-76G & \multirow{2}{*}{2.98} & \multirow{2}{*}{92.58} \\
\hline & & G-10B-81A & & \\
\hline
\end{tabular}


ORP-56310 Rev. 0

The Catholic University of America

Management of High Sulfur HLW

Vitreous State Laboratory

Final Report, VSL-13R2920-1, Rev. 0

Table 5.4. XRF Analyzed Compositions for Glass Discharged While Processing the HLWS-27 Formulation, Test A (wt\%).

\begin{tabular}{|c|c|c|c|c|c|c|c|c|}
\hline Mass (kg) & \multirow{2}{*}{ Target } & 2.62 & 5.36 & 8.80 & 11.86 & 15.26 & 18.54 & \multirow[b]{2}{*}{$\%$ Dev. } \\
\hline Constituents & & $\begin{array}{c}\text { G-10B- } \\
22 B \\
\end{array}$ & $\begin{array}{c}\text { G-10B- } \\
27 \mathrm{~A} \\
\end{array}$ & $\begin{array}{c}\text { G-10B- } \\
27 \mathrm{C} \\
\end{array}$ & $\begin{array}{c}\text { G-10B- } \\
28 \mathrm{~B} \\
\end{array}$ & $\begin{array}{c}\text { G-10B- } \\
29 \mathrm{~A} \\
\end{array}$ & $\begin{array}{c}\text { G-10B- } \\
29 \mathrm{C} \\
\end{array}$ & \\
\hline $\mathrm{Al}_{2} \mathrm{O}_{3}$ & 8.19 & 6.70 & 6.92 & 7.24 & 7.52 & 7.62 & 7.84 & -4.31 \\
\hline $\mathrm{B}_{2} \mathrm{O}_{3} *$ & 9.70 & $10.88^{\$}$ & 10.50 & 10.19 & 10.02 & 9.89 & 9.82 & $\mathrm{NC}$ \\
\hline $\mathrm{Bi}_{2} \mathrm{O}_{3}$ & 1.26 & 0.42 & 0.66 & 0.82 & 1.01 & 1.07 & 1.19 & -5.52 \\
\hline $\mathrm{CaO}$ & 8.34 & 3.26 & 4.46 & 5.50 & 6.45 & 6.84 & 7.40 & -11.31 \\
\hline $\mathrm{CdO}$ & $\&$ & 0.61 & 0.41 & 0.33 & 0.23 & 0.17 & 0.13 & $\mathrm{NC}$ \\
\hline $\mathrm{CeO}_{2}$ & $\&$ & 0.18 & 0.14 & 0.10 & 0.07 & 0.06 & $<0.01$ & $\mathrm{NC}$ \\
\hline $\mathrm{Cr}_{2} \mathrm{O}_{3}$ & 0.94 & 0.46 & 0.58 & 0.70 & 0.71 & 0.69 & 0.77 & $\mathrm{NC}$ \\
\hline $\mathrm{Cs}_{2} \mathrm{O}$ & $\&$ & 0.08 & 0.05 & $<0.01$ & $<0.01$ & $<0.01$ & $<0.01$ & $\mathrm{NC}$ \\
\hline $\mathrm{F}$ & 0.72 & $0.14^{\#}$ & 0.17 & 0.20 & 0.23 & 0.26 & $0.29^{\#}$ & $\mathrm{NC}$ \\
\hline $\mathrm{Fe}_{2} \mathrm{O}_{3}$ & 5.41 & 9.71 & 8.67 & 7.76 & 6.85 & 6.51 & 6.39 & 18.23 \\
\hline $\mathrm{K}_{2} \mathrm{O}$ & 0.28 & 0.19 & 0.33 & 0.33 & 0.36 & 0.20 & 0.34 & $\mathrm{NC}$ \\
\hline $\mathrm{La}_{2} \mathrm{O}_{3}$ & $\&$ & 0.10 & 0.08 & 0.05 & 0.03 & 0.05 & 0.03 & $\mathrm{NC}$ \\
\hline $\mathrm{Li}_{2} \mathrm{O}^{*}$ & 2.50 & $3.78^{\S}$ & 3.37 & 3.03 & 2.84 & 2.71 & 2.63 & $\mathrm{NC}$ \\
\hline $\mathrm{MgO}$ & 0.13 & 0.18 & 0.19 & 0.20 & 0.17 & 0.16 & 0.18 & $\mathrm{NC}$ \\
\hline $\mathrm{MnO}$ & 4.52 & 1.18 & 2.13 & 2.80 & 3.24 & 3.51 & 3.50 & -22.61 \\
\hline $\mathrm{Na}_{2} \mathrm{O}$ & 12.45 & 11.65 & 11.91 & 12.00 & 11.97 & 12.21 & 12.38 & -0.53 \\
\hline $\mathrm{Nd}_{2} \mathrm{O}_{3}$ & $\&$ & 0.14 & 0.11 & 0.10 & 0.06 & $<0.01$ & 0.04 & $\mathrm{NC}$ \\
\hline $\mathrm{NiO}$ & 0.87 & 0.98 & 0.95 & 0.96 & 0.98 & 0.97 & 1.01 & $\mathrm{NC}$ \\
\hline $\mathrm{P}_{2} \mathrm{O}_{5}$ & 1.56 & 0.77 & 0.95 & 1.09 & 1.28 & 1.36 & 1.38 & -11.61 \\
\hline $\mathrm{PbO}$ & 0.19 & 0.05 & 0.08 & 0.10 & 0.13 & 0.13 & 0.15 & $\mathrm{NC}$ \\
\hline $\mathrm{SO}_{3}$ & 0.93 & 0.37 & 0.49 & 0.59 & 0.65 & 0.65 & 0.71 & $\mathrm{NC}$ \\
\hline $\mathrm{SiO}_{2}$ & 40.89 & 43.65 & 43.22 & 42.90 & 42.84 & 42.80 & 41.92 & 2.52 \\
\hline $\mathrm{SnO}_{2}$ & $\&$ & 0.13 & 0.10 & 0.07 & 0.05 & 0.06 & 0.03 & $\mathrm{NC}$ \\
\hline $\mathrm{SrO}$ & 1.03 & 0.28 & 0.46 & 0.58 & 0.69 & 0.76 & 0.84 & -18.57 \\
\hline $\mathrm{TiO}_{2}$ & $\&$ & 0.07 & 0.07 & 0.05 & 0.04 & 0.04 & 0.02 & $\mathrm{NC}$ \\
\hline $\mathrm{ZnO}$ & $\&$ & 1.56 & 1.14 & 0.86 & 0.58 & 0.45 & 0.35 & $\mathrm{NC}$ \\
\hline $\mathrm{ZrO}_{2}$ & 0.07 & 2.50 & 1.87 & 1.47 & 1.01 & 0.82 & 0.66 & $\mathrm{NC}$ \\
\hline Sum & 100.00 & 100.00 & 100.00 & 100.00 & 100.00 & 100.00 & 100.00 & $\mathrm{NC}$ \\
\hline
\end{tabular}

* Values calculated from $\mathrm{B}_{2} \mathrm{O}_{3}$ and $\mathrm{Li}_{2} \mathrm{O}$ analysis by DCP-AES on the first discharged glass sample and feed sample using a simple well stirred tank model.

$\$$ - DCP-AES results

$\&$ - Not a target constituent

\# - F was measured by XRF, values for other samples calculated by linear interpolation. 
ORP-56310 Rev. 0

The Catholic University of America

Management of High Sulfur HLW

Vitreous State Laboratory

Final Report, VSL-13R2920-1, Rev. 0

Table 5.5. XRF Analyzed Compositions for Glass Discharged While Processing the HLWS-27 Formulation, Test B (wt\%).

\begin{tabular}{|c|c|c|c|c|c|c|c|}
\hline Mass (kg) & \multirow{2}{*}{ Target } & 21.48 & 24.68 & 28.66 & 32.72 & 36.64 & \multirow[b]{2}{*}{$\%$ Dev. } \\
\hline Constituents & & $\begin{array}{c}\text { G-10B- } \\
33 \mathrm{~B} \\
\end{array}$ & $\begin{array}{c}\text { G-10B- } \\
37 \mathrm{~A}\end{array}$ & $\begin{array}{c}\text { G-10B- } \\
40 \mathrm{~A} \\
\end{array}$ & G-10B-40E & $\begin{array}{c}\text { G-10B- } \\
41 \mathrm{C} \\
\end{array}$ & \\
\hline $\mathrm{Al}_{2} \mathrm{O}_{3}$ & 8.16 & 7.86 & 7.86 & 7.87 & 7.96 & 7.89 & -3.40 \\
\hline $\mathrm{B}_{2} \mathrm{O}_{3} *$ & 9.67 & 9.78 & 9.75 & 9.73 & 9.72 & 9.71 & $\mathrm{NC}$ \\
\hline $\mathrm{Bi}_{2} \mathrm{O}_{3}$ & 1.26 & 1.22 & 1.29 & 1.31 & 1.33 & 1.38 & 9.36 \\
\hline $\mathrm{CaO}$ & 8.31 & 7.66 & 7.88 & 8.01 & 8.22 & 8.40 & 1.04 \\
\hline $\mathrm{CdO}$ & $\&$ & 0.09 & 0.07 & 0.05 & 0.03 & 0.02 & $\mathrm{NC}$ \\
\hline $\mathrm{CeO}_{2}$ & $\&$ & 0.03 & $<0.01$ & 0.04 & $<0.01$ & $<0.01$ & $\mathrm{NC}$ \\
\hline $\mathrm{Cr}_{2} \mathrm{O}_{3}$ & 0.94 & 0.78 & 0.78 & 0.78 & 0.82 & 0.82 & $\mathrm{NC}$ \\
\hline $\mathrm{Cs}_{2} \mathrm{O}$ & $\&$ & $<0.01$ & $<0.01$ & $<0.01$ & $<0.01$ & $<0.01$ & $\mathrm{NC}$ \\
\hline $\mathrm{F}$ & 0.72 & $0.26^{\#}$ & 0.26 & 0.26 & 0.26 & $0.26^{\#}$ & $\mathrm{NC}$ \\
\hline $\mathrm{Fe}_{2} \mathrm{O}_{3}$ & 5.39 & 5.98 & 6.07 & 5.67 & 5.59 & 5.69 & 5.63 \\
\hline $\mathrm{K}_{2} \mathrm{O}$ & 0.28 & 0.33 & 0.23 & 0.23 & 0.23 & 0.25 & $\mathrm{NC}$ \\
\hline $\mathrm{La}_{2} \mathrm{O}_{3}$ & $\&$ & 0.04 & $<0.01$ & 0.04 & $<0.01$ & $<0.01$ & $\mathrm{NC}$ \\
\hline $\mathrm{Li}_{2} \mathrm{O}^{*}$ & 2.49 & 2.59 & 2.55 & 2.53 & 2.52 & 2.51 & $\mathrm{NC}$ \\
\hline $\mathrm{MgO}$ & 0.13 & 0.17 & 0.18 & 0.15 & 0.17 & 0.20 & $\mathrm{NC}$ \\
\hline $\mathrm{MnO}$ & 4.51 & 3.47 & 3.76 & 4.22 & 4.41 & 4.12 & -8.55 \\
\hline $\mathrm{Na}_{2} \mathrm{O}$ & 12.40 & 12.81 & 12.54 & 12.62 & 12.21 & 12.61 & 1.66 \\
\hline $\mathrm{Nd}_{2} \mathrm{O}_{3}$ & $\&$ & 0.04 & $<0.01$ & $<0.01$ & $<0.01$ & $<0.01$ & $\mathrm{NC}$ \\
\hline $\mathrm{NiO}$ & 0.86 & 0.97 & 1.00 & 1.00 & 0.98 & 0.95 & $\mathrm{NC}$ \\
\hline $\mathrm{P}_{2} \mathrm{O}_{5}$ & 1.55 & 1.45 & 1.47 & 1.45 & 1.55 & 1.49 & -4.29 \\
\hline $\mathrm{PbO}$ & 0.19 & 0.16 & 0.16 & 0.16 & 0.16 & 0.18 & $\mathrm{NC}$ \\
\hline $\mathrm{SO}_{3}$ & 1.30 & 0.76 & 0.81 & 0.89 & 0.93 & 0.94 & -27.93 \\
\hline $\mathrm{SiO}_{2}$ & 40.74 & 41.84 & 41.75 & 41.52 & 41.54 & 41.22 & 1.18 \\
\hline $\mathrm{SnO}_{2}$ & $\&$ & 0.02 & $<0.01$ & $<0.01$ & $<0.01$ & $<0.01$ & $\mathrm{NC}$ \\
\hline $\mathrm{SrO}$ & 1.02 & 0.86 & 0.91 & 0.93 & 0.94 & 0.97 & -5.50 \\
\hline $\mathrm{TiO}_{2}$ & $\&$ & 0.02 & $<0.01$ & 0.02 & 0.02 & 0.03 & $\mathrm{NC}$ \\
\hline $\mathrm{ZnO}$ & $\&$ & 0.27 & 0.22 & 0.15 & 0.11 & 0.08 & $\mathrm{NC}$ \\
\hline $\mathrm{ZrO}_{2}$ & 0.07 & 0.53 & 0.45 & 0.37 & 0.32 & 0.29 & $\mathrm{NC}$ \\
\hline Sum & 100.00 & 100.00 & 100.00 & 100.00 & 100.00 & 100.00 & $\mathrm{NC}$ \\
\hline
\end{tabular}

* Values calculated from $\mathrm{B}_{2} \mathrm{O}_{3}$ and $\mathrm{Li}_{2} \mathrm{O}$ analysis by DCP-AES on the first discharged glass sample and feed sample using a simple well stirred tank model.

\& - Not a target constituent

\# - F was measured by XRF, values for other samples calculated by interpolation 
ORP-56310 Rev. 0

The Catholic University of America

Management of High Sulfur HLW

Vitreous State Laboratory

Final Report, VSL-13R2920-1, Rev. 0

Table 5.6. XRF Analyzed Compositions for Glass Discharged While Processing the HLWS-27 Formulation, Test C (wt\%).

\begin{tabular}{|c|c|c|c|c|c|c|c|}
\hline Mass (kg) & \multirow{2}{*}{ Target } & 40.12 & 44.30 & 47.66 & 52.06 & 55.22 & \multirow{2}{*}{$\%$ Dev. } \\
\hline Constituents & & G-10B-46D & $\begin{array}{c}\text { G-10B- } \\
46 \mathrm{H} \\
\end{array}$ & $\begin{array}{c}\text { G-10B- } \\
47 \mathrm{D}\end{array}$ & $\begin{array}{c}\text { G-10B- } \\
50 \mathrm{D}\end{array}$ & $\begin{array}{c}\text { G-10B- } \\
50 \mathrm{H} \\
\end{array}$ & \\
\hline $\mathrm{Al}_{2} \mathrm{O}_{3}$ & 8.15 & 7.89 & 7.81 & 7.87 & 8.15 & 7.95 & -2.43 \\
\hline $\mathrm{B}_{2} \mathrm{O}_{3} *$ & 9.65 & 9.71 & 9.70 & 9.70 & 9.70 & 9.70 & $\mathrm{NC}$ \\
\hline $\mathrm{Bi}_{2} \mathrm{O}_{3}$ & 1.26 & 1.40 & 1.43 & 1.41 & 1.29 & 1.35 & 7.35 \\
\hline $\mathrm{CaO}$ & 8.30 & 8.50 & 8.36 & 8.43 & 8.28 & 8.51 & 2.56 \\
\hline $\mathrm{CdO}$ & $\&$ & 0.02 & 0.01 & 0.01 & 0.01 & $<0.01$ & $\mathrm{NC}$ \\
\hline $\mathrm{CeO}_{2}$ & $\&$ & $<0.01$ & $<0.01$ & $<0.01$ & $<0.01$ & $<0.01$ & $\mathrm{NC}$ \\
\hline $\mathrm{Cr}_{2} \mathrm{O}_{3}$ & 0.93 & 0.79 & 0.84 & 0.84 & 0.84 & 0.87 & $\mathrm{NC}$ \\
\hline $\mathrm{Cs}_{2} \mathrm{O}$ & $\&$ & $<0.01$ & $<0.01$ & $<0.01$ & $<0.01$ & $<0.01$ & $\mathrm{NC}$ \\
\hline $\mathrm{F}$ & 0.72 & $0.27^{\#}$ & 0.27 & 0.27 & 0.27 & $0.27^{\#}$ & $\mathrm{NC}$ \\
\hline $\mathrm{Fe}_{2} \mathrm{O}_{3}$ & 5.38 & 5.83 & 5.60 & 5.48 & 5.34 & 5.37 & -0.09 \\
\hline $\mathrm{K}_{2} \mathrm{O}$ & 0.28 & 0.28 & 0.21 & 0.30 & 0.19 & 0.27 & $\mathrm{NC}$ \\
\hline $\mathrm{La}_{2} \mathrm{O}_{3}$ & $\&$ & $<0.01$ & $<0.01$ & $<0.01$ & $<0.01$ & $<0.01$ & $\mathrm{NC}$ \\
\hline $\mathrm{Li}_{2} \mathrm{O}^{*}$ & 2.49 & 2.51 & 2.50 & 2.50 & 2.50 & 2.50 & $\mathrm{NC}$ \\
\hline $\mathrm{MgO}$ & 0.13 & 0.16 & 0.18 & 0.15 & 0.17 & 0.18 & $\mathrm{NC}$ \\
\hline $\mathrm{MnO}$ & 4.50 & 4.66 & 4.73 & 4.68 & 4.38 & 4.15 & -7.73 \\
\hline $\mathrm{Na}_{2} \mathrm{O}$ & 12.38 & 12.15 & 12.73 & 12.46 & 12.55 & 12.45 & 0.57 \\
\hline $\mathrm{Nd}_{2} \mathrm{O}_{3}$ & $\&$ & $<0.01$ & $<0.01$ & $<0.01$ & $<0.01$ & $<0.01$ & $\mathrm{NC}$ \\
\hline $\mathrm{NiO}$ & 0.86 & 1.00 & 0.96 & 0.96 & 0.94 & 0.93 & $\mathrm{NC}$ \\
\hline $\mathrm{P}_{2} \mathrm{O}_{5}$ & 1.55 & 1.48 & 1.51 & 1.50 & 1.52 & 1.53 & -1.49 \\
\hline $\mathrm{PbO}$ & 0.19 & 0.19 & 0.17 & 0.18 & 0.15 & 0.16 & $\mathrm{NC}$ \\
\hline $\mathrm{SO}_{3}$ & 1.50 & 0.99 & 0.99 & 0.95 & 1.00 & 1.04 & -30.69 \\
\hline $\mathrm{SiO}_{2}$ & 40.66 & 40.78 & 40.64 & 41.00 & 41.62 & 41.51 & 2.09 \\
\hline $\mathrm{SnO}_{2}$ & $\&$ & $<0.01$ & $<0.01$ & $<0.01$ & $<0.01$ & $<0.01$ & $\mathrm{NC}$ \\
\hline $\mathrm{SrO}$ & 1.02 & 1.01 & 1.01 & 0.97 & 0.93 & 0.98 & -4.41 \\
\hline $\mathrm{TiO}_{2}$ & $\&$ & 0.02 & 0.02 & 0.02 & 0.02 & $<0.01$ & $\mathrm{NC}$ \\
\hline $\mathrm{ZnO}$ & $\&$ & 0.07 & 0.05 & 0.05 & 0.04 & 0.03 & $\mathrm{NC}$ \\
\hline $\mathrm{ZrO}_{2}$ & 0.07 & 0.29 & 0.27 & 0.26 & 0.10 & 0.25 & $\mathrm{NC}$ \\
\hline Sum & 100.00 & 100.00 & 100.00 & 100.00 & 100.00 & 100.00 & $\mathrm{NC}$ \\
\hline
\end{tabular}

* Values calculated from $\mathrm{B}_{2} \mathrm{O}_{3}$ and $\mathrm{Li}_{2} \mathrm{O}$ analysis by DCP-AES on the first discharged glass sample and feed sample using a simple well stirred tank model.

$\&$ - Not a target constituent

\# - F was measured by XRF, values for other samples calculated by interpolation 
ORP-56310 Rev. 0

The Catholic University of America

Management of High Sulfur HLW

Vitreous State Laboratory

Final Report, VSL-13R2920-1, Rev. 0

Table 5.7. XRF Analyzed Compositions for Glass Discharged While Processing the HLWS-27 Formulation, Test D (wt\%).

\begin{tabular}{|c|c|c|c|c|c|c|c|c|}
\hline Mass (kg) & \multirow{2}{*}{ Target } & 58.72 & 61.16 & 65.40 & 68.24 & 72.42 & 73.28 & \multirow{2}{*}{ \% Dev. } \\
\hline Constituents & & G-10B-65A & G-10B-65D & $\begin{array}{c}\text { G-10B- } \\
66 \mathrm{C}\end{array}$ & $\begin{array}{c}\text { G-10B- } \\
67 \mathrm{~B}\end{array}$ & $\begin{array}{c}\text { G-10B- } \\
67 \mathrm{~F}\end{array}$ & $\begin{array}{c}\text { G-10B- } \\
72 \mathrm{~A}\end{array}$ & \\
\hline $\mathrm{Al}_{2} \mathrm{O}_{3}$ & 8.12 & 7.97 & 8.01 & 8.07 & 7.92 & 8.06 & 8.01 & -1.41 \\
\hline $\mathrm{B}_{2} \mathrm{O}_{3} *$ & 9.62 & 9.70 & 9.70 & 9.70 & 9.70 & 9.70 & 9.70 & $\mathrm{NC}$ \\
\hline $\mathrm{Bi}_{2} \mathrm{O}_{3}$ & 1.25 & 1.41 & 1.44 & 1.34 & 1.36 & 1.39 & 1.35 & 10.29 \\
\hline $\mathrm{CaO}$ & 8.27 & 8.57 & 8.44 & 8.32 & 8.35 & 8.32 & 8.37 & 1.12 \\
\hline $\mathrm{CdO}$ & $\&$ & 0.01 & 0.01 & $<0.01$ & $<0.01$ & $<0.01$ & $<0.01$ & $\mathrm{NC}$ \\
\hline $\mathrm{CeO}_{2}$ & $\&$ & $<0.01$ & $<0.01$ & $<0.01$ & $<0.01$ & $<0.01$ & $<0.01$ & $\mathrm{NC}$ \\
\hline $\mathrm{Cr}_{2} \mathrm{O}_{3}$ & 0.93 & 0.77 & 0.81 & 0.86 & 0.80 & 0.82 & 0.77 & $\mathrm{NC}$ \\
\hline $\mathrm{Cs}_{2} \mathrm{O}$ & $\&$ & $<0.01$ & $<0.01$ & $<0.01$ & $<0.01$ & $<0.01$ & $<0.01$ & $\mathrm{NC}$ \\
\hline $\mathrm{F}$ & 0.72 & $0.18^{\#}$ & 0.21 & 0.26 & 0.29 & $0.34^{\#}$ & 0.34 & $\mathrm{NC}$ \\
\hline $\mathrm{Fe}_{2} \mathrm{O}_{3}$ & 5.36 & 5.54 & 5.54 & 5.33 & 5.32 & 5.38 & 5.28 & -1.58 \\
\hline $\mathrm{K}_{2} \mathrm{O}$ & 0.28 & 0.30 & 0.18 & 0.26 & 0.29 & 0.28 & 0.28 & $\mathrm{NC}$ \\
\hline $\mathrm{La}_{2} \mathrm{O}_{3}$ & $\&$ & $<0.01$ & $<0.01$ & $<0.01$ & $<0.01$ & $<0.01$ & $<0.01$ & $\mathrm{NC}$ \\
\hline $\mathrm{Li}_{2} \mathrm{O}^{*}$ & 2.48 & 2.50 & 2.50 & 2.50 & 2.50 & 2.50 & 2.50 & $\mathrm{NC}$ \\
\hline $\mathrm{MgO}$ & 0.13 & 0.17 & 0.17 & 0.17 & 0.17 & 0.16 & 0.14 & $\mathrm{NC}$ \\
\hline $\mathrm{MnO}$ & 4.48 & 4.28 & 4.40 & 4.39 & 4.54 & 4.53 & 4.45 & -0.73 \\
\hline $\mathrm{Na}_{2} \mathrm{O}$ & 12.34 & 12.38 & 12.77 & 12.39 & 12.58 & 12.49 & 12.39 & 0.35 \\
\hline $\mathrm{Nd}_{2} \mathrm{O}_{3}$ & $\&$ & $<0.01$ & $<0.01$ & $<0.01$ & $<0.01$ & $<0.01$ & $<0.01$ & $\mathrm{NC}$ \\
\hline $\mathrm{NiO}$ & 0.86 & 0.93 & 0.94 & 0.91 & 0.90 & 0.93 & 0.89 & $\mathrm{NC}$ \\
\hline $\mathrm{P}_{2} \mathrm{O}_{5}$ & 1.55 & 1.52 & 1.46 & 1.53 & 1.51 & 1.46 & 1.54 & -0.51 \\
\hline $\mathrm{PbO}$ & 0.19 & 0.17 & 0.17 & 0.17 & 0.17 & 0.16 & 0.17 & $\mathrm{NC}$ \\
\hline $\mathrm{SO}_{3}$ & 1.78 & 1.05 & 1.07 & 1.22 & 1.24 & 1.28 & 1.23 & -30.69 \\
\hline $\mathrm{SiO}_{2}$ & 40.54 & 41.15 & 40.87 & 41.30 & 41.12 & 40.93 & 41.36 & 2.02 \\
\hline $\mathrm{SnO}_{2}$ & $\&$ & $<0.01$ & $<0.01$ & $<0.01$ & $<0.01$ & $<0.01$ & $<0.01$ & $\mathrm{NC}$ \\
\hline $\mathrm{SrO}$ & 1.02 & 1.01 & 1.00 & 0.97 & 0.95 & 0.97 & 0.93 & -8.26 \\
\hline $\mathrm{TiO}_{2}$ & $\&$ & 0.02 & 0.02 & 0.02 & 0.02 & 0.02 & 0.02 & $\mathrm{NC}$ \\
\hline $\mathrm{ZnO}$ & $\&$ & 0.08 & 0.06 & 0.04 & 0.04 & 0.03 & 0.03 & $\mathrm{NC}$ \\
\hline $\mathrm{ZrO}_{2}$ & 0.07 & 0.28 & 0.26 & 0.26 & 0.25 & 0.25 & 0.25 & $\mathrm{NC}$ \\
\hline Sum & 100.00 & 100.00 & 100.00 & 100.00 & 100.00 & 100.00 & 100.00 & $\mathrm{NC}$ \\
\hline
\end{tabular}

* Values calculated from $\mathrm{B}_{2} \mathrm{O}_{3}$ and $\mathrm{Li}_{2} \mathrm{O}$ analysis by DCP-AES on the first discharged glass sample and feed sample using a simple well stirred tank model.

$\&$ - Not a target constituent

\# - F was measured by XRF, values for other samples calculated by interpolation 
Table 5.8. XRF Analyzed Compositions for Glass Discharged While Processing the HLWS-27 Formulation, Test E (wt\%).

\begin{tabular}{|c|c|c|c|c|c|c|c|}
\hline Mass (kg) & \multirow{2}{*}{ Target } & 78.26 & 82.46 & 85.92 & 89.60 & 92.58 & \multirow{2}{*}{$\%$ Dev. } \\
\hline Constituents & & G-10B-73C & G-10B-73F & G-10B-76C & G-10B-76F & G-10B-81A & \\
\hline $\mathrm{Al}_{2} \mathrm{O}_{3}$ & 8.14 & 7.96 & 7.99 & 8.10 & 7.97 & 7.96 & -2.20 \\
\hline $\mathrm{B}_{2} \mathrm{O}_{3}{ }^{*}$ & 9.63 & 9.70 & 9.70 & 9.70 & 9.70 & 9.70 & $\mathrm{NC}$ \\
\hline $\mathrm{Bi}_{2} \mathrm{O}_{3}$ & 1.25 & 1.43 & 1.34 & 1.36 & 1.40 & 1.47 & 17.47 \\
\hline $\mathrm{CaO}$ & 8.29 & 8.66 & 8.47 & 8.46 & 8.61 & 8.61 & 3.90 \\
\hline $\mathrm{CdO}$ & $\&$ & $<0.01$ & $<0.01$ & $<0.01$ & $<0.01$ & $<0.01$ & $\mathrm{NC}$ \\
\hline $\mathrm{CeO}_{2}$ & $\&$ & $<0.01$ & $<0.01$ & $<0.01$ & $<0.01$ & $<0.01$ & $\mathrm{NC}$ \\
\hline $\mathrm{Cr}_{2} \mathrm{O}_{3}$ & 0.93 & 0.81 & 0.82 & 0.79 & 0.85 & 0.84 & $\mathrm{NC}$ \\
\hline $\mathrm{Cs}_{2} \mathrm{O}$ & $\&$ & $<0.01$ & $<0.01$ & $<0.01$ & $<0.01$ & $<0.01$ & $\mathrm{NC}$ \\
\hline F & 0.72 & $0.22^{\#}$ & 0.24 & 0.24 & 0.26 & $0.26^{\#}$ & $\mathrm{NC}$ \\
\hline $\mathrm{Fe}_{2} \mathrm{O}_{3}$ & 5.37 & 5.60 & 5.40 & 5.47 & 5.56 & 5.70 & 6.24 \\
\hline $\mathrm{K}_{2} \mathrm{O}$ & 0.28 & 0.28 & 0.26 & 0.28 & 0.27 & 0.29 & $\mathrm{NC}$ \\
\hline $\mathrm{La}_{2} \mathrm{O}_{3}$ & $\&$ & $<0.01$ & $<0.01$ & $<0.01$ & $<0.01$ & $<0.01$ & $\mathrm{NC}$ \\
\hline $\mathrm{Li}_{2} \mathrm{O}^{*}$ & 2.48 & 2.50 & 2.50 & 2.50 & 2.50 & 2.50 & $\mathrm{NC}$ \\
\hline $\mathrm{MgO}$ & 0.13 & 0.17 & 0.17 & 0.20 & 0.16 & 0.15 & $\mathrm{NC}$ \\
\hline $\mathrm{MnO}$ & 4.49 & 4.06 & 4.29 & 4.17 & 4.14 & 4.29 & -4.54 \\
\hline $\mathrm{Na}_{2} \mathrm{O}$ & 12.36 & 12.37 & 12.52 & 12.78 & 12.54 & 12.26 & -0.84 \\
\hline $\mathrm{Nd}_{2} \mathrm{O}_{3}$ & $\&$ & $<0.01$ & $<0.01$ & $<0.01$ & $<0.01$ & $<0.01$ & $\mathrm{NC}$ \\
\hline $\mathrm{NiO}$ & 0.86 & 0.98 & 0.95 & 0.94 & 0.97 & 0.94 & $\mathrm{NC}$ \\
\hline $\mathrm{P}_{2} \mathrm{O}_{5}$ & 1.55 & 1.54 & 1.49 & 1.50 & 1.52 & 1.50 & -2.96 \\
\hline $\mathrm{PbO}$ & 0.19 & 0.17 & 0.17 & 0.17 & 0.18 & 0.18 & $\mathrm{NC}$ \\
\hline $\mathrm{SO}_{3}$ & 1.63 & 1.06 & 1.17 & 1.12 & 1.09 & 1.13 & -30.96 \\
\hline $\mathrm{SiO}_{2}$ & 40.61 & 41.31 & 41.26 & 40.95 & 40.99 & 41.00 & 0.97 \\
\hline $\mathrm{SnO}_{2}$ & $\&$ & $<0.01$ & $<0.01$ & $<0.01$ & $<0.01$ & $<0.01$ & $\mathrm{NC}$ \\
\hline $\mathrm{SrO}$ & 1.02 & 1.01 & 0.98 & 0.98 & 0.99 & 1.01 & -0.61 \\
\hline $\mathrm{TiO}_{2}$ & $\&$ & 0.03 & 0.03 & 0.02 & 0.02 & 0.02 & $\mathrm{NC}$ \\
\hline $\mathrm{ZnO}$ & $\&$ & 0.03 & 0.02 & 0.02 & 0.02 & 0.02 & $\mathrm{NC}$ \\
\hline $\mathrm{ZrO}_{2}$ & 0.07 & 0.10 & 0.25 & 0.24 & 0.26 & 0.17 & $\mathrm{NC}$ \\
\hline Sum & 100.00 & 100.00 & 100.00 & 100.00 & 100.00 & 100.00 & $\mathrm{NC}$ \\
\hline
\end{tabular}

* Values calculated from $\mathrm{B}_{2} \mathrm{O}_{3}$ and $\mathrm{Li}_{2} \mathrm{O}$ analysis by DCP-AES on the first discharged glass sample and feed sample using a simple well stirred tank model.

$\&$ - Not a target constituent

\# - F was measured by XRF, values for other samples calculated by interpolation 
ORP-56310 Rev. 0

The Catholic University of America

Management of High Sulfur HLW

Vitreous State Laboratory

Final Report, VSL-13R2920-1, Rev. 0

Table 5.9. List of Glass Pool Samples Taken While Processing HLWS-27 Formulation.

\begin{tabular}{|c|c|c|c|c|c|c|}
\hline Test & Date & Time & Sample ID & Location & $\begin{array}{c}\text { Secondary Phases } \\
\text { Observed }\end{array}$ & $\begin{array}{c}\text { Depth of Glass } \\
\text { Pool (inches) } \\
\end{array}$ \\
\hline \multirow{3}{*}{ Before A } & \multirow{3}{*}{$5 / 29 / 2013$} & \multirow{3}{*}{$9: 17$} & D-10B-22A & North West & No & 6.75 \\
\hline & & & D-10B-22B & Center & No & 6.75 \\
\hline & & & D-10B-22C & South East & No & 6.75 \\
\hline \multirow{3}{*}{ After A } & \multirow{3}{*}{$5 / 30 / 2013$} & \multirow{3}{*}{$5: 45$} & D-10B-33A & North West & No & 6.75 \\
\hline & & & D-10B-33B & Center & No & 6.75 \\
\hline & & & D-10B-33C & South East & No & 6.75 \\
\hline \multirow{3}{*}{ After B } & \multirow{3}{*}{$5 / 31 / 2013$} & $7: 35$ & D-10B-41A & North West & No & 6.75 \\
\hline & & $7: 40$ & D-10B-41B & Center & No & 6.75 \\
\hline & & $7: 43$ & D-10B-41C & South East & No & 6.75 \\
\hline \multirow{3}{*}{ After C } & \multirow{3}{*}{$6 / 01 / 2013$} & \multirow{3}{*}{$3: 45$} & D-10B-53A & North West & No & 6.50 \\
\hline & & & D-10B-53B & Center & No & 6.50 \\
\hline & & & D-10B-53C & South East & No & 6.50 \\
\hline \multirow{4}{*}{ Before D } & \multirow{4}{*}{$6 / 03 / 2013$} & \multirow{3}{*}{$7: 50$} & D-10B-53D & North West & No & 6.50 \\
\hline & & & D-10B-53E & Center & No & 6.50 \\
\hline & & & D-10B-53F & South East & Yes & 6.50 \\
\hline & & $9: 32$ & D-10B-64A & South East & No & 6.50 \\
\hline \multirow{3}{*}{ After D } & \multirow{4}{*}{$6 / 04 / 2013$} & \multirow{3}{*}{$6: 17$} & D-10B-67A & North West & Yes & 7.00 \\
\hline & & & D-10B-67B & Center & No & 7.00 \\
\hline & & & D-10B-67C & South East & Yes & 7.00 \\
\hline Before E & & $12: 30$ & D-10B-72A & South East & No & 6.25 \\
\hline \multirow{3}{*}{ After E } & \multirow{3}{*}{$6 / 05 / 2013$} & \multirow{3}{*}{$11: 30$} & D-10B-81A & North West & No & 6.50 \\
\hline & & & D-10B-81B & Center & No & 6.50 \\
\hline & & & D-10B-81C & South East & No & 6.50 \\
\hline
\end{tabular}


ORP-56310 Rev. 0

The Catholic University of America

Management of High Sulfur HLW

Vitreous State Laboratory

Final Report, VSL-13R2920-1, Rev. 0

Table 5.10. XRF Analyzed Compositions for the Dip Samples Taken While Processing the HLWS-27 Formulation.

\begin{tabular}{|c|c|c|c|c|c|c|c|c|c|c|c|}
\hline Test & $\begin{array}{l}\text { Before } \\
\text { Test A }\end{array}$ & After & Test A & After & Test B & After & Test C & After & Test D & After & Test E \\
\hline Constituent & $\begin{array}{c}\text { D-10B- } \\
22 \mathrm{~A}\end{array}$ & Target & $\begin{array}{c}\mathrm{D}- \\
10 \mathrm{~B}- \\
33 \mathrm{~A}\end{array}$ & Target & $\begin{array}{c}\text { D- } \\
\text { 10B- } \\
41 \mathrm{~A}\end{array}$ & Target & $\begin{array}{c}\mathrm{D}- \\
10 \mathrm{~B}- \\
53 \mathrm{C}\end{array}$ & Target & $\begin{array}{c}\text { D- } \\
\text { 10B- } \\
72 \mathrm{~A}\end{array}$ & Target & $\begin{array}{c}\mathrm{D}- \\
\text { 10B- } \\
81 \mathrm{~B}\end{array}$ \\
\hline $\mathrm{Al}_{2} \mathrm{O}_{3}$ & 6.43 & 8.19 & 7.75 & 8.16 & 7.86 & 8.15 & 8.06 & 8.12 & 7.89 & 8.14 & 8.06 \\
\hline $\mathrm{B}_{2} \mathrm{O}_{3}{ }^{*}$ & 10.88 & 9.70 & 9.82 & 9.67 & 9.71 & 9.65 & 9.70 & 9.62 & 9.70 & 9.63 & 9.70 \\
\hline $\mathrm{Bi}_{2} \mathrm{O}_{3}$ & 0.19 & 1.26 & 1.24 & 1.26 & 1.41 & 1.26 & 1.39 & 1.25 & 1.45 & 1.25 & 1.41 \\
\hline $\mathrm{CaO}$ & 2.14 & 8.34 & 7.66 & 8.31 & 8.48 & 8.30 & 8.50 & 8.27 & 8.51 & 8.29 & 8.50 \\
\hline $\mathrm{CdO}$ & 0.66 & $\&$ & 0.10 & $\&$ & 0.02 & $\&$ & $<0.01$ & $\&$ & $<0.01$ & $\&$ & $<0.01$ \\
\hline $\mathrm{CeO}_{2}$ & 0.18 & $\&$ & $<0.01$ & $\&$ & $<0.01$ & $\&$ & $<0.01$ & $\&$ & $<0.01$ & $\&$ & $<0.01$ \\
\hline $\mathrm{Cr}_{2} \mathrm{O}_{3}$ & 0.38 & 0.94 & 0.81 & 0.94 & 1.02 & 0.93 & 0.97 & 0.93 & 0.89 & 0.93 & 0.84 \\
\hline $\mathrm{Cs}_{2} \mathrm{O}$ & 0.10 & $\&$ & $<0.01$ & $\&$ & $<0.01$ & $\&$ & $<0.01$ & $\&$ & $<0.01$ & $\&$ & $<0.01$ \\
\hline $\mathrm{F}$ & $0.14^{\#}$ & 0.72 & $0.29^{\#}$ & 0.72 & $0.26^{\#}$ & 0.72 & $0.27^{\#}$ & 0.72 & $0.34^{\%}$ & 0.72 & $0.26^{\#}$ \\
\hline $\mathrm{Fe}_{2} \mathrm{O}_{3}$ & 10.22 & 5.41 & 6.28 & 5.39 & 5.94 & 5.38 & 5.54 & 5.36 & 5.85 & 5.37 & 5.54 \\
\hline $\mathrm{K}_{2} \mathrm{O}$ & 0.18 & 0.28 & 0.32 & 0.28 & 0.31 & 0.28 & 0.29 & 0.28 & 0.27 & 0.28 & 0.27 \\
\hline $\mathrm{La}_{2} \mathrm{O}_{3}$ & 0.12 & $\&$ & $<0.01$ & $\&$ & $<0.01$ & $\&$ & $<0.01$ & $\&$ & $<0.01$ & $\&$ & $<0.01$ \\
\hline $\mathrm{Li}_{2} \mathrm{O}^{*}$ & 3.78 & 2.50 & 2.63 & 2.49 & 2.51 & 2.49 & 2.50 & 2.48 & 2.50 & 2.48 & 2.50 \\
\hline $\mathrm{MgO}$ & 0.18 & 0.13 & 0.19 & 0.13 & 0.16 & 0.13 & 0.17 & 0.13 & 0.17 & 0.13 & 0.17 \\
\hline $\mathrm{MnO}$ & 1.03 & 4.52 & 3.55 & 4.51 & 4.31 & 4.50 & 4.13 & 4.48 & 4.66 & 4.49 & 4.81 \\
\hline $\mathrm{Na}_{2} \mathrm{O}$ & 11.64 & 12.45 & 12.22 & 12.40 & 12.40 & 12.38 & 12.41 & 12.34 & 12.38 & 12.36 & 12.59 \\
\hline $\mathrm{Nd}_{2} \mathrm{O}_{3}$ & 0.16 & $\&$ & 0.05 & $\&$ & $<0.01$ & $\&$ & $<0.01$ & $\&$ & $<0.01$ & $\&$ & $<0.01$ \\
\hline $\mathrm{NiO}$ & 0.98 & 0.87 & 1.02 & 0.86 & 1.09 & 0.86 & 1.03 & 0.86 & 0.99 & 0.86 & 0.98 \\
\hline $\mathrm{P}_{2} \mathrm{O}_{5}$ & 0.66 & 1.56 & 1.43 & 1.55 & 1.50 & 1.55 & 1.55 & 1.55 & 1.52 & 1.55 & 1.50 \\
\hline $\mathrm{PbO}$ & 0.02 & 0.19 & 0.16 & 0.19 & 0.17 & 0.19 & 0.17 & 0.19 & 0.18 & 0.19 & 0.18 \\
\hline $\mathrm{SO}_{3}$ & 0.30 & 0.95 & 0.73 & 1.30 & 0.92 & 1.50 & 1.12 & 1.78 & 1.03 & 1.63 & 1.11 \\
\hline $\mathrm{SiO}_{2}$ & 44.73 & 40.89 & 41.94 & 40.74 & 40.50 & 40.66 & 40.89 & 40.54 & 40.34 & 40.61 & 40.48 \\
\hline $\mathrm{SnO}_{2}$ & 0.16 & $\&$ & 0.02 & $\&$ & $<0.01$ & $\&$ & $<0.01$ & $\&$ & $<0.01$ & $\&$ & $<0.01$ \\
\hline $\mathrm{SrO}$ & 0.13 & 1.03 & 0.87 & 1.02 & 1.02 & 1.02 & 0.99 & 1.02 & 1.02 & 1.02 & 0.97 \\
\hline $\mathrm{TiO}_{2}$ & 0.08 & $\&$ & 0.03 & $\&$ & 0.01 & $\&$ & 0.03 & $\&$ & $<0.01$ & $\&$ & 0.03 \\
\hline $\mathrm{ZnO}$ & 1.75 & $\&$ & 0.31 & $\&$ & 0.10 & $\&$ & 0.04 & $\&$ & 0.03 & $\&$ & 0.02 \\
\hline $\mathrm{ZrO}_{2}$ & 2.77 & 0.07 & 0.59 & 0.07 & 0.30 & 0.07 & 0.26 & 0.07 & 0.27 & 0.07 & 0.09 \\
\hline Sum & 100.00 & 100.00 & 100.00 & 100.00 & 100.00 & 100.00 & 100.00 & 100.00 & 100.00 & 100.00 & 100.00 \\
\hline
\end{tabular}


Table 5.11. Concentrations [ppmv] of Selected Species in Off-Gas Measured by FTIR Spectroscopy While Processing the HLWS-27 Formulation.

\begin{tabular}{|c|c|c|c|c|c|c|c|c|c|c|}
\hline \multirow{2}{*}{ Test } & \multicolumn{2}{|r|}{$\mathbf{A}$} & \multicolumn{2}{|r|}{ B } & \multicolumn{2}{|r|}{ C } & \multicolumn{2}{|r|}{ D } & \multicolumn{2}{|r|}{$\mathbf{E}$} \\
\hline & Avg. & Range & Avg. & Range & Avg. & Range & Avg. & Range & Avg. & Range \\
\hline $\mathrm{N}_{2} \mathrm{O}$ & $<1.0$ & $<1.0-1.7$ & $<1.0$ & $<1.0-1.8$ & $<1.0$ & $<1.0-1.2$ & $<1.0$ & $<1.0-1.1$ & $<1.0$ & $<1.0-1.0$ \\
\hline $\mathrm{NO}$ & 26.7 & $14.0-68.8$ & 26.7 & $2.6-66.9$ & 28.1 & $2.7-51.0$ & 27.6 & $<1.0-45.5$ & 26.8 & $12.9-42.2$ \\
\hline $\mathrm{NO}_{2}$ & 6.4 & $2.9-16.6$ & 5.6 & $<1.0-16.4$ & 5.8 & $<1.0-9.6$ & 5.8 & $<1.0-8.7$ & 6.3 & $2.5-9.6$ \\
\hline $\mathrm{NH}_{3}$ & $<1.0$ & $<1.0-2.6$ & $<1.0$ & NA & $<1.0$ & NA & $<1.0$ & NA & $<1.0$ & NA \\
\hline $\mathrm{H}_{2} \mathrm{O}[\%]$ & 1.8 & $1.1-3.8$ & 1.7 & $0.5-3.9$ & 2.4 & $0.9-3.3$ & 2.1 & $0.7-2.6$ & 2.1 & $1.3-2.8$ \\
\hline $\mathrm{CO}_{2}$ & 719 & $580-1278$ & 720 & $470-1255$ & 729 & $479-937$ & 731 & $461-926$ & 720 & $585-842$ \\
\hline Nitrous Acid & $<1.0$ & NA & $<1.0$ & NA & $<1.0$ & NA & $<1.0$ & NA & $<1.0$ & NA \\
\hline Nitric Acid & $<1.0$ & $<1.0-1.9$ & 2.1 & $<1.0-2.7$ & 2.3 & $<1.0-4.3$ & 2.7 & $1.6-5.3$ & 2.7 & $1.9-4.0$ \\
\hline $\mathrm{HCN}$ & $<1.0$ & NA & $<1.0$ & NA & $<1.0$ & NA & $<1.0$ & NA & $<1.0$ & NA \\
\hline $\mathrm{CO}$ & 1.1 & $<1.0-4.1$ & 1.1 & $<1.0-2.2$ & 1.1 & $<1.0-4.2$ & 1.2 & $<1.0-2.1$ & 1.2 & $<1.0-2.0$ \\
\hline $\mathrm{HCl}$ & $<1.0$ & NA & $<1.0$ & $<1.0-1.0$ & $<1.0$ & $\mathrm{NA}$ & $<1.0$ & $\mathrm{NA}$ & $<1.0$ & NA \\
\hline $\mathrm{HF}$ & $<1.0$ & NA & $<1.0$ & NA & $<1.0$ & NA & $<1.0$ & $<1.0-1.1$ & 1.0 & $<1.0-1.2$ \\
\hline $\mathrm{SO}_{2}$ & $<1.0$ & NA & $<1.0$ & NA & $<1.0$ & NA & $<1.0$ & NA & $<1.0$ & NA \\
\hline
\end{tabular}

NA : Not applicable. 


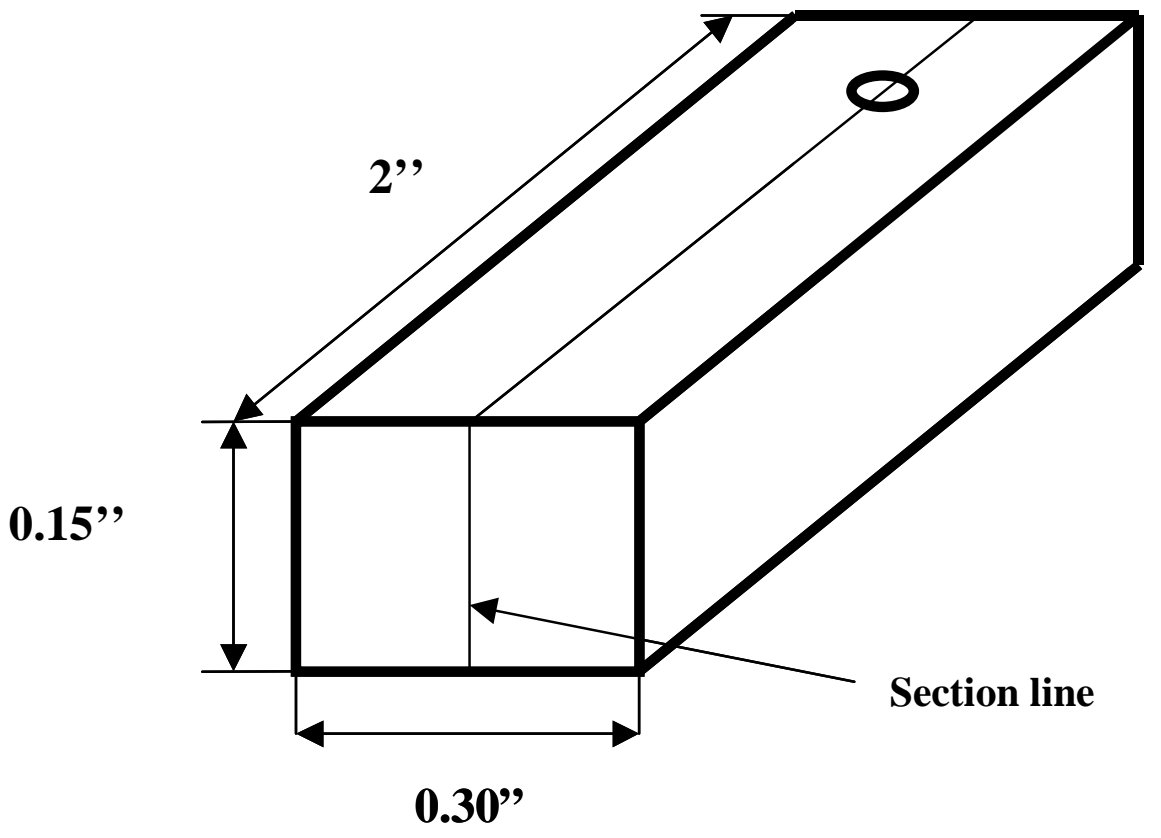

Figure 1.1. Schematic diagram of a metal coupon showing typical dimensions and line indicating where the coupon is sectioned after testing. 


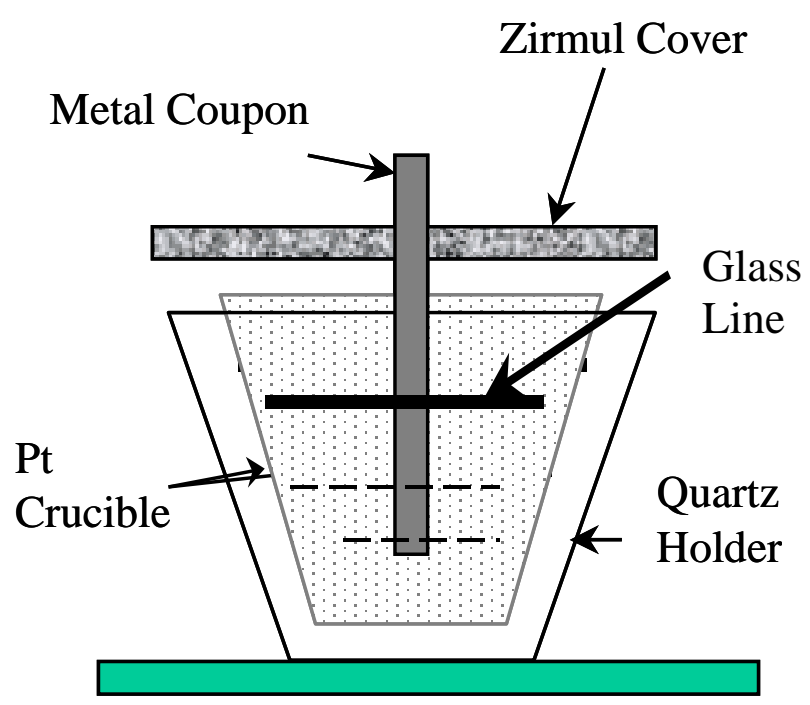

Figure 1.2. Experimental set up for standard metal corrosion tests. 
The Catholic University of America

Vitreous State Laboratory
Management High Sulfur HLW Final Report, VSL-13R2920-1, Rev. 0

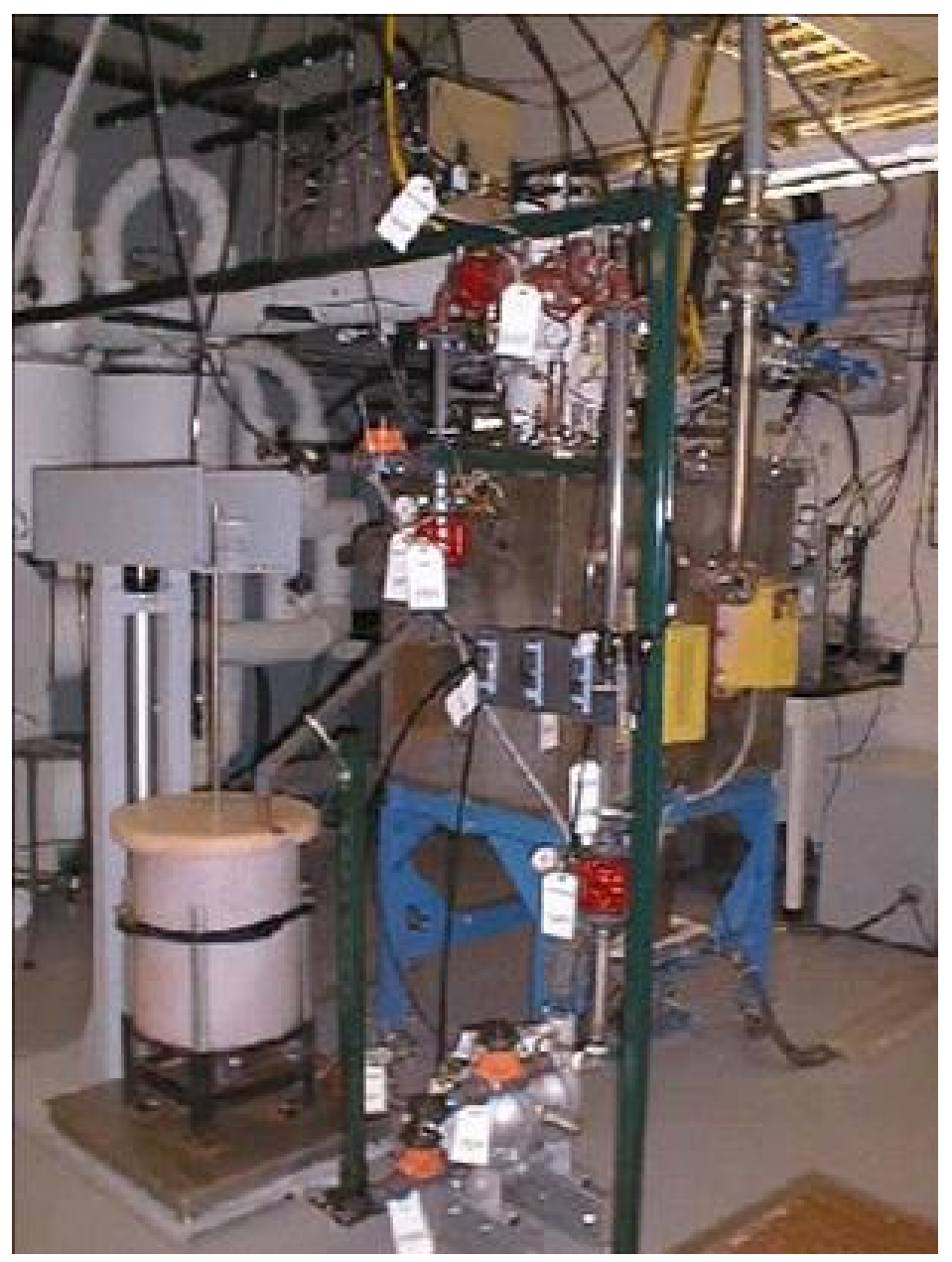

Figure 1.3. DM10 melter and feed tank; off-gas system is in the background to the left. 


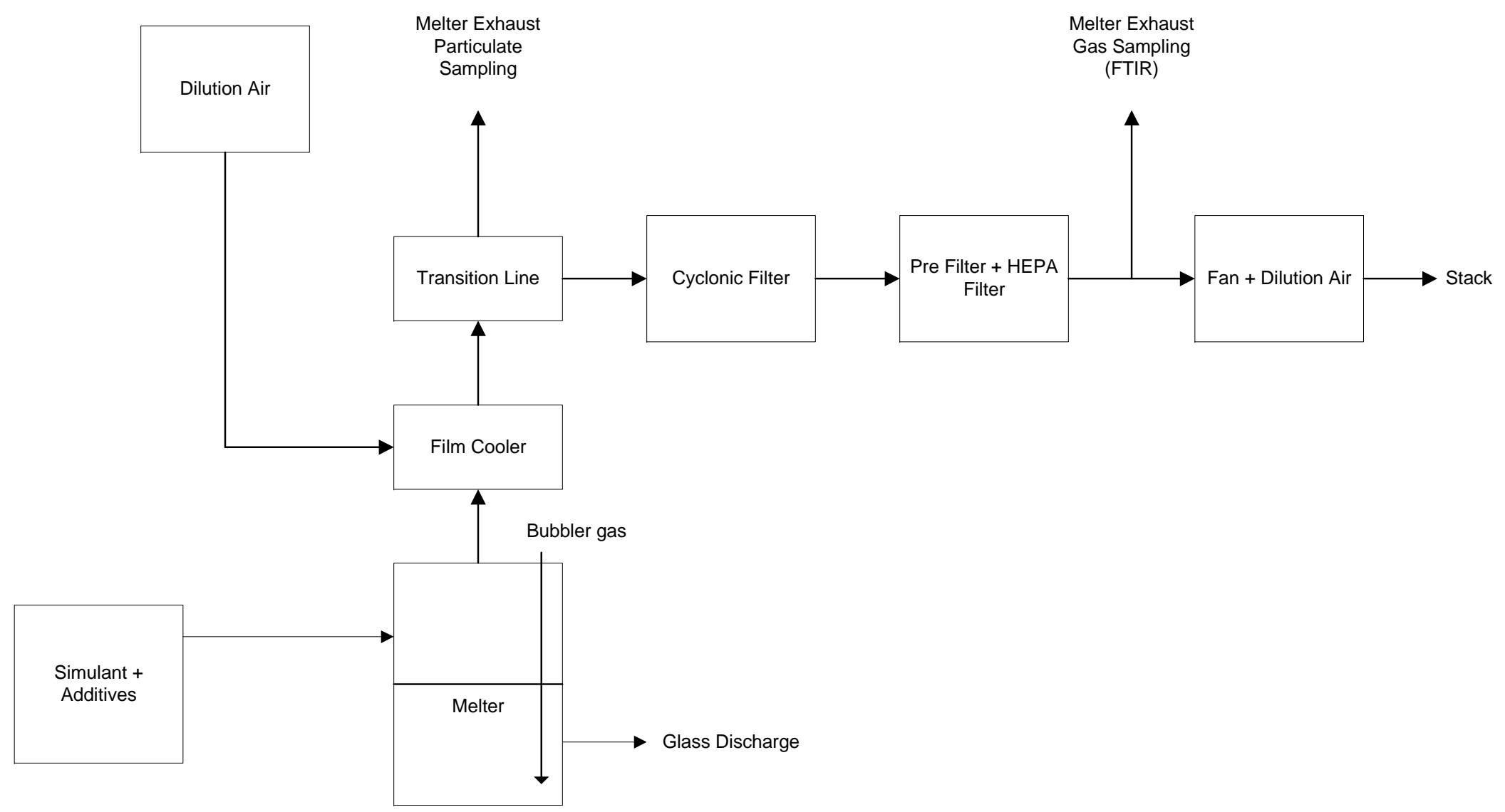

Figure 1.4. Schematic diagram of DM 10 vitrification system. 


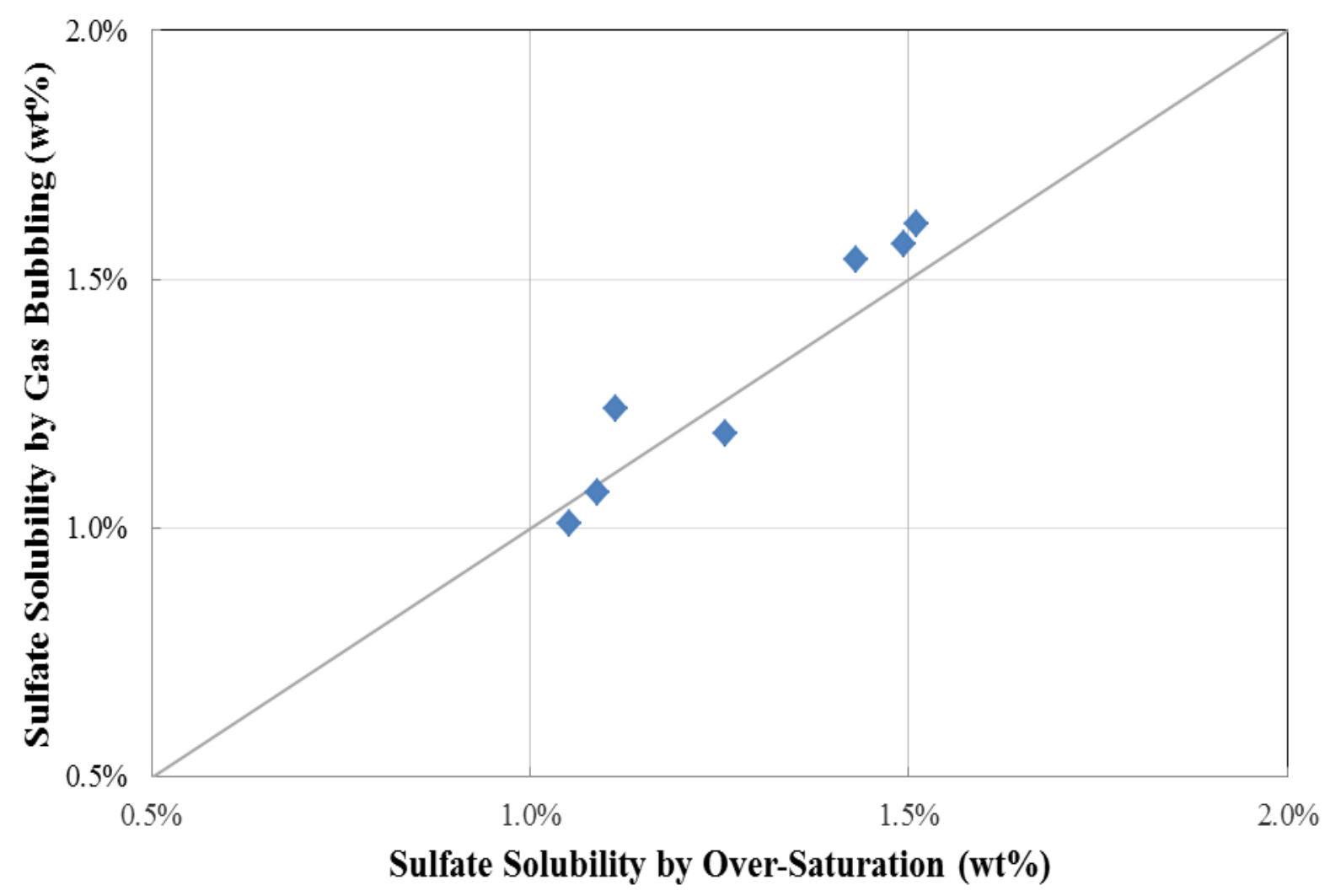

Figure 2.1. Sulfate solubility (as wt\% $\mathrm{SO}_{3}$ ) measured by over-saturation melting and gas bubbling. 


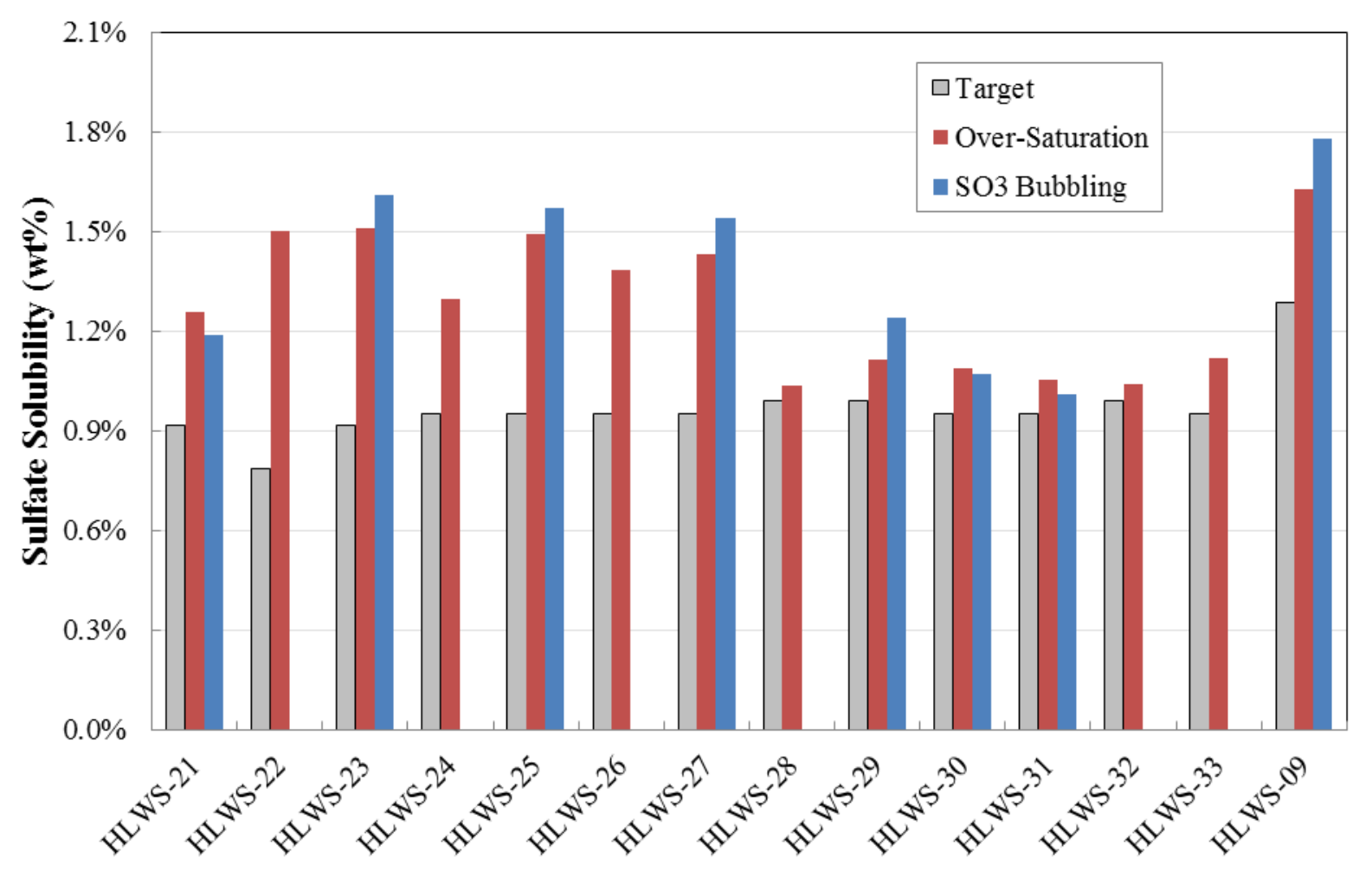

Figure 2.2. Comparison of sulfate solubilities (as wt \% $\mathrm{SO}_{3}$ ) measured for $\mathrm{HLWS}$ glasses with target $\mathrm{SO}_{3}$ values (target refers to target $\mathrm{SO}_{3}$ concentration in the nominal glass composition). 


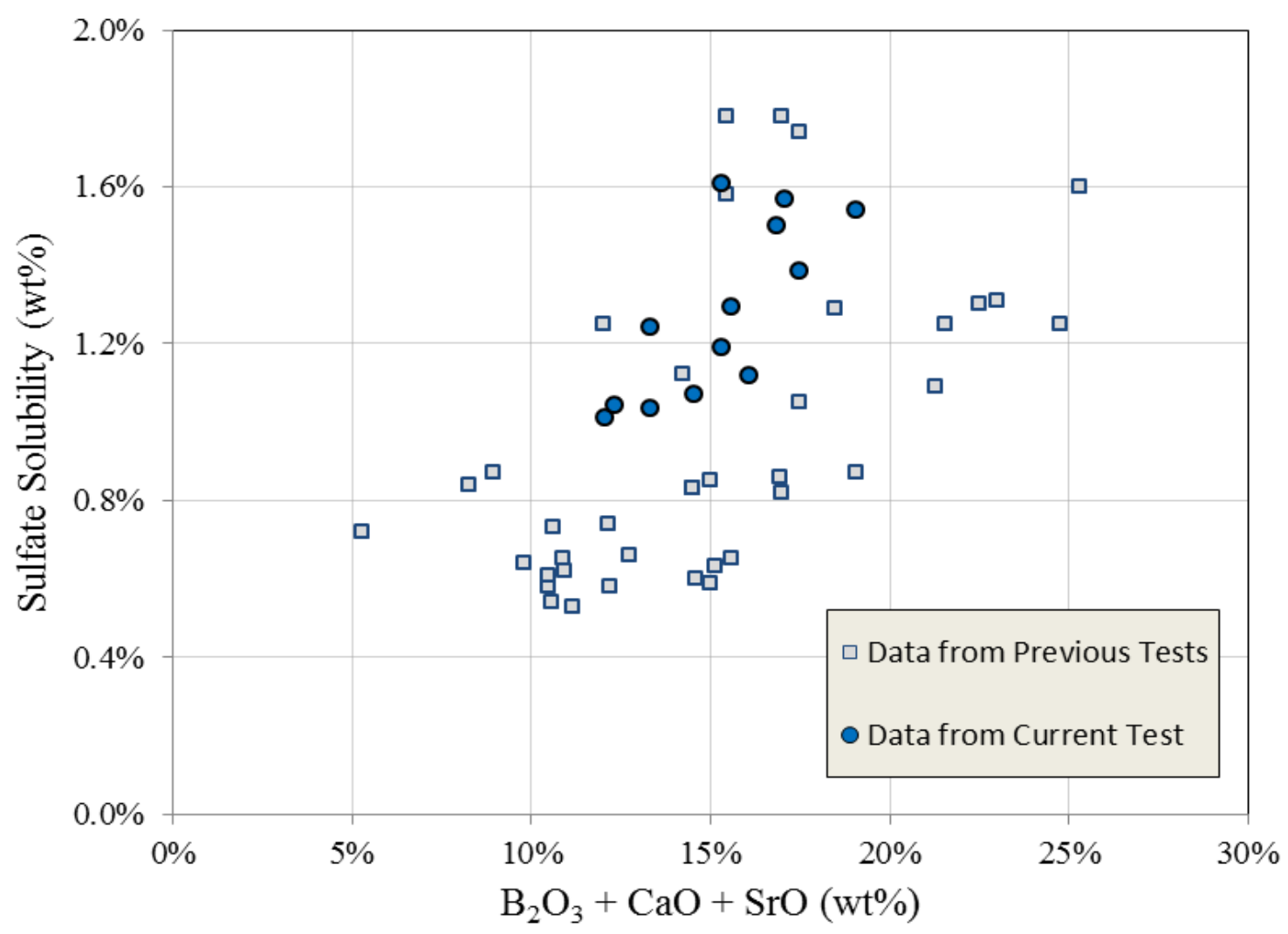

Figure 2.3. Measured sulfate solubilities versus $\left(\mathrm{B}_{2} \mathrm{O}_{3}+\mathrm{CaO}+\mathrm{SrO}\right)$ for current $\mathrm{HLWS}$ glasses and 39 other $\mathrm{HLW}$ glass formulations [26]. (Data from over-saturation are used for current glasses with no gas bubbling data.) 

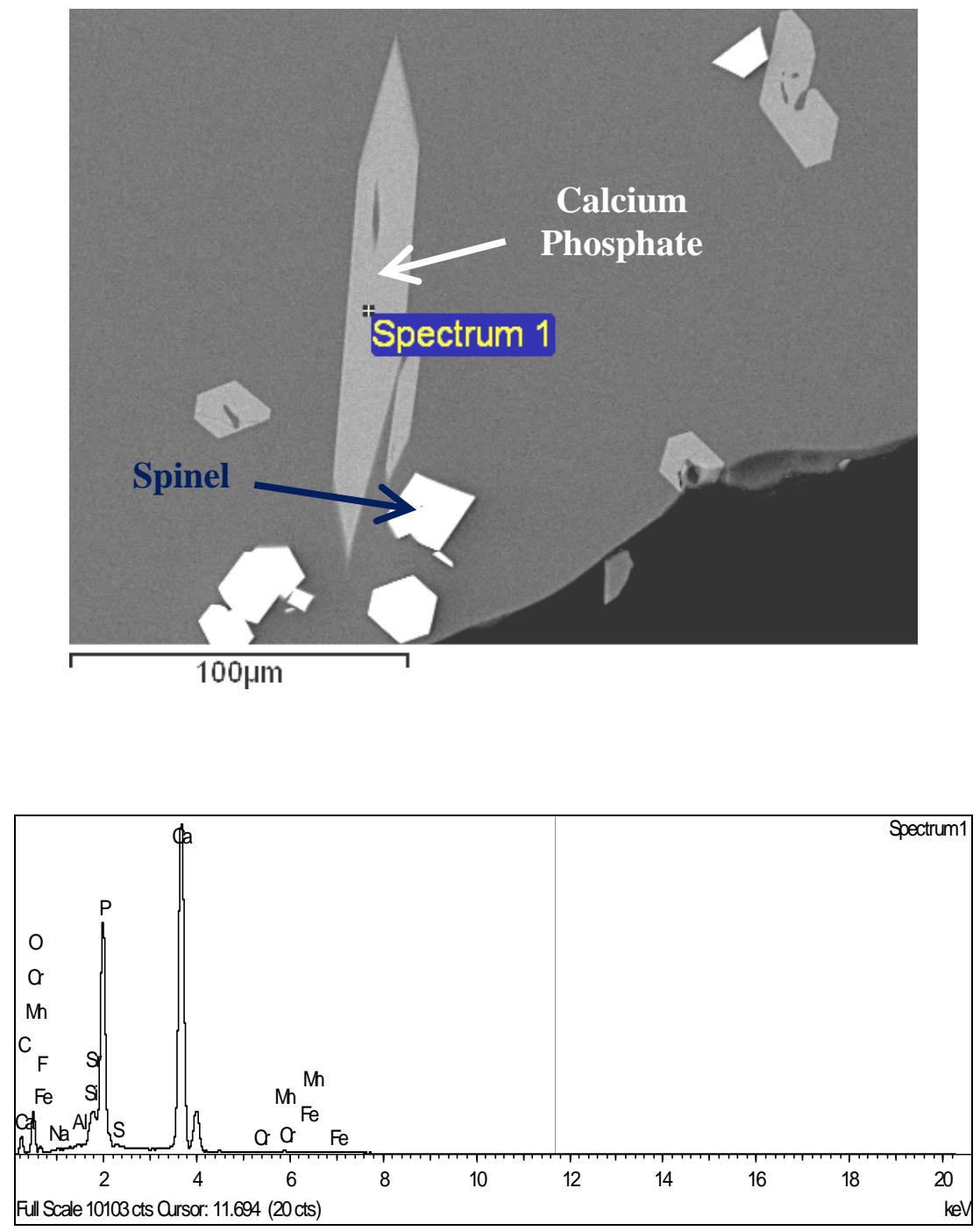

Figure 2.4. Scanning electron micrograph of HLWS-27 heat treated at $900^{\circ} \mathrm{C}$ and 70 hours (top) and EDS spectrum of calcium phosphate crystal (bottom). 


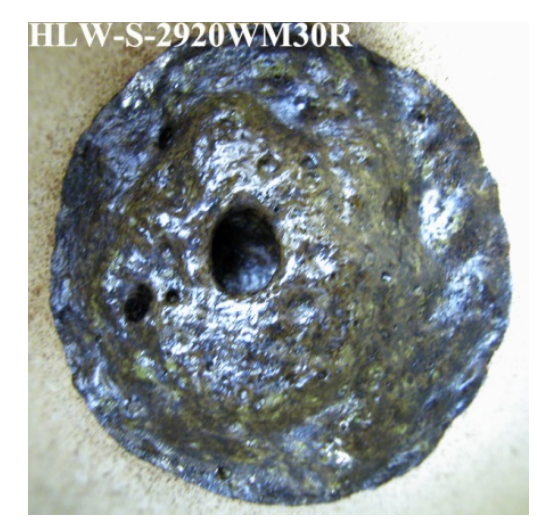

Top view after 30 minute test in VGF

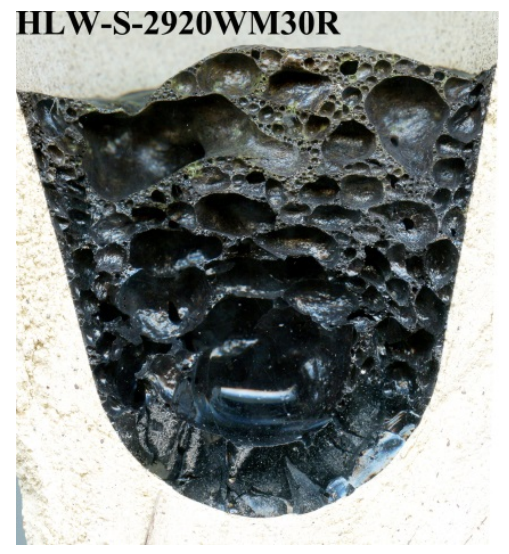

Cross section after 30 minute test in VGF

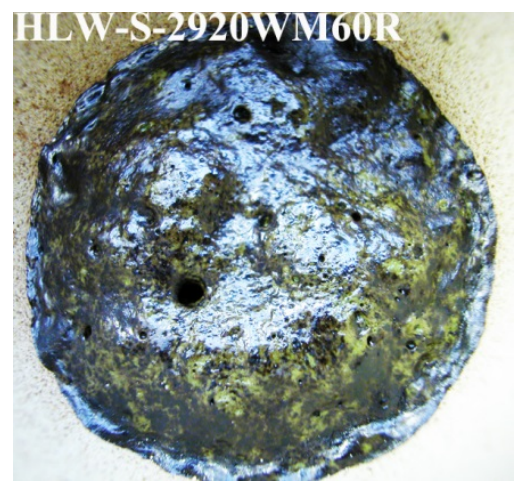

Top view after 60 minute test in VGF

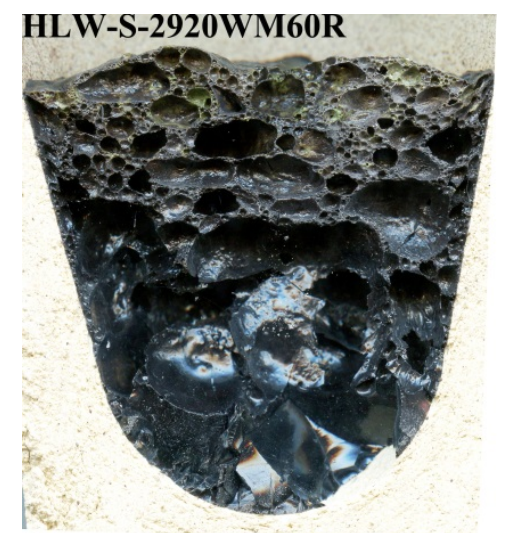

Cross section after 60 minute test in VGF

Figure 2.5. Images of feed sample of HLWS-27 after vertical gradient furnace tests. 
ORP-56310 Rev. 0

The Catholic University of America

Management High Sulfur HLW

Vitreous State Laboratory

Final Report, VSL-13R2920-1, Rev. 0

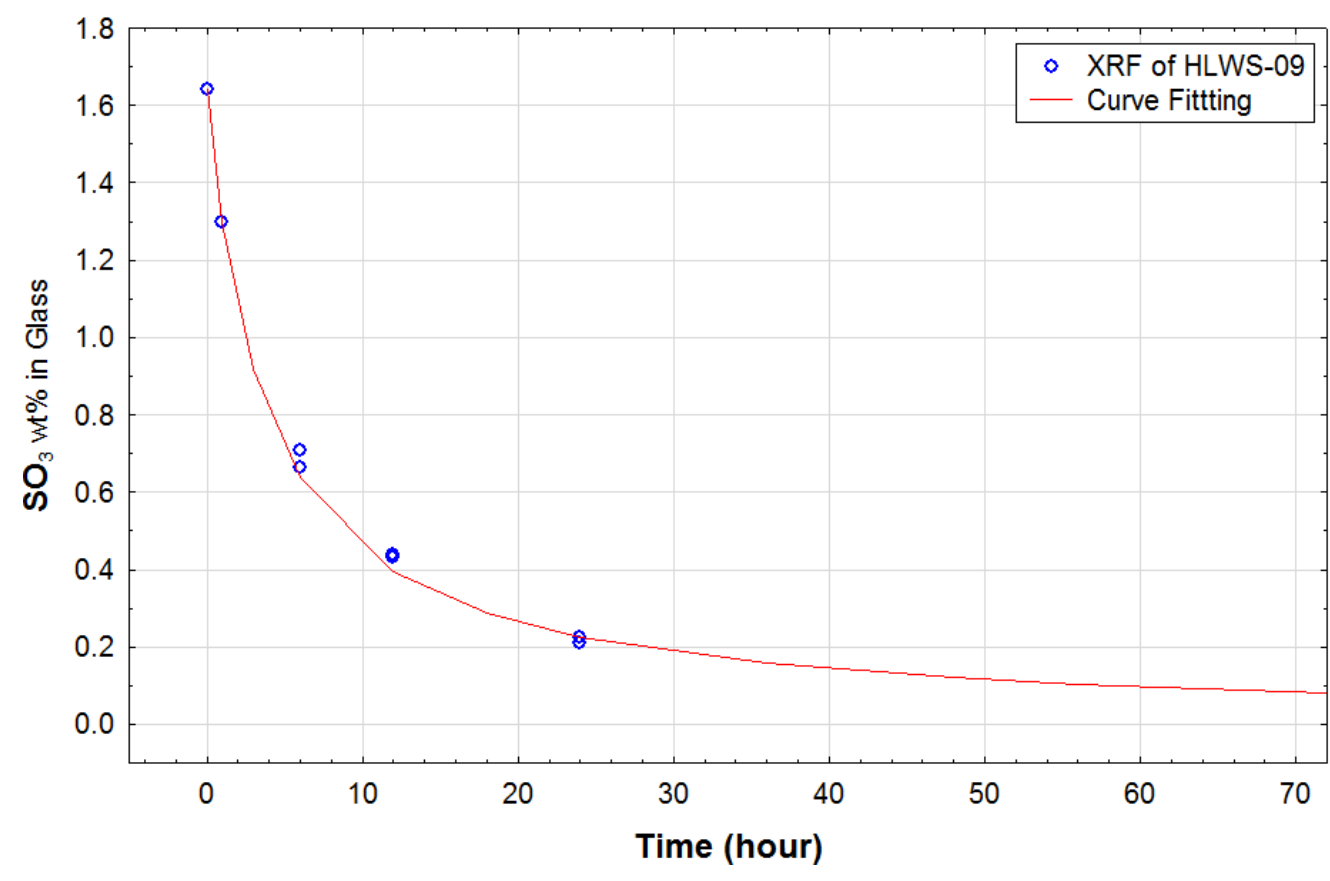

Figure 3.1(a). Sulfate loss curves from XRF analysis of HLWS-09 glass samples from standard open crucible test at $1150^{\circ} \mathrm{C}$. 
ORP-56310 Rev. 0

The Catholic University of America

Management High Sulfur HLW

Vitreous State Laboratory

Final Report, VSL-13R2920-1, Rev. 0

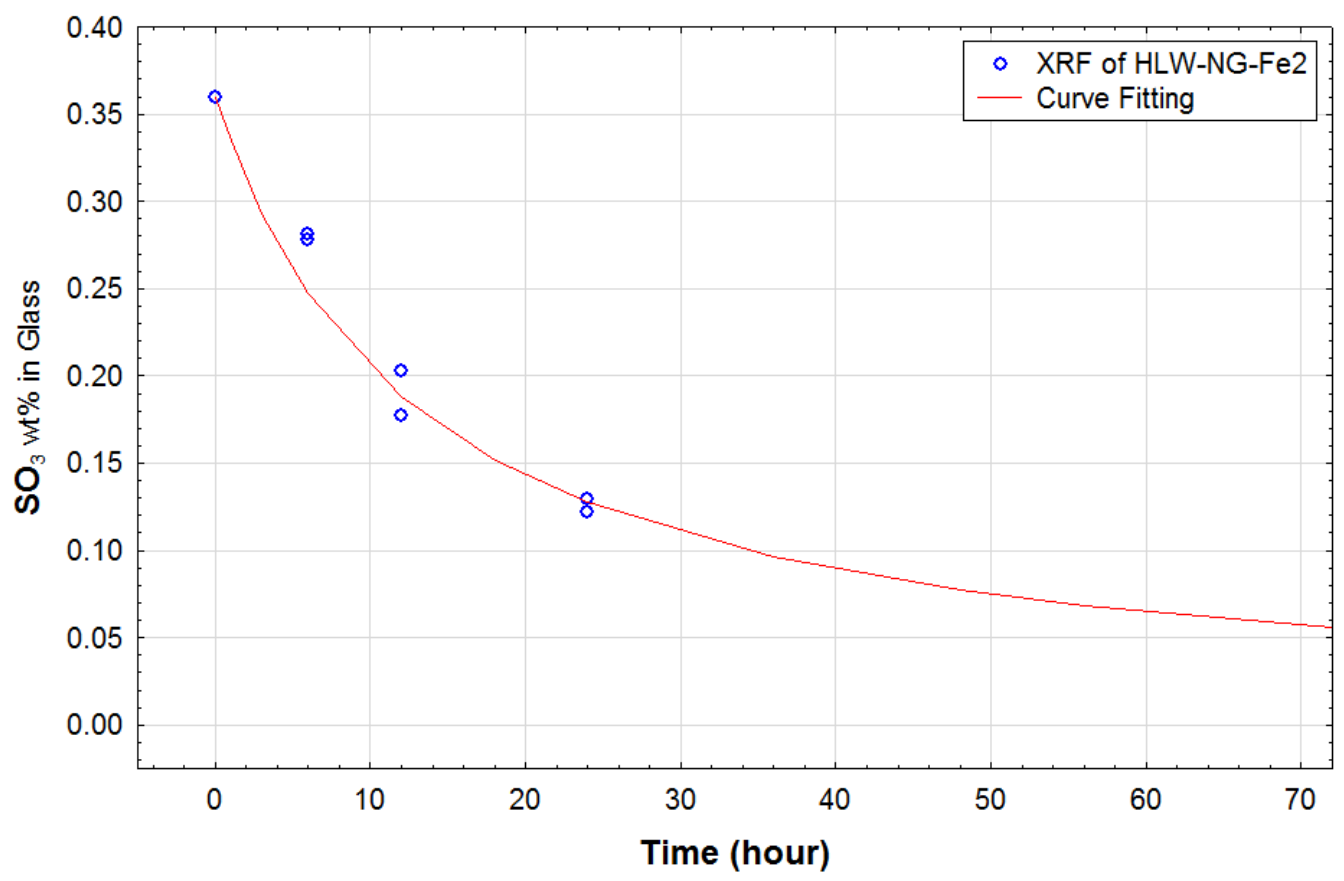

Figure 3.1 (b). Sulfate loss curves from XRF analysis of HLW-NG-Fe2 glass samples from standard open crucible test at $1150^{\circ} \mathrm{C}$. 


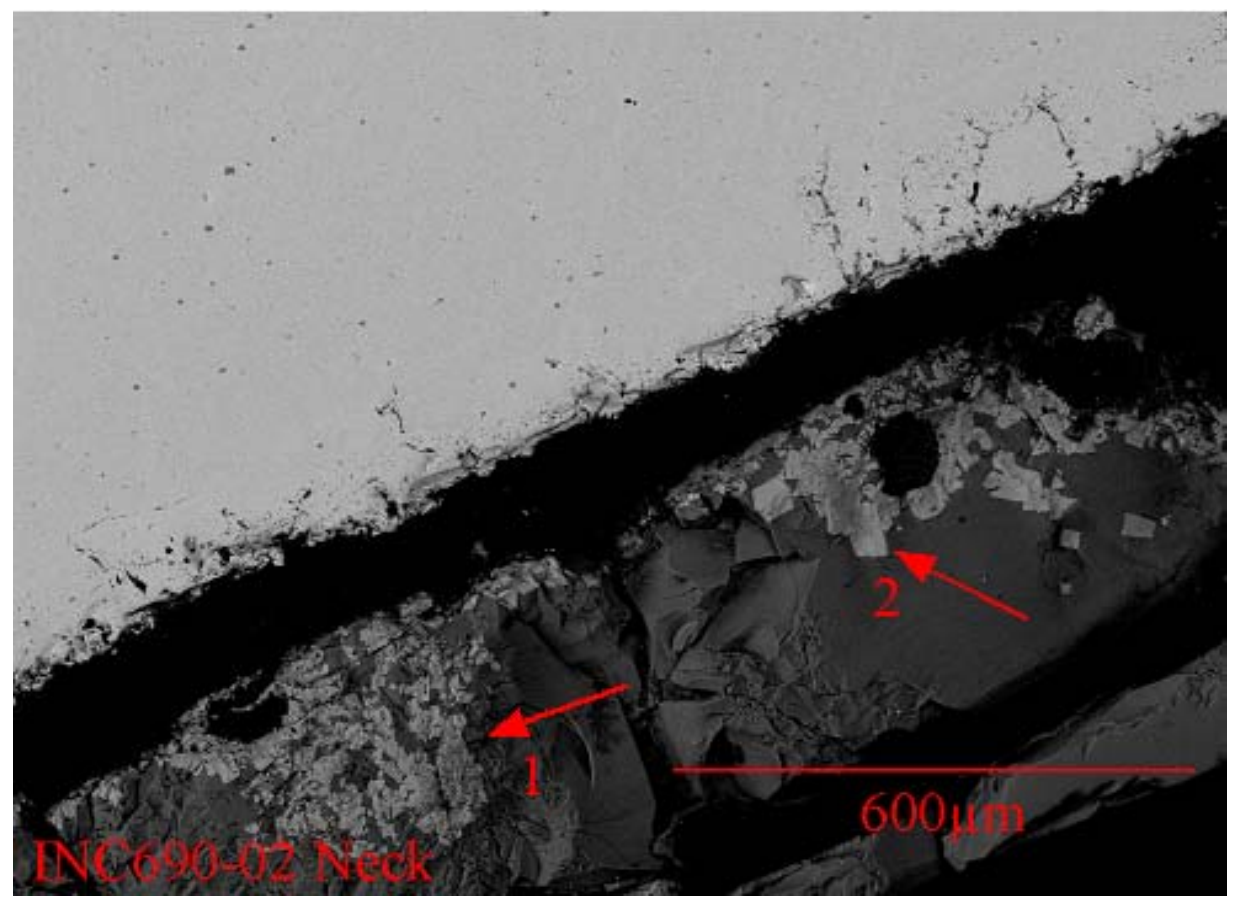

Figure 3.2(a). SEM image of Inconel 690 test coupon after 7-day standard metal corrosion test in HLW-NG-Fe2 glass melt at $1150^{\circ} \mathrm{C}$ showing neck area. The upper left portion of the image in bright grey is a cross section of the Inconel 690 coupon, lower right portion in dark grey is glass at the coupon surface. Grey aggregates denoted by arrows are chromium oxide (1) and spinel containing $\mathrm{Cr}$, Fe, and $\mathrm{Ni}(2)$. 


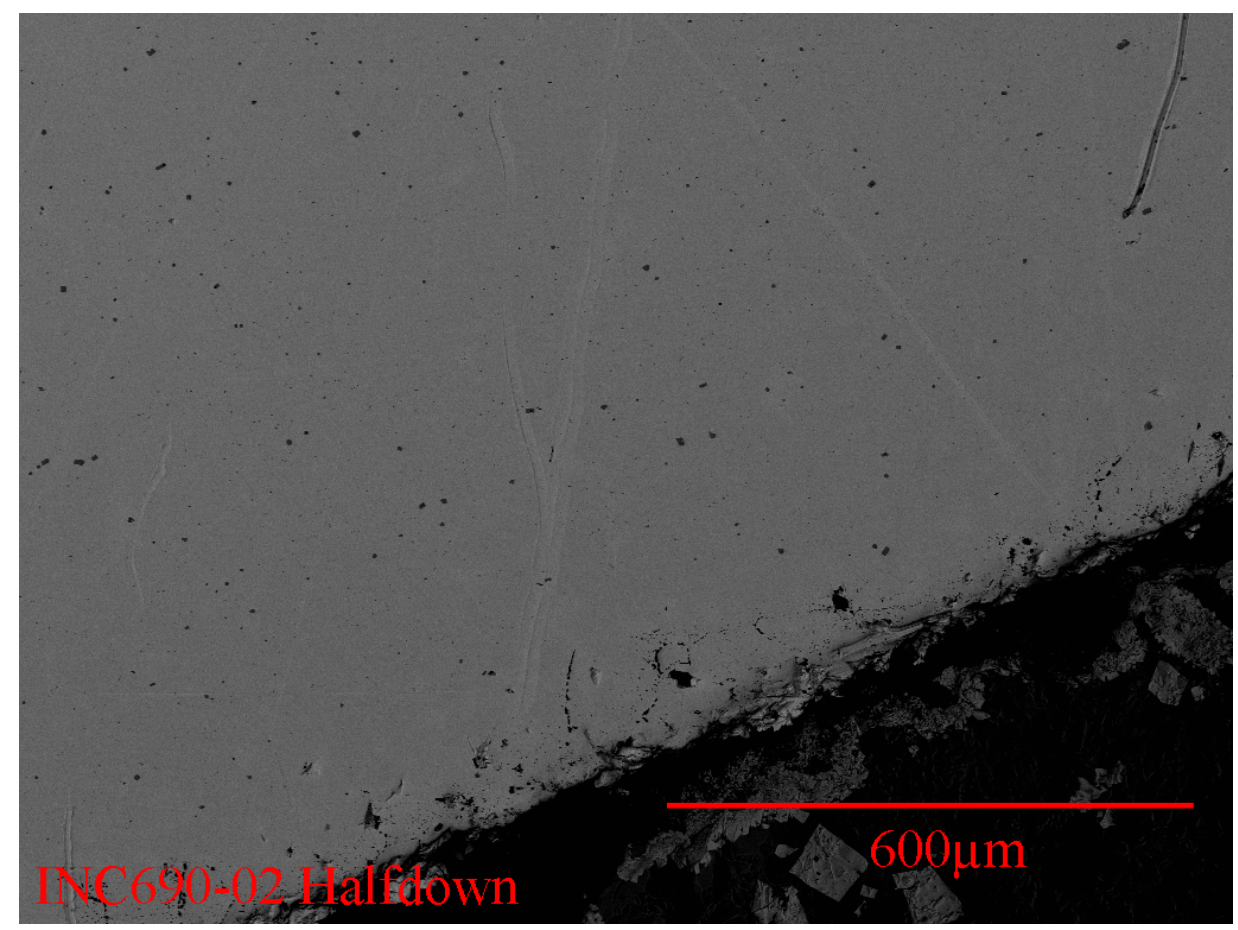

Figure 3.2(b). SEM image of Inconel 690 test coupon after 7-day standard metal corrosion test in HLW-NG-Fe2 glass melt at $1150^{\circ} \mathrm{C}$ showing half-down area. 


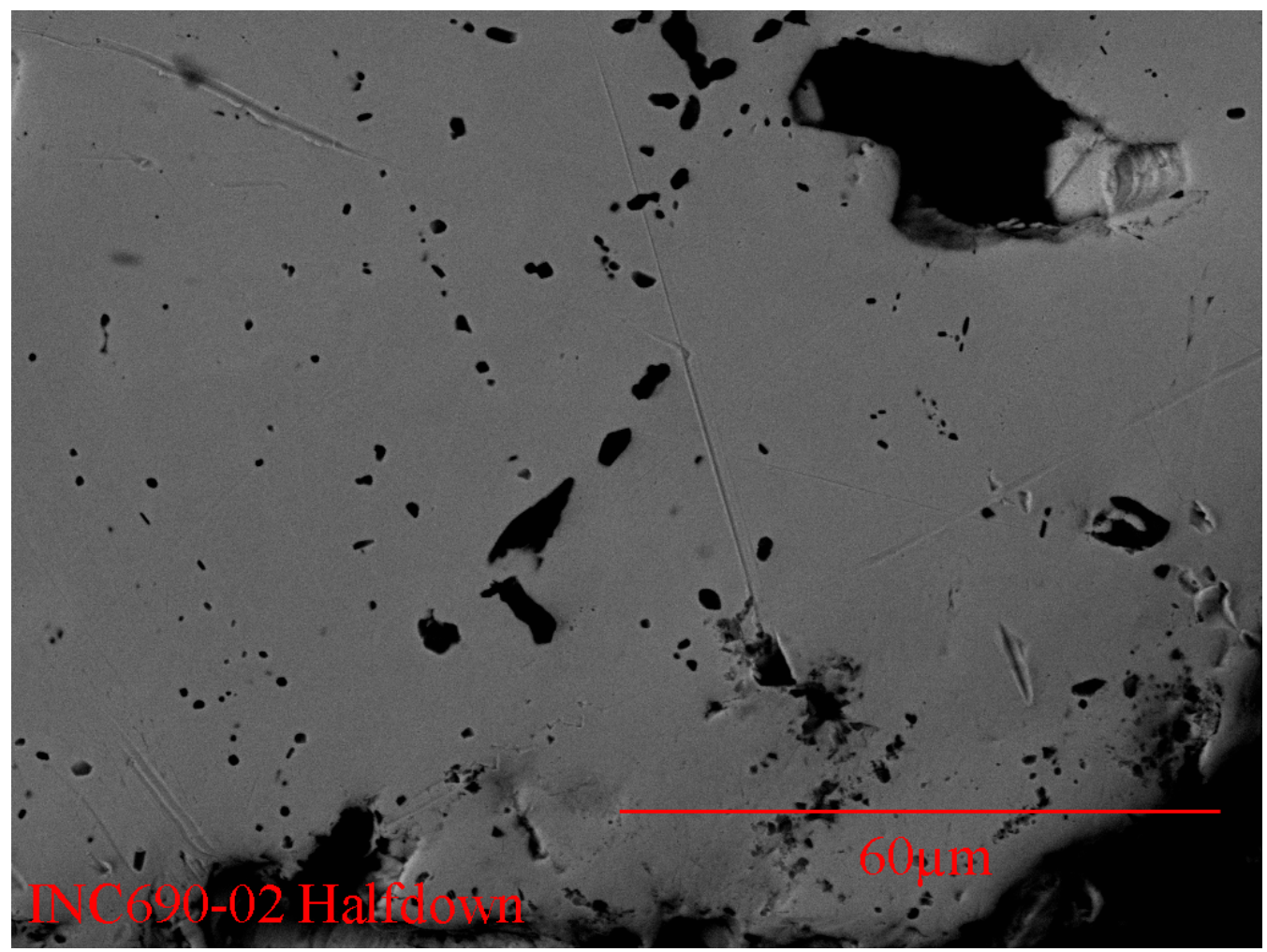

Figure 3.2(c). SEM image of Inconel 690 test coupon after 7-day standard metal corrosion test in HLW-NG-Fe2 glass melt at $1150^{\circ} \mathrm{C}$ showing a close-up view of half-down area. 


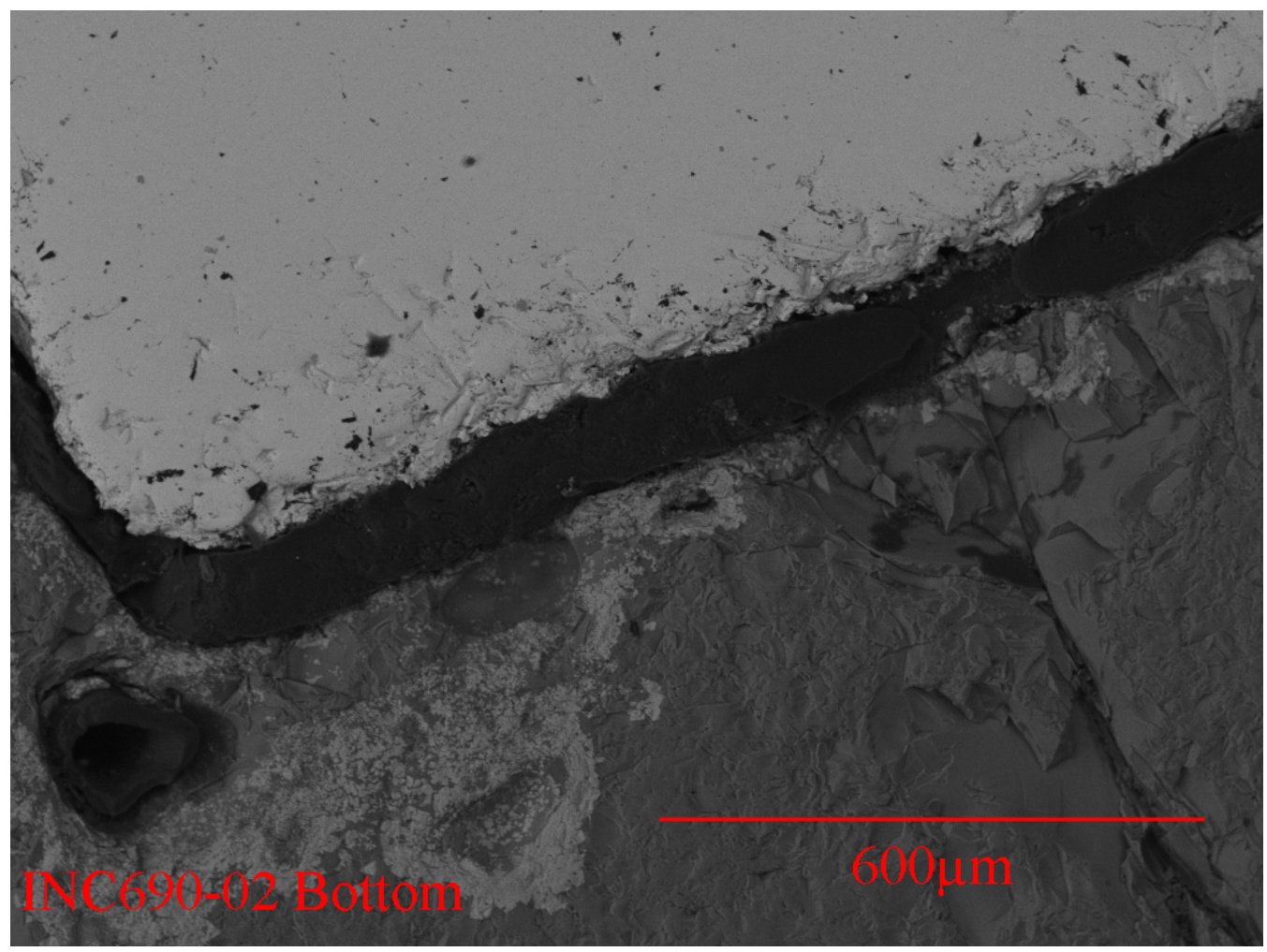

Figure 3.2(d). SEM image of Inconel 690 test coupon after 7-day standard metal corrosion test in HLW-NG-Fe2 glass melt at $1150^{\circ} \mathrm{C}$ showing the area near the tip of the test coupon. 


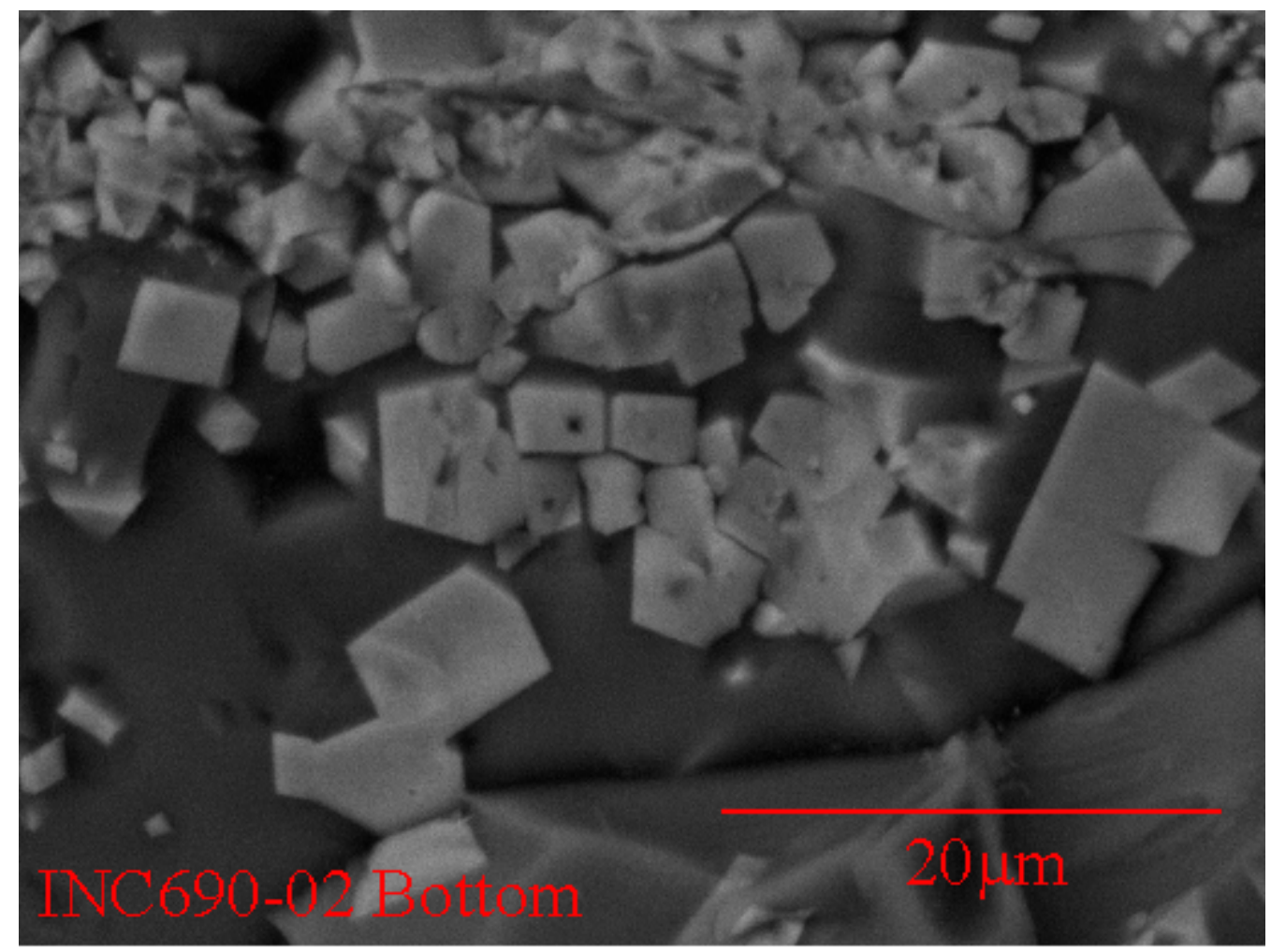

Figure 3.2(e). SEM image of Inconel 690 test coupon after 7-day standard metal corrosion test in HLW-NG-Fe2 glass melt at $1150^{\circ} \mathrm{C}$ showing detailed view of spinel formation near the tip of the test coupon. 


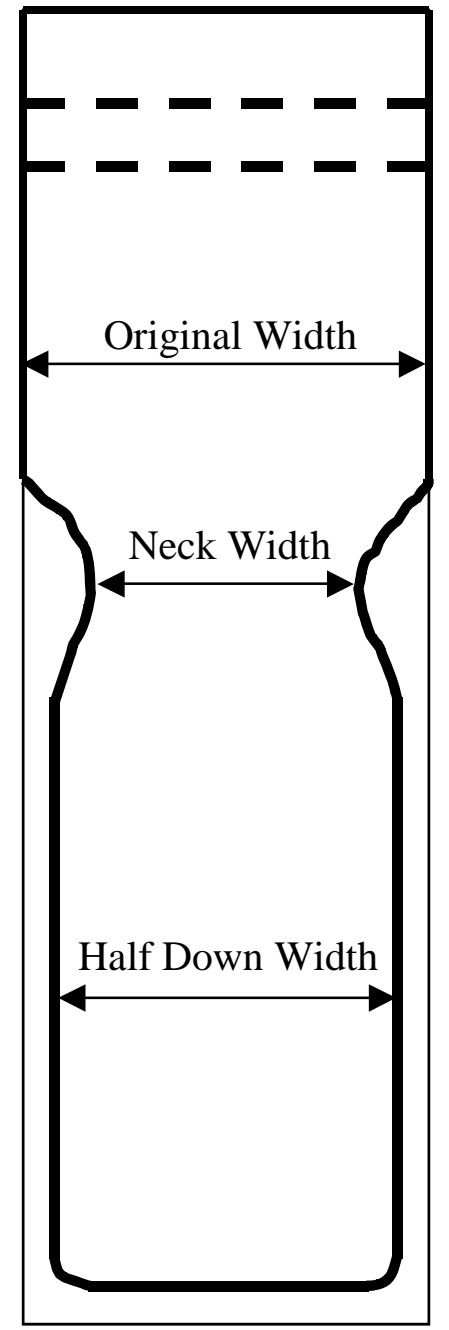

Figure 3.3. Schematic diagram of the cross section of a reacted metal coupon after a typical glass contact corrosion test. 


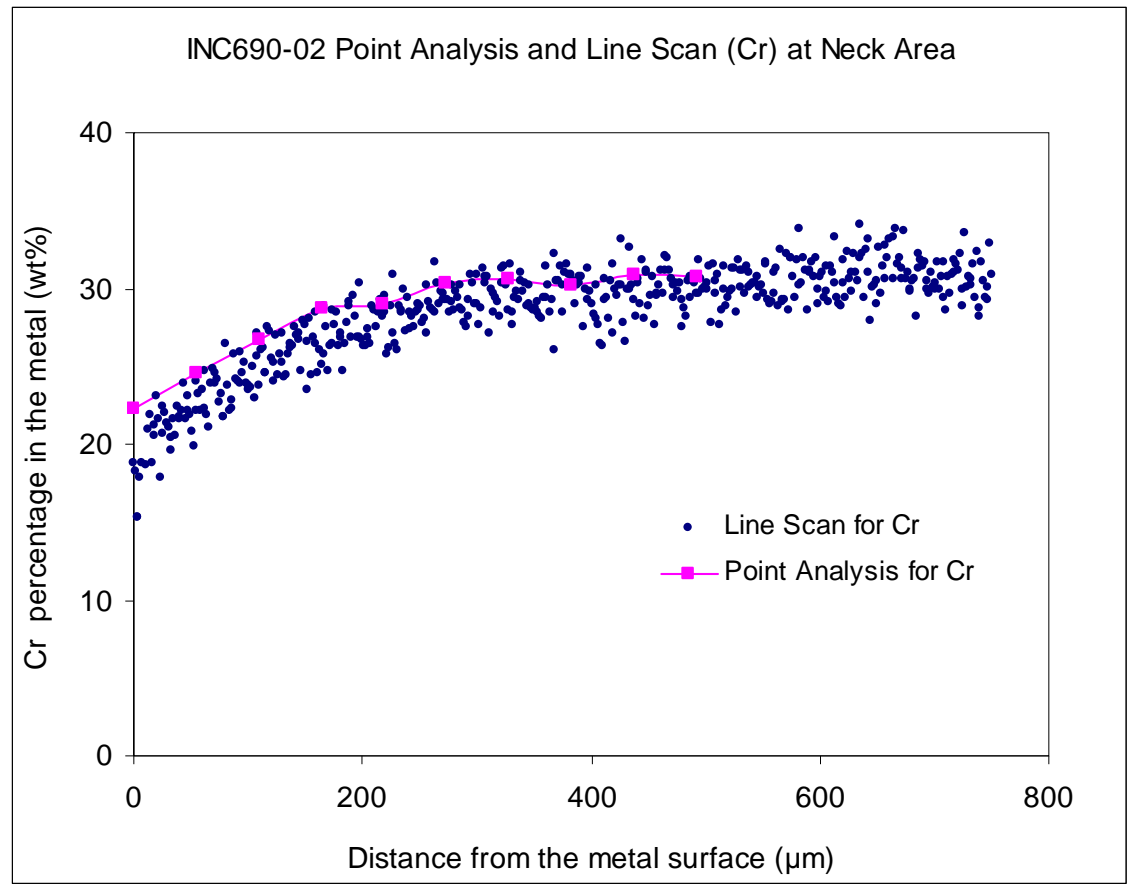

a) Inconel690 in neck area

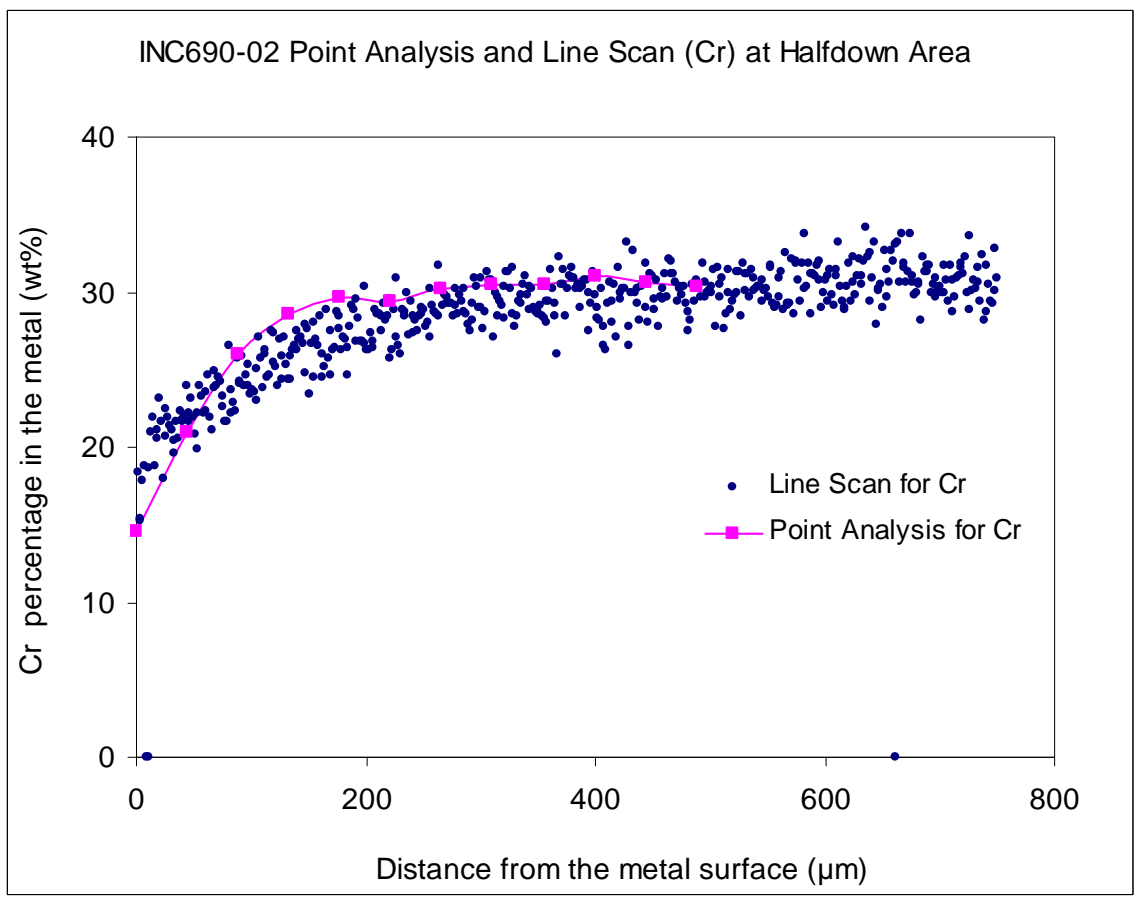

b) Inconel690 in half down area

Figure 3.4. Concentration profiles of $\mathrm{Cr}$ in Inconel 690 test coupon by SEM/EDS after 7-day standard metal corrosion test in $\mathrm{HLW}-\mathrm{NG}-\mathrm{Fe} 2$ at $1150^{\circ} \mathrm{C}$. 


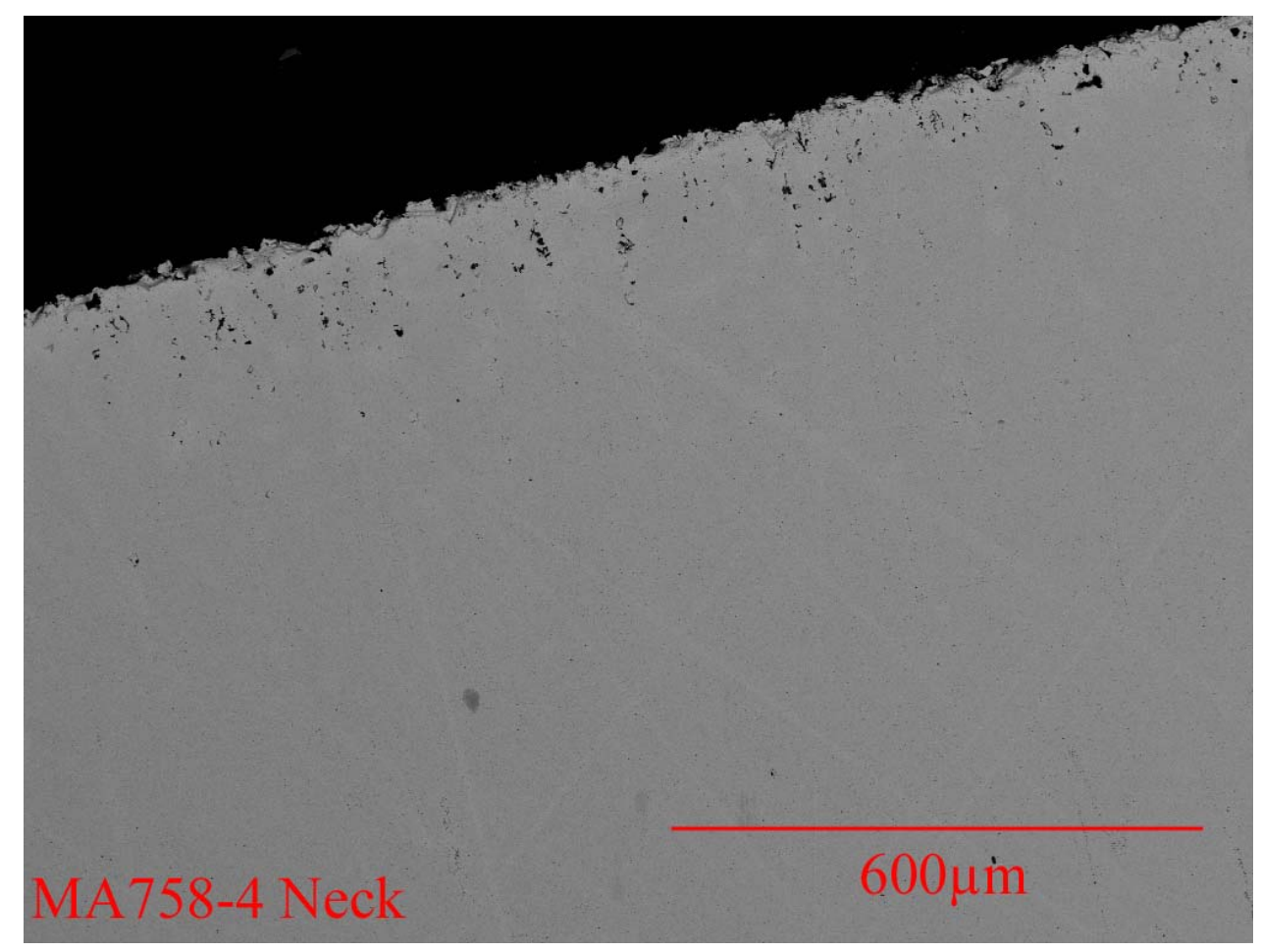

Figure 3.5(a). SEM image of MA758 test coupon after 7-day standard metal corrosion test in $\mathrm{HLW}-\mathrm{NG}-\mathrm{Fe} 2$ glass melt at $1150^{\circ} \mathrm{C}$ showing the neck area.

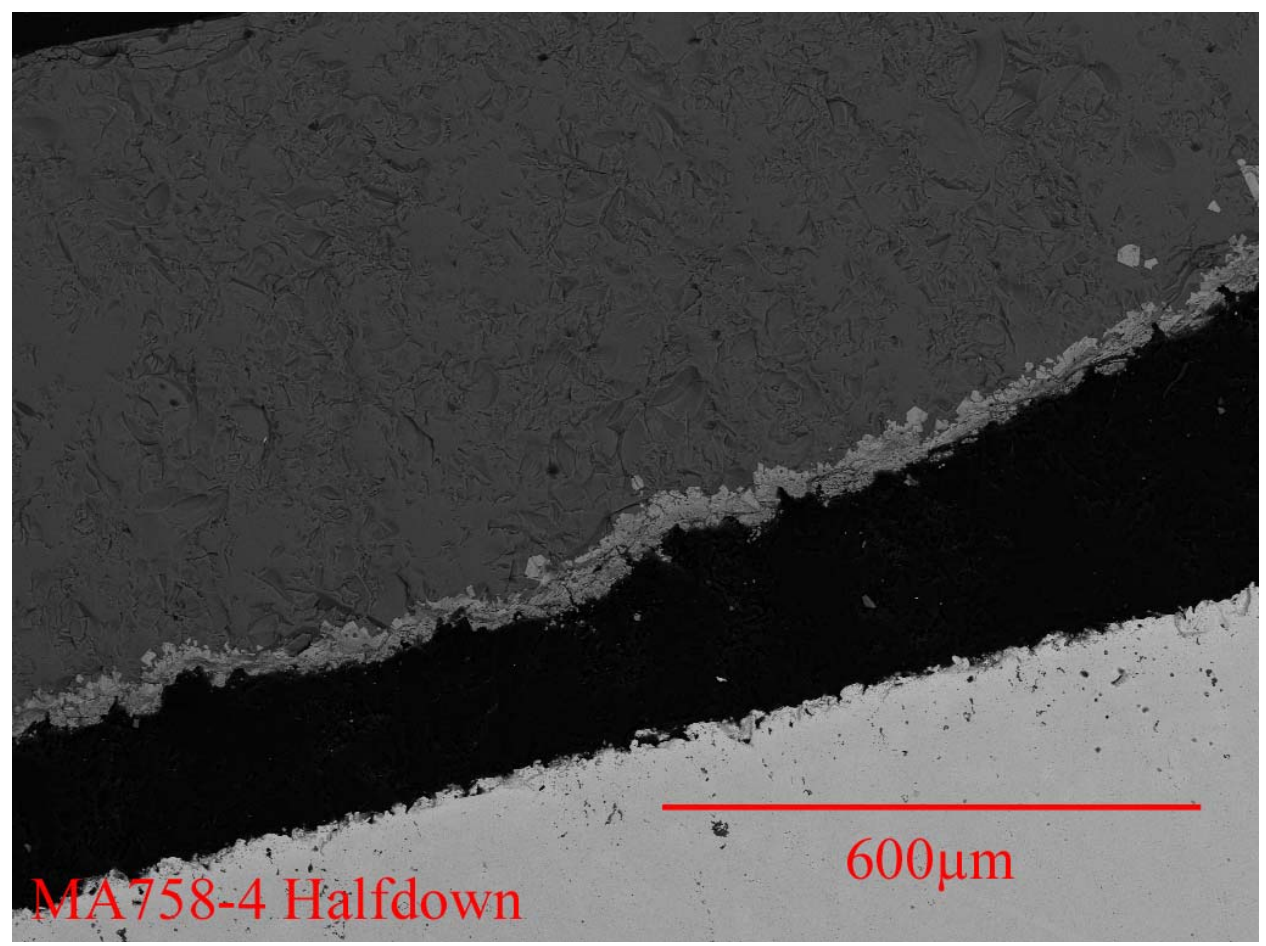

Figure 3.5(b). SEM image of MA758 test coupon after 7-day standard metal corrosion test in $\mathrm{HLW}$-NG-Fe2 glass melt at $1150^{\circ} \mathrm{C}$ showing half-down area. The light grey strip is the chromium oxide scale detached from the test coupon (bright lower portion of the image). 


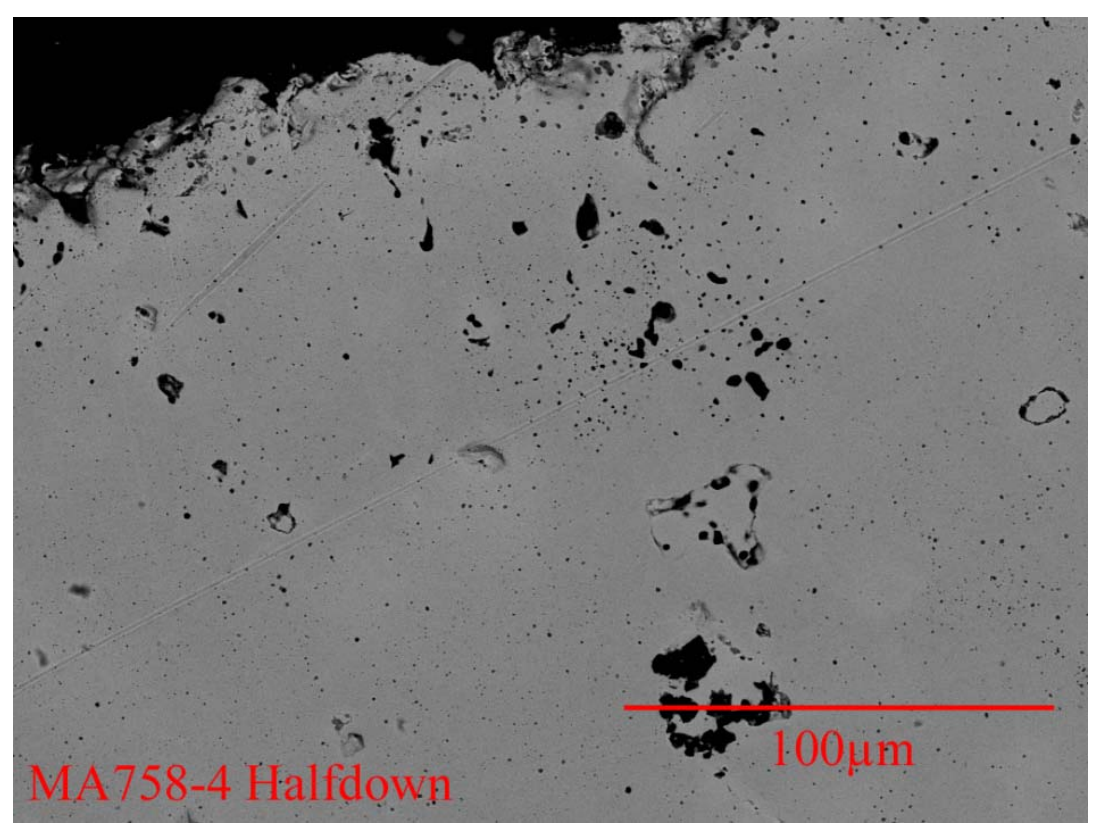

Figure 3.5(c). SEM image of MA758 test coupon after 7-day standard metal corrosion test in HLW-NG-Fe2 glass melt at $1150^{\circ} \mathrm{C}$ showing a close up view of the half-down area. The isolated black inclusions of various sizes are oxide phases within the alloy.

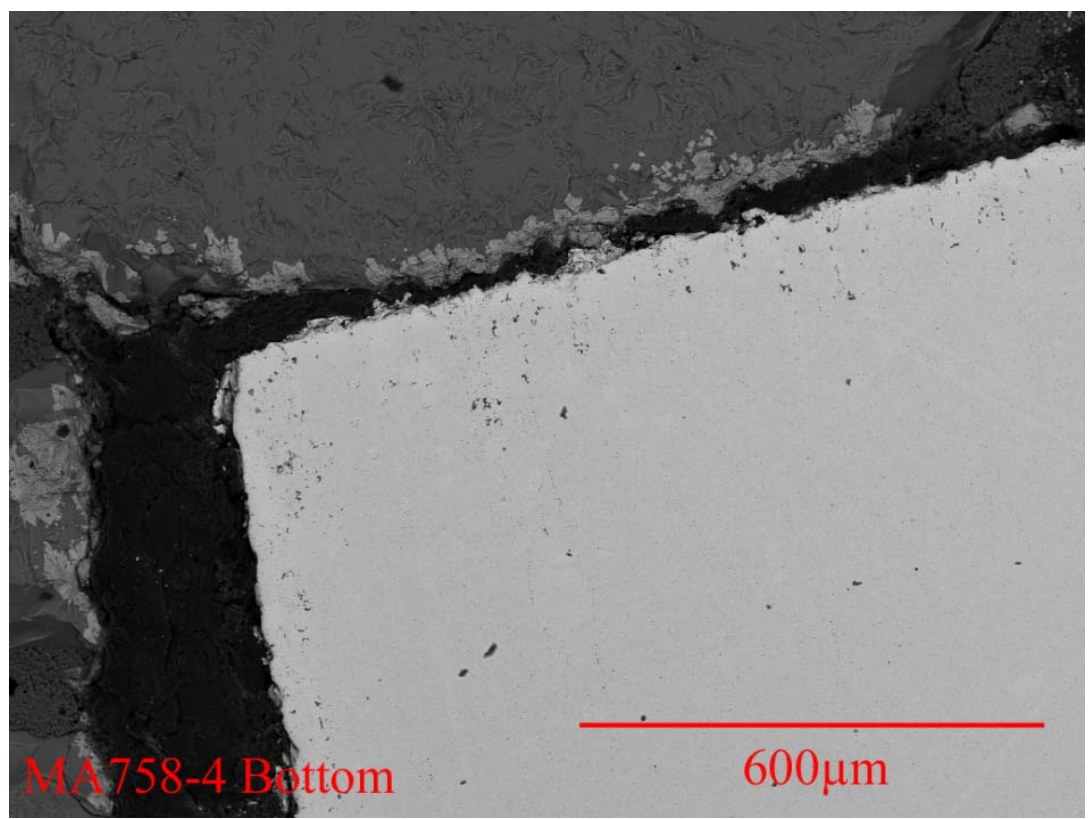

Figure 3.5(d). SEM images of MA758 test coupon after 7-day standard metal corrosion test in $\mathrm{HLW}$-NG-Fe2 glass melt at $1150^{\circ} \mathrm{C}$ showing the tip of the test coupon. Light grey irregular aggregates are the metal oxide scale detached from the test coupon. 


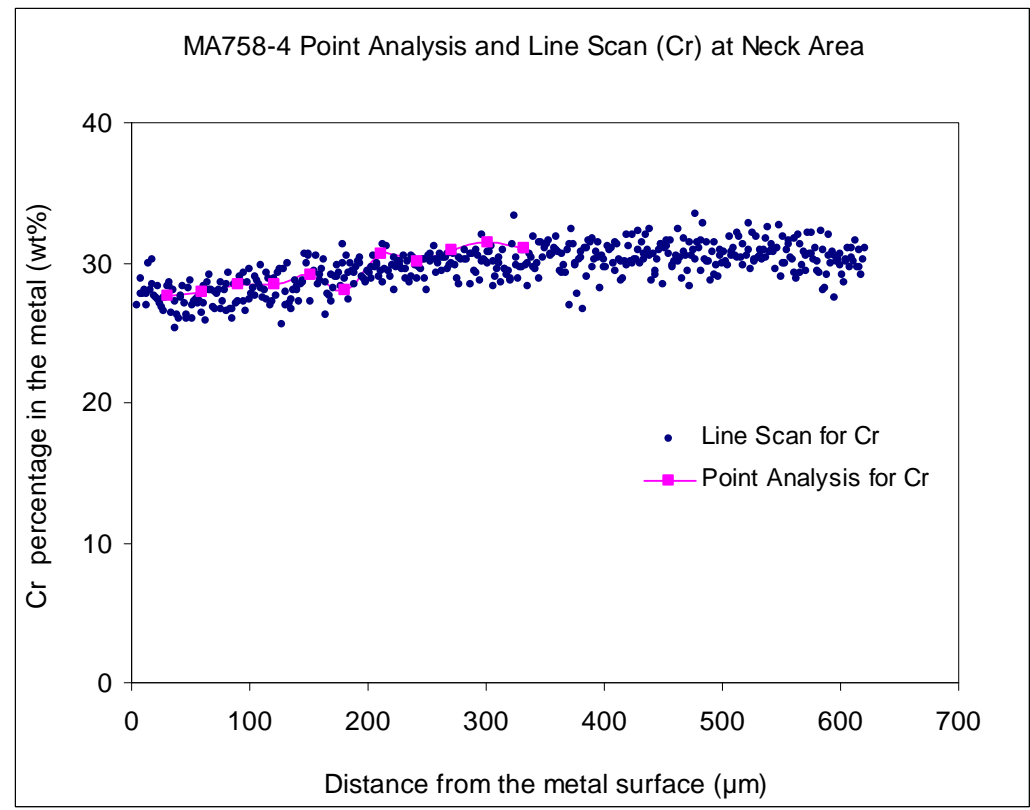

a) MA758 in neck area

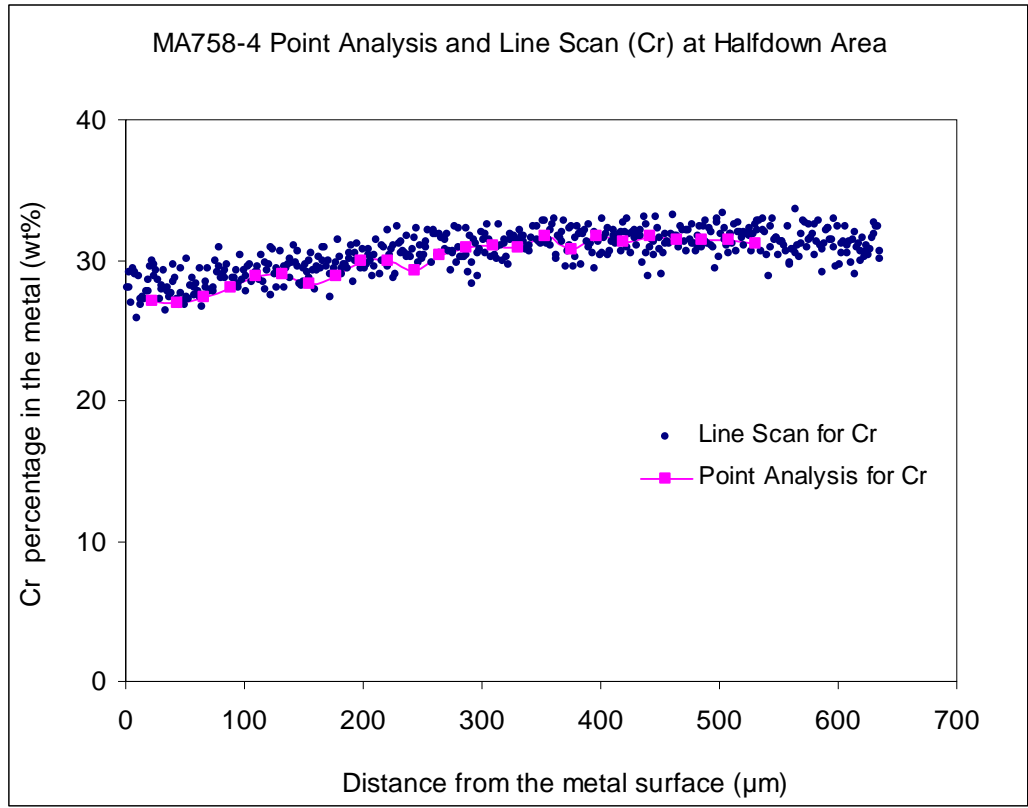

b) MA758 in half-down area

Figure 3.6. Concentration profiles of $\mathrm{Cr}$ in MA758 test coupon by SEM/EDS after 7-day standard metal corrosion test in HLW-NG-Fe2 at $1150^{\circ} \mathrm{C}$. 


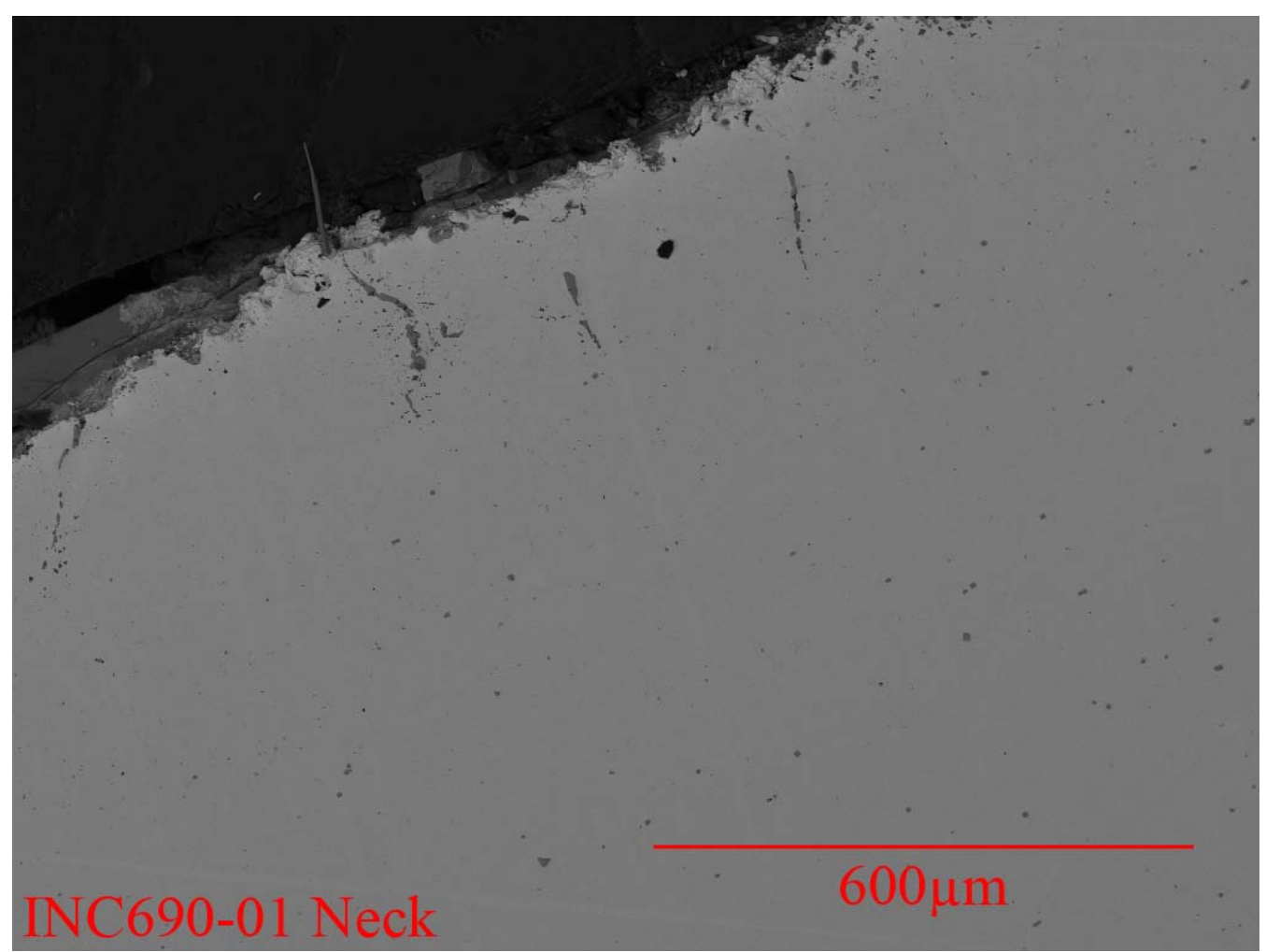

Figure 3.7(a). SEM image of Inconel 690 test coupon after 7-day standard metal corrosion test (open to air) in $\mathrm{HLWS}-09$ at $1150^{\circ} \mathrm{C}$ showing the neck area.

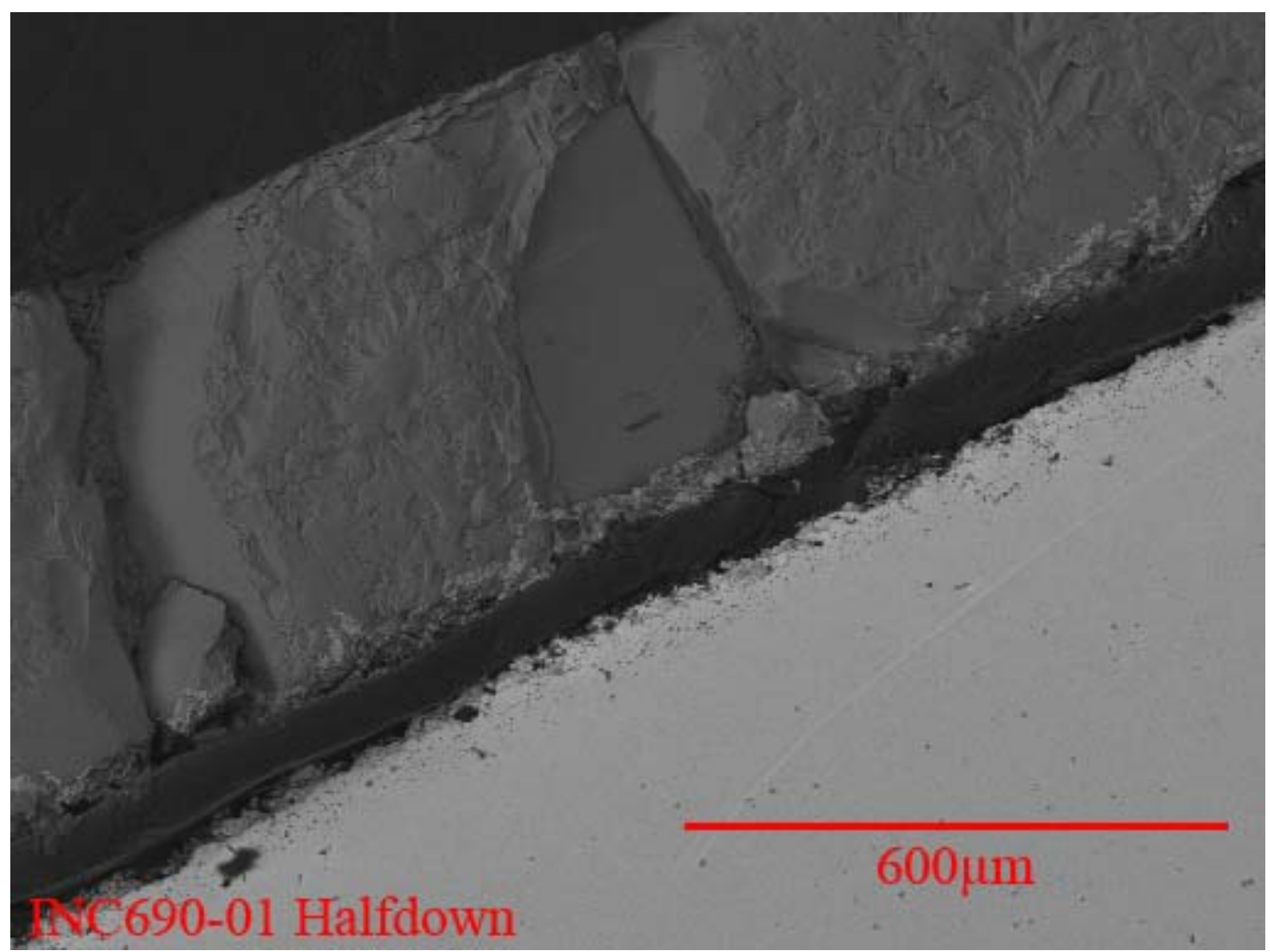

Figure 3.7(b). SEM image of Inconel 690 test coupon after 7-day standard metal corrosion test (open to air) in $\mathrm{HLWS}-09$ at $1150^{\circ} \mathrm{C}$ showing half-down area. 


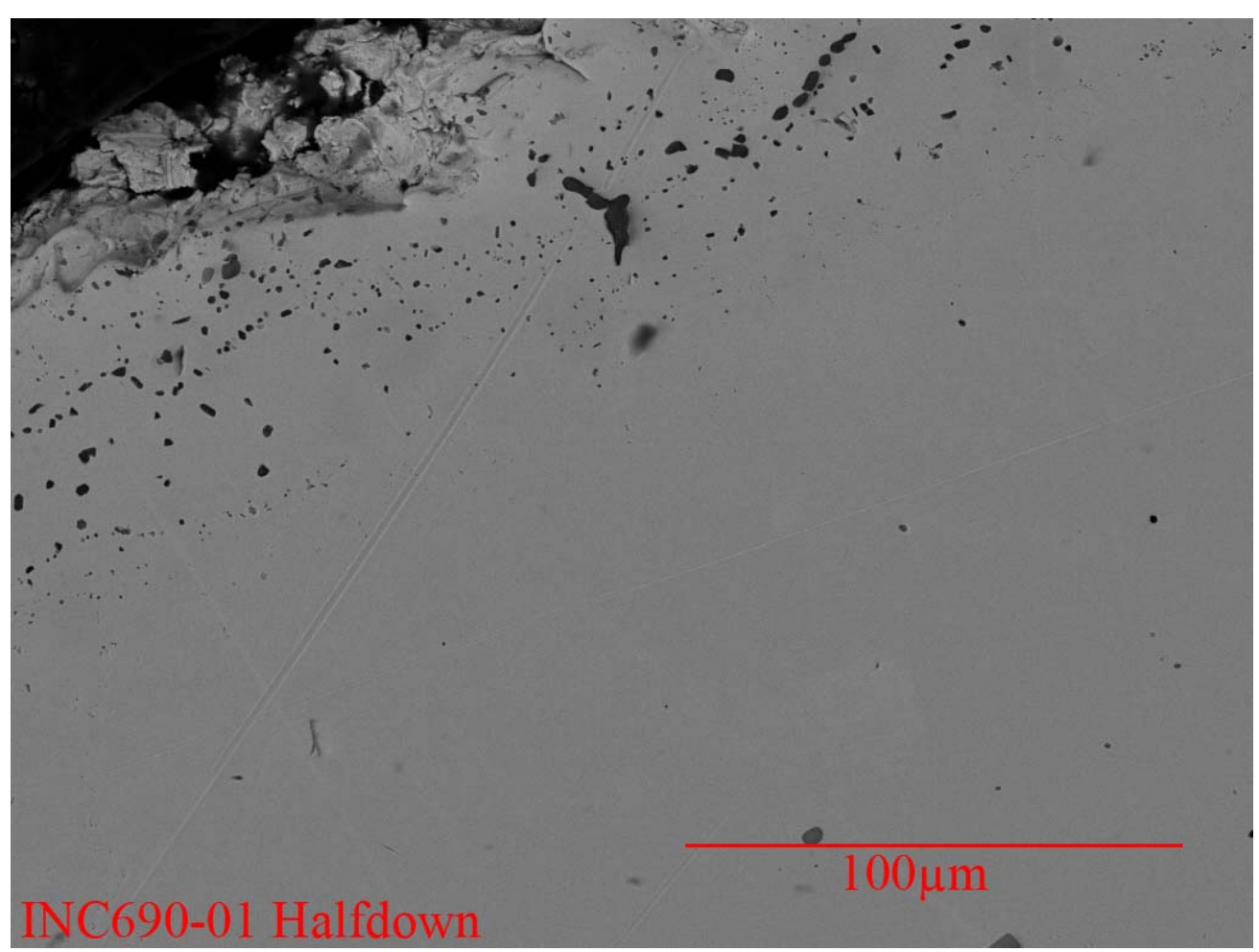

Figure 3.7(c). SEM image of Inconel 690 test coupon after 7-day standard metal corrosion test (open to air) in $\mathrm{HLWS}-09$ at $1150^{\circ} \mathrm{C}$ showing close up view of half-down area.

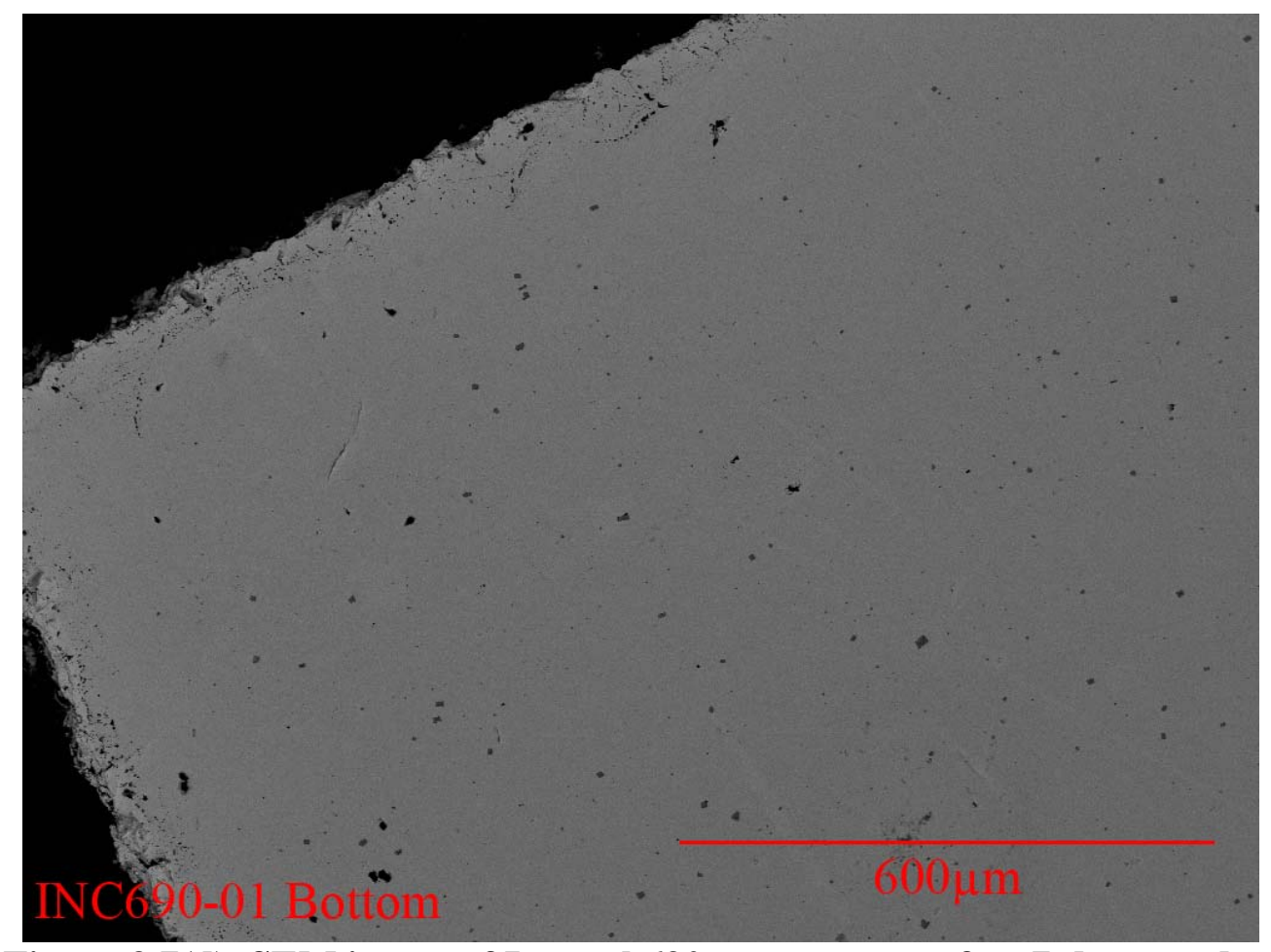

Figure 3.7(d). SEM image of Inconel 690 test coupons after 7-day standard metal corrosion test (open to air) in HLWS-09 at $1150^{\circ} \mathrm{C}$ showing tip of test coupon. 


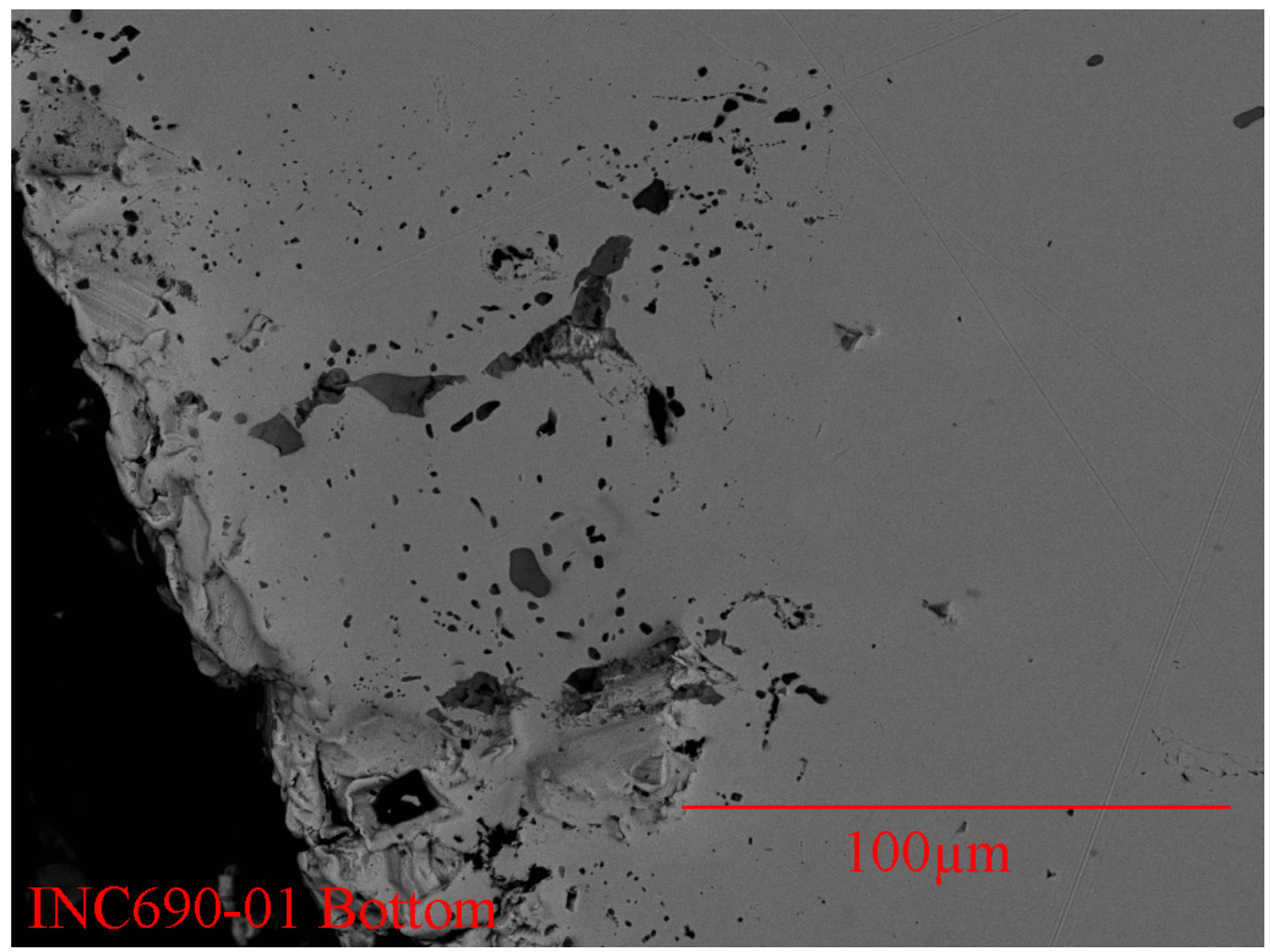

Figure 3.7(e). SEM image of Inconel 690 test coupon after 7-day standard metal corrosion test (open to air) in HLWS-09 at $1150^{\circ} \mathrm{C}$ showing close up view of tip of test coupon. Note the development of oxide along the grain boundaries (dark grey areas within metal). 


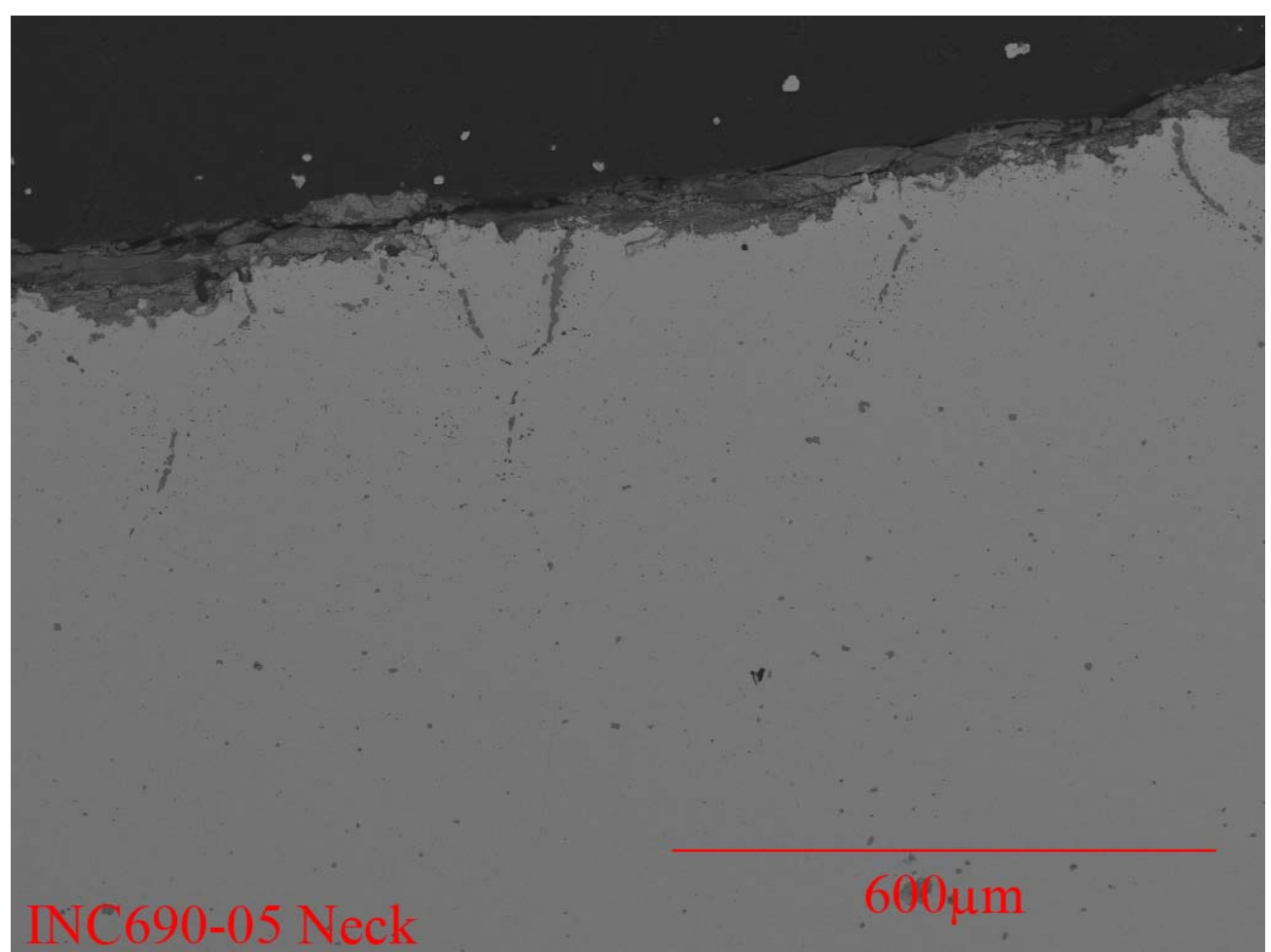

Figure 3.8(a). SEM image of Inconel 690 after 7-day sealed metal corrosion test in HLWS-09 at $1150^{\circ} \mathrm{C}$ showing neck area (sealed crucible test).

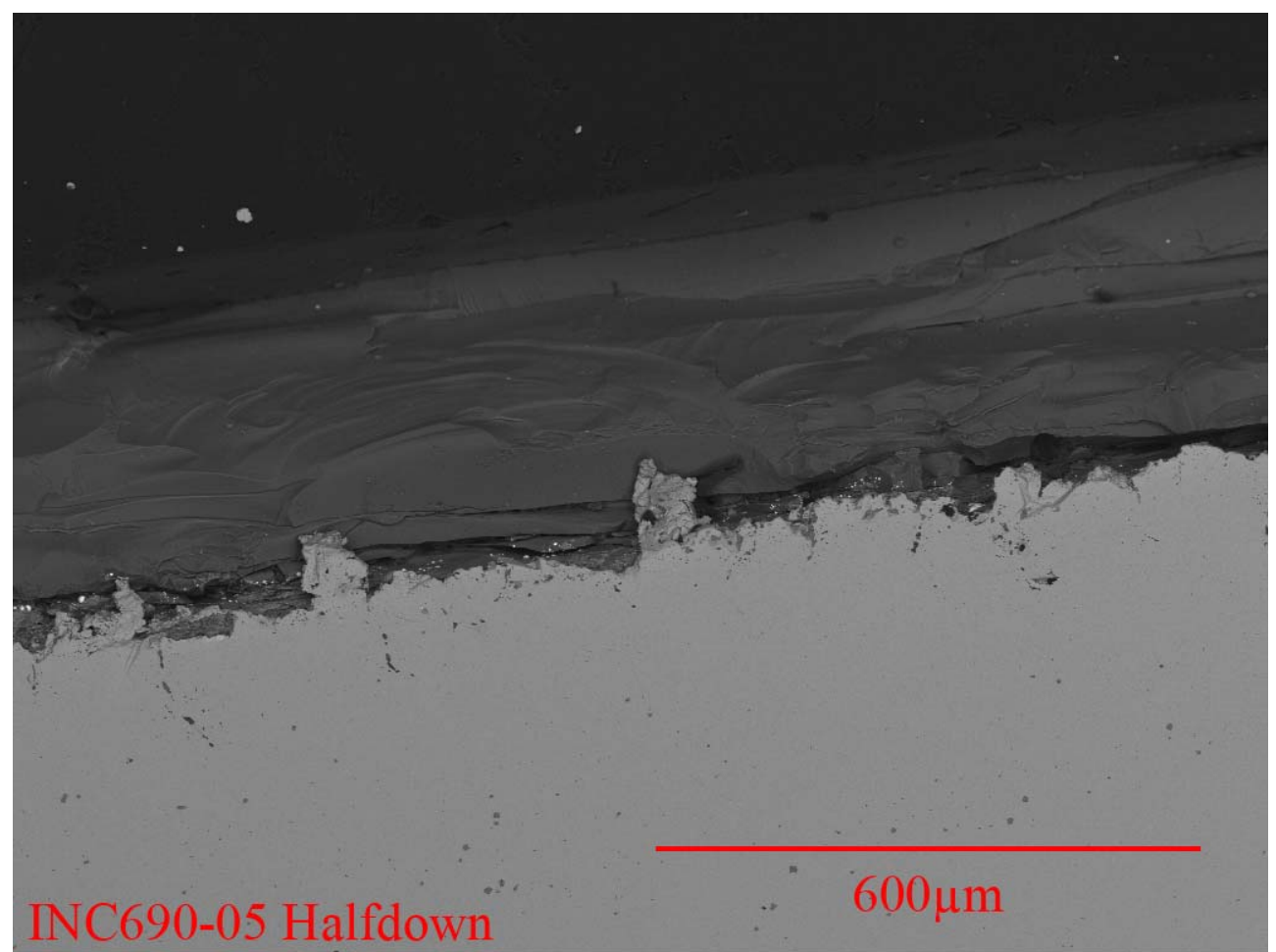

Figure 3.8(b). SEM image of Inconel 690 after 7-day sealed metal corrosion test in HLWS-09 at $1150^{\circ} \mathrm{C}$ showing half-down area (sealed crucible test). 


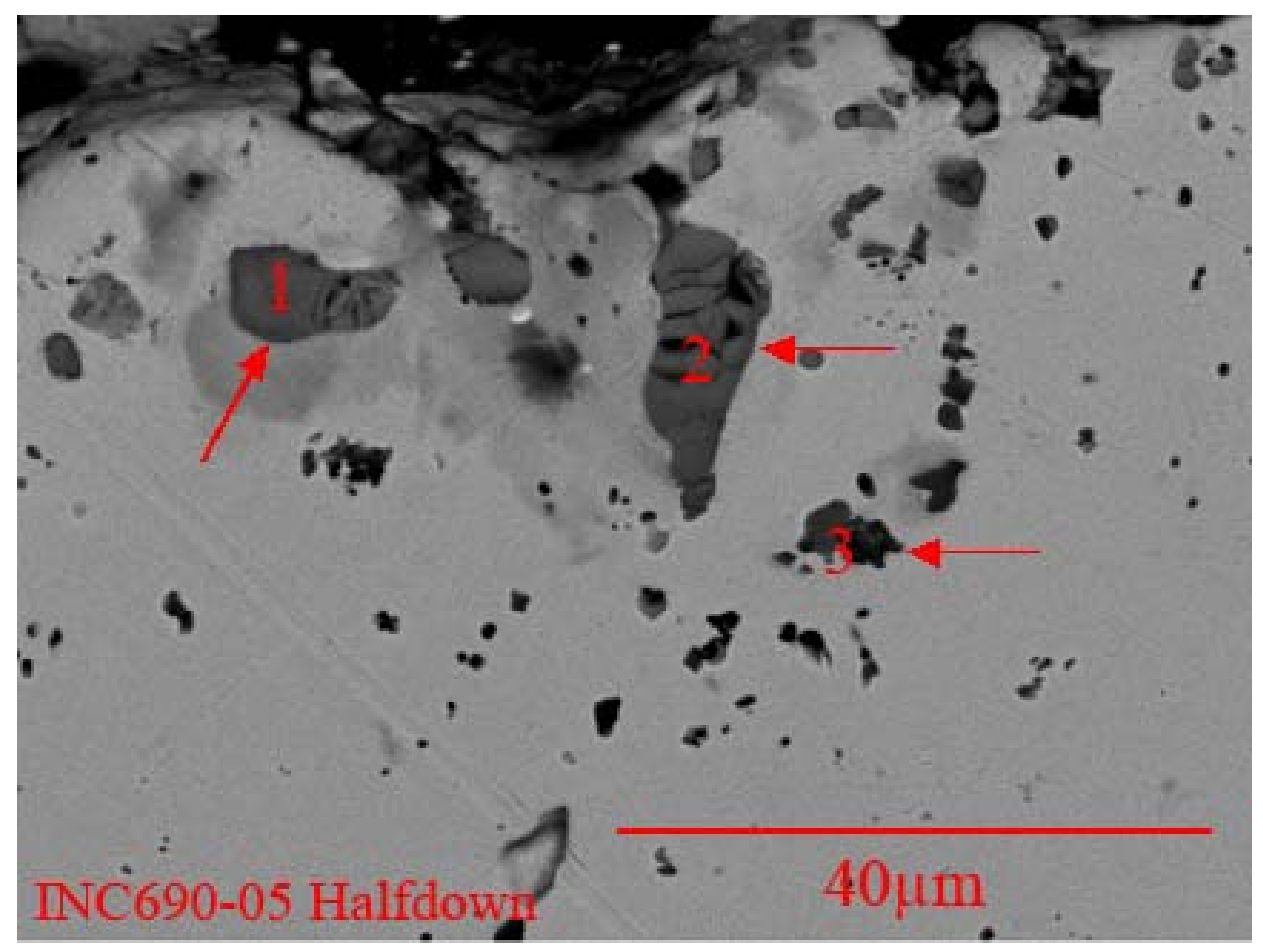

Figure 3.8(c). SEM image of Inconel 690 after 7-day sealed metal corrosion test in HLWS-09 at $1150^{\circ} \mathrm{C}$ showing close up view of half-down area. Dark grey areas $(1,2)$ are chromium oxide and black patch (3) is oxide rich in titanium.

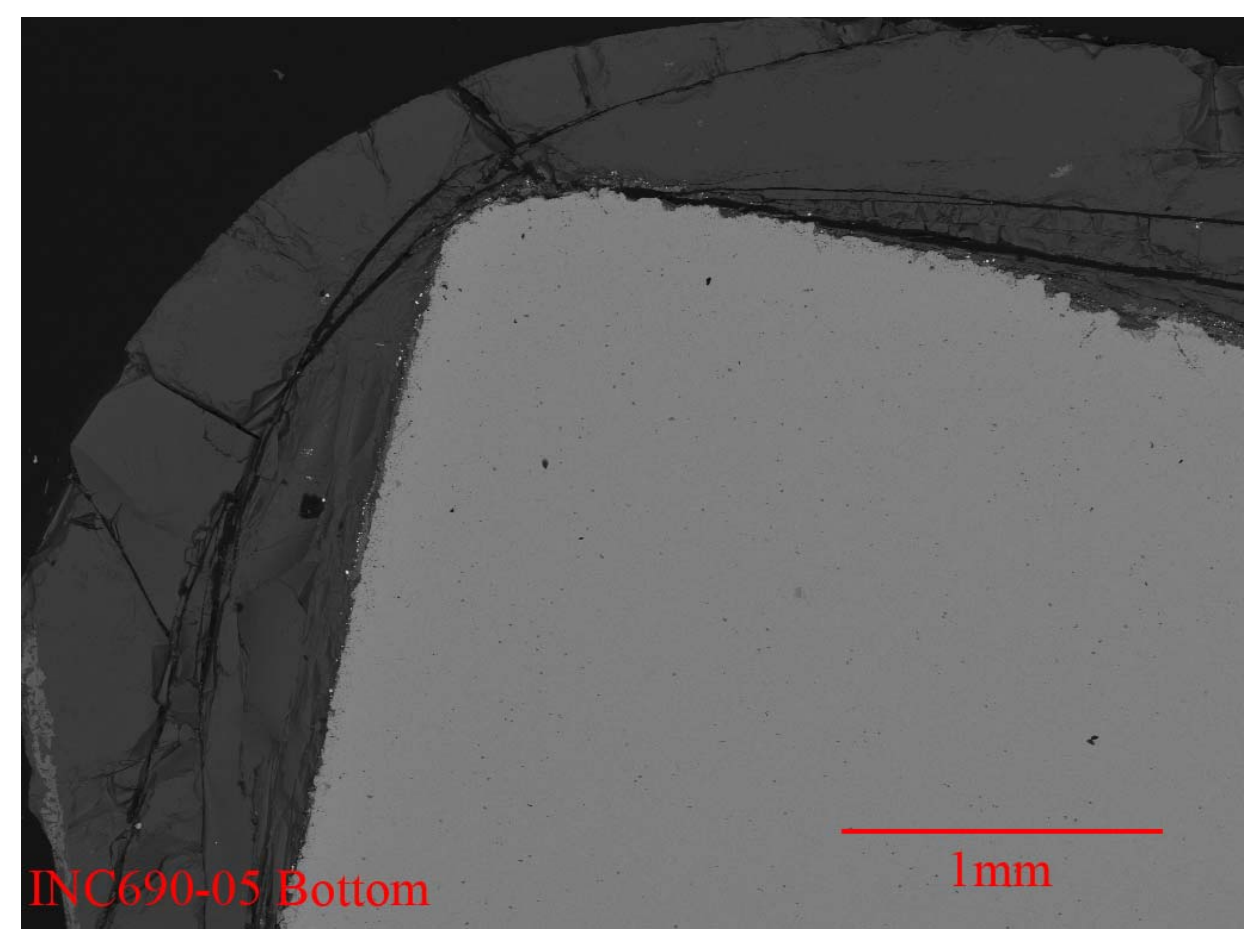

Figure 3.8(d). SEM image of Inconel 690 after 7-day sealed metal corrosion test in HLWS-09 at $1150^{\circ} \mathrm{C}$ showing the tip of the metal coupon (sealed crucible test). 


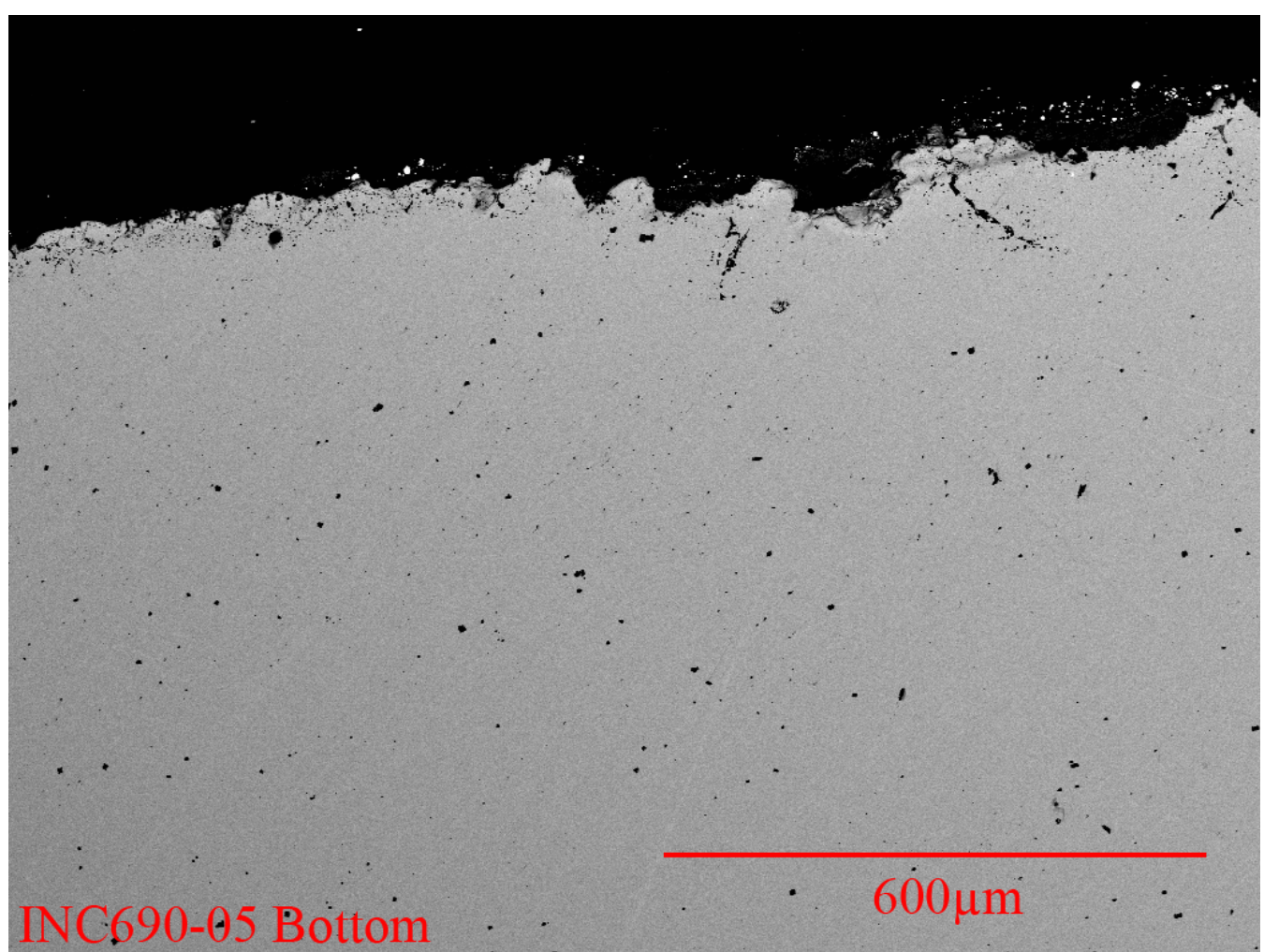

Figure 3.8(e). SEM image of Inconel 690 after 7-day sealed metal corrosion test in HLWS-09 at $1150^{\circ} \mathrm{C}$ showing a close up view of the tip of the metal coupon (sealed crucible test). 


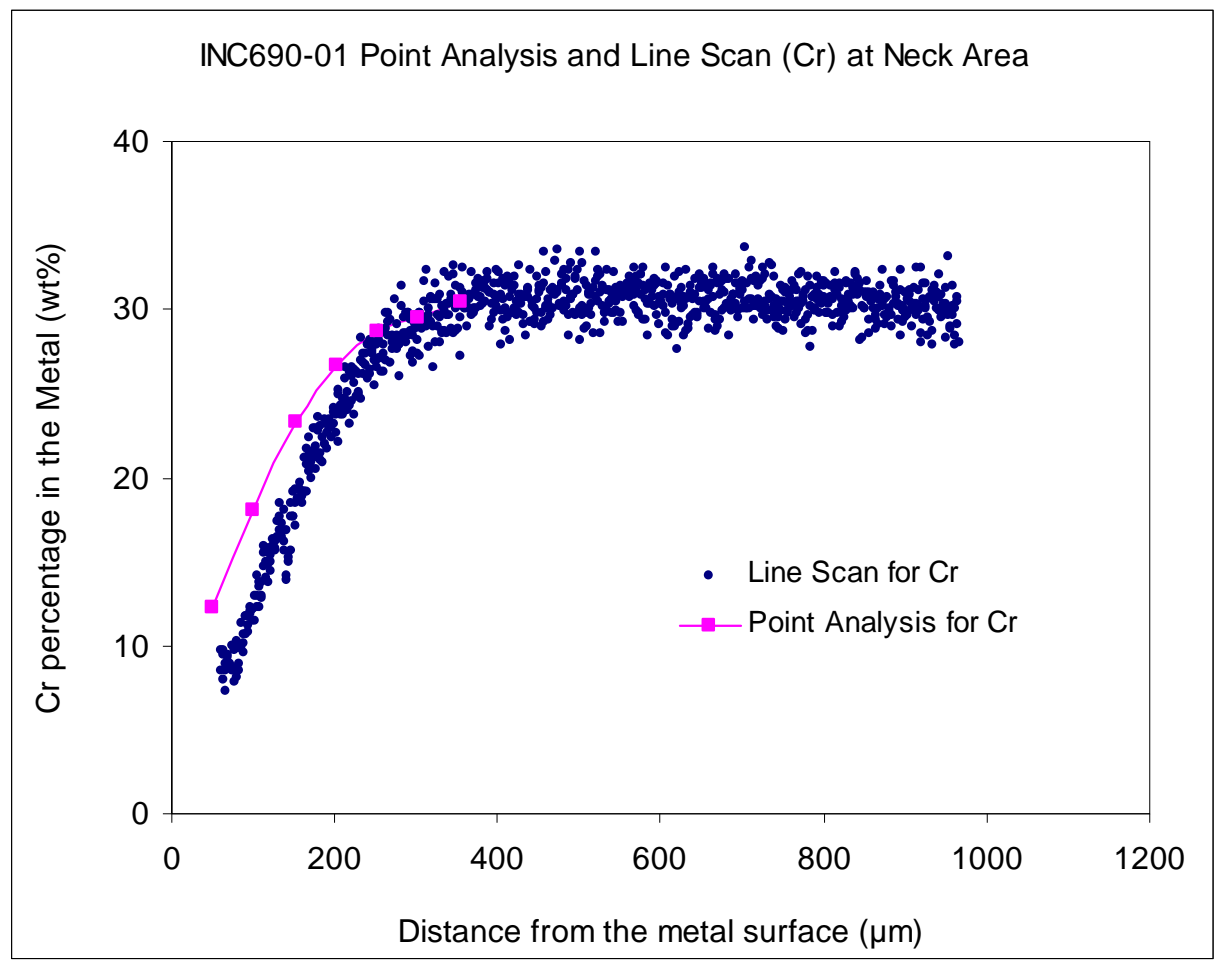

a) Inconel 690 in neck area (7-day standard open crucible test)

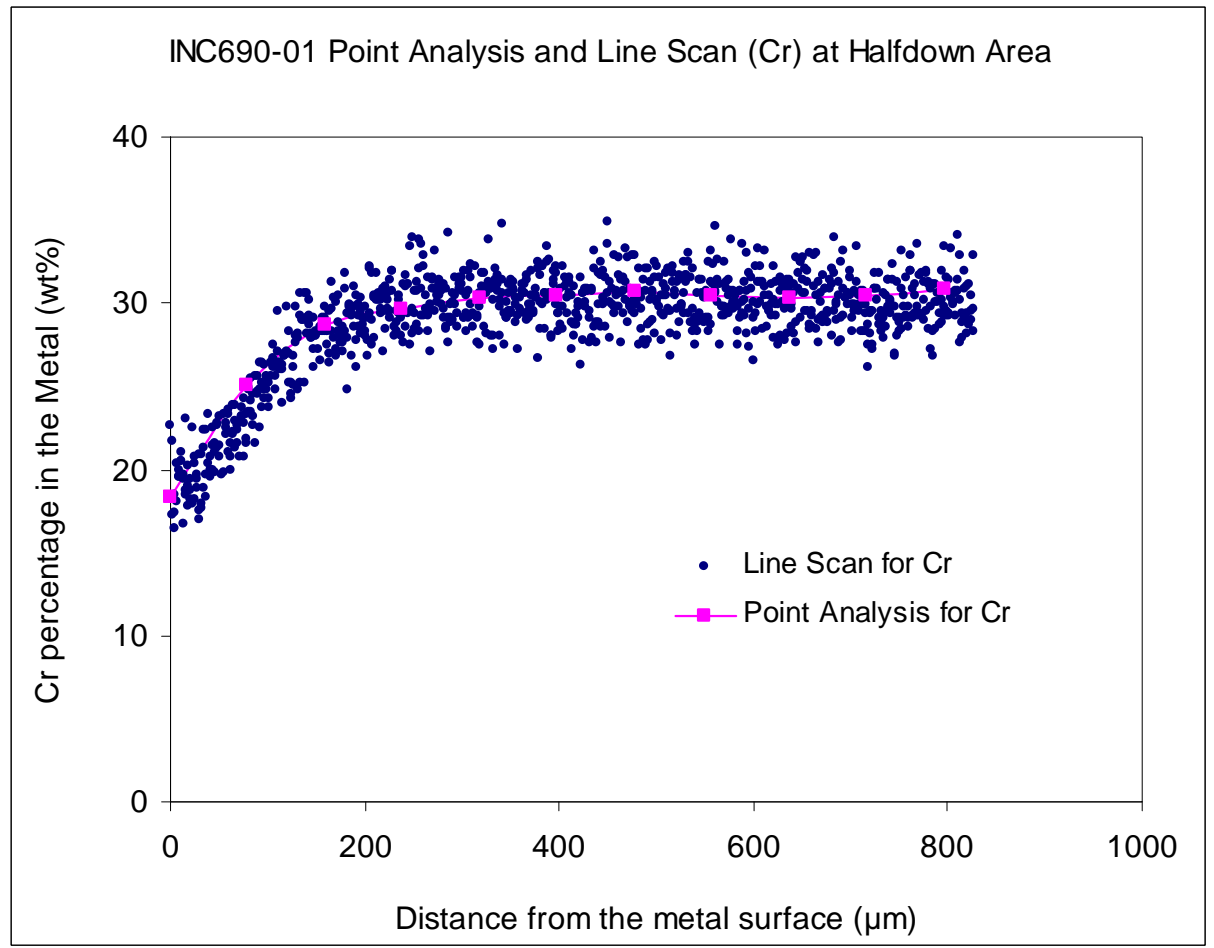

b) Inconel 690 in half-down area (7-day standard open crucible test)

Figure 3.9. Concentration profiles of $\mathrm{Cr}$ in Inconel 690 after a 7-day corrosion test in HLWS-09. 


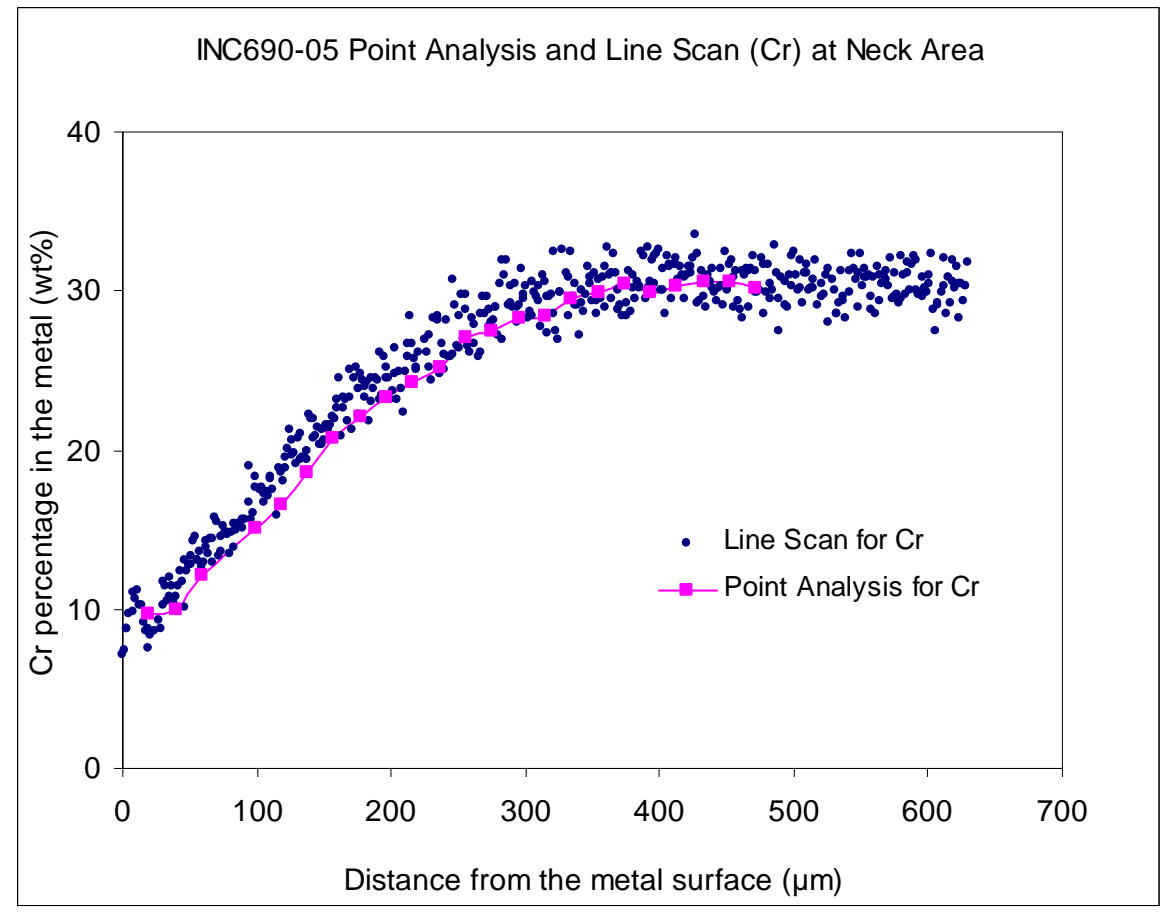

c) Inconel 690 in neck area (7-day sealed crucible test)

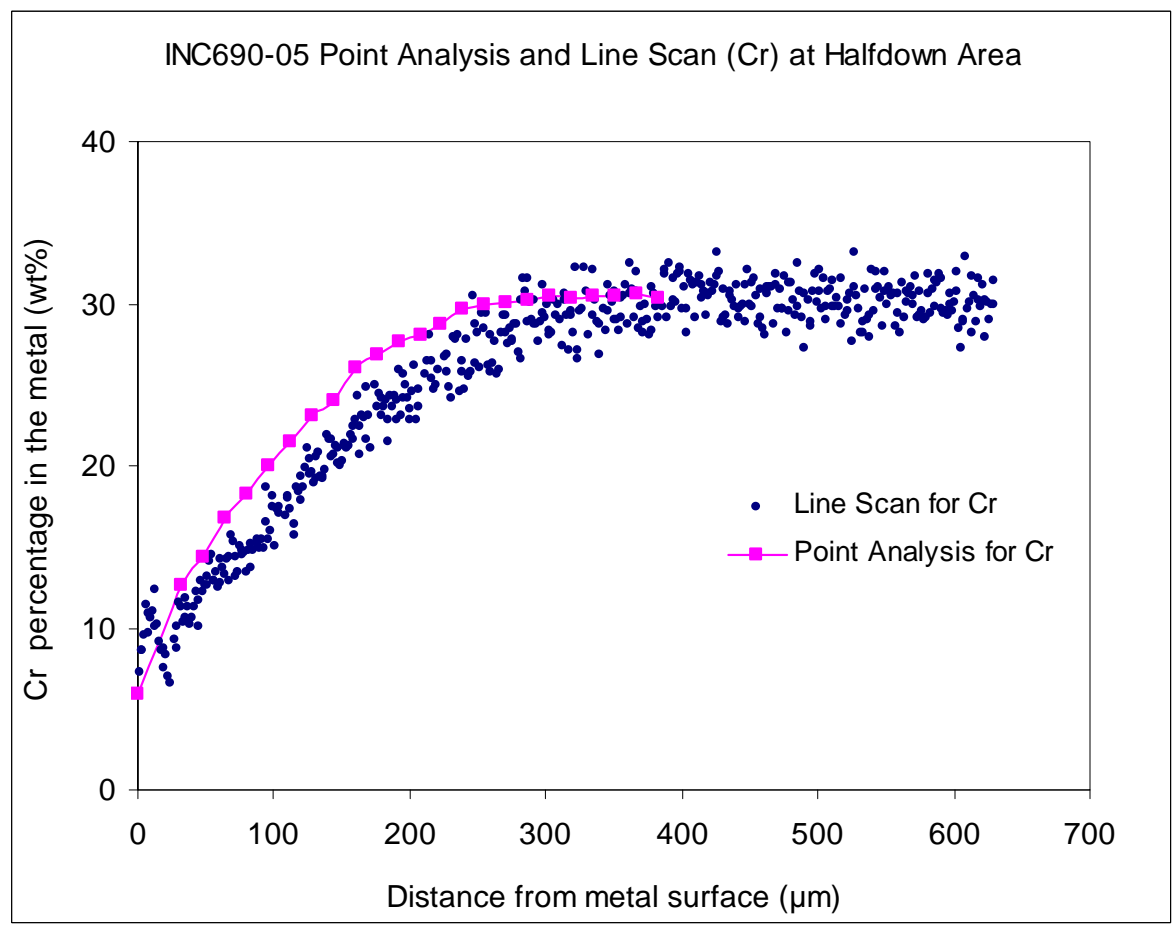

d) Inconel 690 in half-down area (7-day sealed crucible test)

Figure 3.9. Concentration profiles of $\mathrm{Cr}$ in Inconel 690 after 7-day corrosion test in HLWS-09 (continued). 


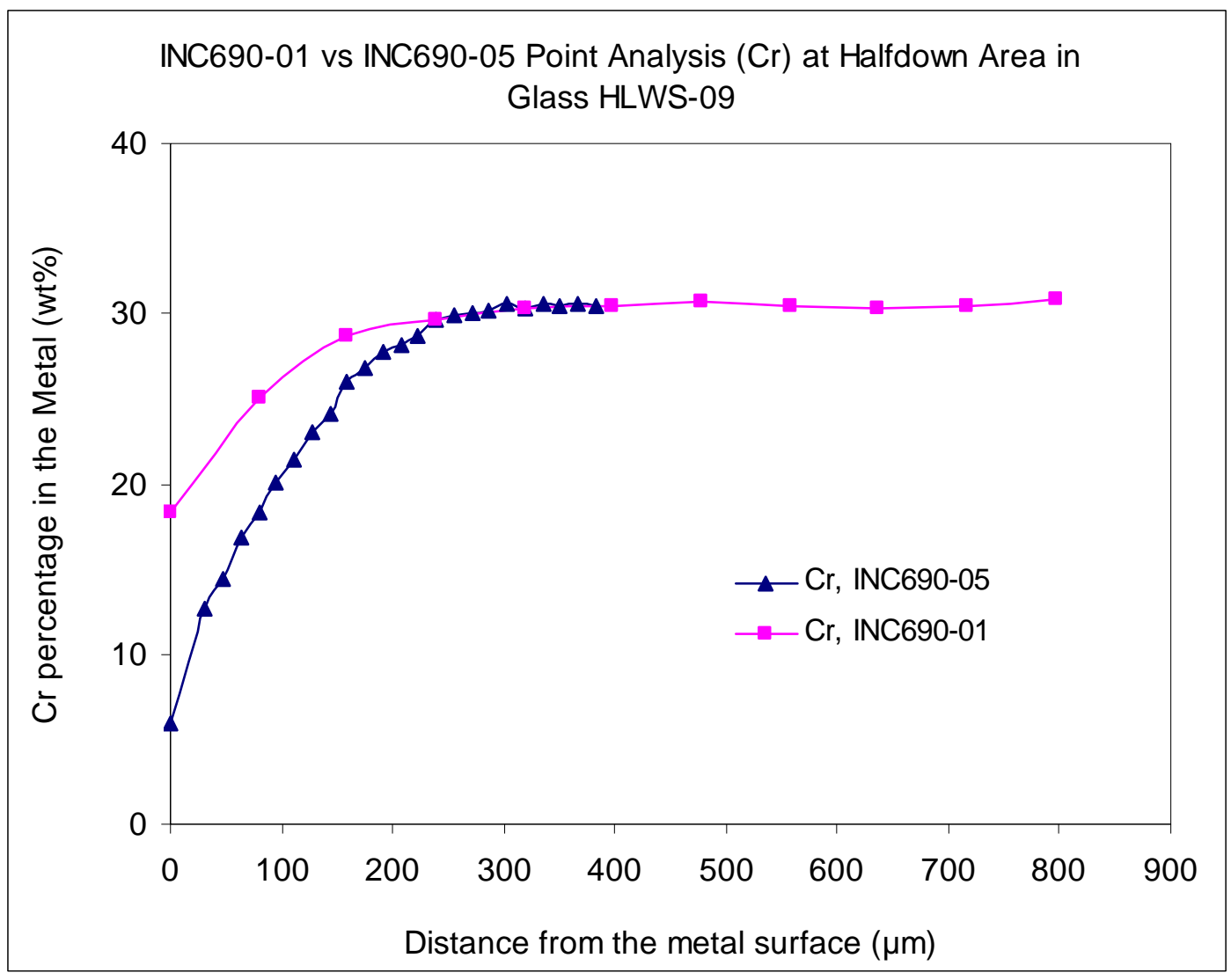

Figure 3.10. SEM/EDS analysis of $\mathrm{Cr}$ in Inconel 690 after 7-day corrosion test in HLWS-09 in standard open crucible condition (filled magenta squares) and in sealed crucible condition (filled black triangles). 


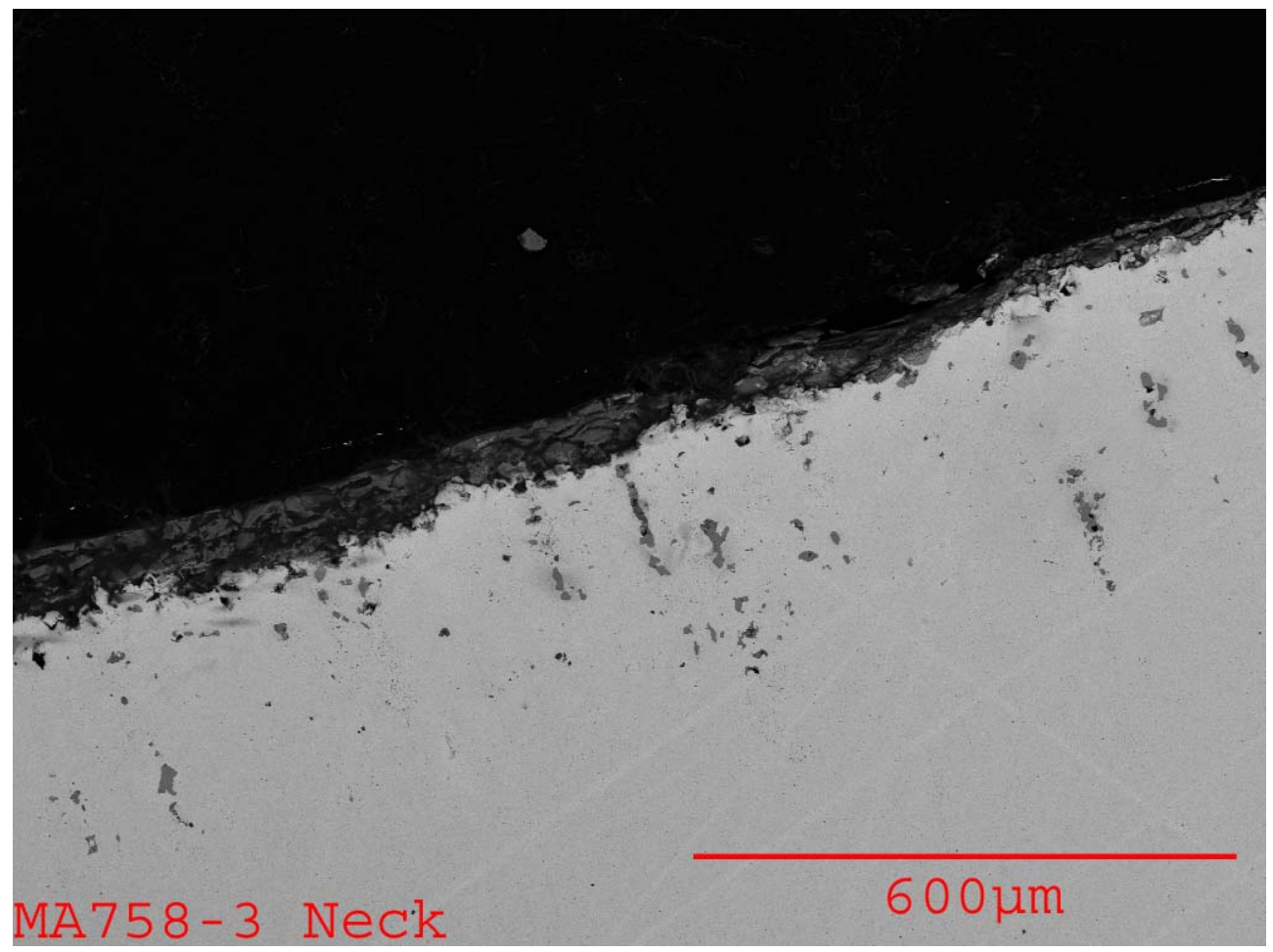

Figure 3.11(a). SEM image of MA758 after 7-day standard open crucible corrosion test in HLWS-09 at $1150^{\circ} \mathrm{C}$ showing the neck area.

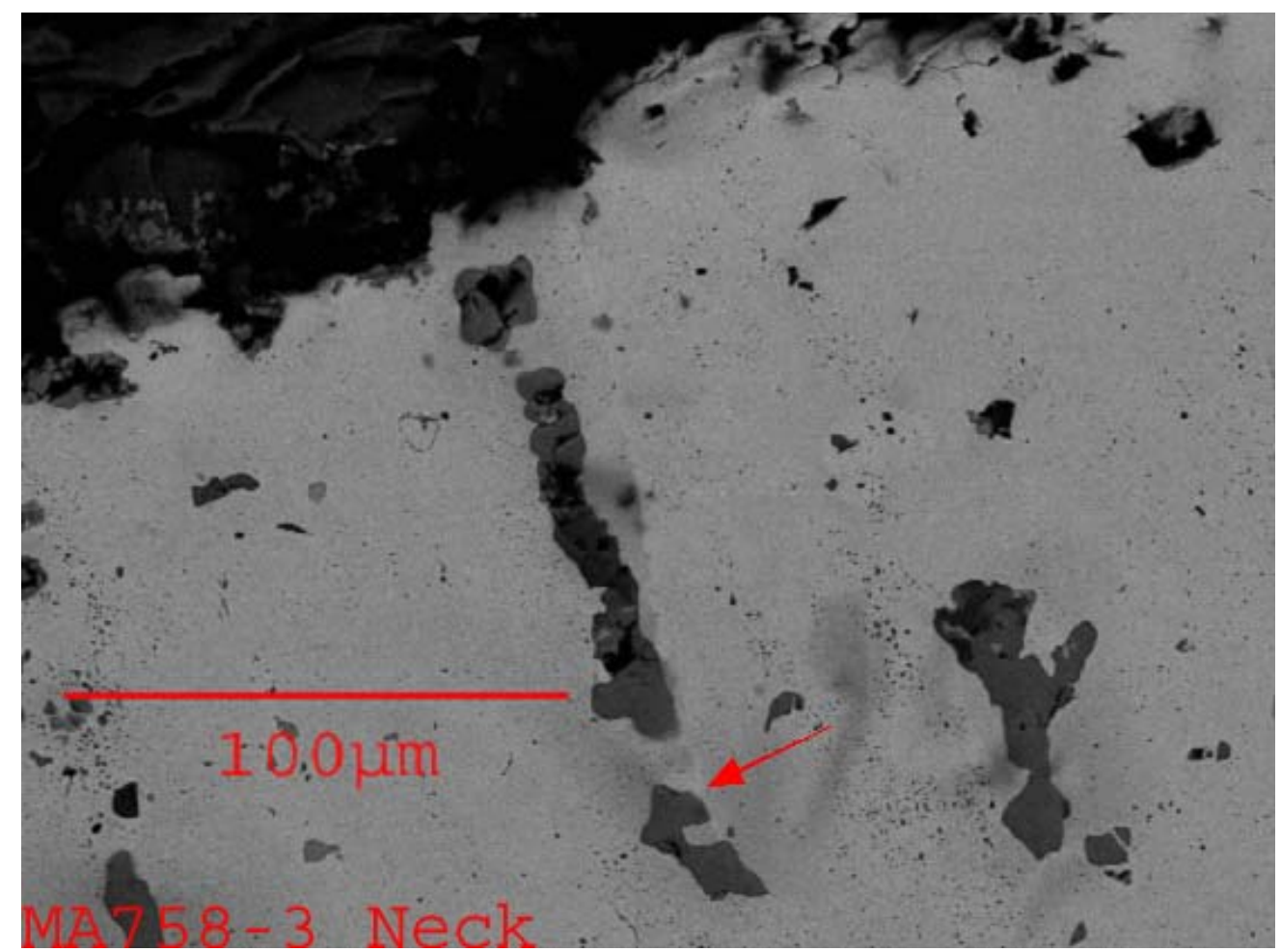

Figure 3.11(b). SEM image of MA758 after 7-day standard open crucible corrosion test in HLWS-09 at $1150^{\circ} \mathrm{C}$ showing a close up view of the neck area. The arrow points to Cr oxide with Ti and Al. 


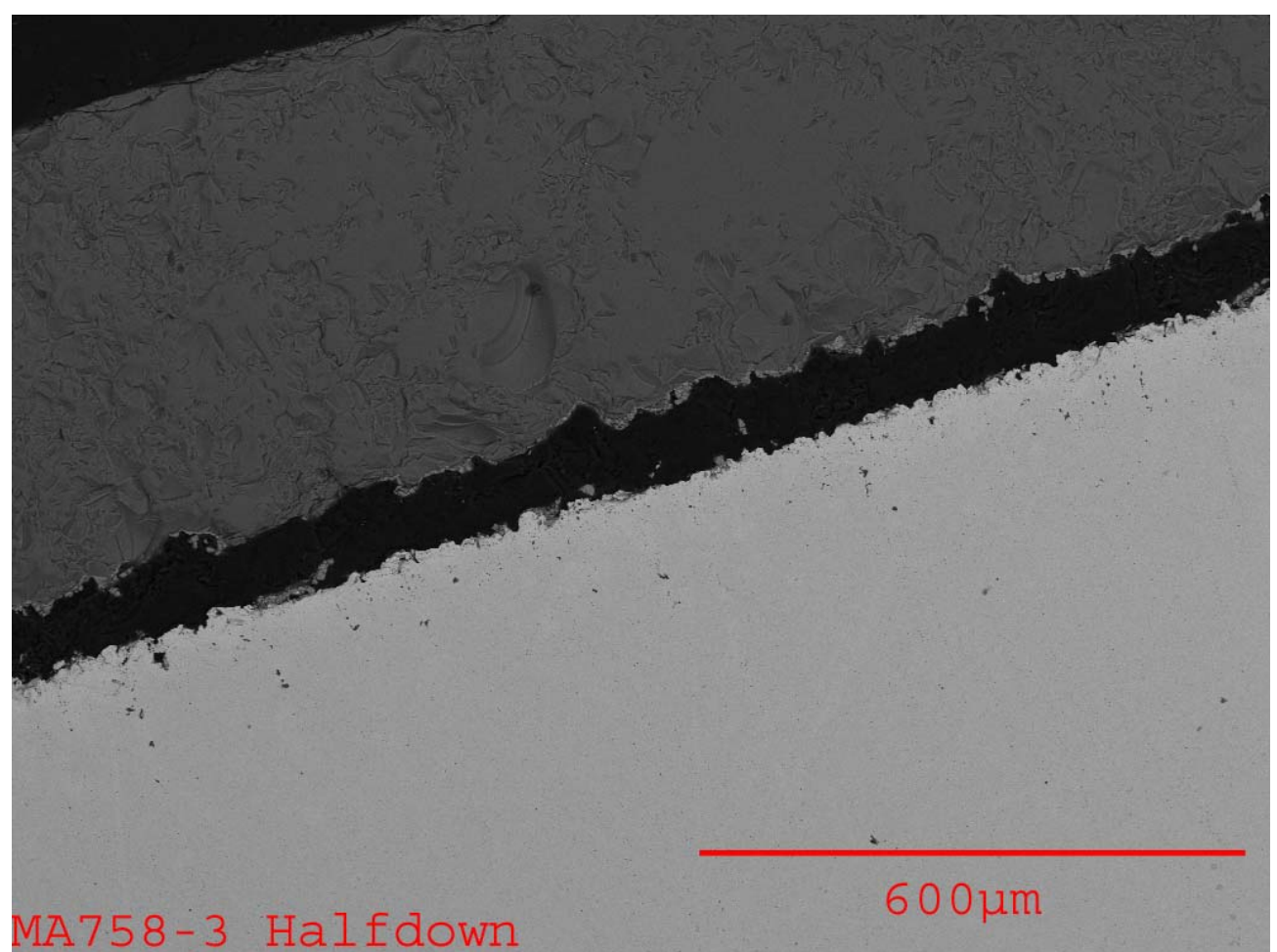

Figure 3.11(c). SEM image of MA758 after 7-day standard open crucible corrosion test in HLWS-09 at $1150^{\circ} \mathrm{C}$ showing the half-down area.

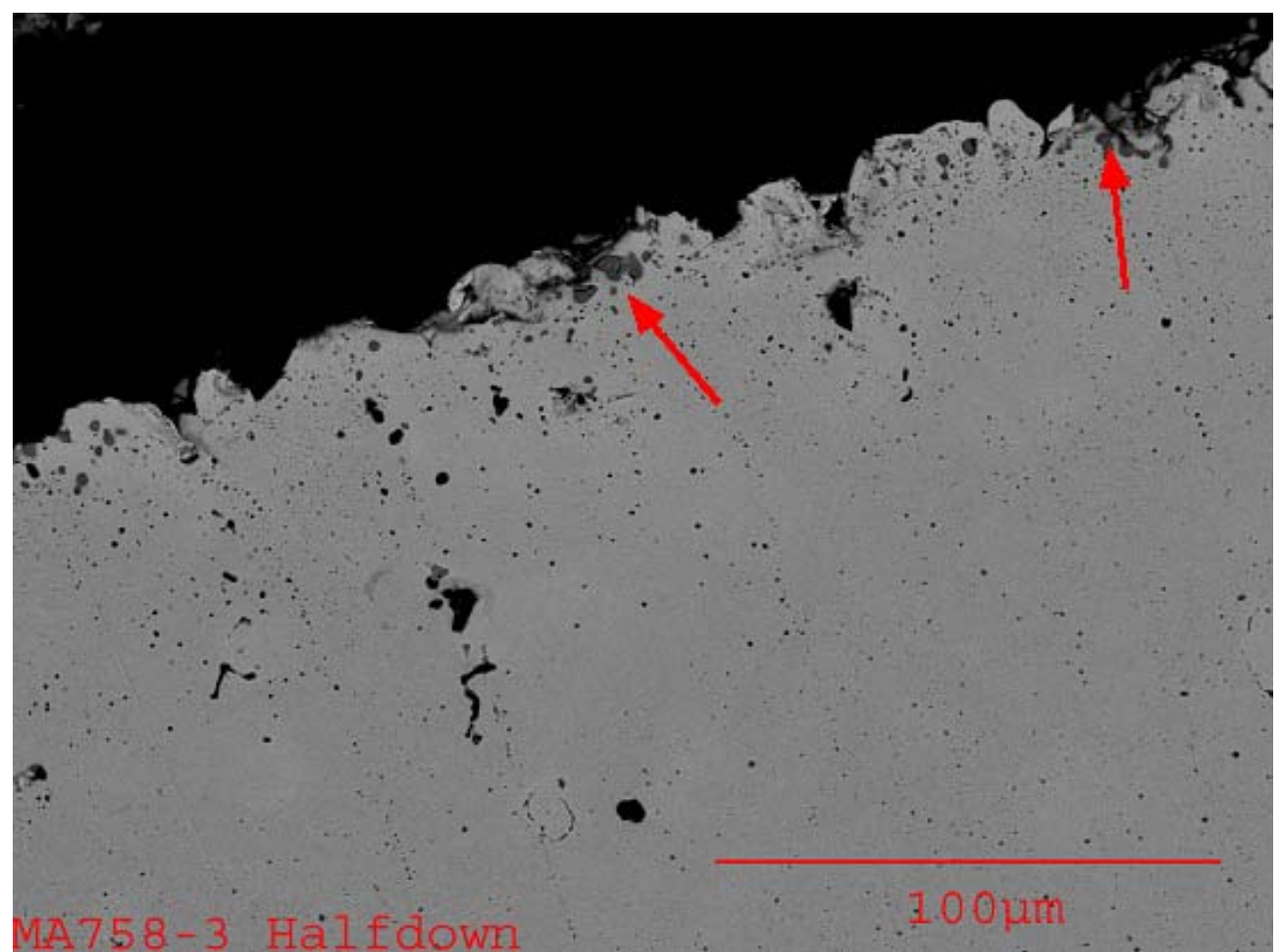

Figure 3.11(d). SEM image of MA758 after 7-day standard open crucible corrosion test in HLWS- 09 at $1150^{\circ} \mathrm{C}$ showing a close up view of the half-down area. The arrows indicate $\mathrm{Cr}_{2} \mathrm{O}_{3}$ near metal surface. 


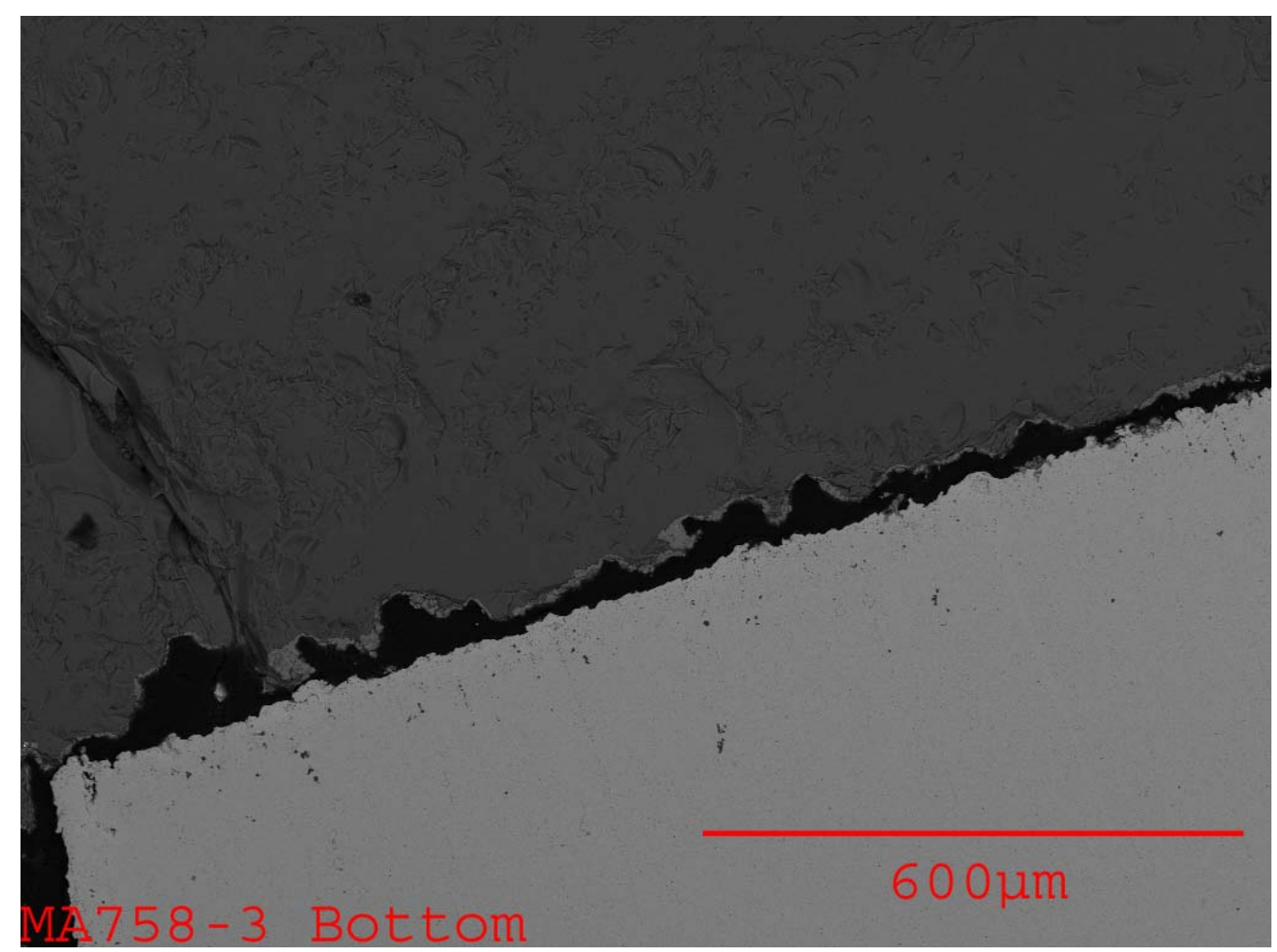

Figure 3.11(e). SEM image of MA758 after 7-day standard open crucible corrosion test in HLWS-09 at $1150^{\circ} \mathrm{C}$ showing the tip of the test coupon. 


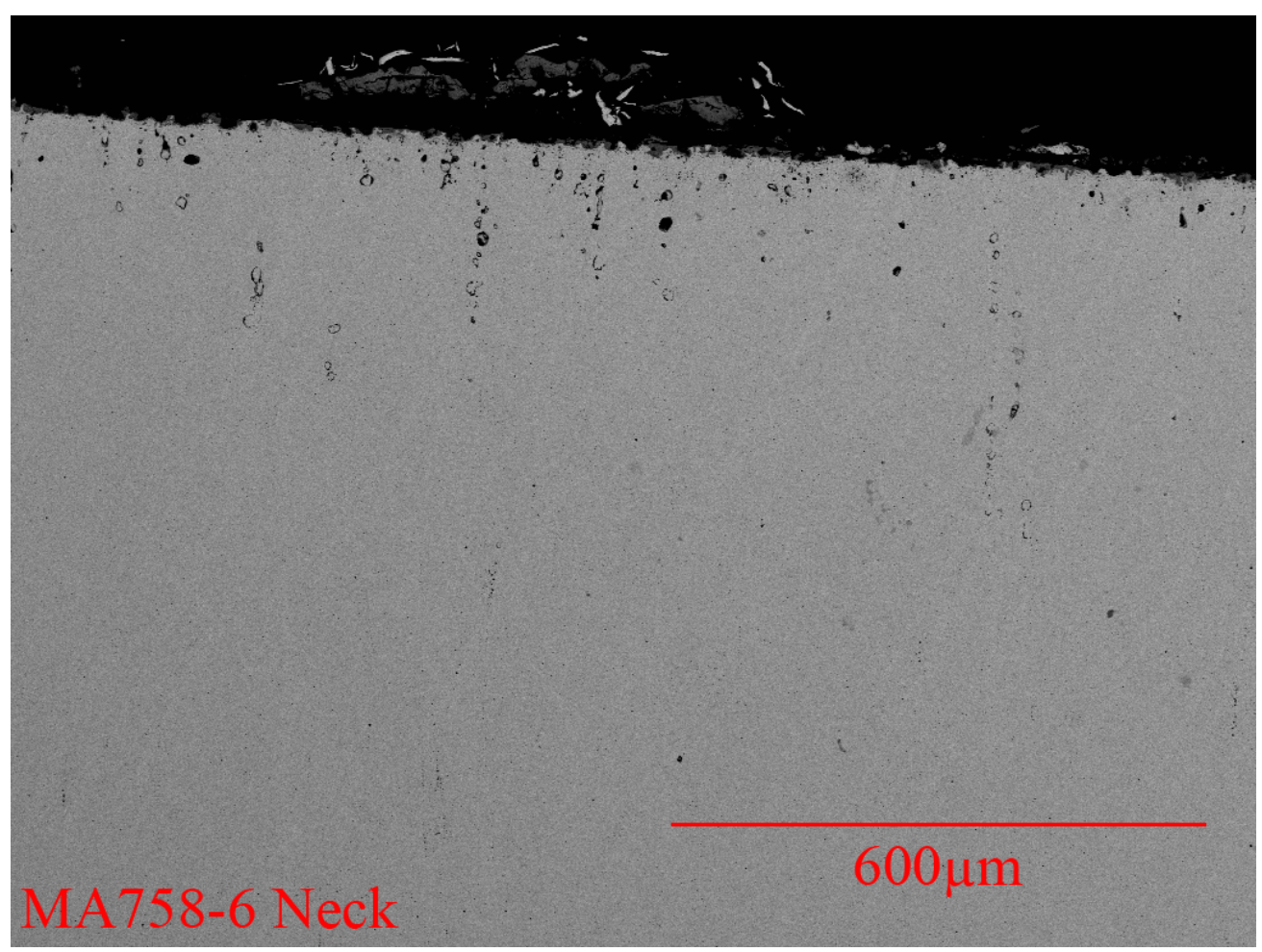

Figure 3.12(a). SEM image of MA758 after 7-day sealed crucible test in HLWS-09 at $1150^{\circ} \mathrm{C}$ showing the neck area.

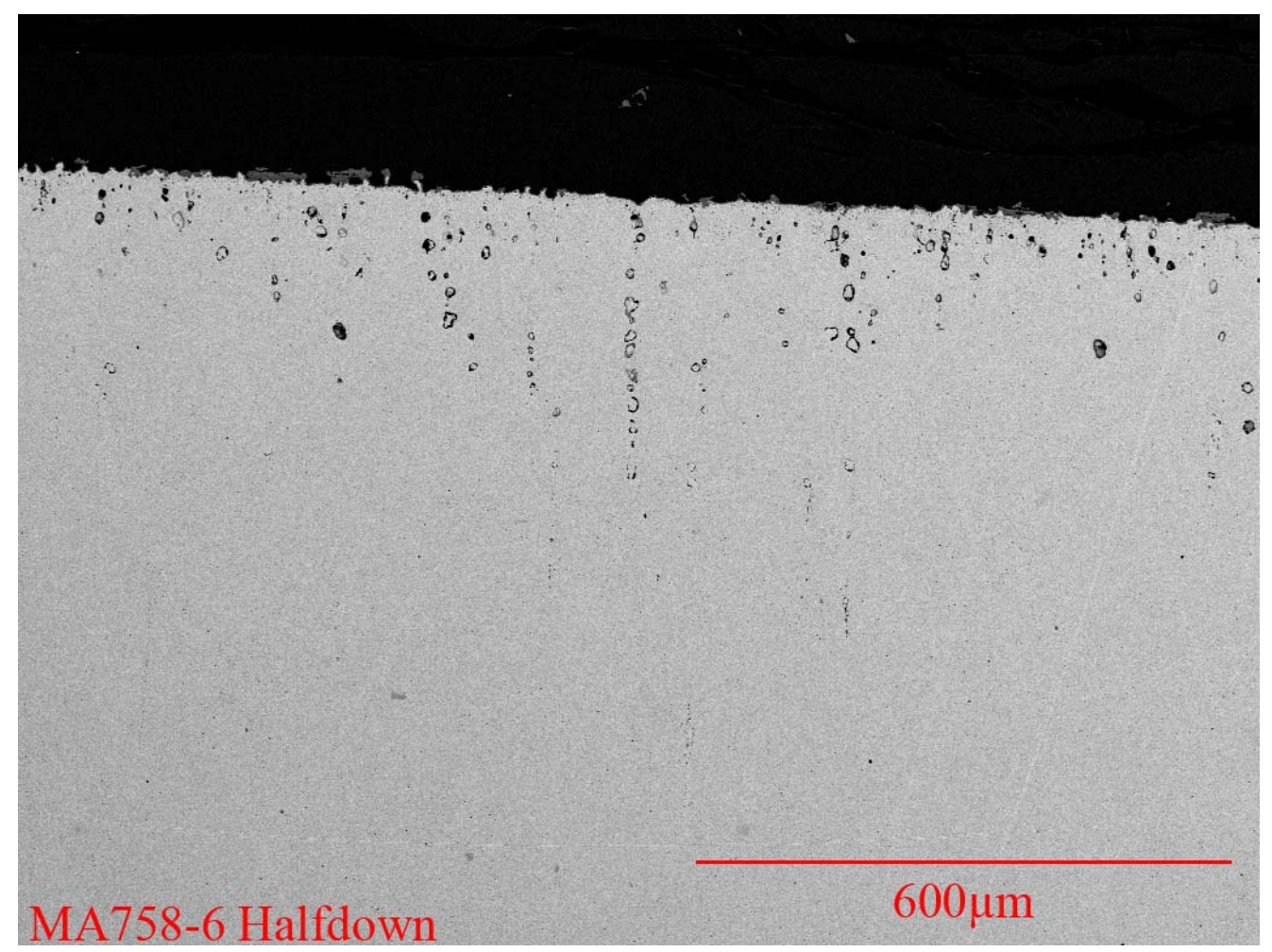

Figure 3.12(b). SEM image of MA758 after 7-day sealed crucible test in HLWS-09 at $1150^{\circ}$ Cshowing the half-down area. 


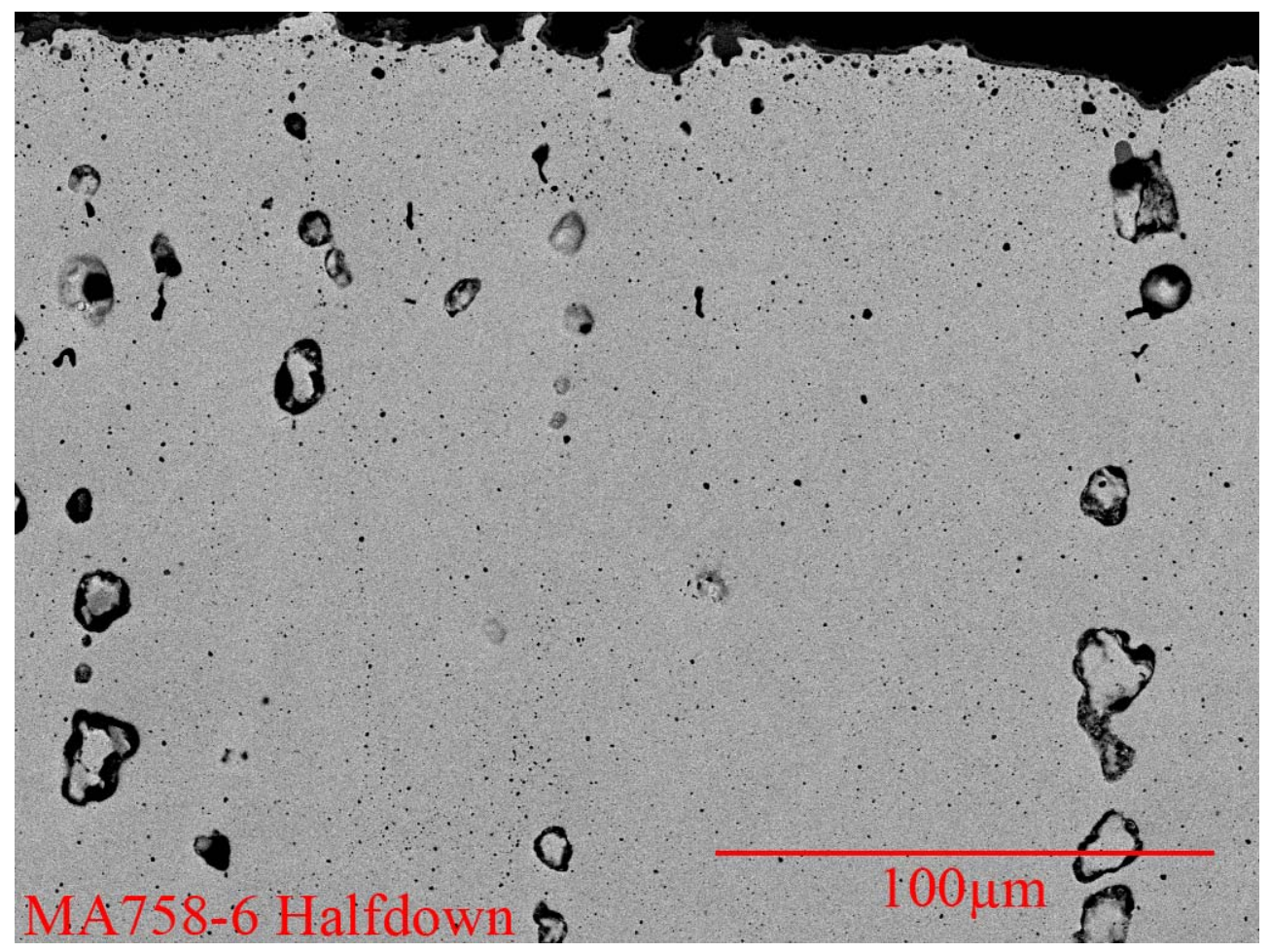

Figure 3.12(c). SEM image of MA758 after 7-day sealed crucible test in HLWS-09 at $1150^{\circ} \mathrm{C}$ showing close up view of the half-down area.

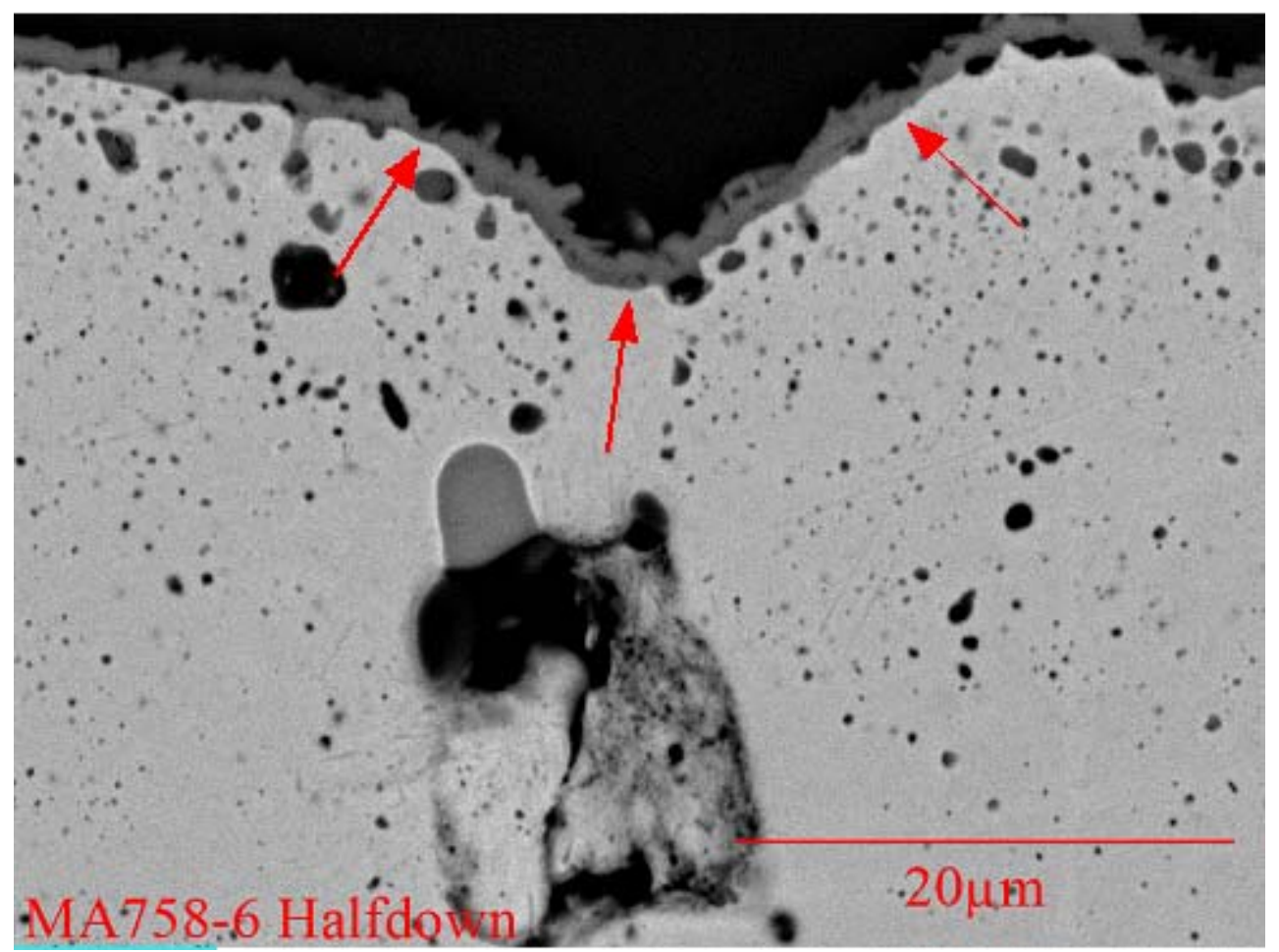

Figure 3.12(d). SEM image of MA758 after 7-day sealed crucible test in HLWS-09 at $1150^{\circ} \mathrm{C}$ showing a detailed view of the half down-area. The arrows point to chromium oxide scale. 


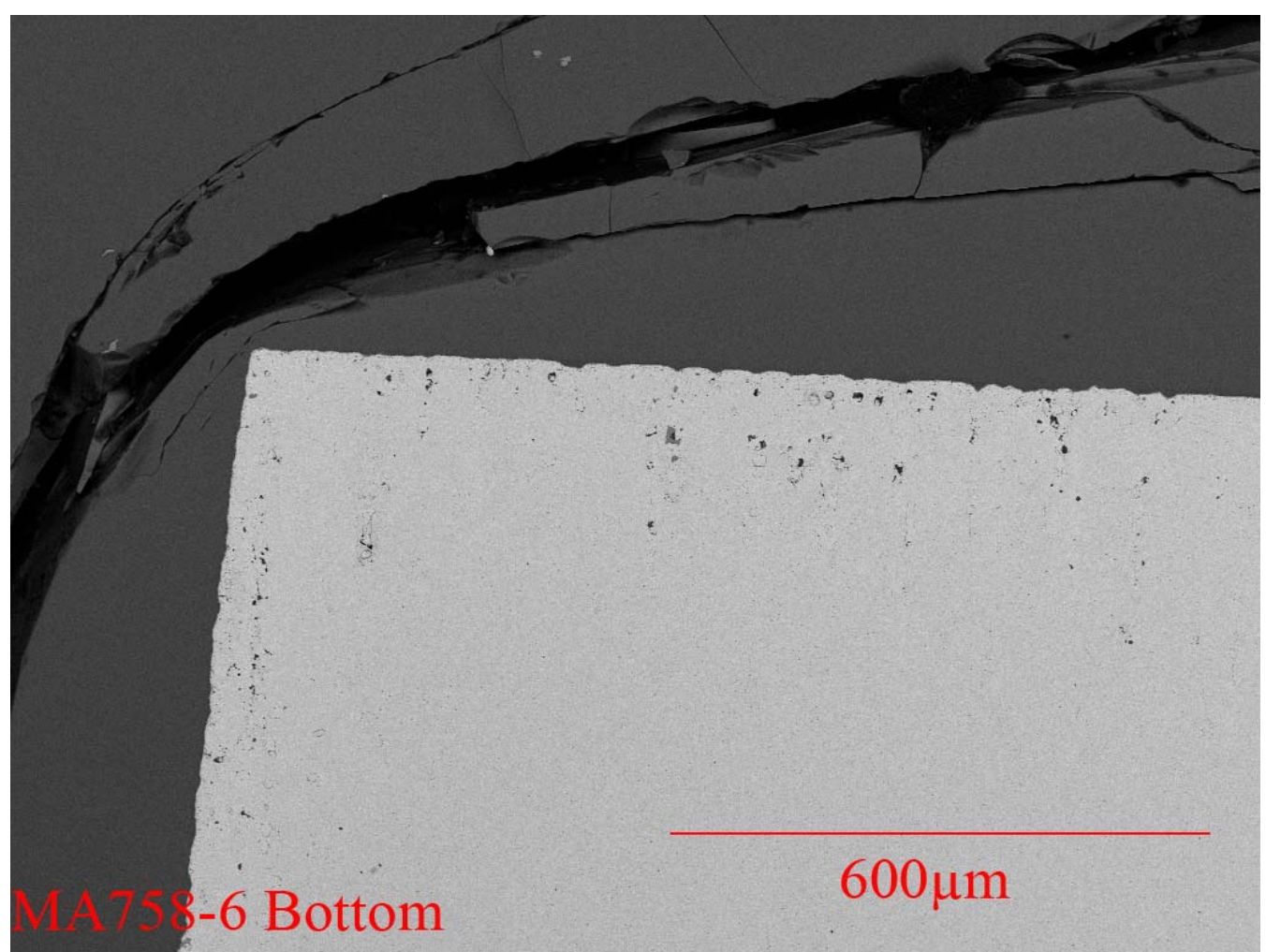

Figure 3.12(e). SEM image of MA758 after 7-day sealed crucible test in HLWS-09 at $1150^{\circ} \mathrm{C}$ showing the tip of the test coupon. 


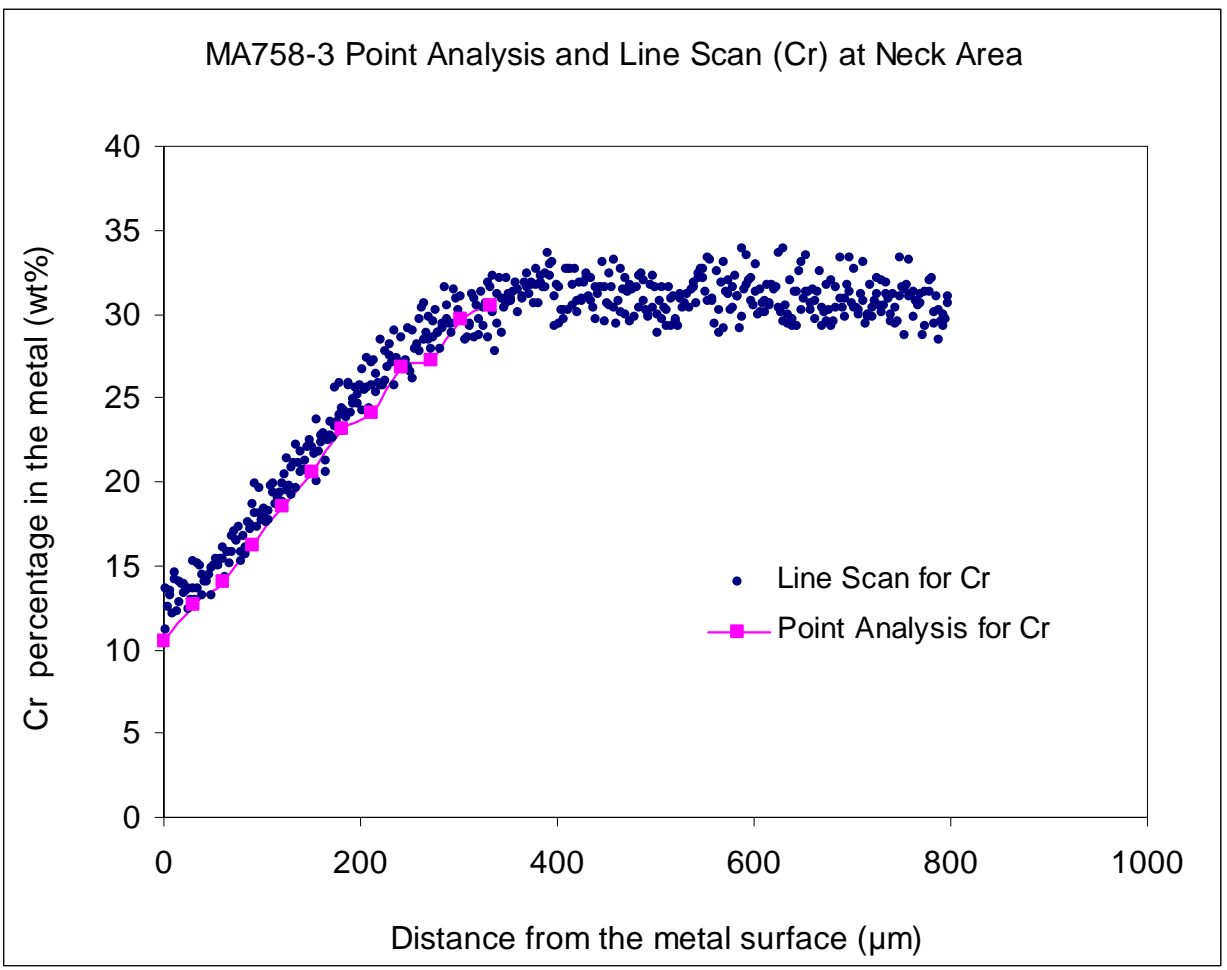

a) MA758 in neck area (standard open crucible)

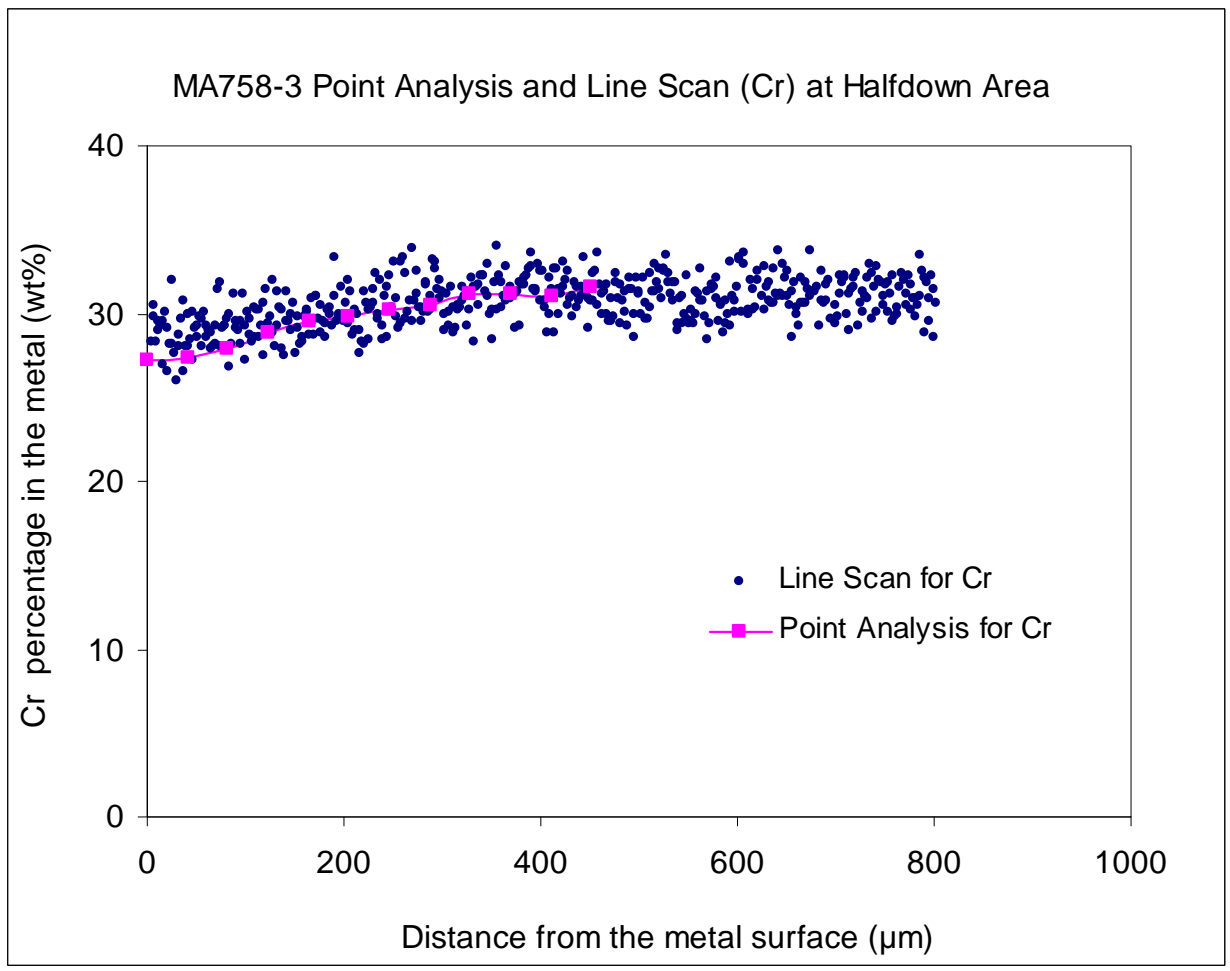

b) MA758 in half-down area (standard open crucible)

Figure 3.13. SEM/EDS analysis of Cr in MA758 after 7-day test in HLWS-09 at $1150^{\circ} \mathrm{C}$. 


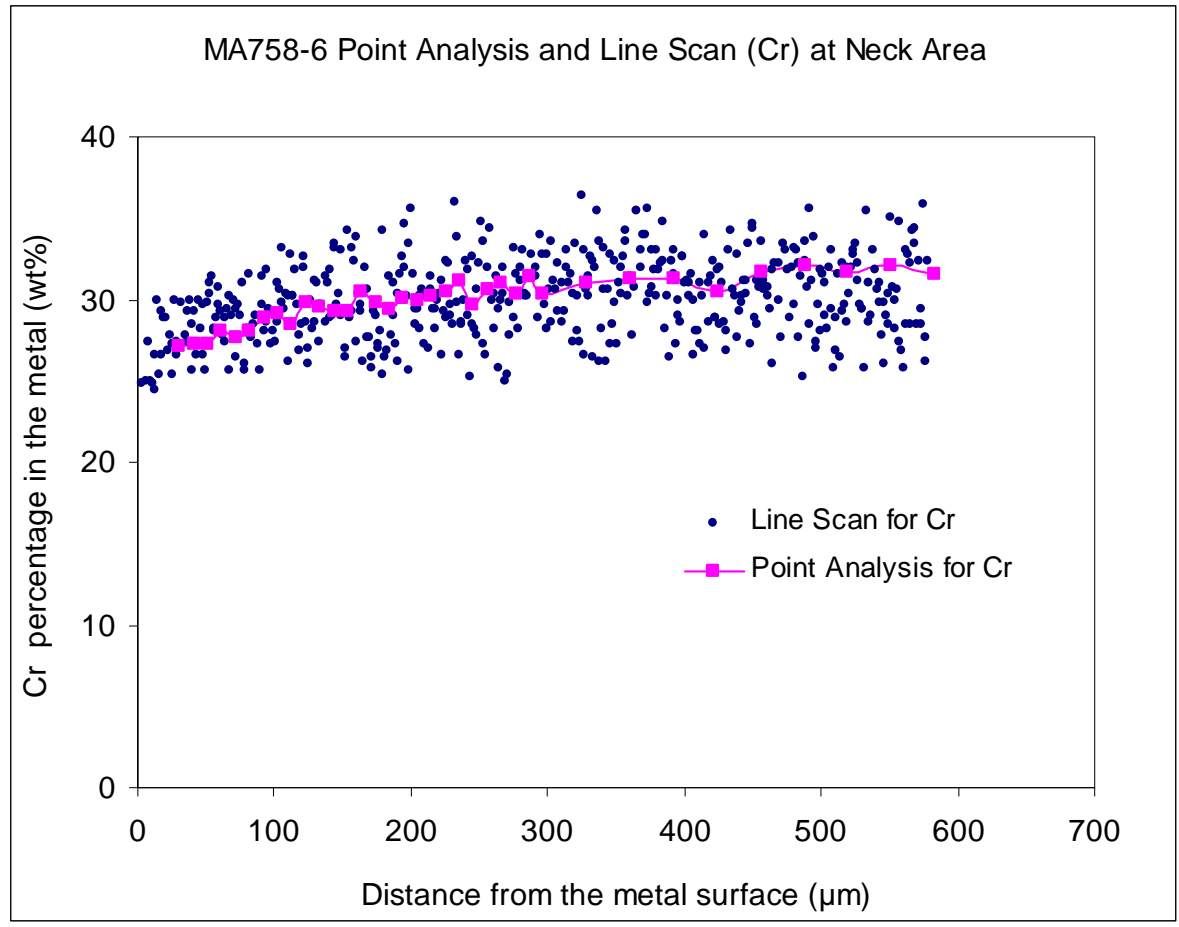

c) MA758 in neck area (sealed crucible)

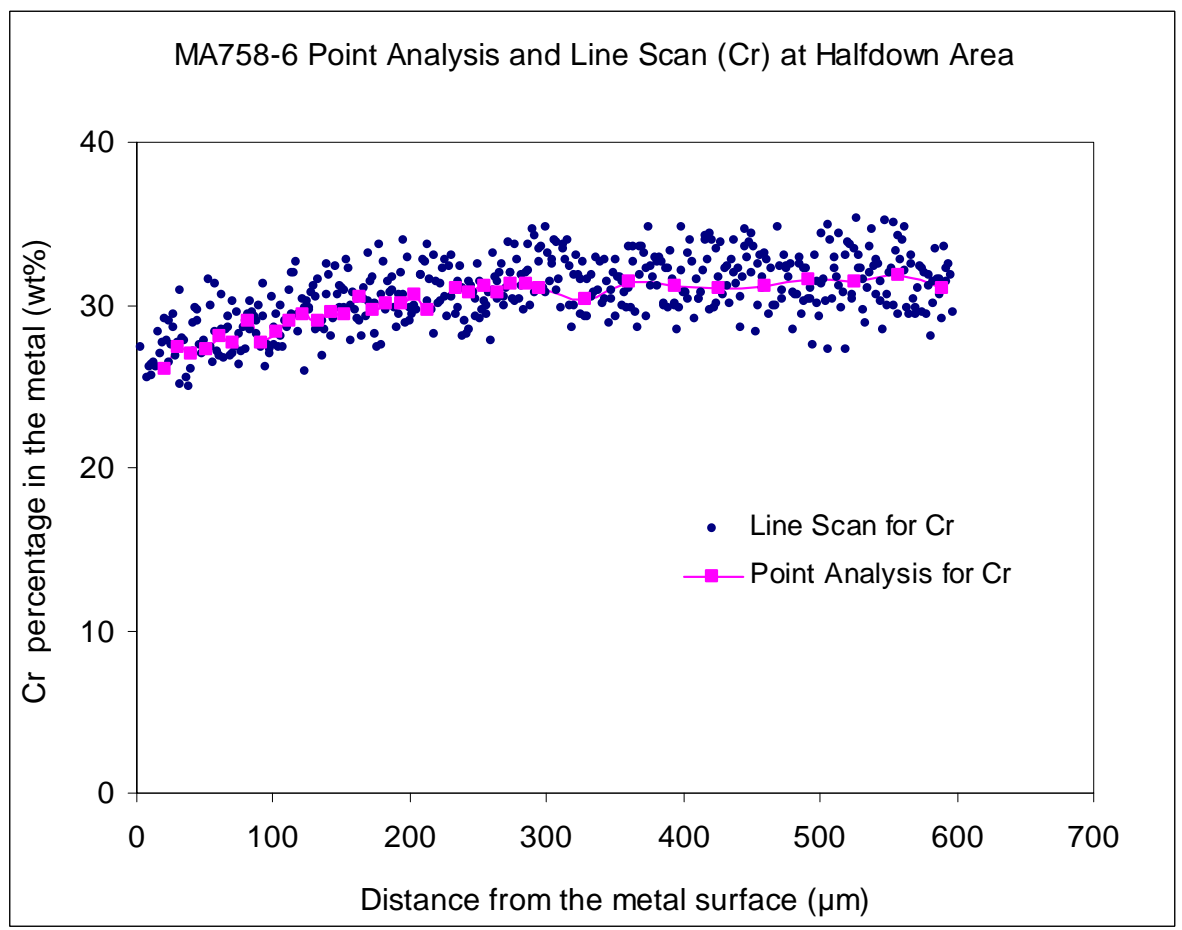

d) MA758 in half down area (sealed crucible)

Figure 3.13. SEM/EDS analysis of $\mathrm{Cr}$ in MA758 after 7-day test in HLWS-09 at $1150^{\circ} \mathrm{C}$ (continued). 


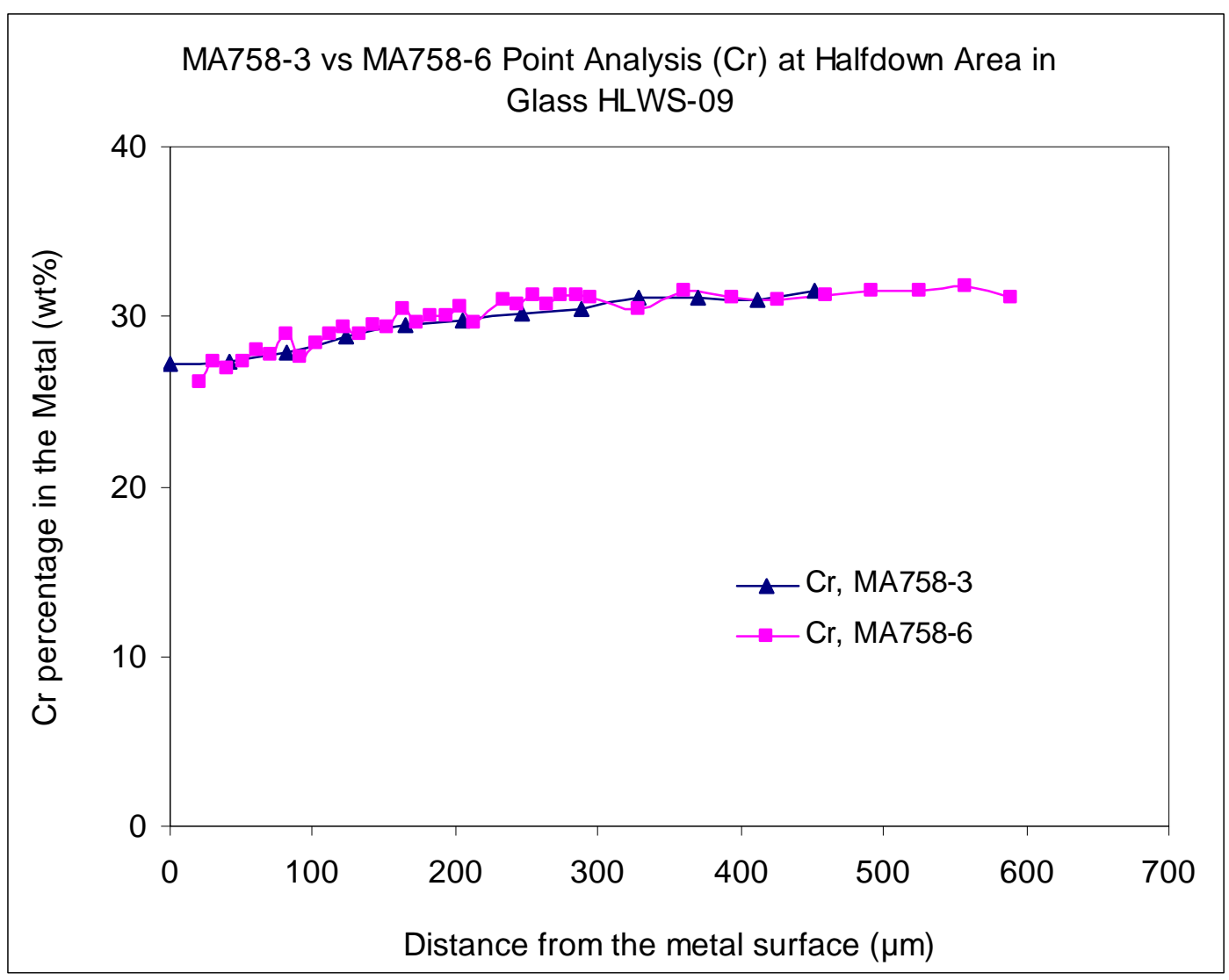

Figure 3.14. Comparison of Cr depletion at half-down areas of MA758 after 7-day corrosion tests in HLWS-09 in the standard open crucible (black triangles) and in the sealed crucible (magenta squares). 


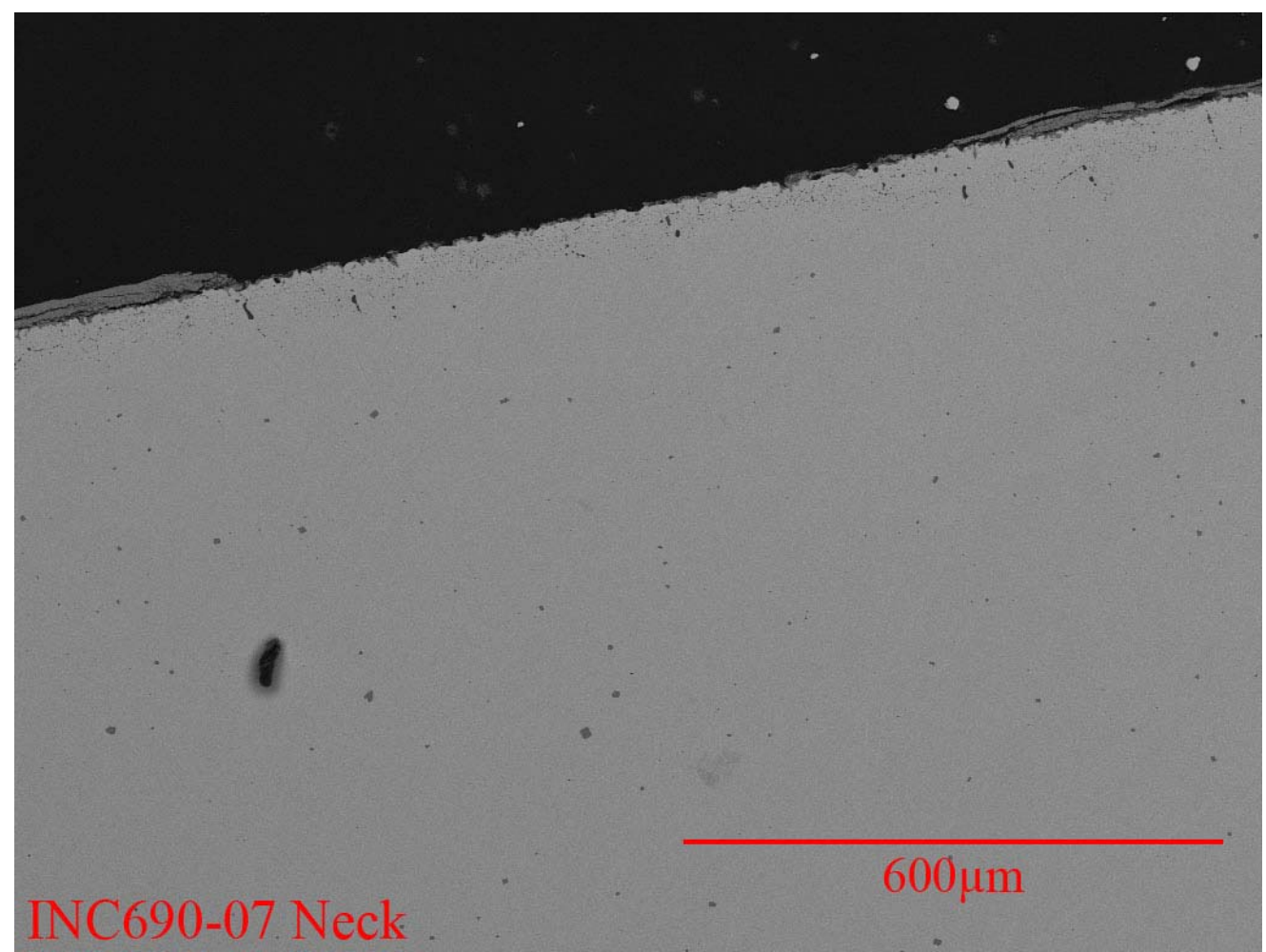

a) Inconel 690 in neck area

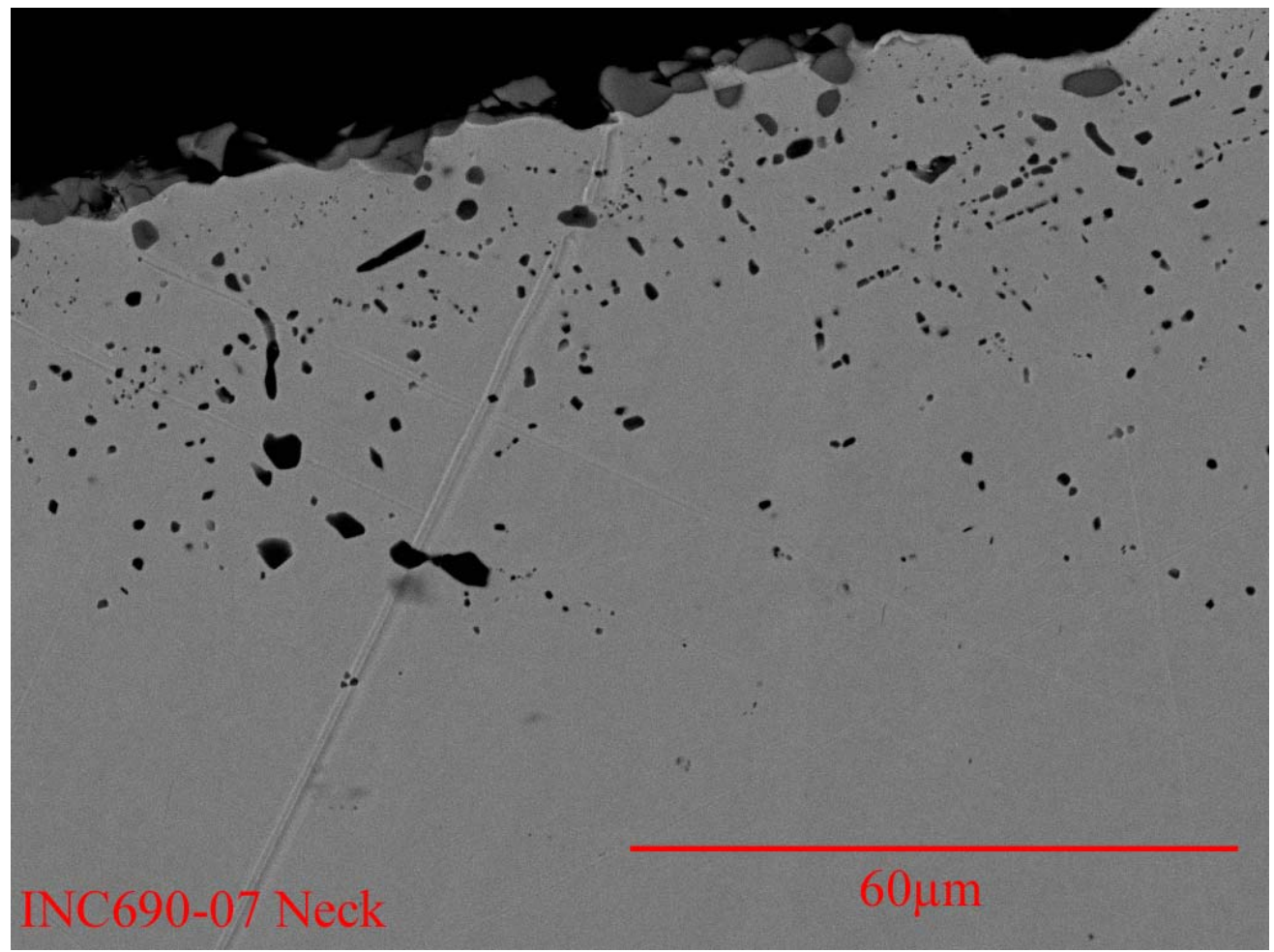

b) Close up view of Inconel 690 in neck area

Figure 3.15. SEM images of Inconel 690 after 7-day sealed crucible test at $1150^{\circ} \mathrm{C}$ in HLWS-27. 


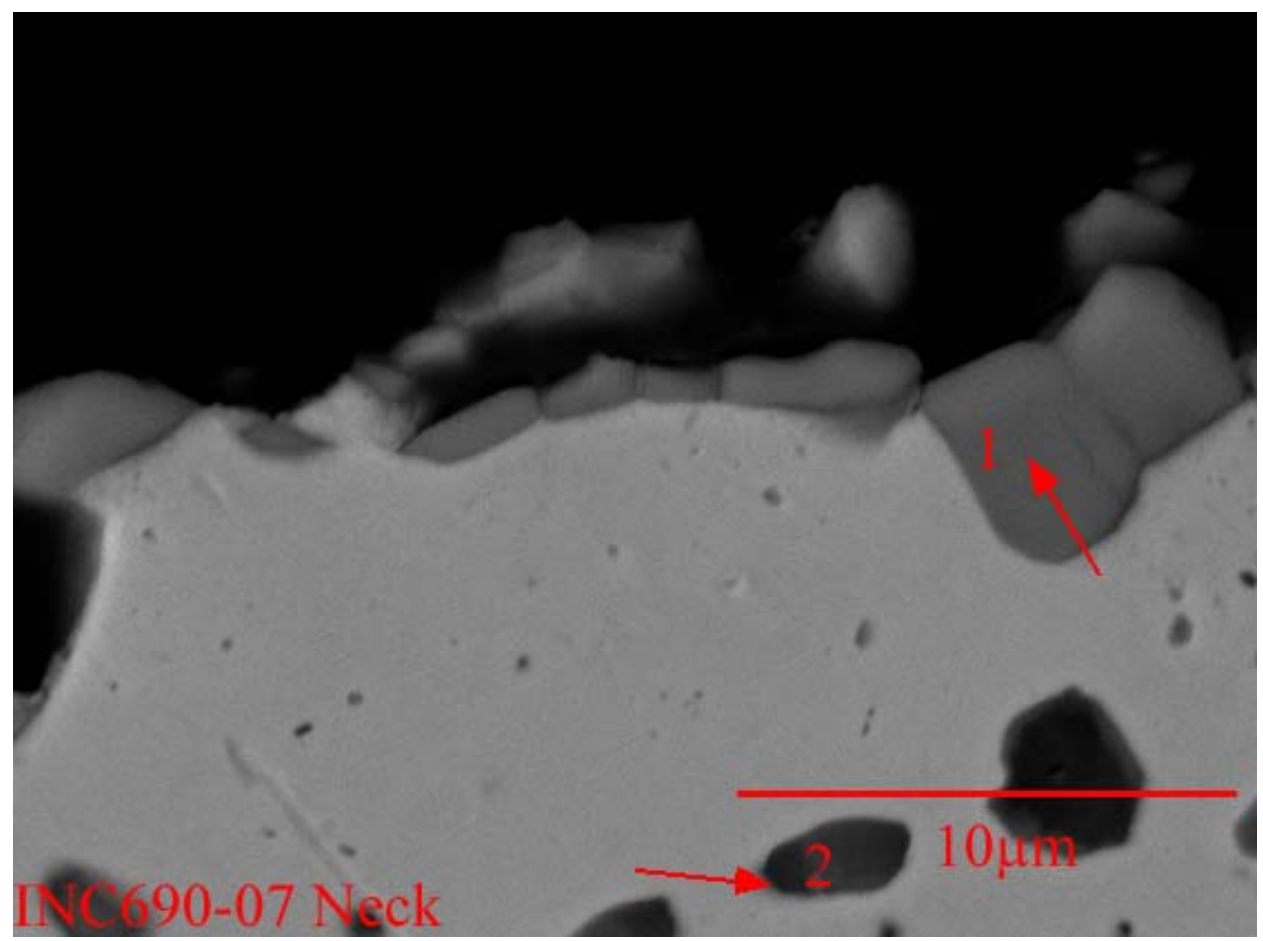

c) Detailed view of Inconel690 in neck area. Arrows point to chromium oxide (1) and chromium and aluminum oxide (2).

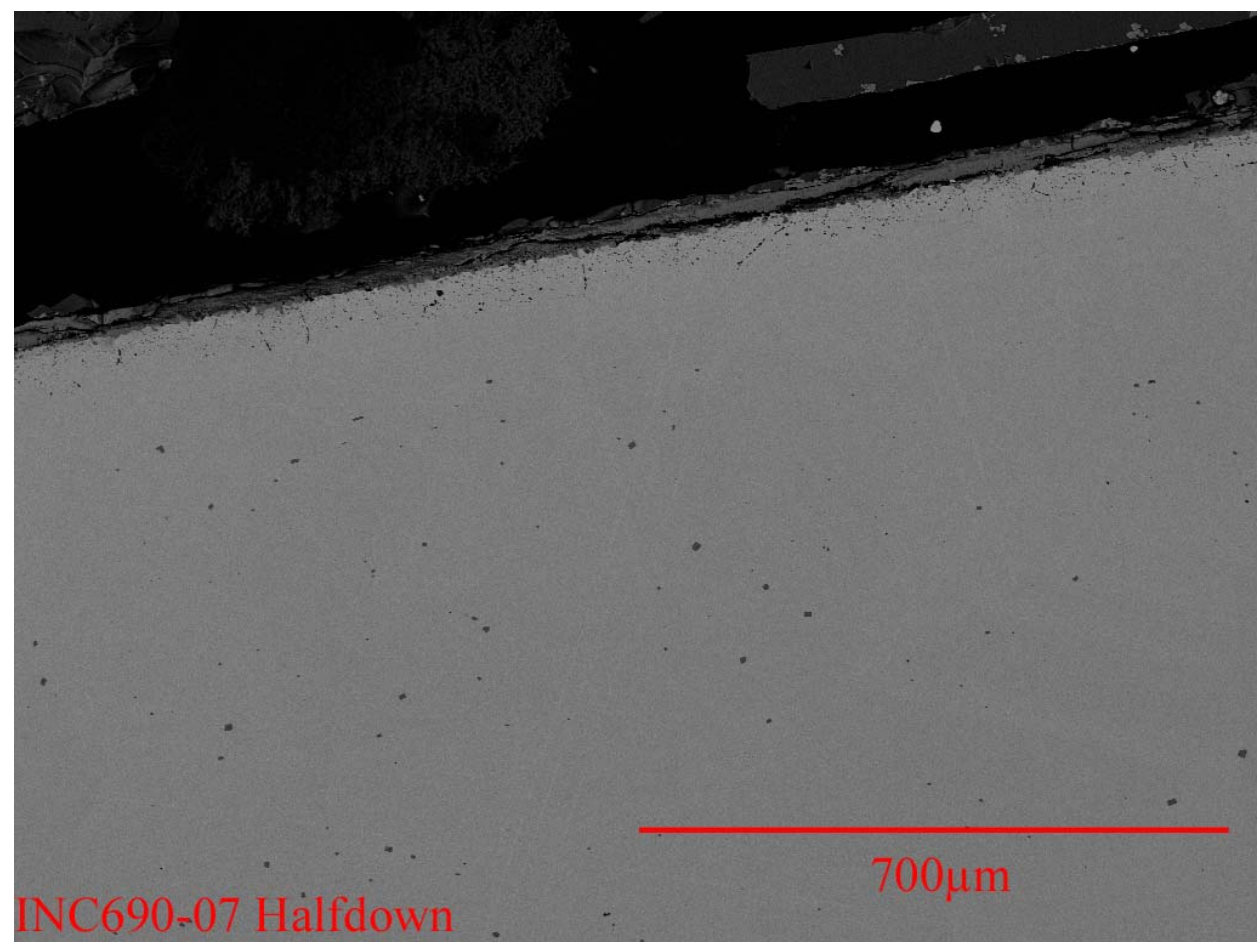

d) Inconel690 in half down area

Figure 3.15. SEM images of Inconel 690 after 7-day sealed crucible test at $1150^{\circ} \mathrm{C}$ in HLWS-27 (continued). 


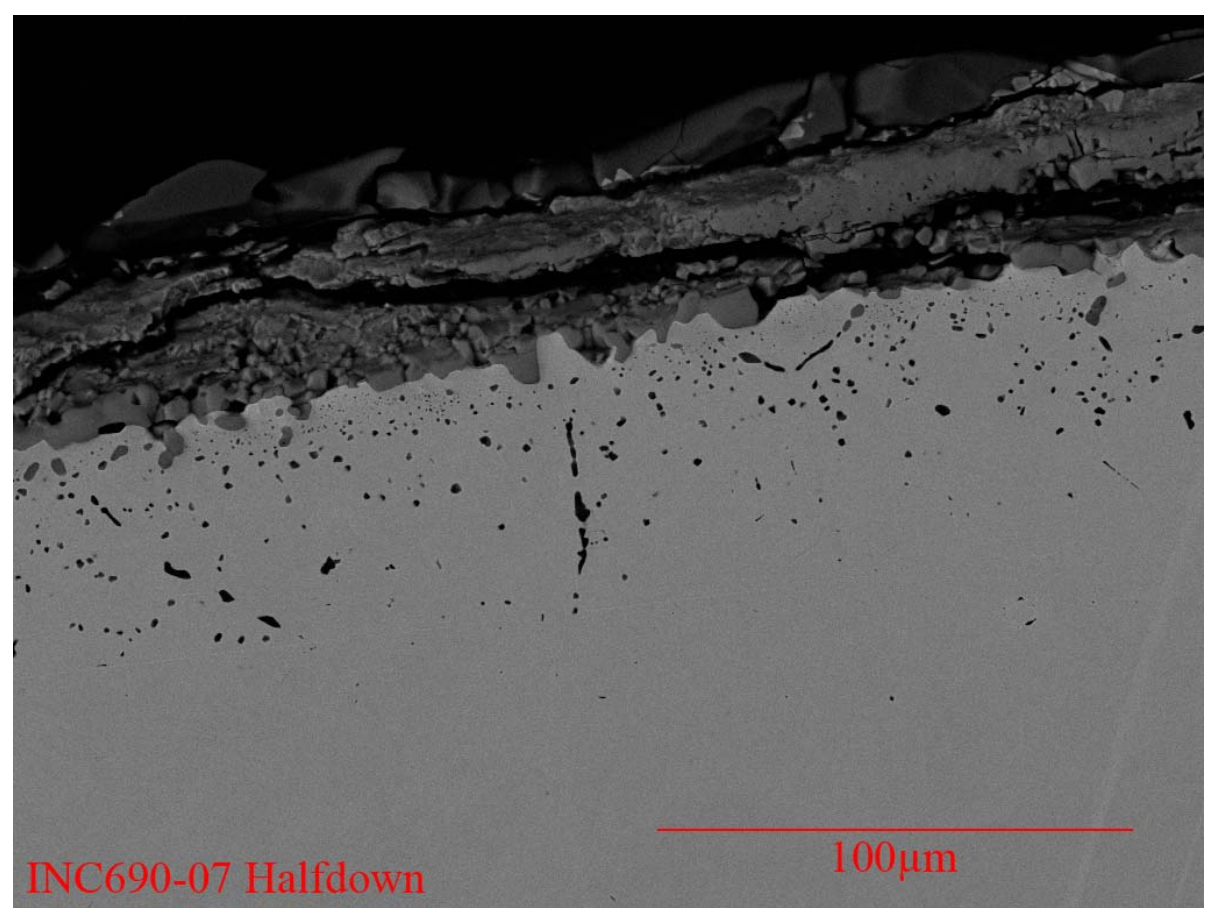

e) Close up view of Inconel 690 in half-down area

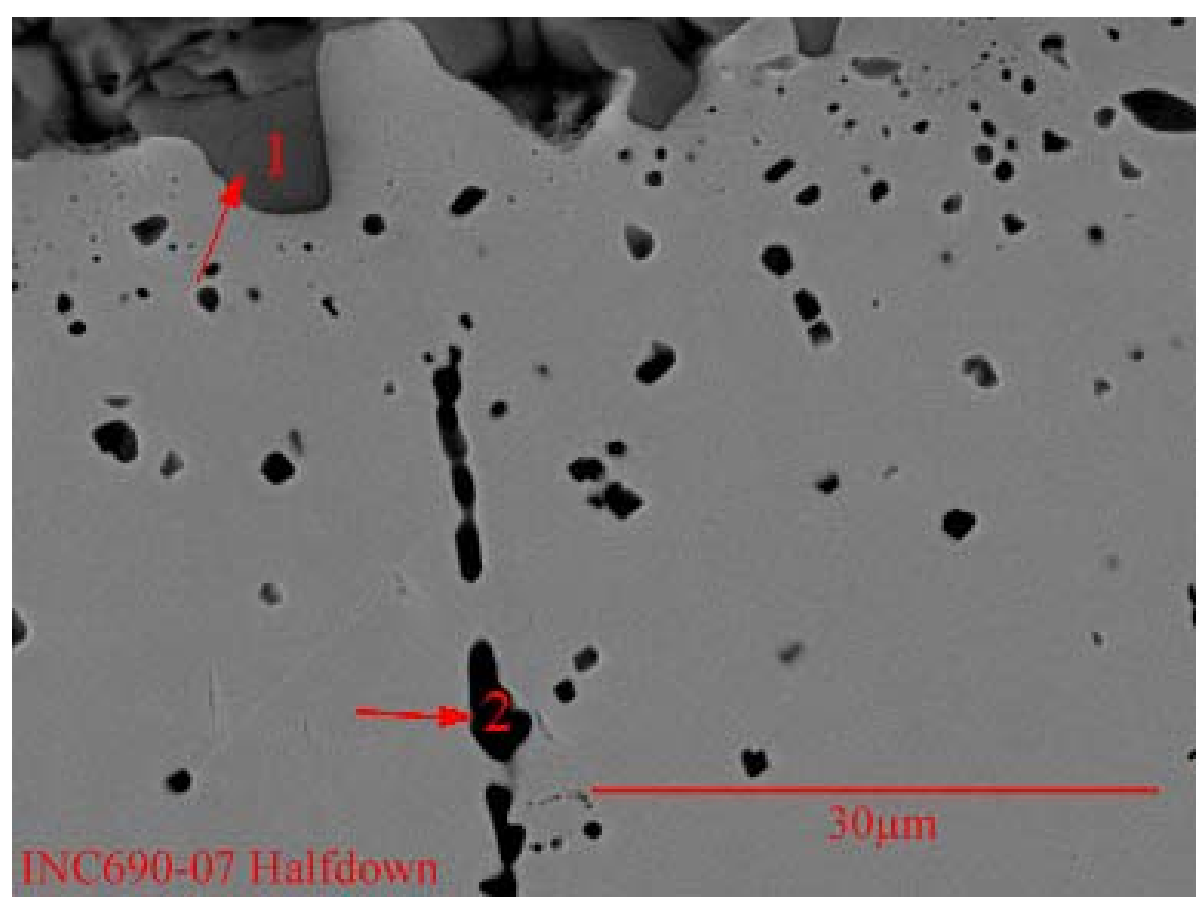

f) Detailed view of Inconel 690 in half-down area. Arrows point to chromium oxide (1) and aluminum and chromium oxide (2)

Figure 3.15. SEM images of Inconel 690 after 7-day sealed crucible test at $1150^{\circ} \mathrm{C}$ in HLWS-27 (continued). 


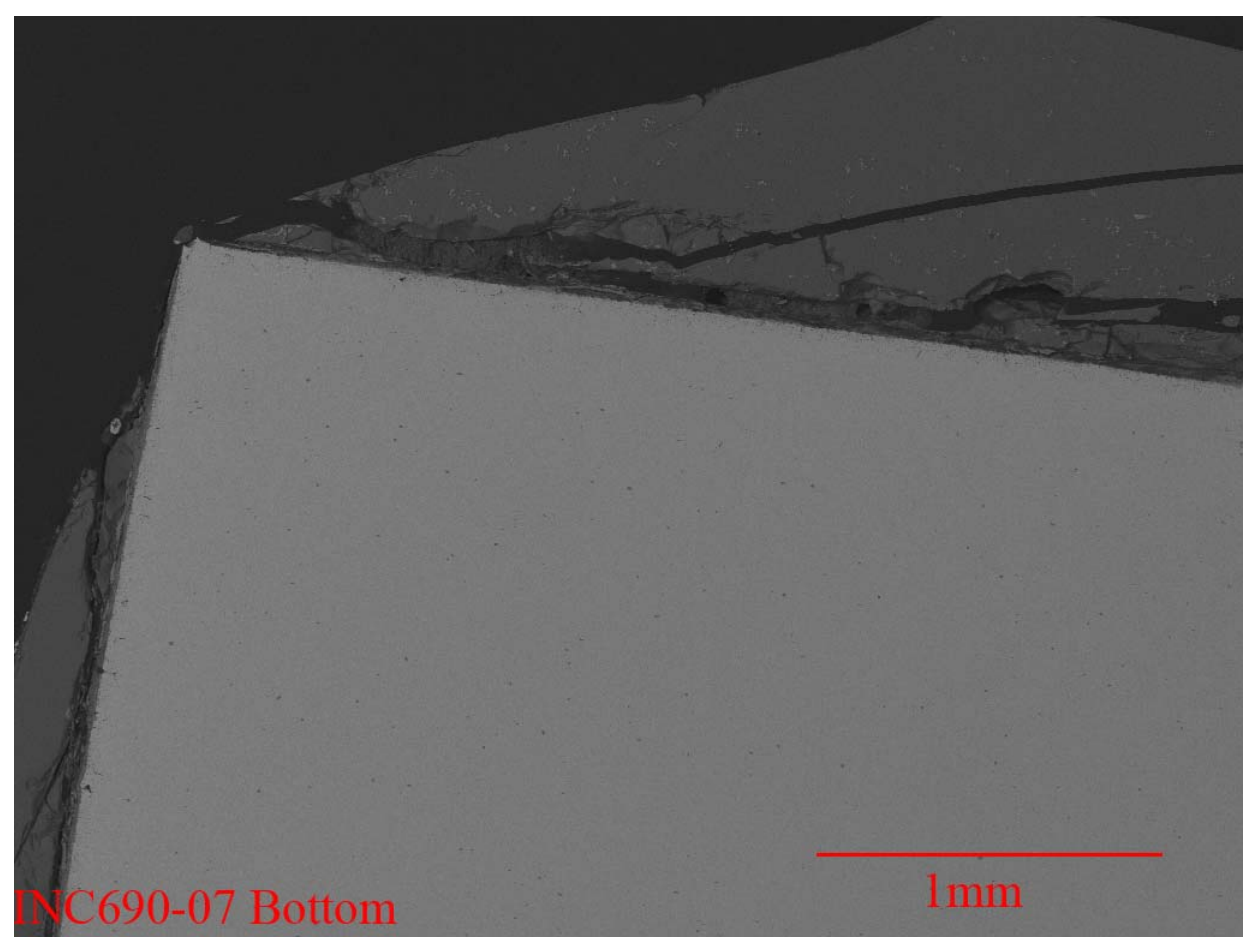

g) Inconel 690 near tip of test coupon

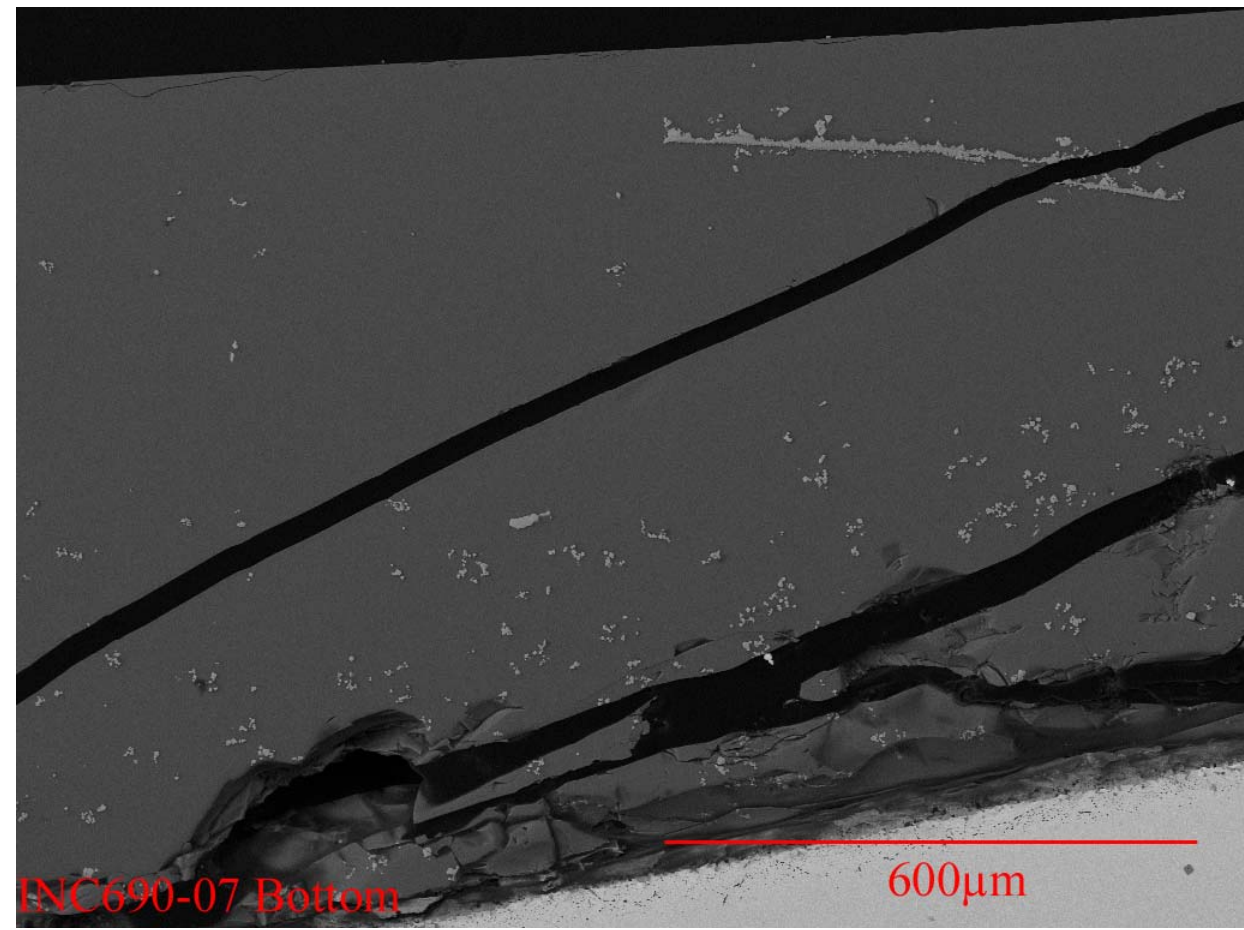

h) Inconel 690 near tip of test coupon. Light grey aggregates of crystals are spinel dispersed with glass adjacent to Inconel 690.

Figure 3.15. SEM images of Inconel 690 after 7-day sealed crucible test at $1150^{\circ} \mathrm{C}$ in HLWS-27 (continued). 


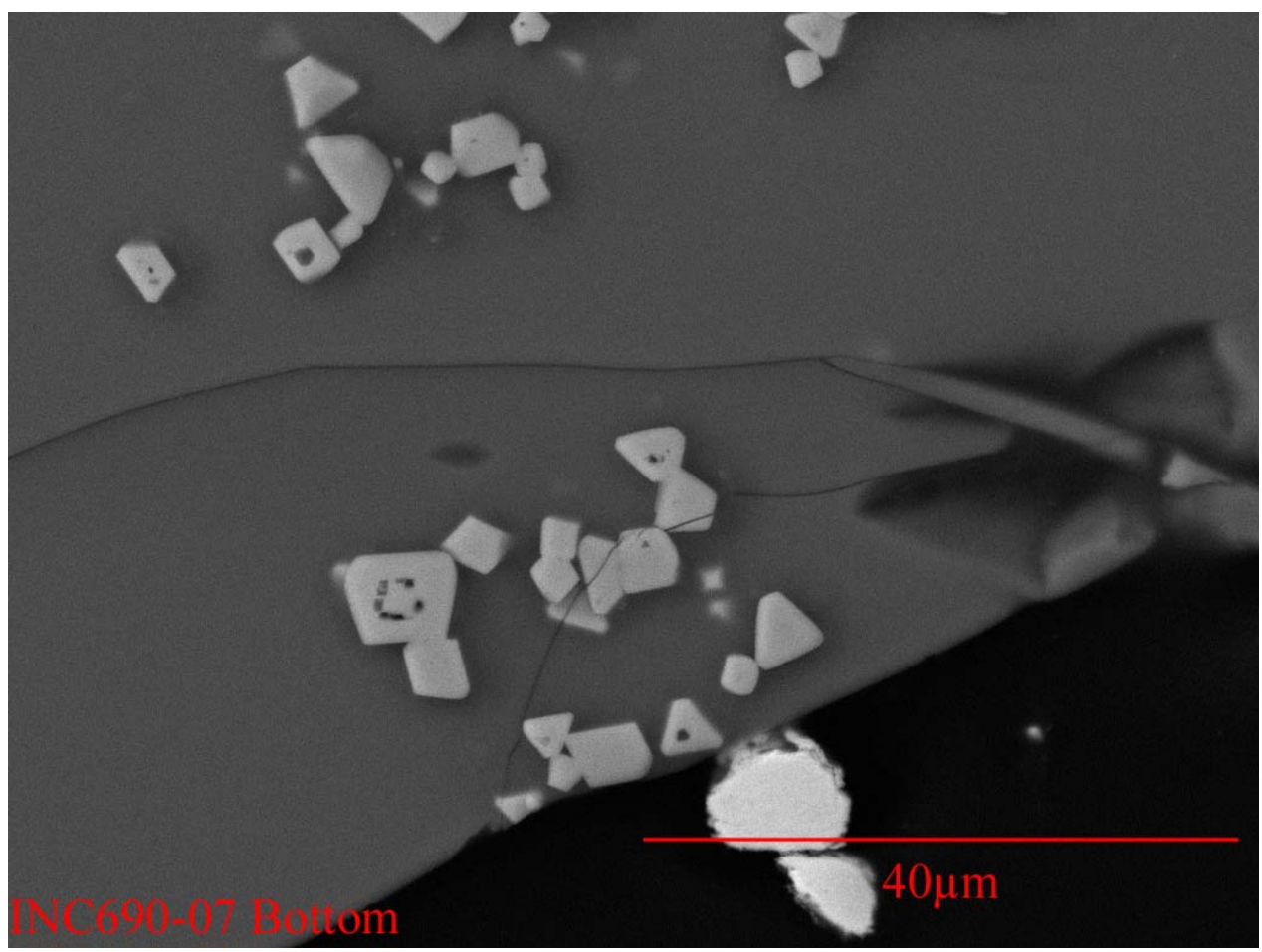

i) Spinel crystals (Cr, Mn, Fe and Ni) near the tip of the metal coupon

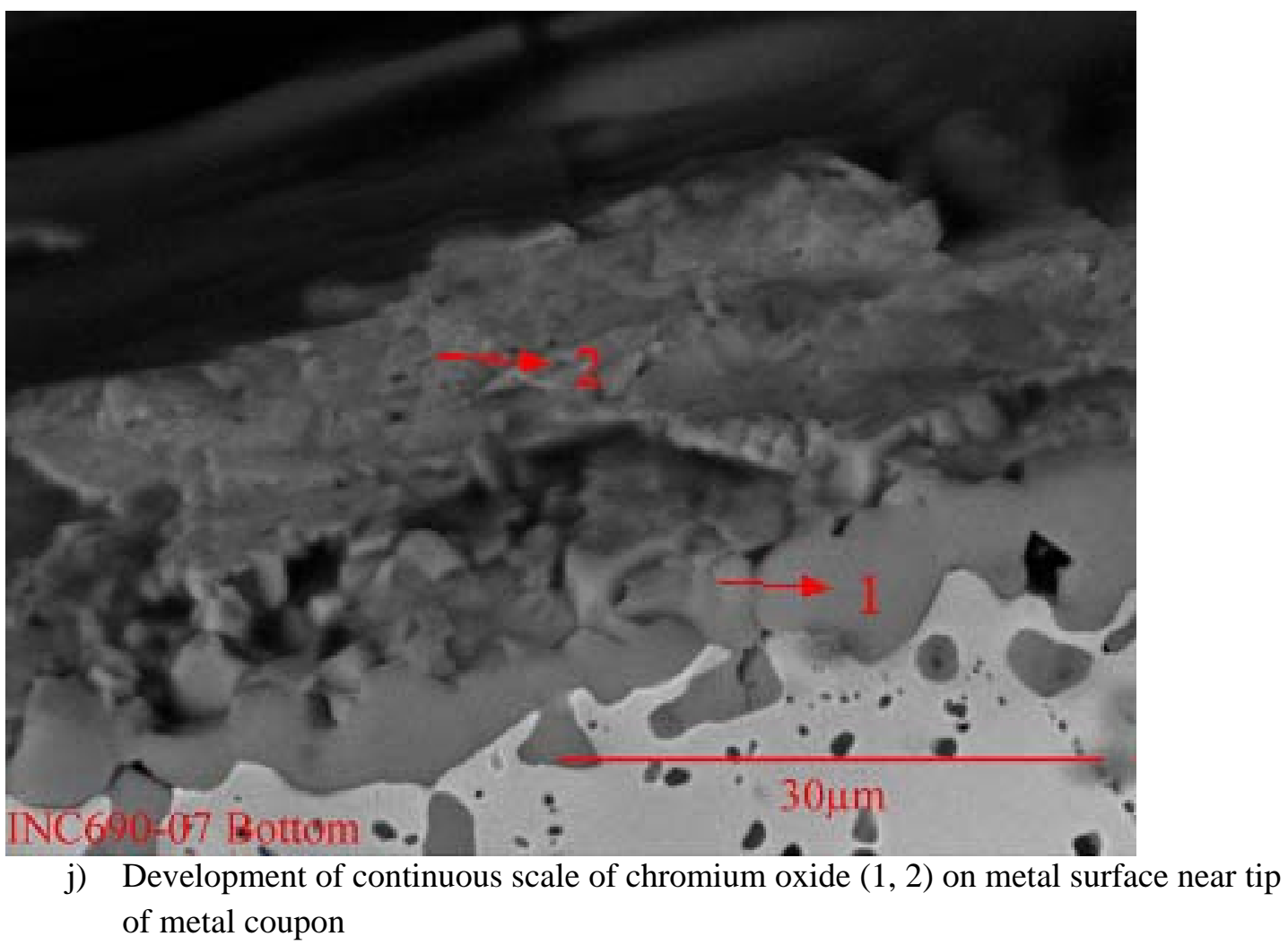

Figure 3.15. SEM images of Inconel 690 after 7-day sealed crucible test at $1150^{\circ} \mathrm{C}$ in HLWS-27 (continued). 


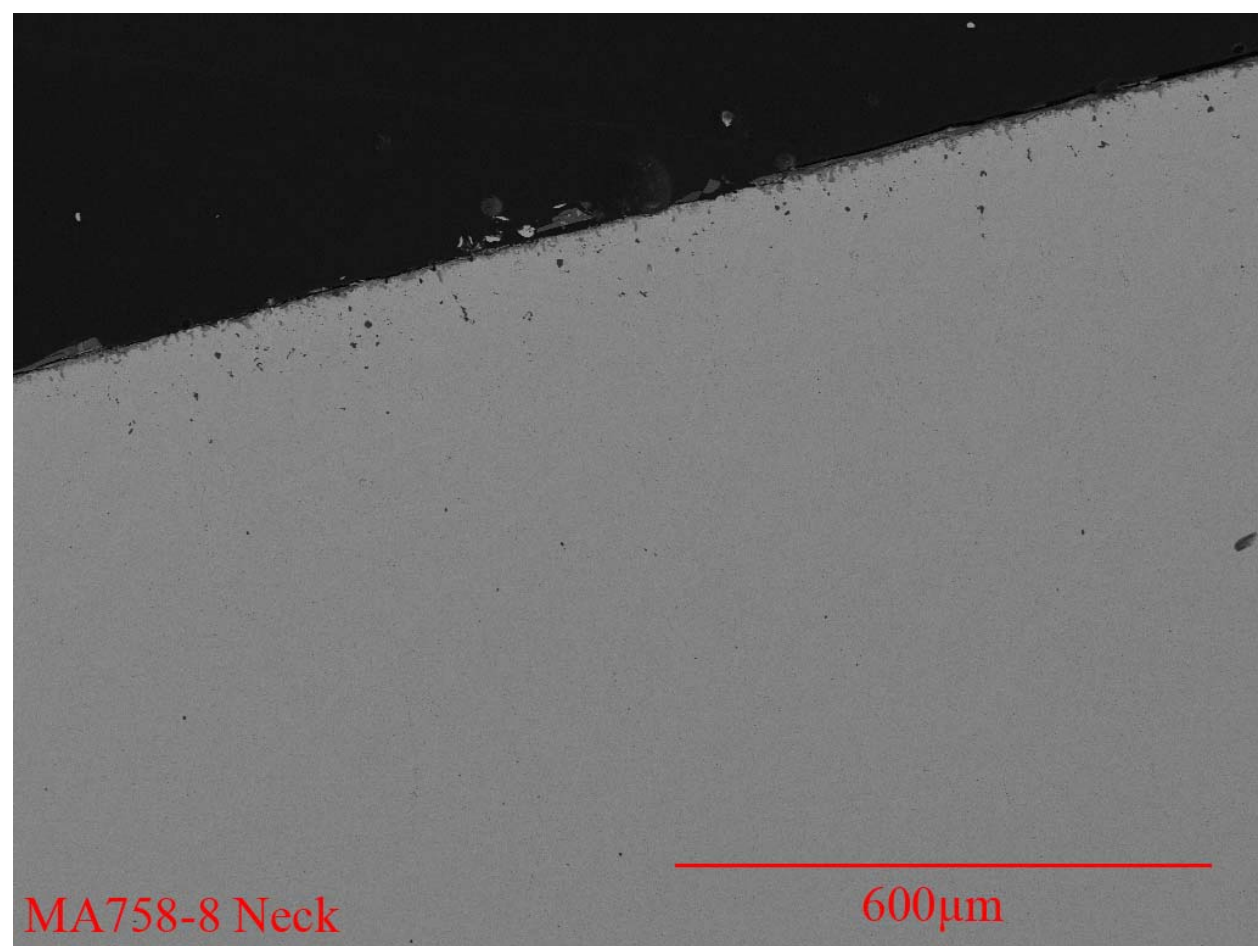

a) MA758 in neck area

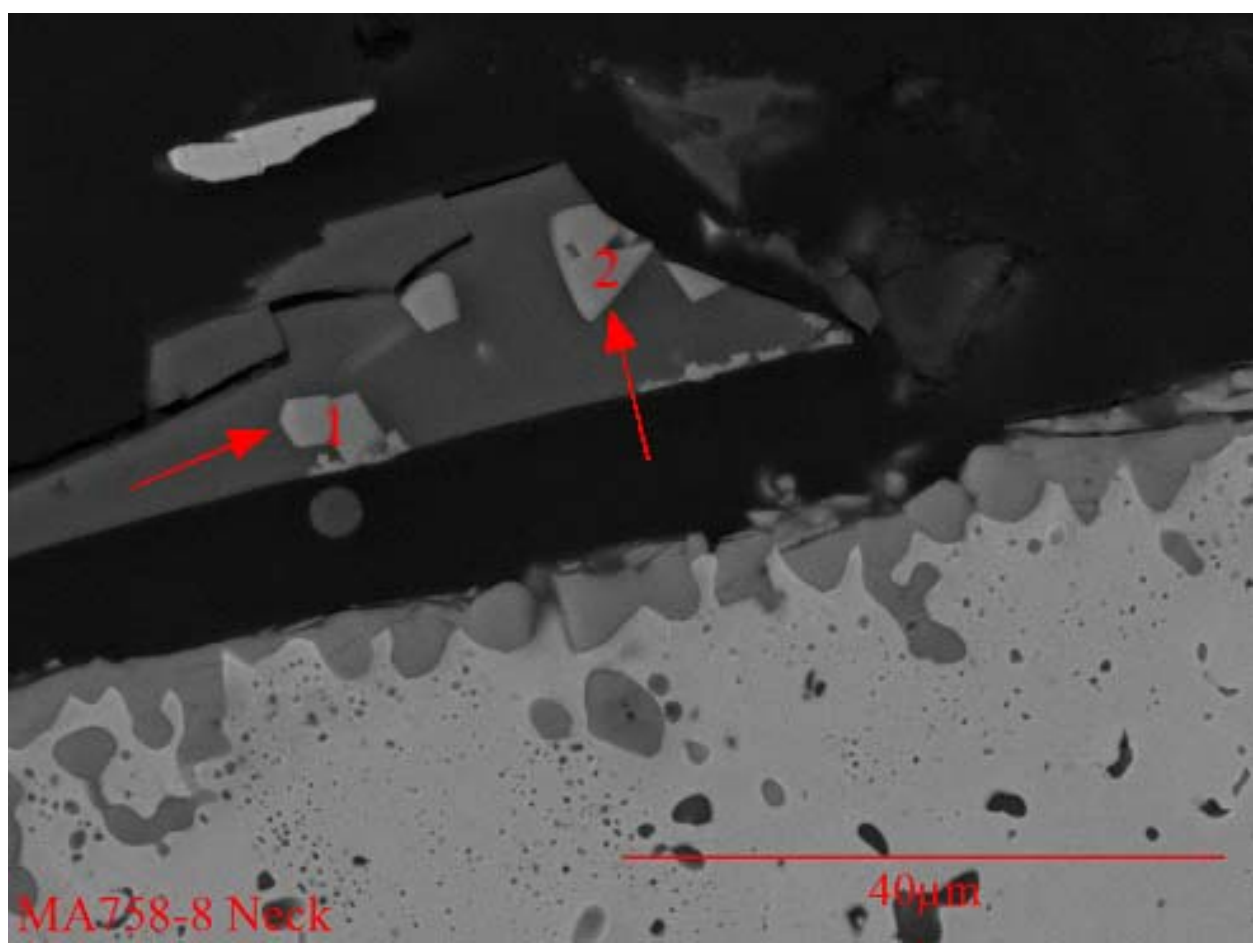

b) Close up view of MA758 in neck area. Arrows point to spinel (1 and 2) composed mainly of $\mathrm{Cr}, \mathrm{Fe}, \mathrm{Mn}$, Ni. Light grey pockets in direct contact with bright metal are continuous scale of chromium oxide.

Figure 3.16. SEM images of MA758 after 7-day sealed crucible corrosion test in HLWS-27 at $1150^{\circ} \mathrm{C}$. 


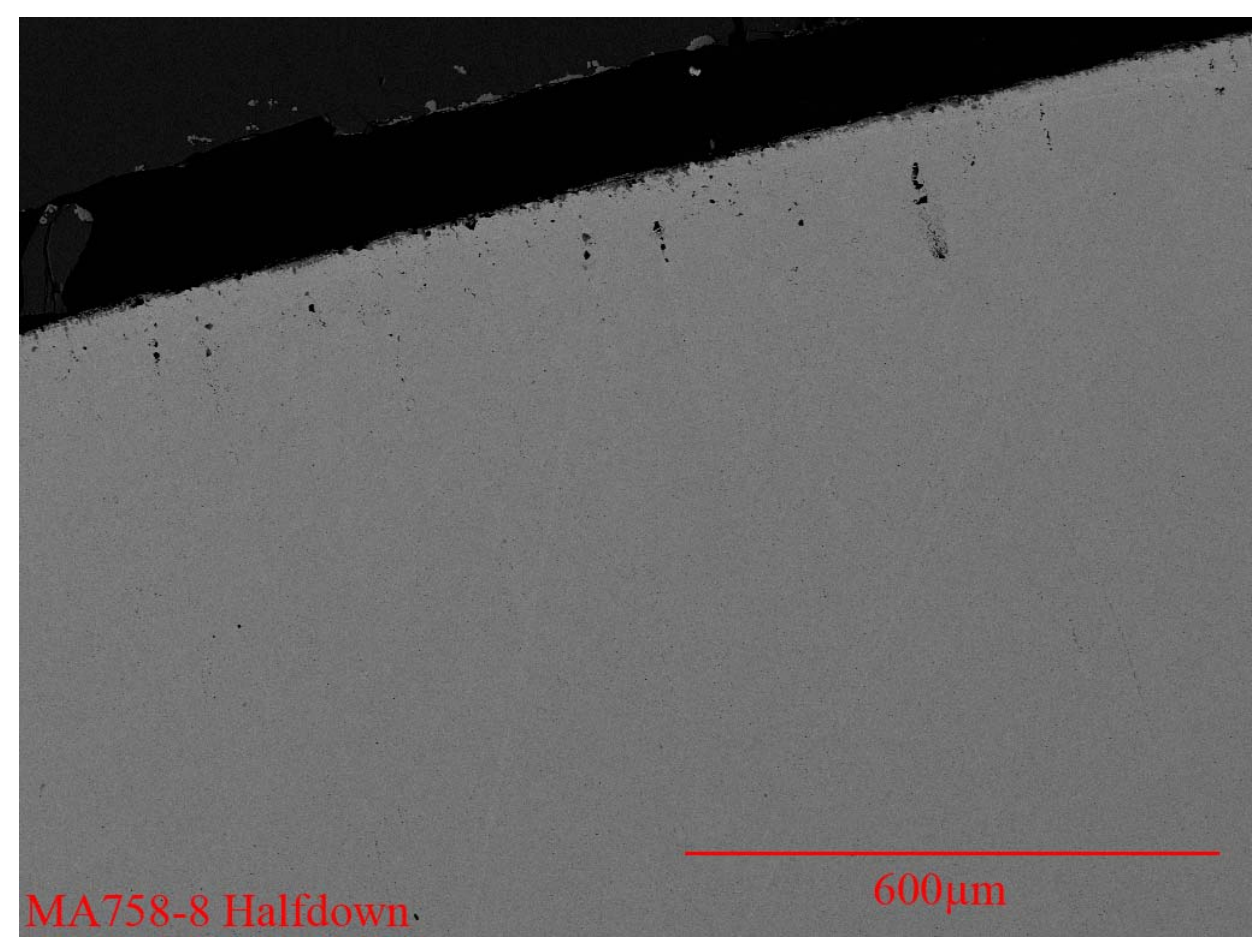

c) MA758 in half-down area

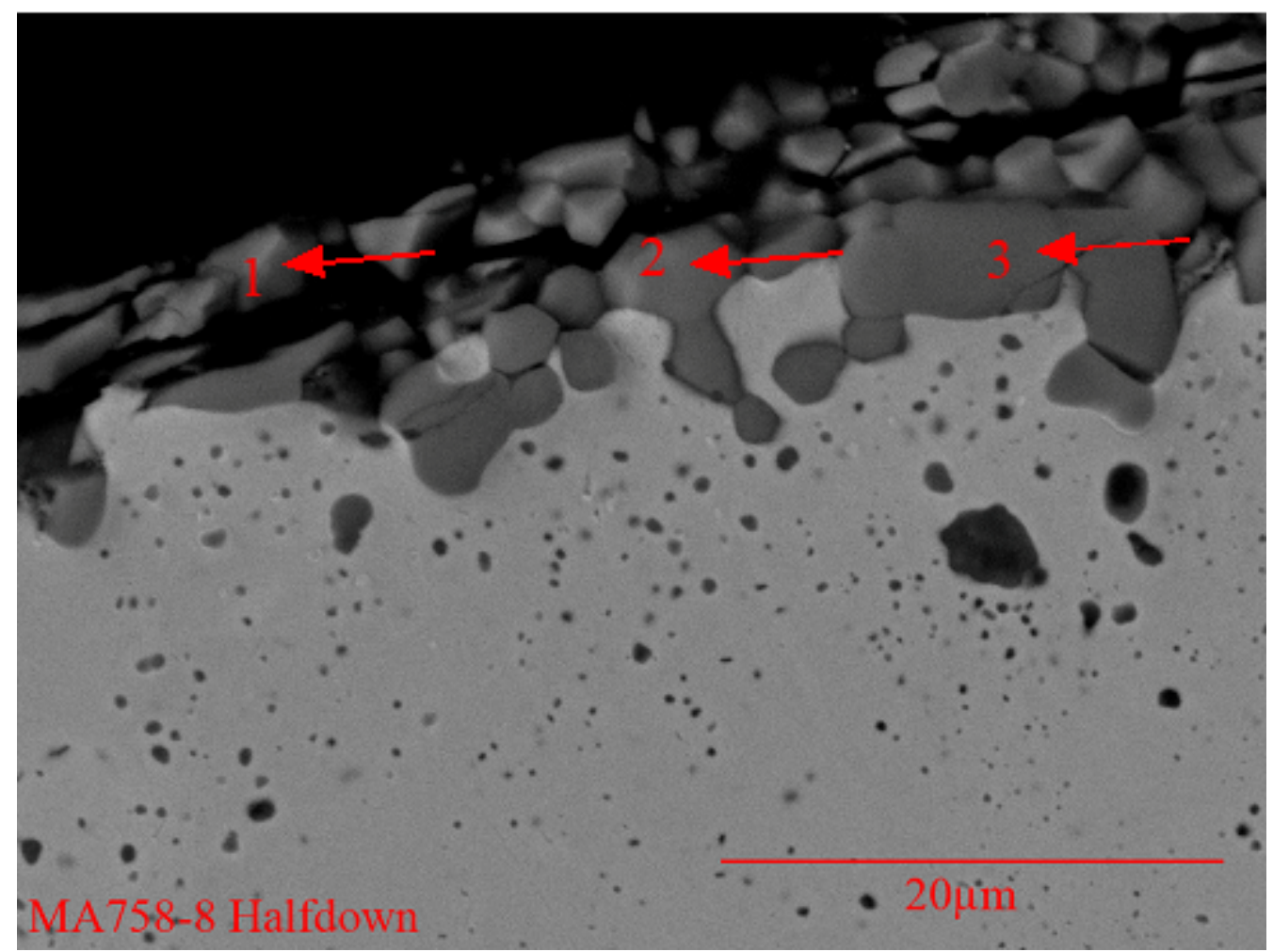

d) Close up view of MA758 in half-down area. Light grey nodules intergrowing at the metal surface are chromium oxide $(1,2,3)$.

Figure 3.16. SEM images of MA758 after 7-day sealed crucible corrosion test in HLWS-27 at $1150^{\circ} \mathrm{C}$ (continued). 


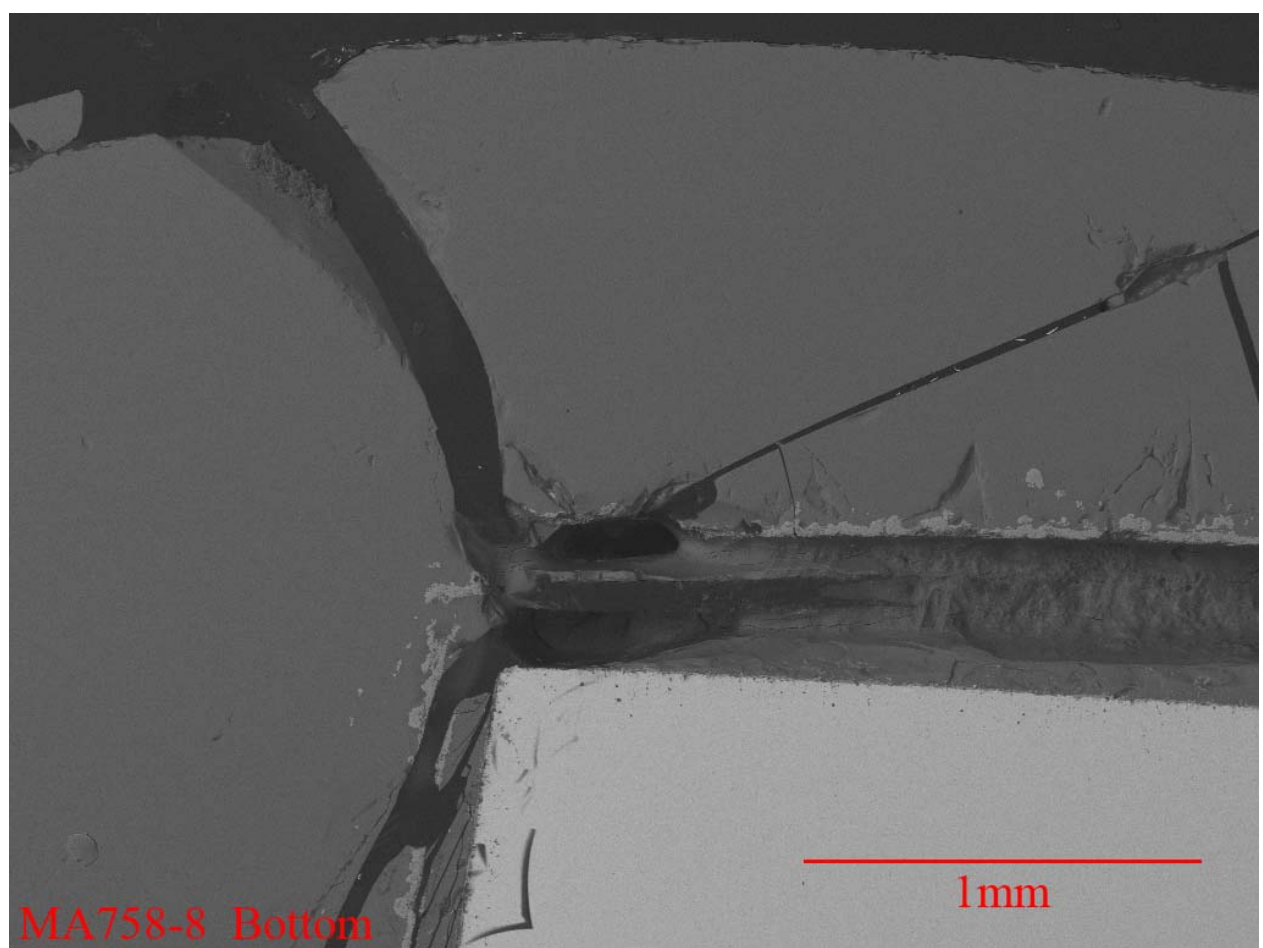

e) MA758 near tip of test coupon. Light grey scale was detached from metal surface.

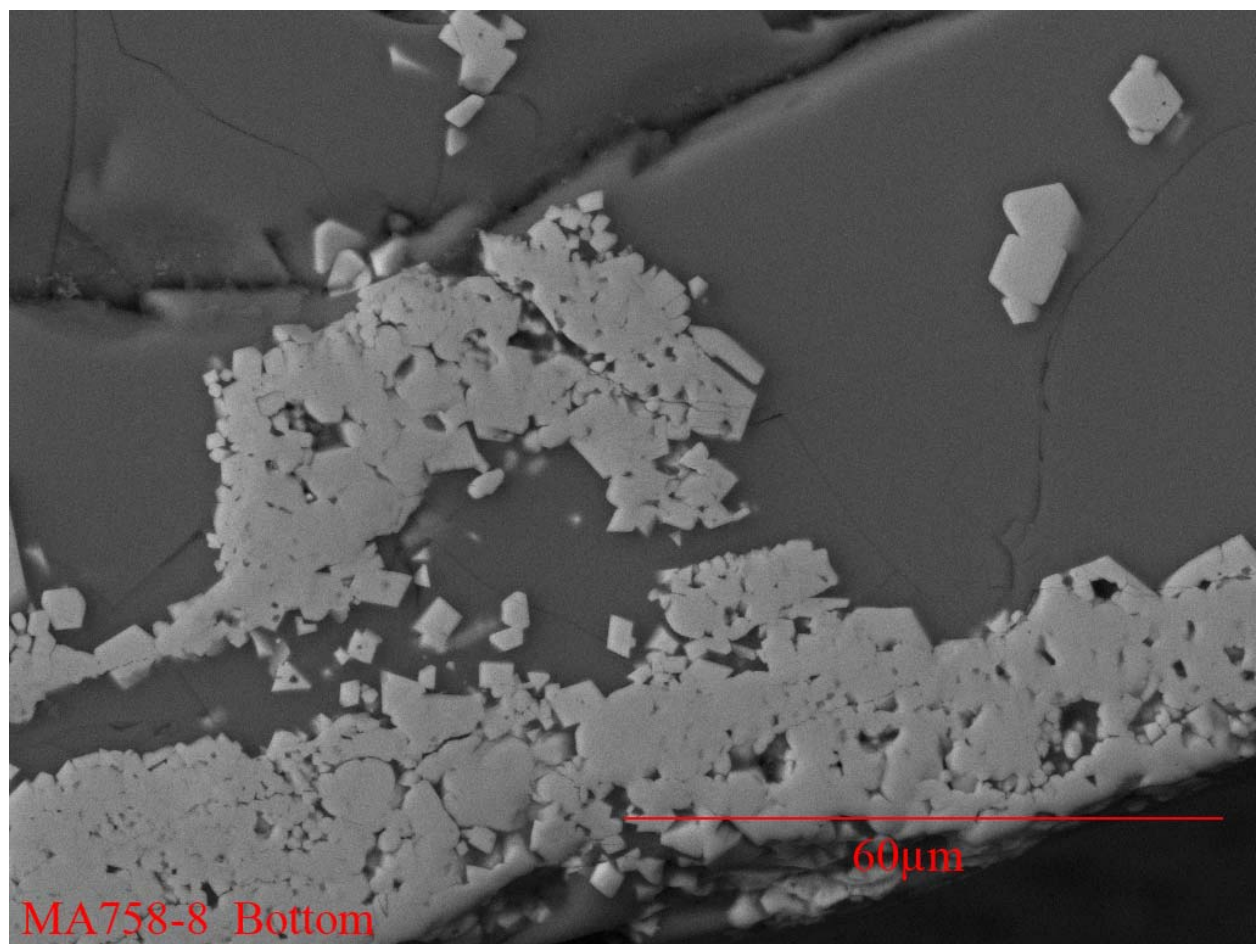

f) Detailed view of spinel (Cr, Mn, Fe, Ni) adjacent to metal surface near tip of test coupon

Figure 3.16. SEM images of MA758 after 7-day sealed crucible corrosion test in HLWS-27 at $1150^{\circ} \mathrm{C}$ (continued). 


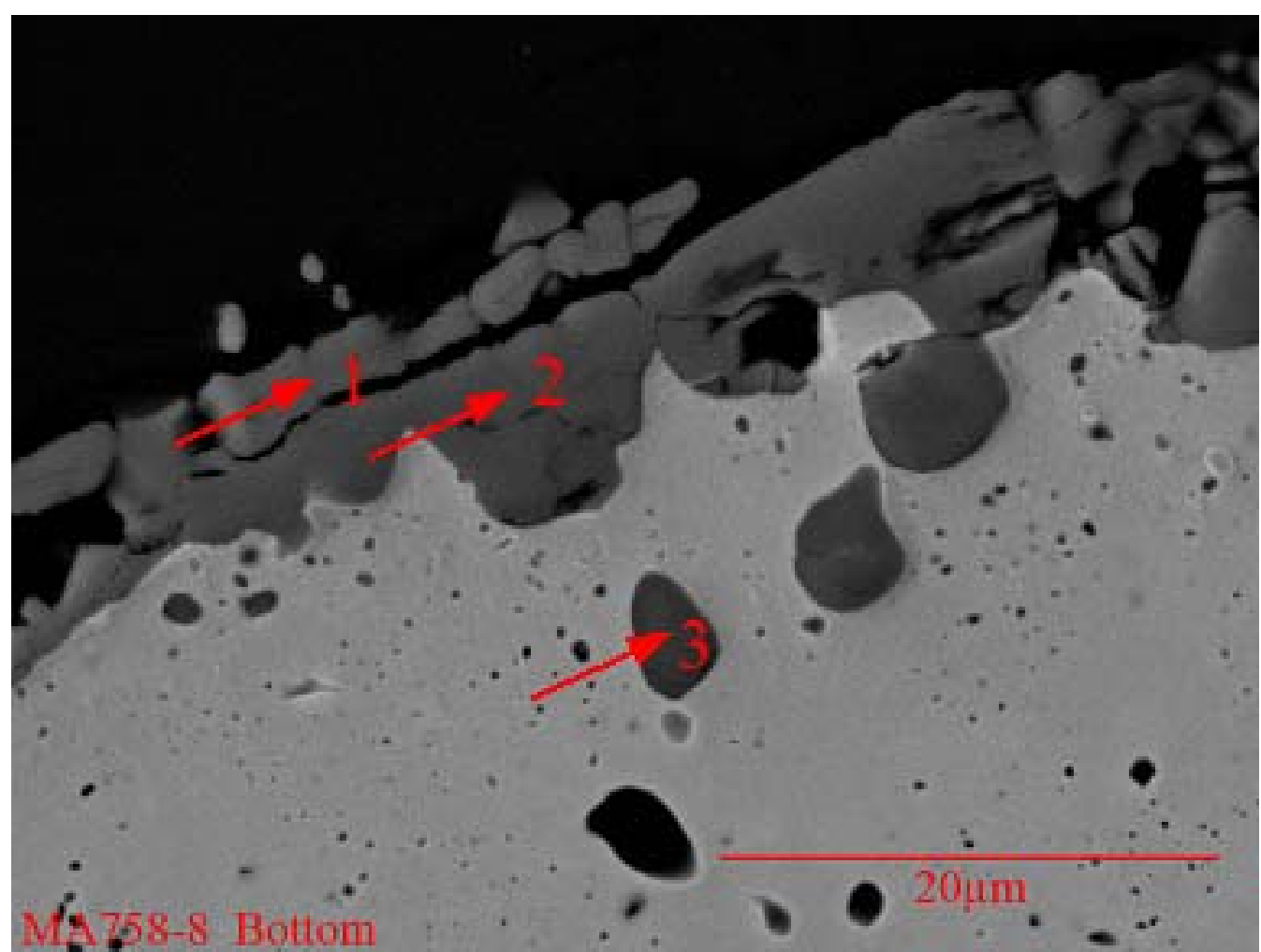

g) MA758 near tip of test coupon. Arrows point to continuous scale of chromium oxide $(1,2,3)$.

Figure 3.16. SEM images of MA758 after 7-day sealed crucible corrosion test in HLWS-27 at $1150^{\circ} \mathrm{C}$ (continued). 


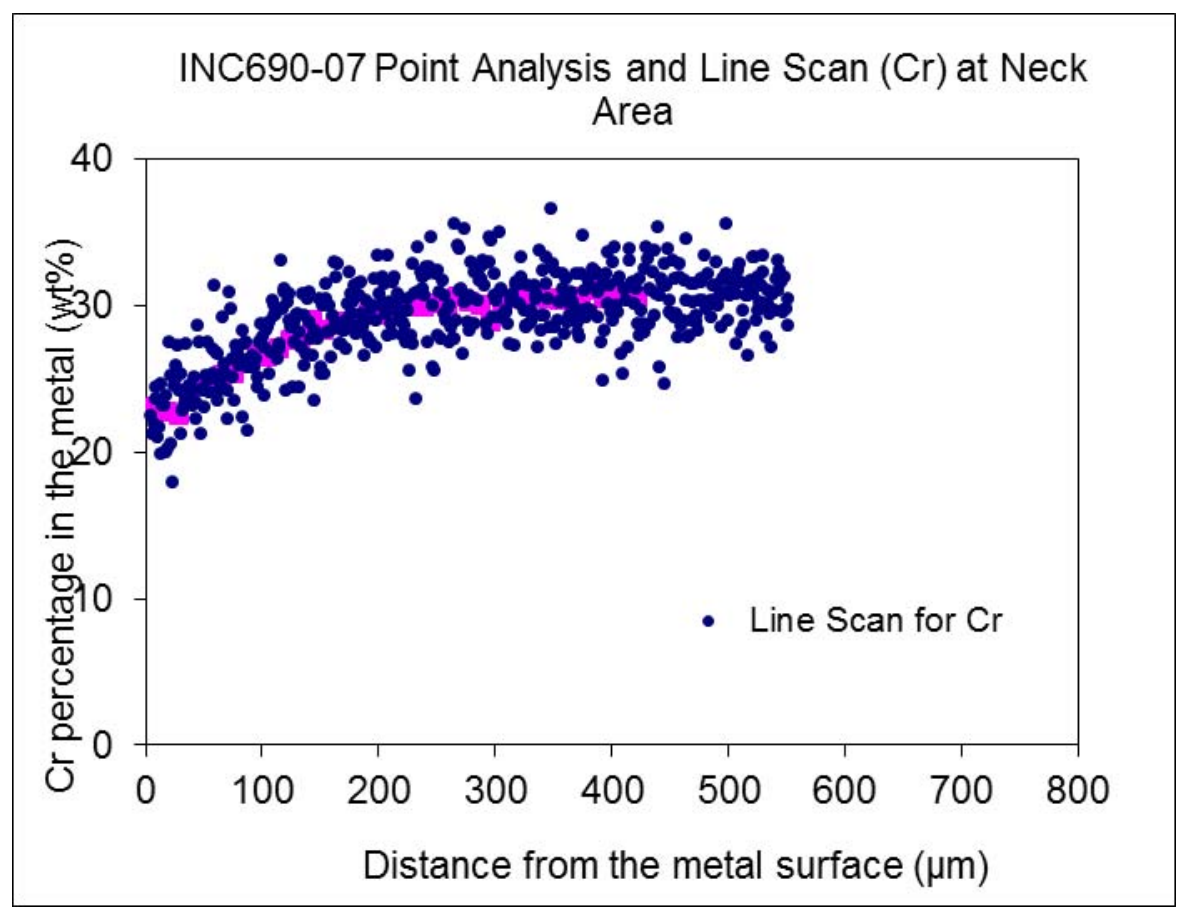

a) Inconel 690 in neck area (square symbols in magenta are by point analysis)

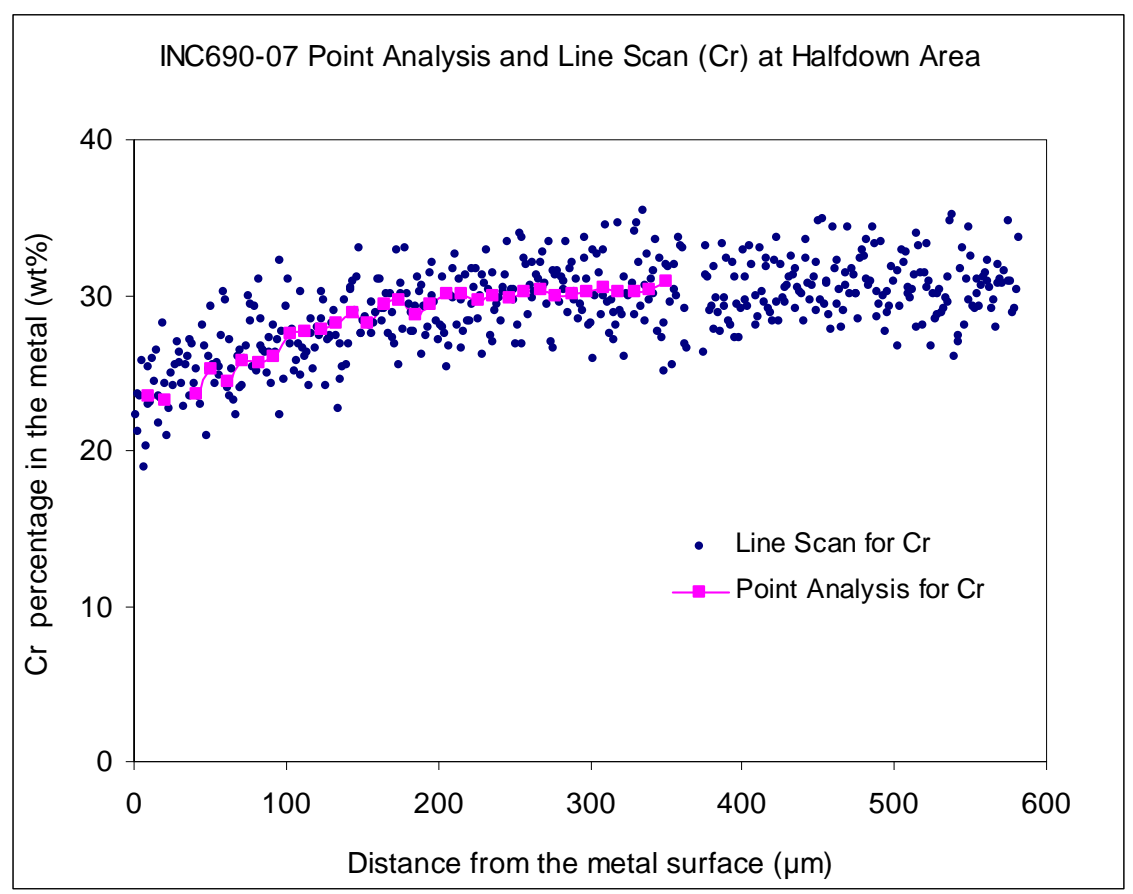

b) Inconel 690 in half-down area

Figure 3.17. SEM/EDS analysis of Cr depletion near surface of Inconel 690 after 7-day sealed crucible corrosion test in HLWS-27 at $1150^{\circ} \mathrm{C}$. 


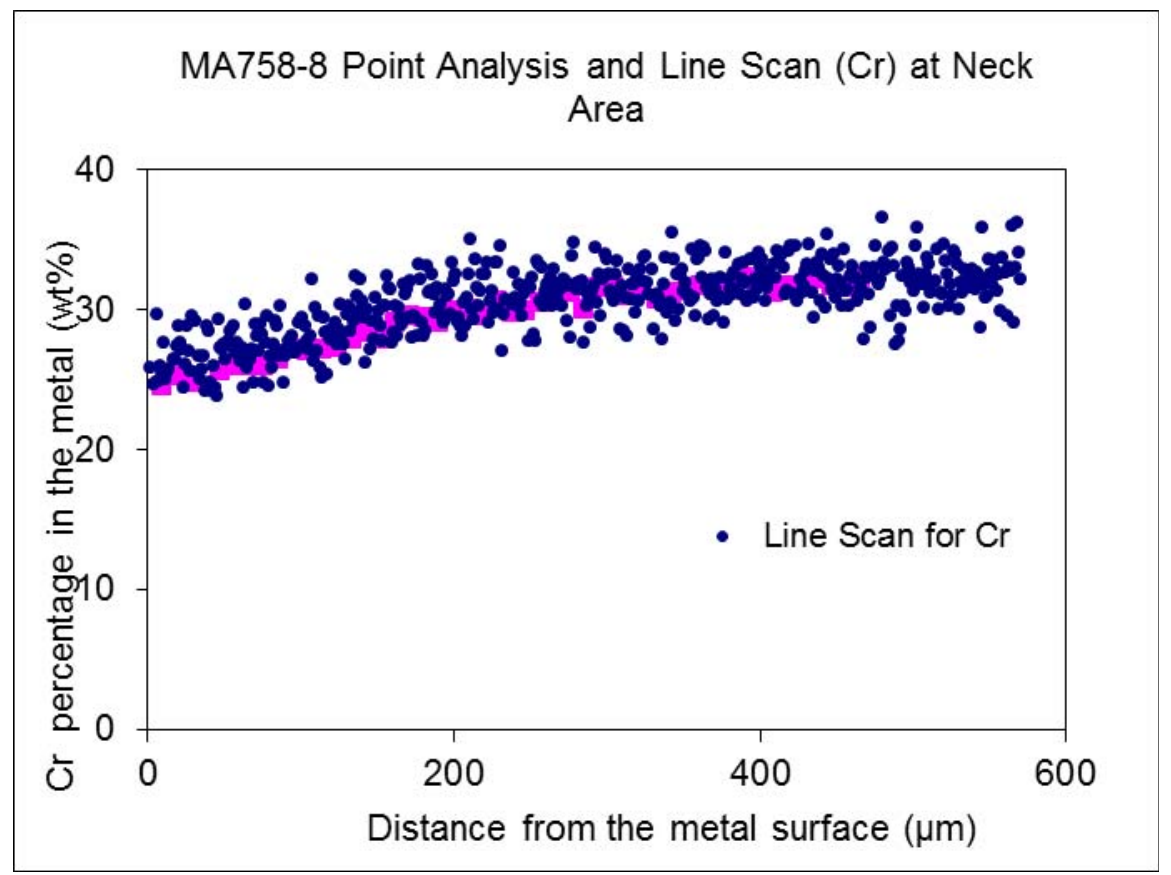

a) MA758 in neck area (square symbols in magenta are by point analysis)

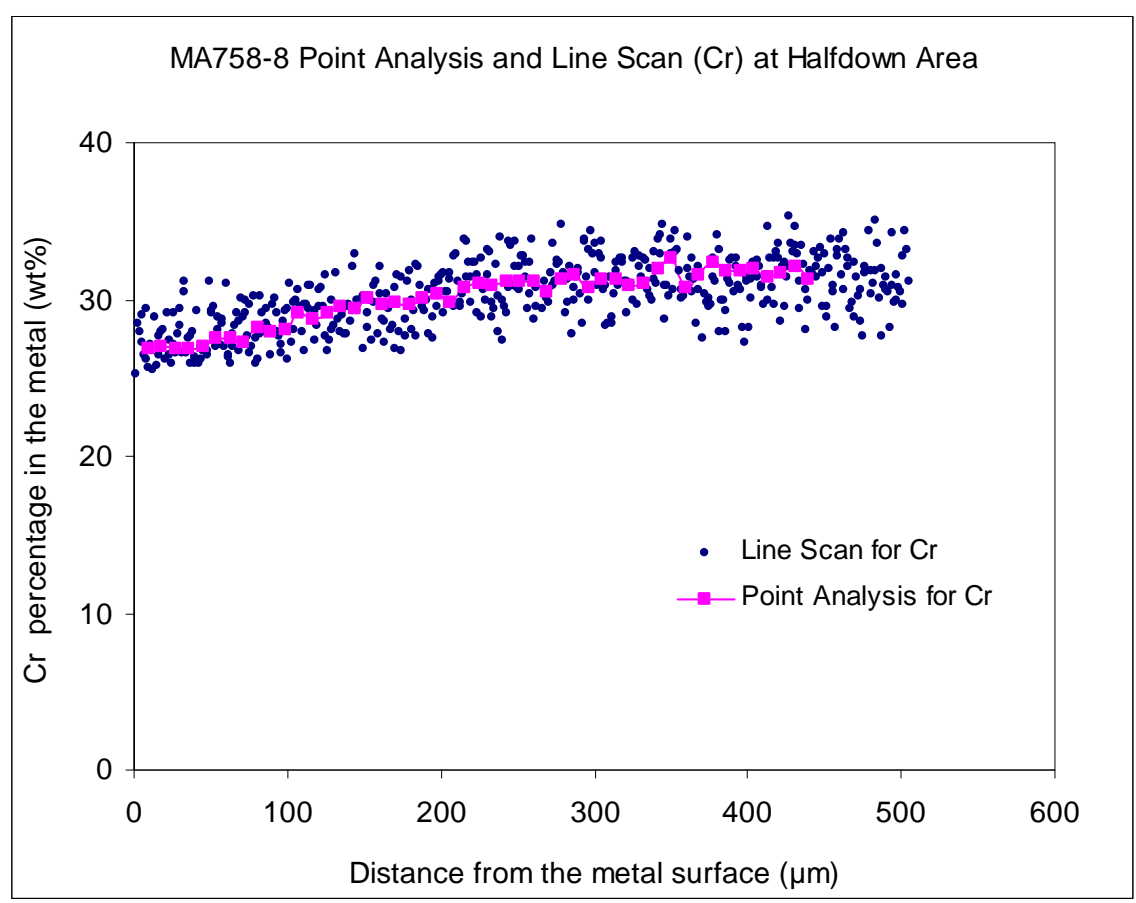

b) MA758 in half-down area

Figure 3.18. SEM/EDS analysis of Cr depletion near surface of MA758 after 7-day sealed crucible corrosion test in HLWS-27 at $1150^{\circ} \mathrm{C}$. 


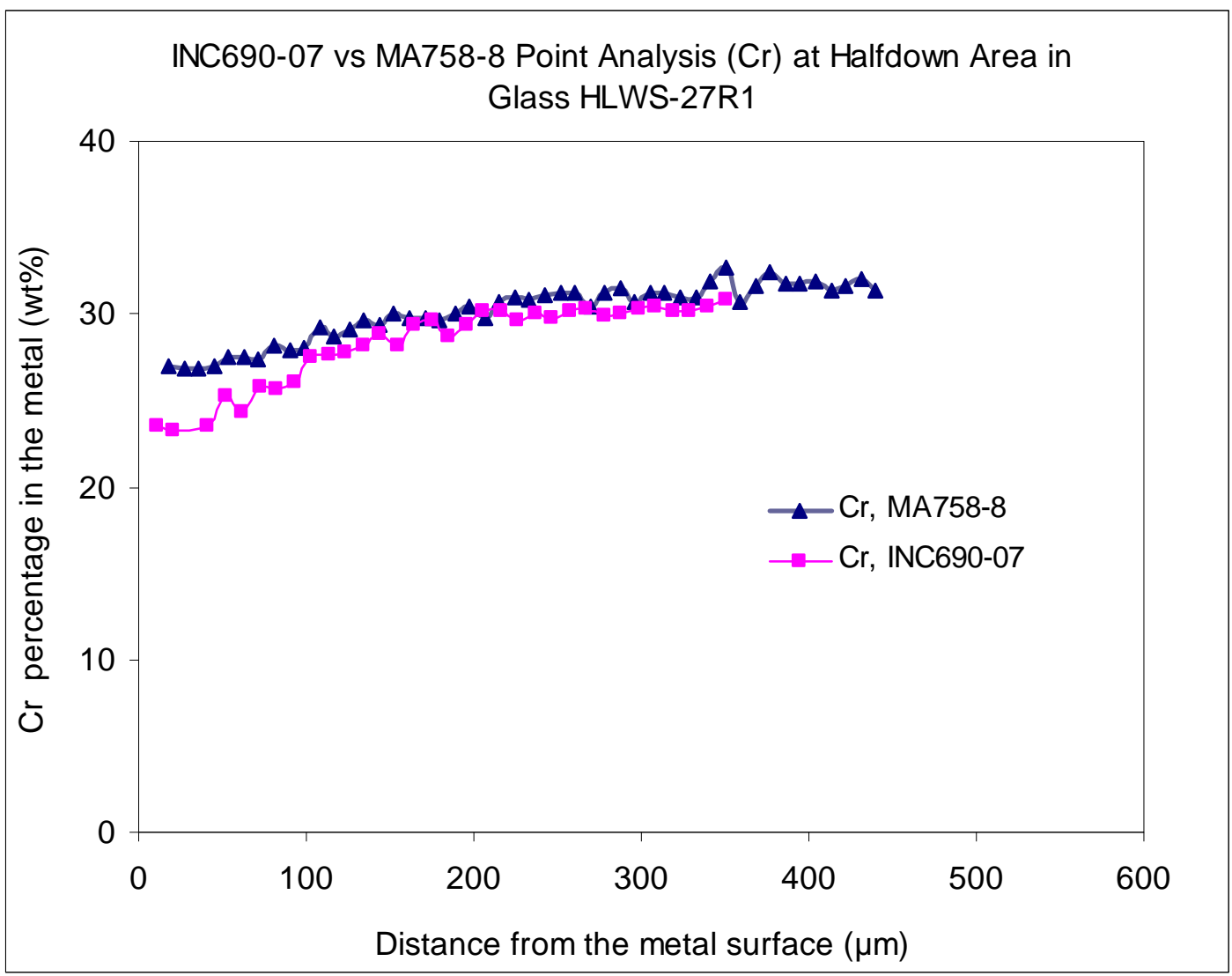

Figure 3.19. Comparison of $\mathrm{Cr}$ depletion at half down areas after 7-day corrosion tests in HLWS-27 in sealed crucibles for MA758 (black triangles) and for Inconel 690 (magenta squares). 


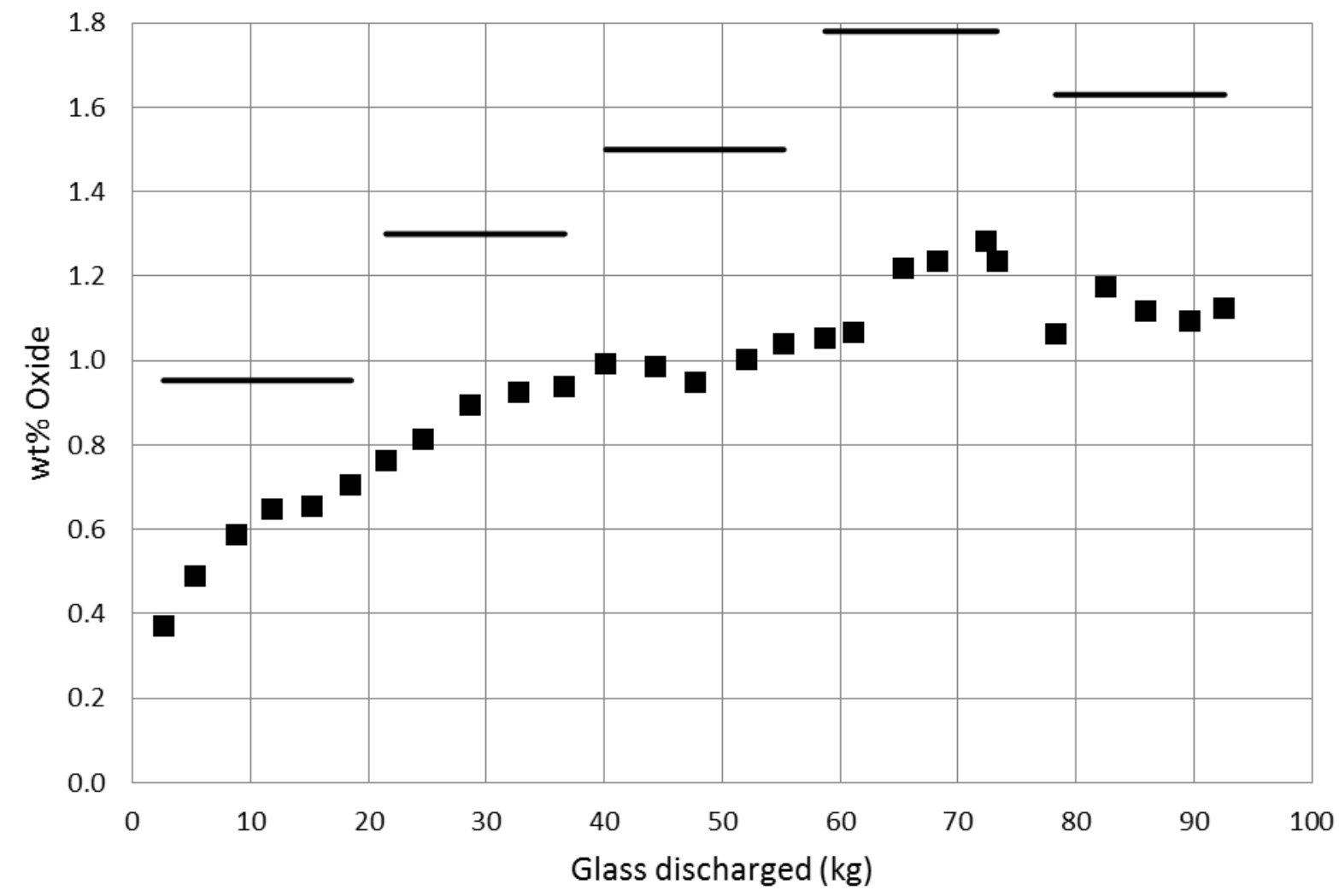

- Measured $\mathrm{SO} 3 \longrightarrow$ Target $\mathrm{SO} 3$

Figure 4.1. XRF measured product and target glass sulfur concentrations while processing the HLWS-27 glass formulation. 


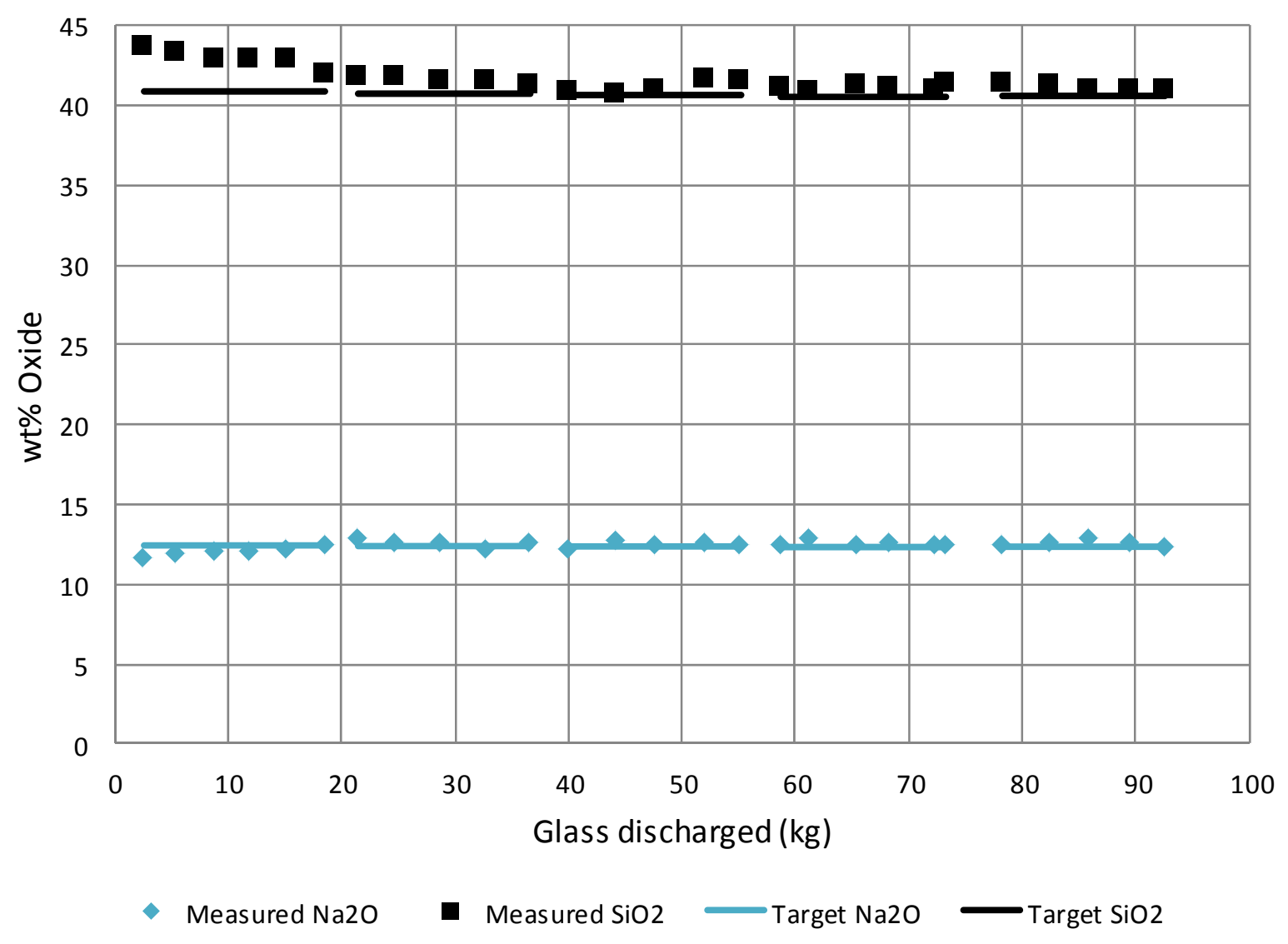

Figure 5.1. XRF measured product and target glass soda and silica concentrations. 
ORP-56310 Rev. 0

The Catholic University of America

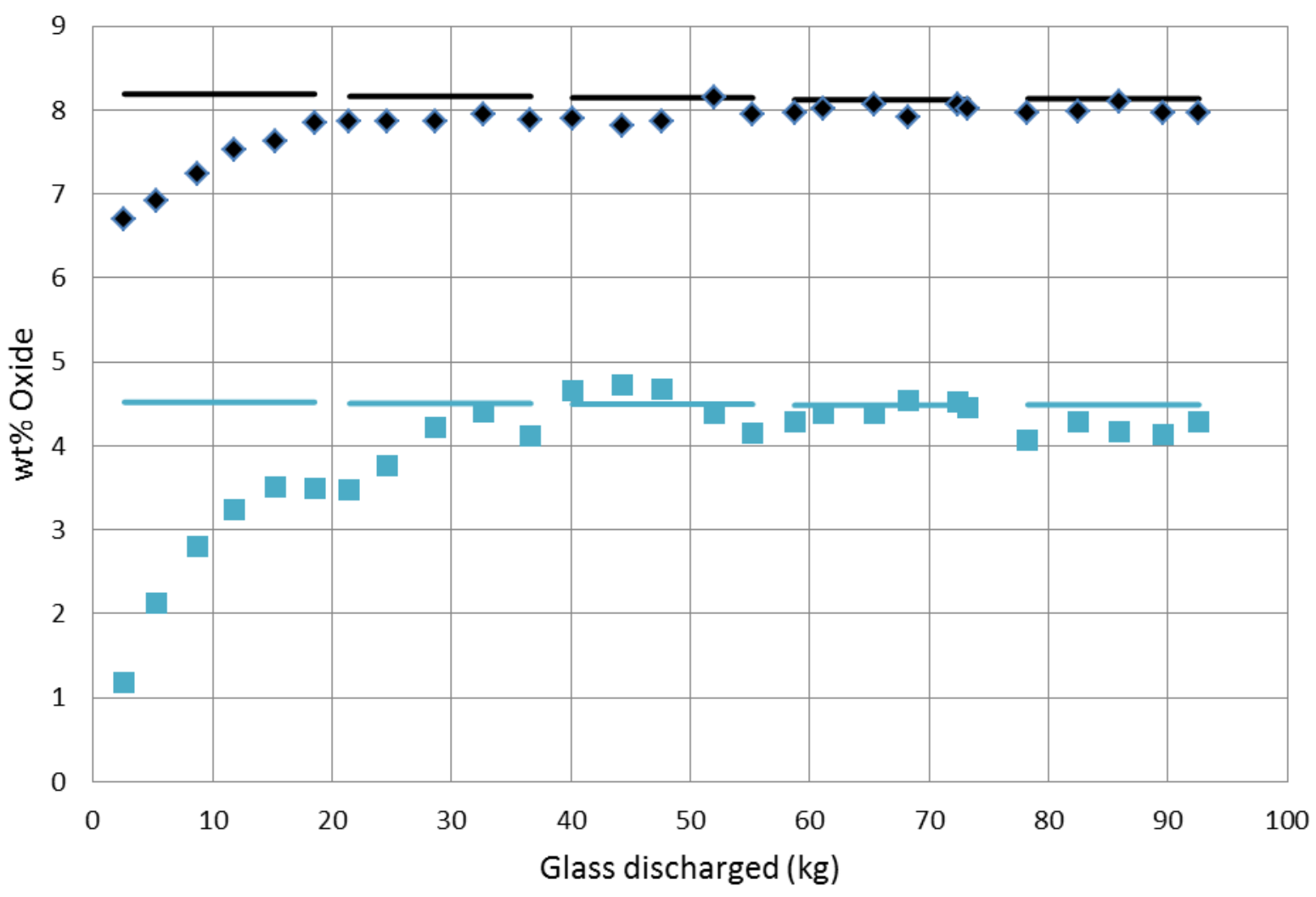

- Measured Al2O3 Measured MnO Target Al2O3 - Target MnO

Figure 5.2. XRF measured product and target glass aluminum and manganese oxide concentrations. 


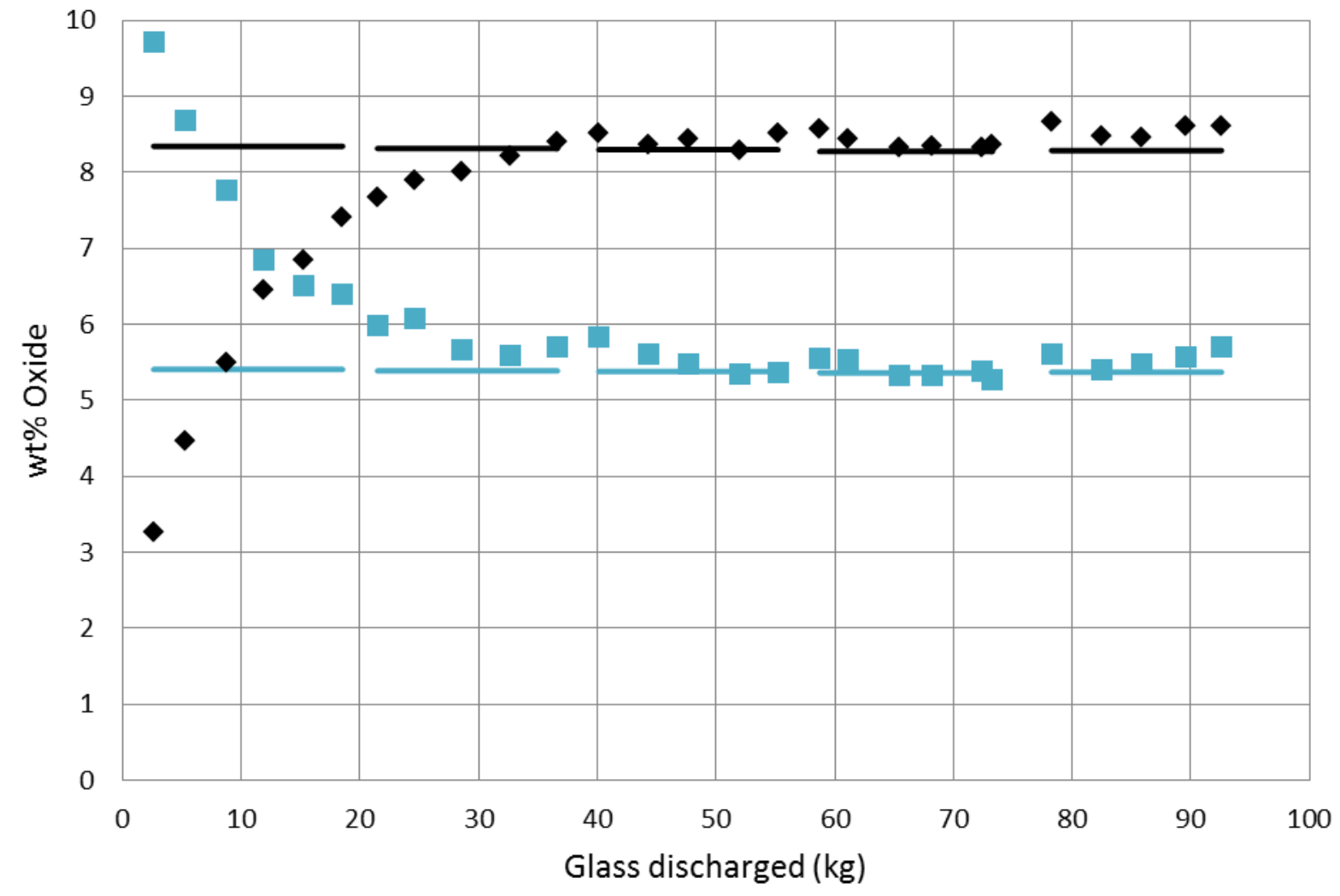

- Measured $\mathrm{CaO}$ - Measured Fe2O3 Target $\mathrm{CaO}$ Target Fe2O3

Figure 5.3. XRF measured product and target glass calcium and iron oxide concentrations. 


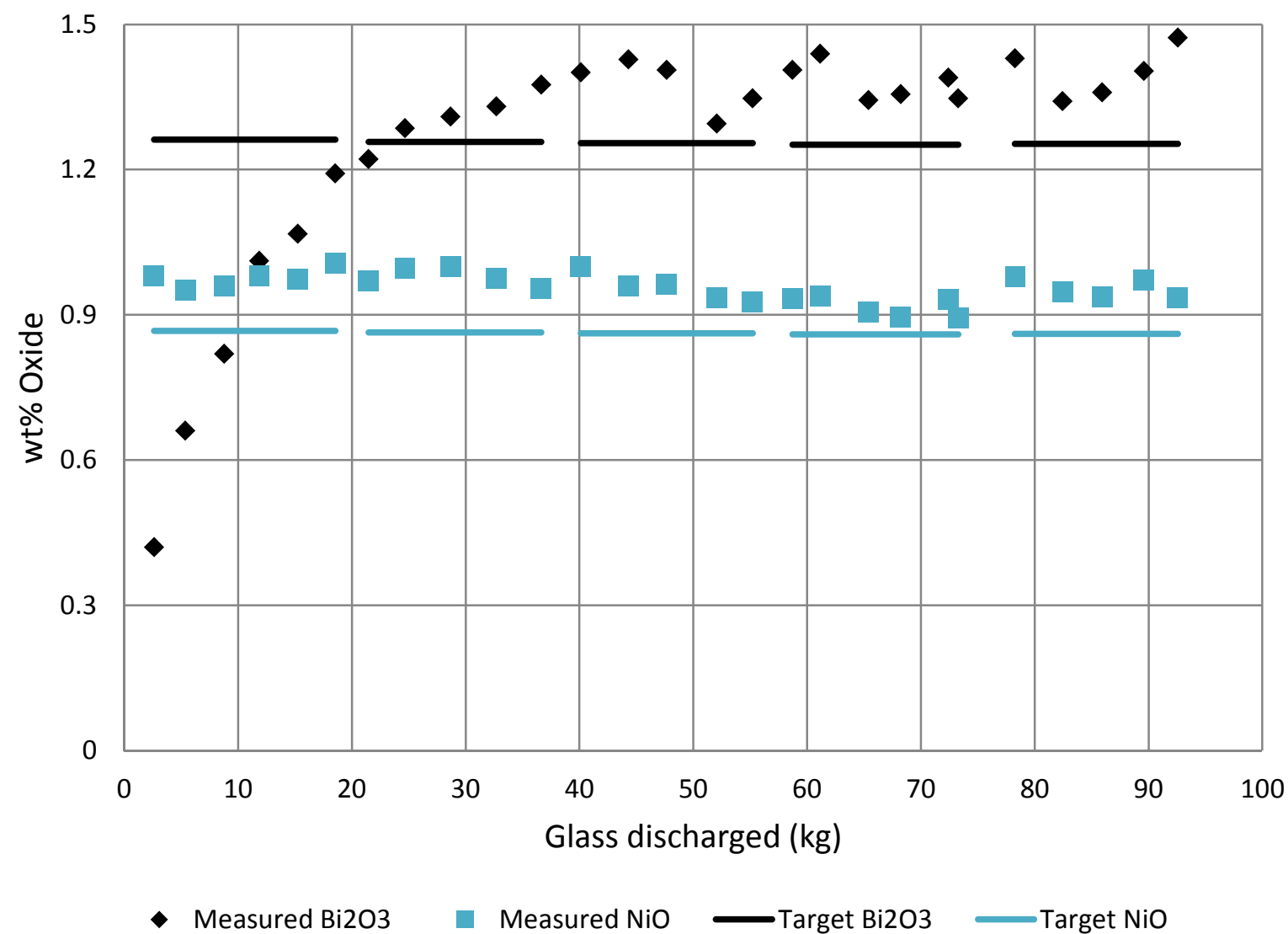

Figure 5.4. XRF measured product and target glass bismuth and nickel oxide concentrations. 


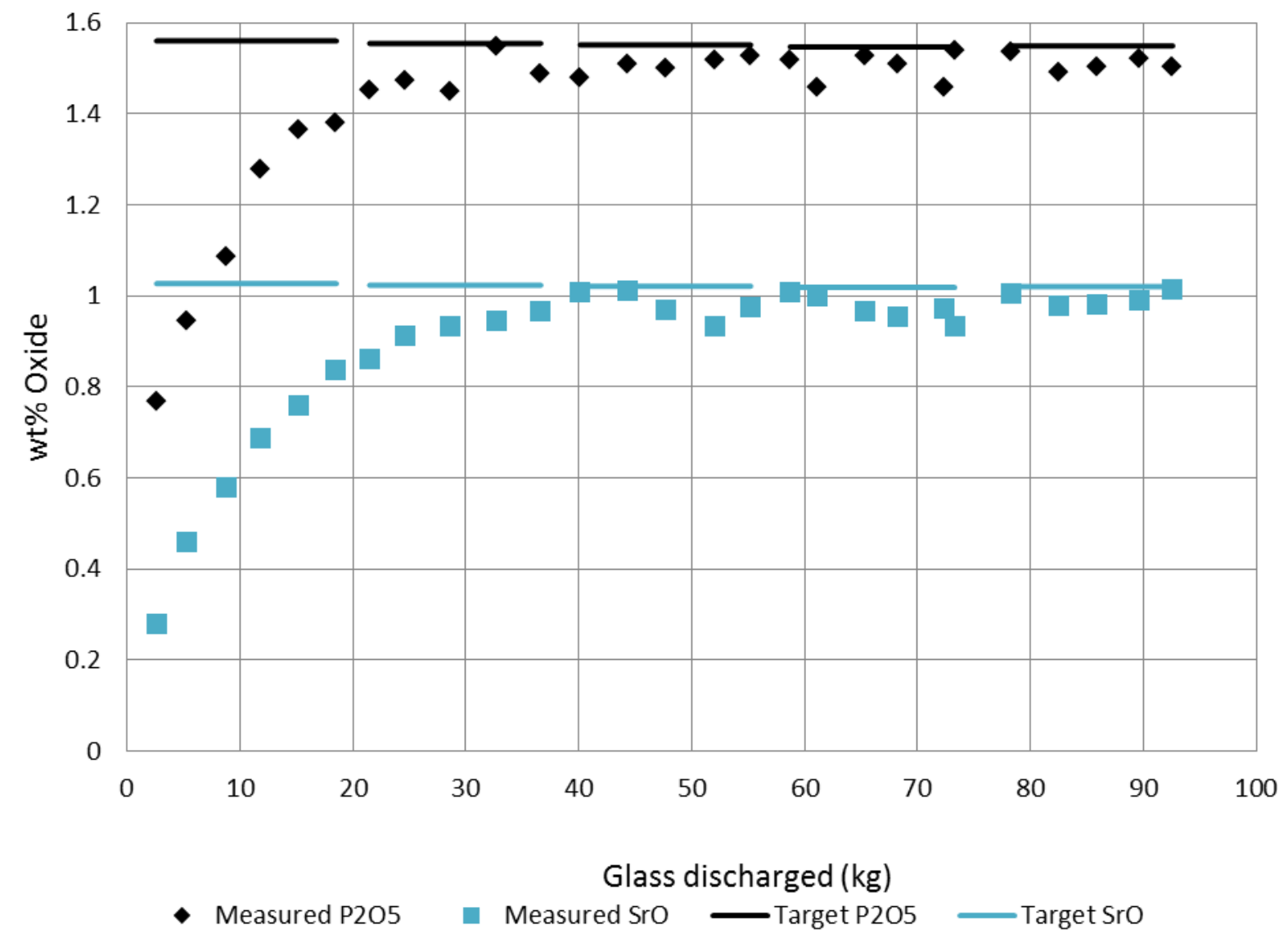

Figure 5.5. XRF measured product and target glass phosphorus and strontium oxide concentrations. 


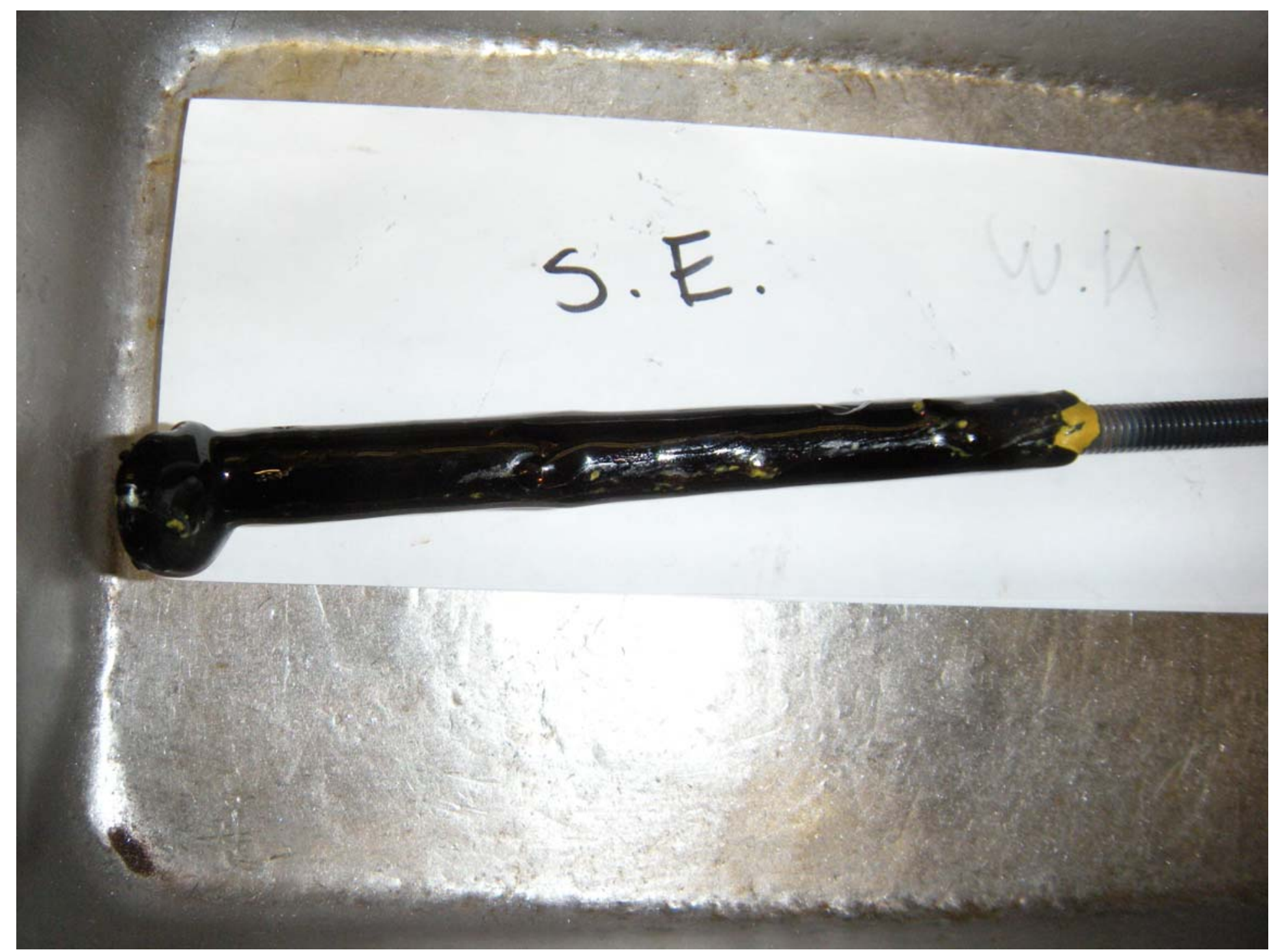

Figure 5.6(a). Secondary phase observed on dip sample, D-10B-67C, taken after Test $2 \mathrm{D}$. 


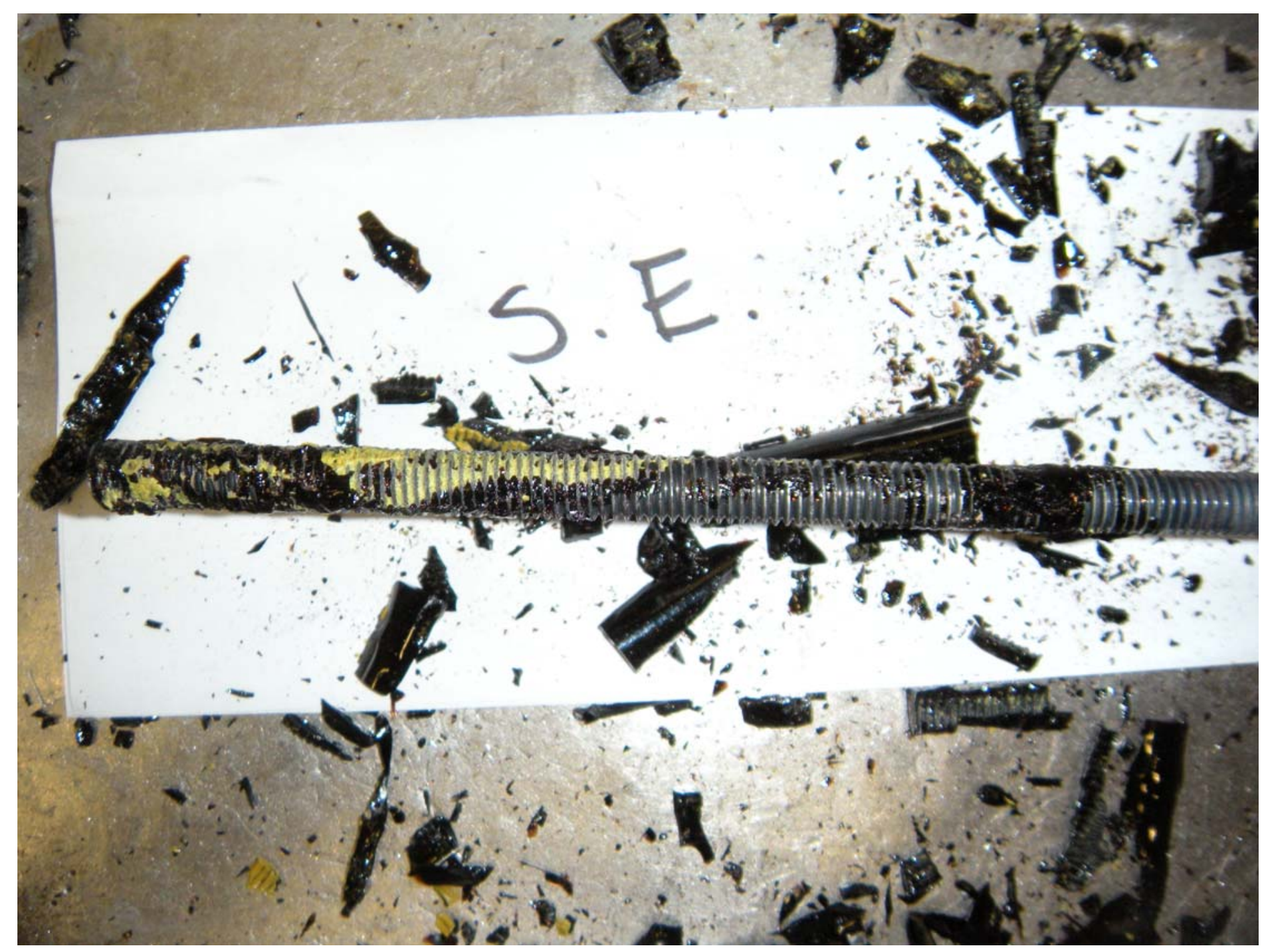

Figure 5.6(b). Secondary phase observed on dip sample, D-10B-67C, taken after Test 2D. 


\section{Appendix A}

\section{Plots of Heat Treatment Data and Regressions}

This appendix presents heat treatment data collected for the HLWS- series of glasses. For each of the HLWS- glasses, the volume \% crystallinity data measured after heat treatment are plotted against the heat treatment temperature (heat treatment time $=70$ hours, after 1 hour at $\left.1200^{\circ} \mathrm{C}\right) . \mathrm{T}_{1} \%$ values were estimated from linear regression of the heat treatment data. 
The Catholic University of America

Vitreous State Laboratory

HLWS-21

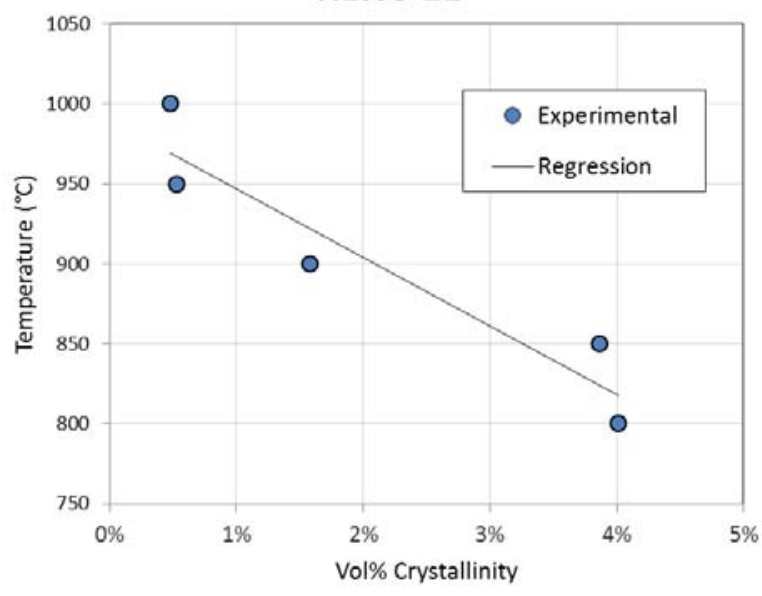

HLWS-23

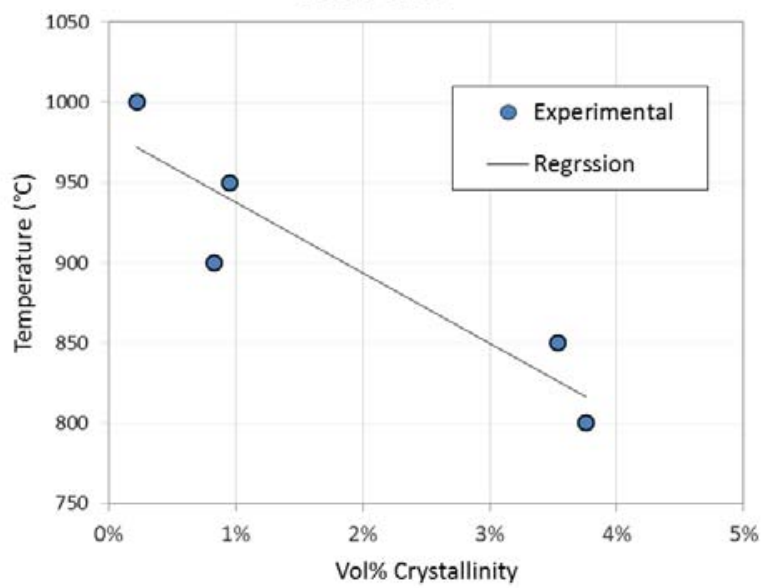

Management of High Sulfur HLW Final Report, VSL-13R2920-1, Rev. 0

HLWS-22

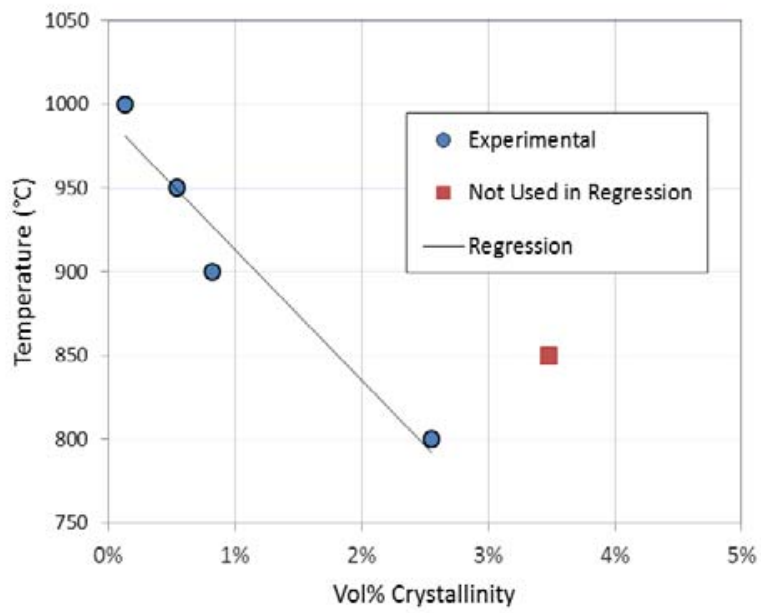

HLWS-24

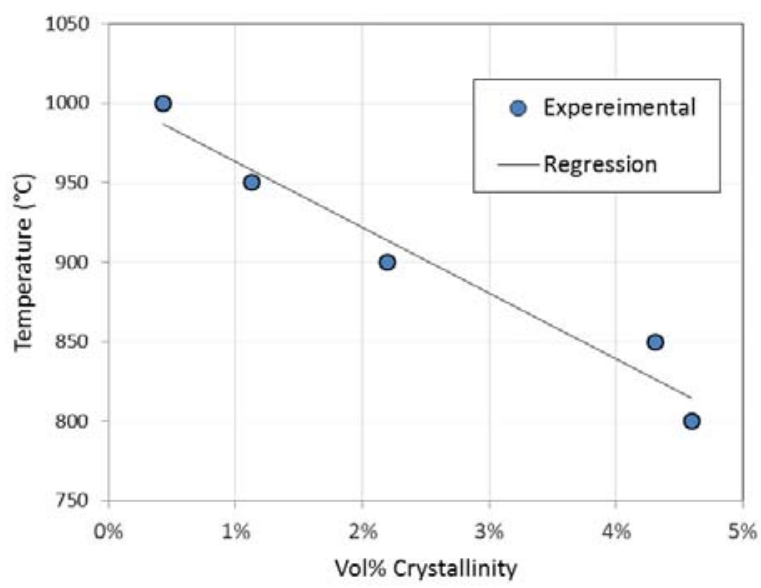


The Catholic University of America

Vitreous State Laboratory

HLWS-25

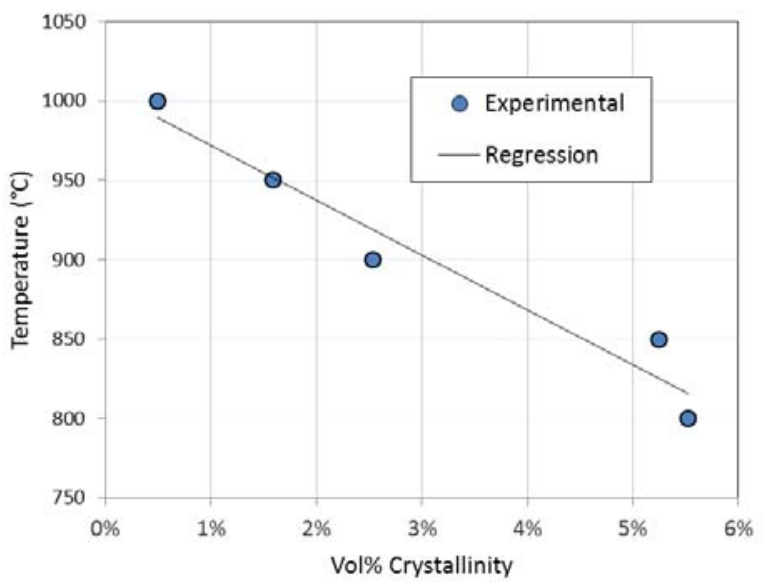

HLWS-27

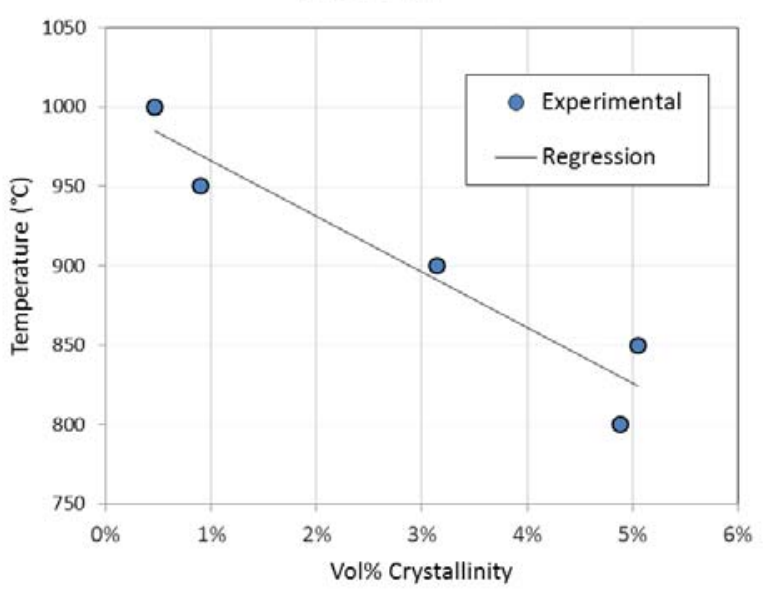

Management of High Sulfur HLW Final Report, VSL-13R2920-1, Rev. 0
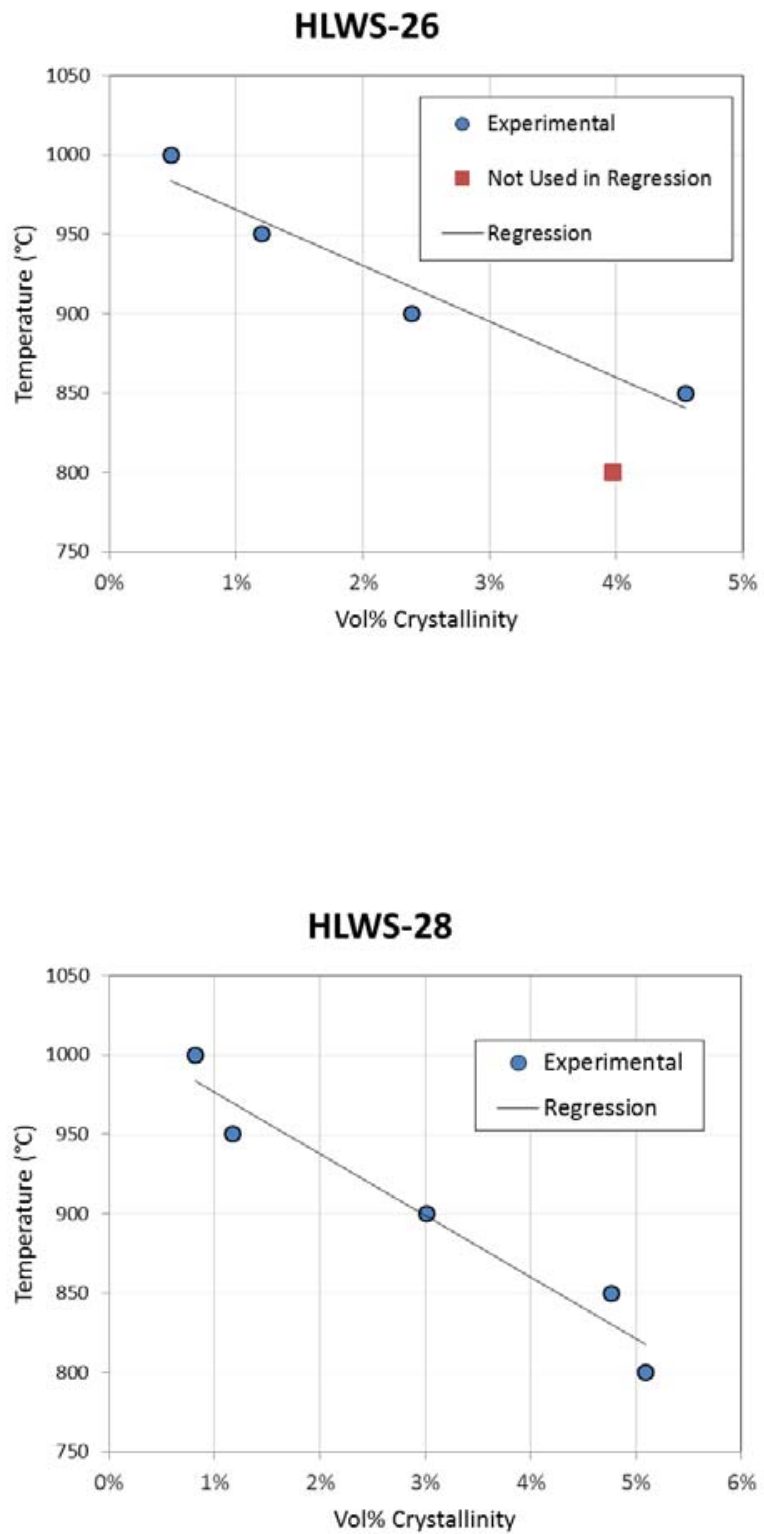
The Catholic University of America Vitreous State Laboratory

HLWS-29

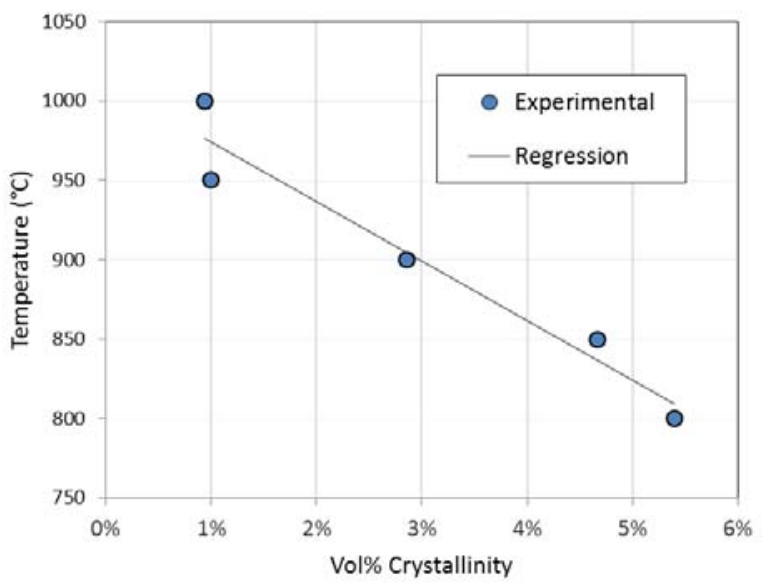

HLWS-31

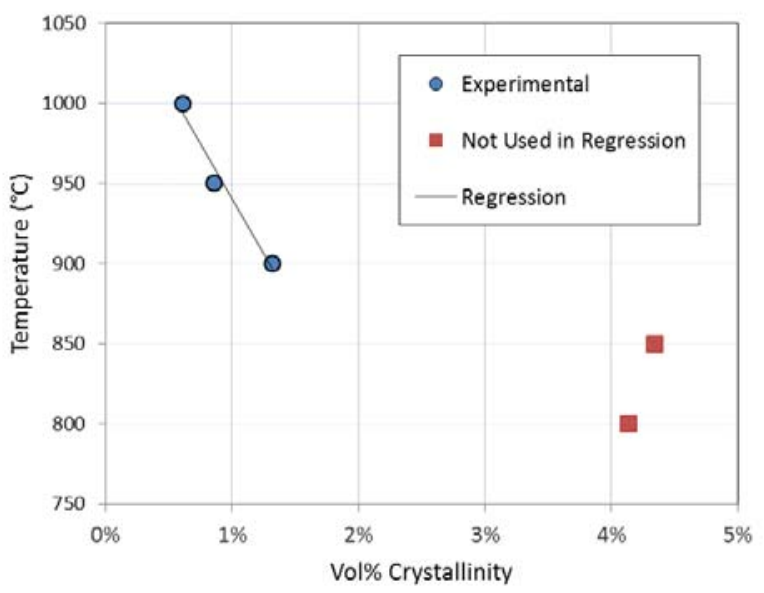

Management of High Sulfur HLW Final Report, VSL-13R2920-1, Rev. 0

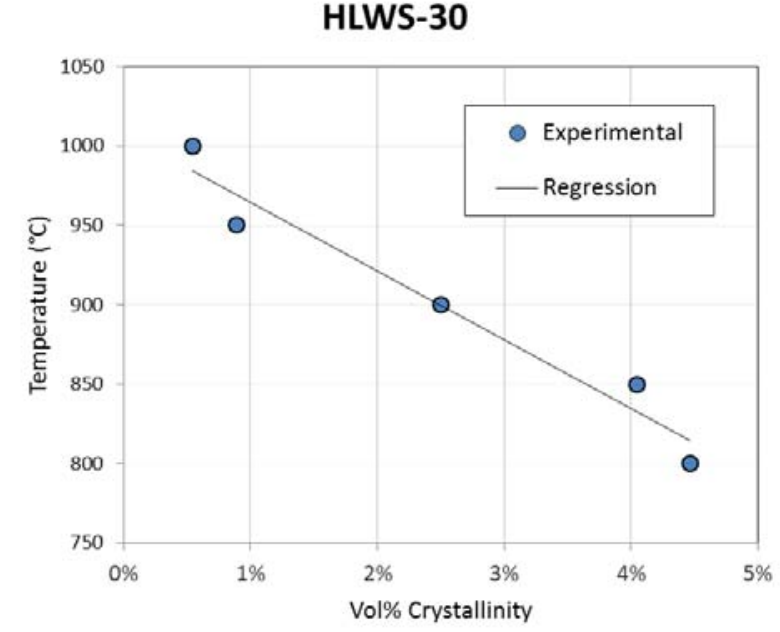

HLWS-32

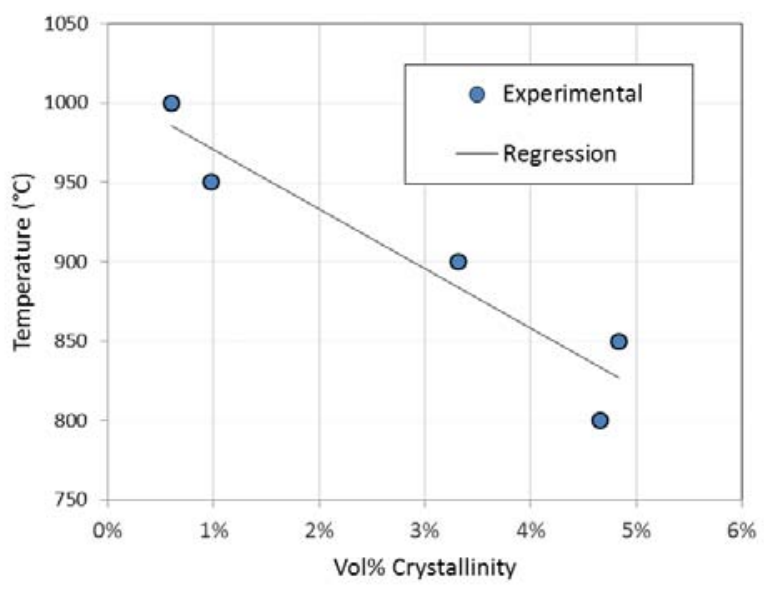


ORP-56310 Rev. 0

The Catholic University of America

Management of High Sulfur HLW Vitreous State Laboratory

Final Report, VSL-13R2920-1, Rev. 0

HLWS-33

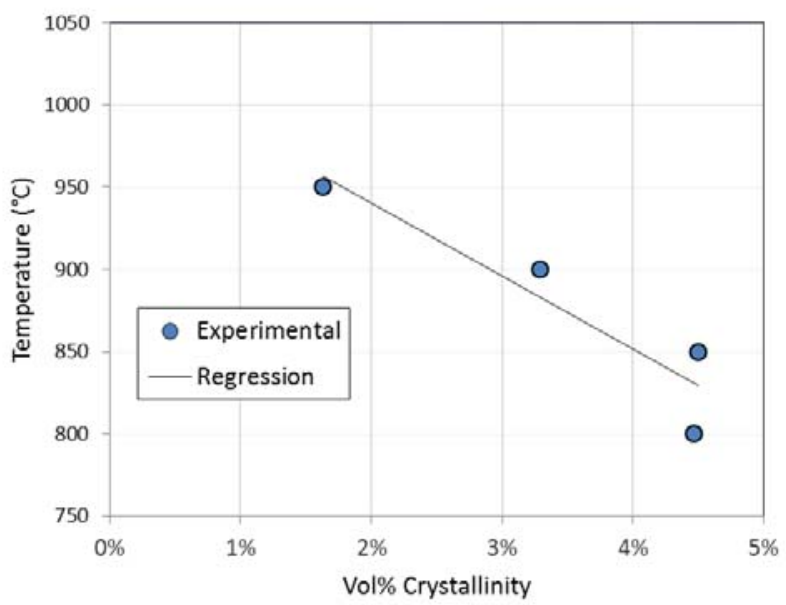

